\title{
Predição de RNAs não codificantes e sua aplicação na busca do componente RNA da telomerase
}

\author{
ARIANE MaChado Lima
}

\author{
TESE APRESENTADA \\ $\mathrm{AO}$ \\ PROGRAMA INTERUNIDADES DE BIOINFORMÁTICA \\ DA \\ UNIVERSIDADE DE SÃO PAULO \\ PARA \\ OBTENÇÃO DO GRAU DE DOUTORA \\ EM \\ BIOINFORMÁTICA
}

\author{
Curso: Doutorado em Bioinformática \\ Instituição: Universidade de São Paulo \\ Orientador: Prof. Dr. Alan Mitchell Durham \\ Co-orientador: Prof. Dr. Hernando A. del Portillo
}

Durante a elaboração deste trabalho a autora recebeu apoio financeiro da Capes

— São Paulo, SP — Novembro de 2006 



\section{Predição de RNAs não codificantes \\ e sua aplicação na busca \\ do componente RNA da telomerase}

Este exemplar corresponde à redação final da tese devidamente corrigida e defendida por Ariane Machado Lima e aprovada pela comissão julgadora.

São Paulo, Janeiro de 2007

\section{Banca examinadora:}

Prof. Dr. Alan Mitchell Durham (orientador)

Prof. Dr. Sérgio Verjóski de Almeida

Profa. Dra. Ângela Kaysel Cruz

Prof. Dr. Alejandro César Frery Orgambide

Profa. Dra. Ana Tereza Ribeiro de Vasconcelos
IME-USP

IQ-USP

FMRP-USP

UFAL

LNCC 

A Deus, o Maior dos Cientistas, que ilumina meu caminho e aquece meu coração. 



\section{Prefácio}

Fiz graduação e mestrado em Ciência da Computação, no Instituto de Matemática e Estatística da Universidade de São Paulo. Meu mestrado, no entanto, foi orientado para aplicações de Bioinformática. Meu orientador de mestrado foi o Prof. Dr. Alan Mitchell Durham. Duas de suas especialidades são Linguagens Formais e Desenvolvimento de Software. Linguagens formais, em particular, é uma área de pesquisa de modelagem e reconhecimento de seqüências em geral, onde gramáticas é um dos alvos de estudo. Com o tema "Laboratório de geração de classificadores de seqüências biológicas", meu trabalho de dissertação foi a respeito do uso de gramáticas livres de contexto estocásticas na caracterização de seqüências e estruturas secundárias de RNAs.

O Prof. Dr. Hernando A. del Portillo é Professor do Instituto de Ciências Biomédicas da Universidade de São Paulo. Durante os anos de 1997 a 1999, orientou a aluna Lindsay Ann Pirrit em sua tese de doutorado "Caracterização dos telômeros e da telomerase de Plasmodium falciparum". Neste trabalho, o tamanho e a estrutura dos telômeros de várias espécies e cepas de Plasmodium foram caracterizados. A atividade telomerase em Plasmodium falciparum foi descrita em vários estágios intra-eritrocíticos do parasita, e a parte proteica da enzima foi isolada. No entanto, as tentativas para identificar o componente RNA foram frustradas.

Através da cooperação entre os Professores Alan e Hernando, nasceu a proposta de uma abordagem bioinformata para a identificação do componente RNA da telomerase em Plasmodium falciparum. Com o nascimento do programa interunidades de Doutorado em Bioinformática da Universidade de São Paulo, tive o privilégio de trabalhar nesse tema como aluna da primeira turma do programa, tendo como orientador o Prof. Dr. Alan M. Durham e como co-orientador o Prof. Dr. Hernando A. del Portillo. 



\section{Agradecimentos}

Aos meus dois orientadores, Prof. Dr. Alan Mitchell Durham e Prof. Dr. Hernando del Portillo, dois excelentes pesquisadores, professores e amigos, com os quais tive o privilégio de aprender muito. Em especial agradeço ao Prof. Alan, por me agüentar por 9 anos consecutivos e por ter me apresentado à bioinformática, e ao Prof. Hernando, por todo o incentivo e por me ensinar o lado "bio" de ser. Adorei trabalhar com vocês!

Ao Dr. Sean R. Eddy, por me receber em seu laboratório em Saint Louis, onde passei seis meses maravilhosos de aprendizado e amadurecimento, pela atenção dispensada, por discussões importantes para a realização deste trabalho, e por disponibilizar uma infra-estrutura computacional (cluster de 128 máquinas) onde foram realizados muitos dos testes descritos neste trabalho.

À Elena Rivas, amiga e pesquisadora maravilhosa, pela amizade e incentivo. A todo o "SELab", especialmente, Eric Nawrocki, por várias discussões produtivas sobre RNAs e a ferramenta INFERNAL.

Ao Mauro Ferreira de Azevedo e ao Márcio Massao Yamamoto, por terem realizado os experimentos biológicos e auxiliado nos "experimentos etílicos".

Ao grupo de estudos "durham-queridinhos" e ao laboratório de Malária, pelas discussões, seminários e cervejas.

Ao Programa de Bioinformática da USP, em primeiro lugar por existir (pois me apaixonei por Bioinformática), e também pelo grande apoio que recebi através da Profa. Dra. Helaine, presidente da CPG. À Patrícia, que sempre se desdobra para nos tirar de apuros.

Aos meus pais, João e Yolanda, que sempre me apoiaram para eu ser o que eu quisesse... mesmo que fosse uma cientista maluca... Aos meus irmãos, Bão e Caiá, cunhadas Déia e Eli e sobrinhas lindas, Fabi, Luiza e Mariana, que tenham chegados os dias nos quais eu poderei estar um pouco mais perto de vocês.

Ao meu querido, paciente, compreensivo, lindo e amado marido, Fernando, por tanto apoio e admiração pelo meu trabalho, o que me inspira a ser melhor a cada dia, como profissional e como pessoa. Eu te amo!

A amigos tão queridos Selma (sempre companheira) e Sandrão (sempre mandando eu "quebrar tudo").

E, como não poderia deixar de agradecer, AOS ADMINS DA REDE VISION (todos eles, mas em especial ao David que é também um amigão) sem os quais esse trabalho seria realmente

\section{INFERNAL!!!}





\section{Resumo}

RNAs não codificantes (ncRNAs) têm ganho crescente prestígio nos últimos anos devido a recentes e contínuas descobertas revelando sua diversidade e importância. Porém, a identificação dessas moléculas ainda é um problema em aberto. Em particular, Plasmodium falciparum é um desafio para a pesquisa de ncRNAs, onde poucos foram identificados até o momento. P. falciparum é o parasita que causa uma malária humana letal. A descoberta de novos ncRNAs neste organismo pode auxiliar no desenvolvimento de novos tratamentos. Este trabalho faz um estudo sobre técnicas computacionais para a predição de ncRNAs e, utilizando como objeto de estudo $P$. falciparum, propõe uma metodologia de predição que seja aplicável inclusive a genomas com viés composicional. A ênfase deste estudo foi a predição de ncRNAs família-específicos, utilizando o componente RNA da telomerase como objeto de estudo. Este é um importante RNA que, devido à sua alta taxa de mutação, é de difícil identificação. Este RNA ainda não foi identificado em $P$. falciparum. No entanto, evidências biológicas indicam que este RNA é presente, funcional e deve ser essencial ao parasita, caracterizando-se como um alvo de drogas. Além disso, foi realizado um trabalho preliminar sobre a predição de ncRNAs em geral em $P$. falciparum utilizando uma abordagem comparativa.

\section{Abstract}

Noncoding RNAs (ncRNAs) have been receiving increasing prestige in the last years due to recent and continuous discoveries revealing their diversity and importance. However, the identification of these molecules is still an open problem. In particular, Plasmodium falciparum is a challenge for the ncRNA research, in which few ncRNAs have been identified. P. falciparum is the parasite that causes a lethal human malaria. The discovery of new ncRNAs in this organism may help in the development of new treatments. This work does a research of computational techniques for the ncRNA prediction and, by using P. falciparum as target, proposes a prediction methodology which is also applicable to compositionally biased genomes. The emphasis of this study was the prediction of family-specific ncRNAs, by using the telomerase RNA component as target. This is an important RNA that has a high mutation rate, being difficult to predict. This RNA has not been identified in P. falciparum, yet. However, biological evidences indicate this RNA is present, functional and might be essential for the parasite, being a drug target. In addition, this work presents preliminary results about the prediction of general ncRNAs in $P$. falciparum by using a comparative approach. 



\section{Índice}

1 Introdução $\quad 1$

1.1 RNAs não codificantes . . . . . . . . . . . . . . . . . . . 1

1.2 Plasmodium falciparum e RNAs não codificantes . . . . . . . . . . . . 5

$1.3 \mathrm{O}$ componente RNA telomerase . . . . . . . . . . . . . . . . 6

1.3.1 Os telômeros e sua manutenção . . . . . . . . . . . . . . . . . 7

1.3 .2 Atividade telomerase . . . . . . . . . . . . . . . . 9

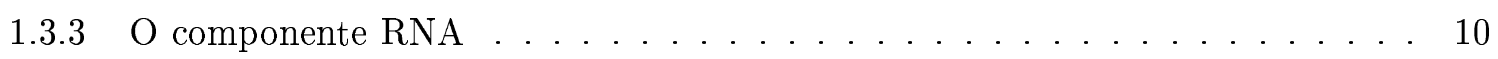

1.3.4 Telomerase em Plasmodium falciparum . . . . . . . . . . . . . . . . 12

1.3.5 TERC em P. falciparum como objeto de estudo . . . . . . . . . . . . . . 13

1.4 Objetivo . . . . . . . . . . . . . . . . . . . . . . . . 13

1.5 Sobre a organização do trabalho . . . . . . . . . . . . . . . . . 13

2 Métodos computacionais na pesquisa de ncRNAs $\quad 15$

2.1 Definição formal de estrutura secundária . . . . . . . . . . . . . . . . 16

2.2 Problemas e abordagens gerais na pesquisa de ncRNAs $\ldots \ldots \ldots$

2.2.1 Três principais problemas . . . . . . . . . . . . . . . 16

2.2 .2 Três principais abordagens . . . . . . . . . . . . . . . 17

2.3 Predição de estrutura secundária . . . . . . . . . . . . . . . . . . . 19

2.3.1 Métodos ab initio: predição de uma única seqüência . . . . . . . . . . . 19

2.3 .2 Método comparativos . . . . . . . . . . . . . . 25

2.4 Comparação estrutural . . . . . . . . . . . . . . . . . . . . 34

2.4.1 Utilização de árvores e seqüências de parênteses . . . . . . . . . . . . . . 35

2.4 .2 Utilização de grafos . . . . . . . . . . . . . . . . . . . 35

2.4.3 Utilização de todo o espaço de estruturas . . . . . . . . . . . . . . . . 36 
2.5 Identificação de RNAs não codificantes . . . . . . . . . . . . . . . . . . . 37

2.5.1 Detectores gerais de genes de ncRNAs . . . . . . . . . . . . 37

2.5.2 Detectores de genes de ncRNAs baseados em um conjunto de seqüências conhecidas . . . . . . . . . . . . . . . . . . . . . . . 40 40

2.5.3 Detectores de genes de famílias específicas de ncRNAs . . . . . . . . . . . . 42

3 Busca de ncRNAs em Plasmodium falciparum 45

3.1 Métodos . . . . . . . . . . . . . . . . . . . . . 47

3.1.1 Construção de alinhamentos entre $P$. falciparum e P. yoelii . . . . . . . . . 47

3.1 .2 Análise dos alinhamentos . . . . . . . . . . . . . . . 51

3.2 Resultados . . . . . . . . . . . . . . . . . . . . . 51

4 Análises e buscas preliminares de TERCs

4.1 Aproximação heurística e termodinâmica . . . . . . . . . . . . . . . . 53

4.1 .1 Análise de TERCs . . . . . . . . . . . . . . . . . . . . 54

4.1.2 Busca no genoma do Plasmodium falciparum e ordenação preliminar . . . . . 59

4.2 Análise gramatical . . . . . . . . . . . . . . . . . 6 . 63

4.2 .1 Métodos . . . . . . . . . . . . . . . . . . . . . 64

4.2 .2 Resultados . . . . . . . . . . . . . . . . . . . . 72

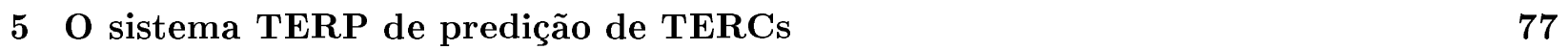

5.1 INFERNAL . . . . . . . . . . . . . . . . . . . . . . . . . . . . 79

5.1 .1 Modelos de Covariância . . . . . . . . . . . . . . . . . 80

5.1 .2 Sistema de escore . . . . . . . . . . . . . . . . . . . . 82

5.2 Estudo de um modelo nulo adequado . . . . . . . . . . . 85

5.3 Métodos . . . . . . . . . . . . . . . . . . . . . . . . . . 89

5.3 .1 Alinhamentos de TERCs . . . . . . . . . . . . . . . . . 89

5.3 .2 O sistema TERP . . . . . . . . . . . . . . . . . . . . 90

5.3 .3 Testes em vertebrados . . . . . . . . . . . . . . . . . 95

5.3 .4 Aplicação em organismos sem TERC conhecida . . . . . . . . . . . . . . . 96

5.4 Resultados . . . . . . . . . . . . . . . . . . . . . . 97

5.4 .1 Testes em vertebrados $\ldots \ldots \ldots \ldots \ldots \ldots$. . . . . . . . . . . . . . 97

5.4 .2 Aplicação em organismos sem TERC conhecida . . . . . . . . . . . . . . 97

6 Conclusões e trabalhos futuros $\quad 101$

6.1 Conclusões . . . . . . . . . . . . . . . . . . . . . . . . . . . 101 
6.2 Trabalhos futuros . . . . . . . . . . . . . . . . . . 107

$\begin{array}{ll}\text { A Glossário } & 113\end{array}$

$\begin{array}{ll}\text { B Abreviaturas } & 117\end{array}$

C Tabela de programas e serviços WEB para pesquisa de ncRNAs 119 



\section{Lista de Figuras}

1.1 A: Fluxo molecular considerado como o dogma central da biologia. B: Representação esquemática de um novo fluxo molecular emergindo de recentes descobertas (adaptado de [52]). . . . . . . . . . 4

1.2 Componentes estruturais de uma estrutura secundária de RNA. . . . . . . . . . . . . . . . . 5

1.3 Replicação de DNA e fragmentos Okazaki . . . . . . . . . . . . . . . . . . . . . . . . . . . 8

1.4 Processo de síntese telomérica (adaptado de [98]) . . . . . . . . . . . . . . . . . . . . . . . . . . 9

1.5 Estruturas consenso de TERCs de ciliados, vertebrados e leveduras. Figura de [38]. . . . . . . . . 11

2.1 Grafo representando uma estrutura secundária de RNA. Nós são bases e arestas representam pareamentos. Os valores $w 1 \ldots w 6$ são pesos atribuídos às arestas. . . . . . . . . . . . . . . . . . . . . . 24

2.2 Seqüências arco-anotadas e as operações permitidas [130]. . . . . . . . . . . . . . . . . . . . . . . . . 29

3.1 Função de densidade da distribuição de Gumbel estimada para a matriz $S$. Os círculos são as freqüências obtidas para cada escore dos 20.059.453 alinhamentos e a curva é a densidade estimada. 50

3.2 Processo de análise dos alinhamentos. . . . . . . . . . . . . . . . . . . . . . . . . . 52

4.1 Estrutura consenso de TERCs de 3 espécies de Euplotes. Linhas pontilhadas indicam formação de pseudo-nó. Figura adaptada de [158]. . . . . . . . . . . . . . . . . . . . . . . . . . . . . . 58

4.2 Dot-plot de TERC de Euplotes . . . . . . . . . . . . . . . . . . . . . . . . . 60

4.3 Estruturas secundárias preditas pelo mfold. À esquerda TERC de Colpidium; à direita o candidato 12. . . . . . . . . . . . . . . . . . . . . . . 62

4.4 RT-PCR de msp1 e tert (controles positivos) e seqüências 12, 29 e 44 (TERCs candidatos). . . . . 63

4.5 Duas execuções de 5'-RACE. A: Temperatura de $60^{\circ} \mathrm{C}$ de anelamento. B: Uso de três temperaturas de anelamento: $55^{\circ} \mathrm{C}, 60^{\circ} \mathrm{C}$ e $65^{\circ} \mathrm{C}$. . . . . . . . . . . . . . . . . . . . . . . . . 64

4.6 Processo de geração de um classificador . . . . . . . . . . . . . . . . . . . . . . . . . 65

4.7 Estrutura secundária de TERC de Tetrahymena thermophila, apenas a parte definida entre o início e o fim da Hélice I. L1 a L5 indicam cinco regiões de loop. Figura editada de [158]. . . . . . . . . 68 
4.8 NLL escores de seqüências positivas e negativas e curvas $N L L_{m e d}$ e $N L L_{d p} . \quad$. . . . . . . . . . 70

4.9 Gráfico de z-escore de tRNAs para amostra de treinamento de tamanho 500. À esquerda: amostra positiva; no centro: amostra negativa; à direita: amostra de teste. . . . . . . . . . . . . . . . 73

4.10 Gráfico de z-escore de tRNAs sem uso de amostra de treinamento. À esquerda: amostra negativa; à direita: amostra de teste. . . . . . . . . . . . . . . . . . . . . . . . . . . . . . . . . . 73

4.11 Gráfico de z-escore de tRNAs para amostra de treinamento parentisada de tamanho 22. À esquerda: amostra positiva; no centro: amostra negativa; à direita: amostra de teste. . . . . . . . . . . . 74

4.12 Gráfico de z-escore de validação cruzada de TERCs deixando TERCs de Colpidium como amostra de teste. Um limiar de Z-escore $=-3.5$ faz com que a amostra positiva de treinamento tenha 0 falsos negativos, a amostra negativa tenha 0 falsos negativos e que a amostra positiva de teste tenha 0 falsos positivos. . . . . . . . . . . . . . . . . . . . . . . . 74

4.13 Gráfico de z-escore de validação cruzada de TERCs deixando TERCs de Paramecium como amostra de teste. Um limiar de Z-escore $=-4$ faz com que a amostra positiva de treinamento tenha 0 falsos negativos, a amostra negativa tenha 0 falsos negativos e que a amostra positiva de teste tenha 4 falsos positivos (100\%). . . . . . . . . . . . . . . . . . . . . . . . 75

5.1 Alinhamento múltiplo estrutural: o alinhamento é obtido considerando não apenas a seqüência primária como também a estrutura secundária. A última linha representa a estrutura secundária relativa a cada coluna, onde "." representa posições não pareadas e " $<$ " e "> pareados representam um par de posições pareadas. Figura adaptada de [71]

5.2 A: Alinhamento múltiplo estrutural: as caixas indicam as colunas pareadas formando hélices. B: Estrutura consenso obtida do alinhamento da figura A. Colunas com número de gaps superior a $50 \%$ do número de seqüências não participam da estrutura consenso. Figura adaptada de [71]. . . . . .

5.3 Árvore guia do modelo de covariância obtido a partir da estrutura consenso. Estados são representados por retângulos rotulados pelo seu tipo. Triângulos ao lado dos retângulos indicam o sentido (5' ou 3') da emissão de símbolos. A numeração ao lado dos triângulos indica o(s) número(s) da(s) coluna(s) correspondente(s) à emissão, indicadas na figura 5.2. Figura adaptada de [71]. . . . . . .

5.4 Arquitetura completa do modelo de covariância relativo ao trecho destacado da árvore guia (estrutura consenso). Cada estado na árvore guia foi substituído por um conjunto de estados de forma a permitir a identificação de inserções e deleções. . . . . . . . . . . . . . . . . . 8

5.5 A função logística [71] . . . . . . . . . . . . . . . . . . . . . . . . . . . . . . . . . . 85 
5.6 Escores médios de 50 shuffings de cada TERC. A: TERCs de ciliados utilizando alinhamento de ciliados e modelo nulo uniforme; B: TERCs de ciliados utilizando alinhamento de ciliados e modelo nulo igual à distribuição de fundo de P. falciparum; C: TERCs de vertebrados utilizando alinhamento de vertebrados e modelo nulo uniforme; D: TERCs de vertebrados utilizando alinhamento de vertebrados e modelo nulo igual à distribuição de fundo de P. falciparum. . . . . . . . . . . . . .

5.7 Escores médios de 50 shufflings de cada TERC utilizando como modelo nulo a composição de bases das seqüências de treinamento. A: TERCs de ciliados utilizando alinhamento de ciliados; B: TERCs de vertebrados utilizando alinhamento de vertebrados. . . . . . . . . . . . . . . . . . . . 88

5.8 Escores médios de 50 shufflings de cada TERC utilizando como modelo nulo a composição de bases da seqüência query. A: TERCs de ciliados utilizando alinhamento de ciliados; B: TERCs de vertebrados utilizando alinhamento de vertebrados. . . . . . . . . . . . . . . . . . . . . . . . . . . . 89

5.9 Etapas de processamento do sistema TERP. . . . . . . . . . . . . . . . . . . . . . . . . 91

5.10 Arquitetura modificada do modelo de covariância relativo ao trecho do template telomérico e sua extensão. Flechas de transição com linhas engrossadas correspondem a transições que tiveram suas probabilidades aumentadas. Transições com probabilidade zero tiveram suas flechas removidas em relação à arquitetura original. Ao lado do triângulo de emissão estão representadas as únicas emissões possíveis. Ao lado direito um número rotula cada conjunto de estados a ser referenciado no texto. . 93

5.11 Intersecção de candidatos preditos pelo sistema TERT em P. falciparum, P. yoelii e P. vivax. . . . . 100

6.1 Representação em forma de grafo da estrutura secundária de TERC de ciliados para a região delimitada pela hélice 1: hélice 1 (H1), hélice 2 (H2), hélice $3(\mathrm{H} 3)$ e pseudo-nó $(\mathrm{P})$. A parte superior e inferior do grafo correspondem à mesma seqüência na mesma orientação $\left(5^{\prime} \rightarrow 3^{\prime}\right)$. Arestas que conectam nós apenas da parte superior ou inferior são usadas para representar a ordem entre os nós na seqüência, enquanto arestas que cruzam as duas partes são usadas para representar pareamentos. A linha pontilhada não faz parte do grafo, mas apenas faz alusão à seqüência em questão. . . . . . 111 



\section{Lista de Tabelas}

1.1 Exemplos de RNAs não codificantes. . . . . . . . . . . . . . . . . 2

4.1 Resultados de alinhamentos locais entre 12 bases upstream do template telomérico de ciliados e vertebrados contra o consenso [C]TGTCA. . . . . . . . . . . . . . . . . . . . . . . . . . . . 55

4.2 Resultados dos alinhamentos da região 5' não transcrita com o padrão (G|A)ACCCATAA(T|A)5. A distância da posição -63 indica quantas bases há de diferença entre a posição do alinhamento e a posição esperada do padrão (G|A)ACCCATAA(T|A)5 (-63) . . . . . . . . . . . . . . . . . . . . 56

4.3 Resultados do alinhamento da região 5' não transcrita com o padrão (T|A)TTA(T|A). A distância da posição -28 indica quantas bases há de diferença entre a posição do alinhamento e a posição esperada do padrão (-28). A coluna de "Distância entre padrões" indica quantas bases há de diferença na distância esperada (35) entre os padrões (G|A)ACCCATAA(T|A)5 e (T|A)TTA(T|A). $\quad$. . . . . . 57

5.1 Tabela de substituição de cada estado representado na árvore guia (coluna 1) por um conjunto de estados (coluna 2) no modelo de covariância final. Estados não mencionados na tabela não são substituídos. . . . . . . . . . . . . . . . . . . . . . . . . . . . . 83

5.2 Resultados de validação leave-one-out em vertebrados. A tabela está ordenada pela coluna 3.98

5.3 Resultados da aplicação do TERP na busca de candidatos a TERP em vertebrados sem TERC conhecida. . . . . . . . . . . . . . . . . . . . . . . . . . . . . . . . . 99

C.1 Programas disponíveis e servidores web para predição de estrutura secundária. . . . . 120

C.2 Programas disponíveis e servidores web para comparação estrutural e identificação de ncRNAs. . . . . . . . . . . . . . . . . . . . . . . . . . . . . . . . . . . . . . . . . . . 



\section{Introdução}

\subsection{RNAs não codificantes}

Até pouco tempo atrás, os RNAs eram considerados meros intermediários entre o genoma e as proteínas, como rege o dogma central da biologia. Recentes descobertas envolvendo uma variedade de novos genes de RNAs não codificantes (ncRNAs), seus papéis biológicos e mecanismos de ação [160] têm mostrado que a diversidade e a importância dos ncRNAs foram subestimadas [120]. Atualmente, sabe-se que RNAs que não codificam proteínas desempenham importantes funções.

As famílias de ncRNAs conhecidas até os anos 80 eram as de tRNAs (RNAs responsáveis pelo transporte do aminoácido correspondente a cada códon) [251] e rRNAs (RNAs ribossomais responsáveis pela catálise de síntese proteica) [48]. O número de famílias atualmente conhecidas já ultrapassa 500 (versão 7 do banco de dados Rfam [101]), e o número total de ncRNAs conhecidos, incluindo exemplos isolados não incluídos em uma família específica, ultrapassa 800 somente em mamíferos [177], com tamanhos variando de 21 [108] a 108.000 bases [249]. A enumeração de todos esses ncRNAs seria muito extensa. A tabela 1.1 traz uma lista de alguns destes para exemplificar a diversidade de funções que eles desempenham.

Em particular, algumas categorias de RNAs têm estado em evidência, estando presentes em diversas espécies de organismos. Podemos citar entre elas, os snRNAs (envolvidos no processo de splicing) [273], snoRNAs (responsáveis por realizar modificações em outros RNAs) [197], RNases P e MRP (responsáveis pelo processamento de tRNAs e rRNAs, respectivamente) [204], 7SL e 4.5S (envolvidos no reconhecimento de sinal peptídeo para transporte de proteínas) [189, 283], miRNAs (regulação gênica pós-transcricional) [108], TERC (template da síntese telomérica) [98] e tmRNA (liberação de mRNAs defeituosos) [104].

Os RNAs não codificantes estão envolvidos em várias atividades celulares, tais como silenciamento de genes [106], replicação [98], regulação da expressão gênica [147], transcrição [293], esta-

bilidade cromossômica [16], estabilidade [59], translocação [136] e localização [223] de proteínas 
e modificação [163], processamento [24] e estabilidade [254] de RNAs. Longos ncRNAs antisenso têm sido encontrados em muito genomas, e parecem estar envolvidos em regulação de expressão gênica $[120,184,213,214]$.

Tabela 1.1: Exemplos de RNAs não codificantes.

\begin{tabular}{lll}
\hline RNA & Função & Referência \\
\hline & & \\
6 S & Inibição de uso de promotores específicos & {$[282]$} \\
7 H4 & Regulação gênica em sinapses & {$[275]$} \\
7 SK & Regulação do fator de elongação P-TEFb & {$[18]$} \\
7 SL, 4.5S & Transporte de proteínas (reconhecimento de sinal) & {$[189,283]$} \\
AIR & Imprinting & {$[249]$} \\
B2 & Inibição de transcrição durante heat shock response & {$[282]$} \\
BC1 & Ativação de proteínas repressoras & {$[297]$} \\
BC200 & Resposta a estresse & {$[172]$} \\
BIC & Controle de crescimento / ativação de células T & {$[159,259]$} \\
CSRB/CSRC e RSMY/RSMZ & Inibição de proteínas repressoras & {$[255]$} \\
HDV ribozima & Catálise de auto-clivagem & {$[83]$} \\
KHPS1a & Demetilação de DNA & {$[121]$} \\
miRNA & Regulação gênica pós-transcricional & {$[108]$} \\
NRON & Repressão do fator de transcrição NFAT & {$[177]$} \\
NRSE & Modulação de diferenciação & {$[145]$} \\
& de células tronco neuronais & \\
OxyS & Repressão de tradução & {$[283]$} \\
& impedindo o binding do ribossomo & \\
rRNA & Função estrutural e catalítica & {$[48]$} \\
RNase P & de síntese proteica nos ribossomos & \\
RNase MRP & Processamento de tRNAs & {$[204]$} \\
SL & Processamento de rRNAs & {$[204]$} \\
SRA & Maturação de mRNAs & {$[58]$} \\
snoRNA & Co-ativação seletiva de receptores de esteróide & {$[150]$} \\
TERC & Modificações de outros RNAs & {$[163]$} \\
tmRNA & Template da síntese telomérica & {$[98]$} \\
tRNA & Liberação de mRNAs defeituosos & {$[104]$} \\
U1 snRNA & Tradução códon-aminoácido & {$[251]$} \\
U1, U2, U4, U5 e U6 snRNAs & Splicing & {$[146]$} \\
vault RNAs & Transporte / associação com resistência a drogas & {$[274]$} \\
XIST, TSIX e roX & Inativação do cromossomo X & {$[42,181]$} \\
\hline & & \\
& &
\end{tabular}


Alguns ncRNAs são expressos específica ou abundantemente em determinados estágios, como o ODD1 [123] e o lin-4 [123, 154], ou em tecidos específicos, como o 7H4 [275] e certos miRNAs [148], evidenciando seu papel regulatório. Outros estão relacionados com doenças.

Os RNAs BIC, PCGEM1, DD3, MALAT-1, BC1, BC200, TERC, H19, HIS-1, alguns RNAs antisenso intrônicos e alguns miRNAs estão associados a diversos tipos de câncer [52, 213, 214].

Outros ainda estão relacionados com doenças neurológicas:

- síndromes de Prader-Willi e Angelman: RNAs IPW, ZNF127, UBE3A, LANCAT, HBII-52 e alguns snoRNAs $[52,86]$;

- esquizofrenia: RNAs PSZA11q14 e DISC2 [185, 207];

- síndrome de Beckwith-Wiedemann: RNAs H19 e LIT1 [52];

- síndrome do X frágil: RNA BC1 [255];

- Alzheimer: BC200 [166]

- doenças neuro-degenerativas como spinocerebellar ataxia: RNA SCA8 [177].

Recentemente, foi identificado o RNA MIAT, relacionado com o infarto do miocárdio [124]. A disceratosis congênita é relacionada com mutações no TERC [6]. A má formação ou não existência de foto-receptores está relacionado com o RNA TUG1, expresso especificamente no cérebro e na retina [177].

Outros elementos não codificantes com papel regulatório ainda podem ser adicionados a essa lista. Exemplos desses elementos presentes em mRNAs ou pré-mRNAs são algumas UTRs ( $U n$ translated Region) [278], íntrons catalíticos [232, 288] e riboswitches [95].

Estima-se que muito mais ncRNAs ainda não foram descobertos [74, 120]. Especula-se que estas moléculas podem explicar melhor as diferenças na complexidade dos vários organismos do que as proteínas [161]. Surge um novo cenário revelando que o dogma central (figura 1.1A) pode ser muito mais complexo, no qual ncRNAs desempenham relevantes papéis (figura 1.1B).

Estas novas descobertas têm motivado a pesquisa de ncRNAs em muitos aspectos. Por exemplo, uma vez que a estrutura secundária de um RNA e sua função são estreitamente relacionadas, é desejável saber a estrutura comum entre RNAs homólogos a fim de descobrir assinaturas funcionais. É também desejável varrer um genoma em busca de ncRNAs. Porém, o número de possíveis estruturas secundárias de um RNA cresce exponencialmente com o seu tamanho. Estratégias usadas para a identificação de genes de proteínas freqüentemente falham quando usadas na identificação de ncRNAs. Apesar do grande número de ferramentas que vem sendo desenvolvidas para a pesquisa 

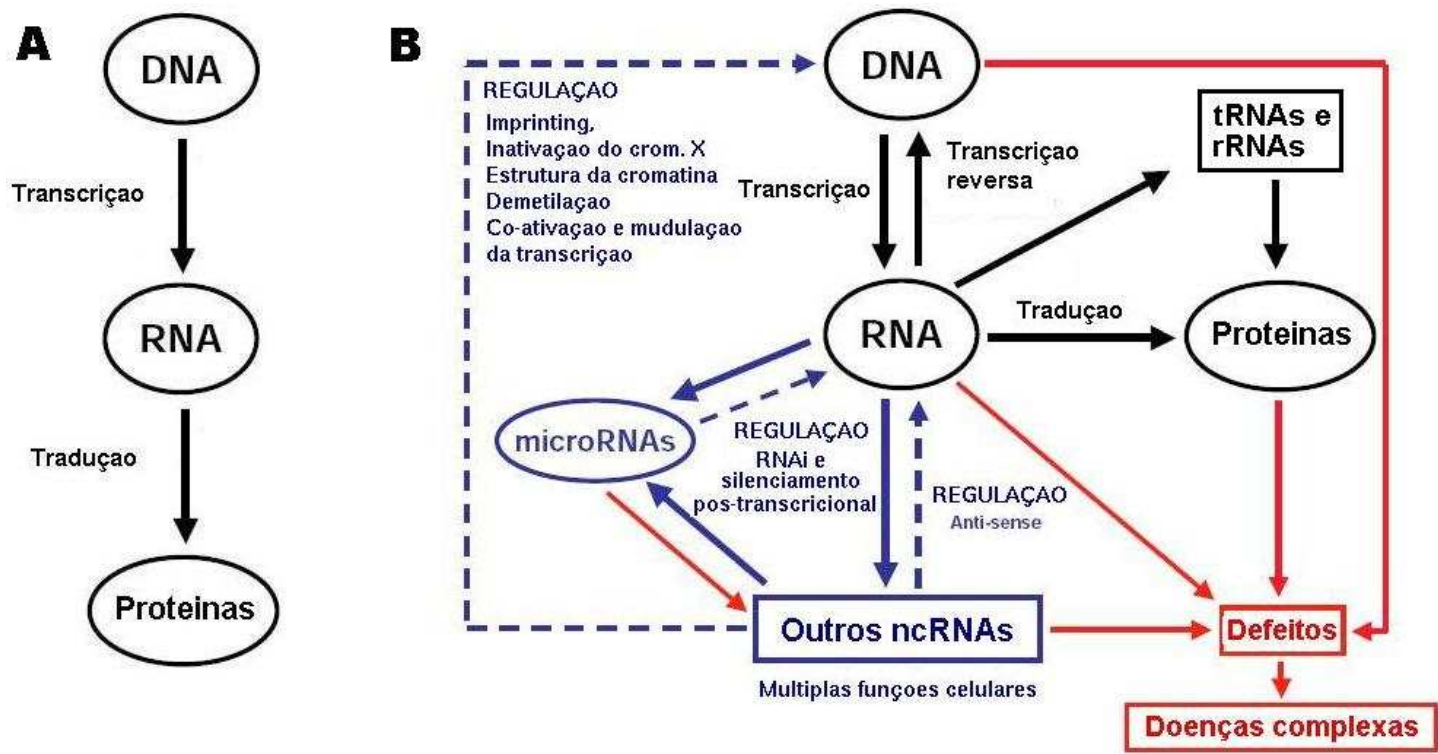

Figura 1.1: A: Fluxo molecular considerado como o dogma central da biologia. B: Representação esquemática de um novo fluxo molecular emergindo de recentes descobertas (adaptado de [52]).

computacional de RNAs, identificação in silico de ncRNAs é ainda um problema em aberto em bioinformática [75, 164, 187].

\section{Estrutura secundária}

A maioria dos RNAs apresentam-se como moléculas de fita-única, podendo se dobrar formando pareamentos de bases através de pontes de hidrogênio. Estes pareamentos freqüentemente ocorrem entre as bases G-C, A-U e, ocasionalmente, G-U.

Estes pareamentos formam componentes estruturais (figura 1.2) conhecidos como:

- hélice ou stem: um empilhamento contínuo de pares de bases;

- loop: uma região de bases não pareadas;

- hairpin loop: um loop encerrado por uma hélice;

- multi-loop: uma região de loop da qual partem três ou mais hélices;

- loop interno: um loop dentro de uma hélice; um loop interno é assimétrico se o número de nucleotídeos em cada lado da hélice é diferente, e simétrico caso contrário;

- bojo: um loop dentro de apenas um lado de uma hélice. 


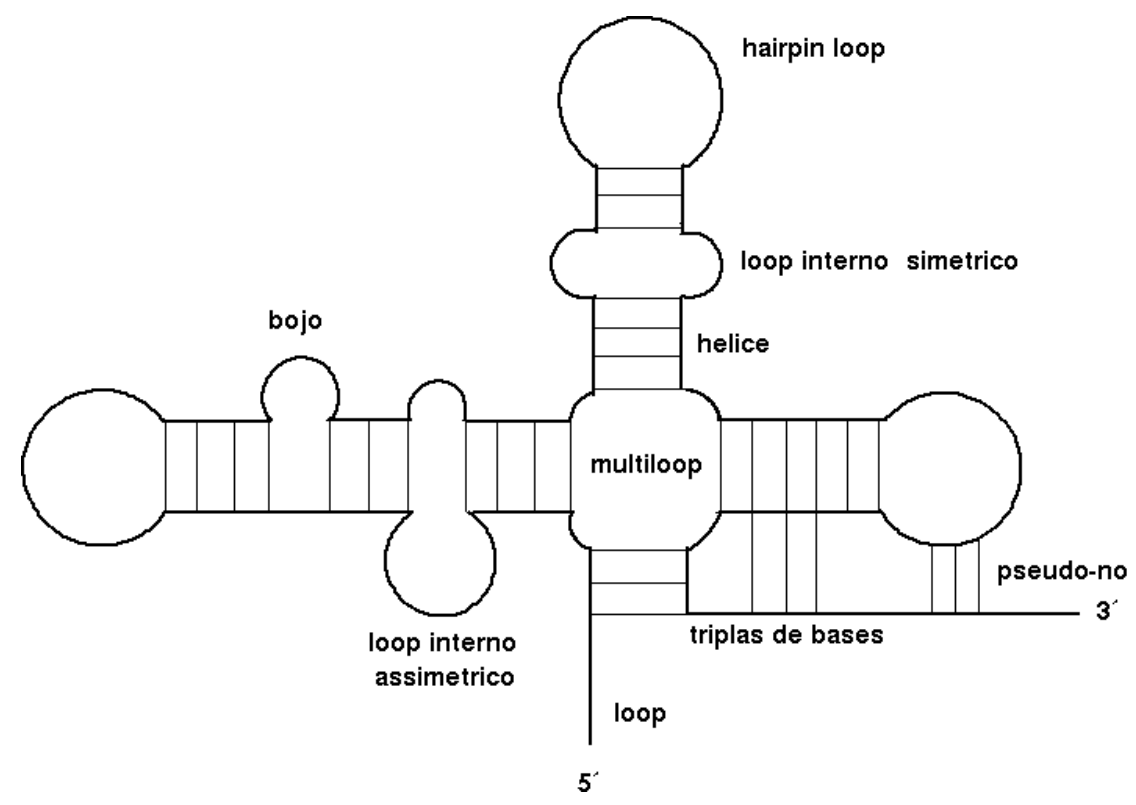

Figura 1.2: Componentes estruturais de uma estrutura secundária de RNA.

Além dos componentes de estrutura secundária definidos acima, pares de bases podem participar de dois outros componentes: pseudo-nós (hélices que se cruzam) e triplas de bases (interações envolvendo três bases). Estas outras interações de bases são consideradas parte da estrutura terciária.

\section{$1.2 \quad$ Plasmodium falciparum e RNAs não codificantes}

Plasmodium falciparum é a espécie de parasita humano que causa o tipo mais letal de malária [93]. A malária é uma doença cujo número estimado de casos é de 300 a 600 milhões por ano no mundo, causando 2.7 milhões de mortes por ano, das quais $90 \%$ são de crianças de 0 a 5 anos $[105,171]$.

Poucos ncRNAs foram identificados em $P$. falciparum, o que o torna um desafio para as ferramentas de predição desses genes. Foram identificados apenas RNAs transportadores (tRNAs) [93], RNAs ribossomais (rRNAs) [93], RNase P e MRP [204], componentes RNA de partículas de reconhecimento de sinal (SRP RNAs - signal recognition particle RNAs) [224] e pequenos RNAs nucleares (snRNAs - small nuclear RNAs) [9], além de RNAs antisenso sem função conhecida [184].

Este organismo revela características incomuns com relação a muitas dessas famílias. O total de 43 tRNAs é muito inferior ao apresentado pela maioria dos organismos, como por exemplo Schizosaccharomyces pombe, que possui 174 tRNAs [93]. O total de rRNAs também é baixo: 3 cópias do gene 5S rRNA (contra 30 de $S$. pombe) e 7 cópias das unidades de transcrição 5.8S- 
18S-28S rRNAs (contra 200-400 em S. pombe), sendo que estas estão distribuídas em diferentes cromossomos ao invés de se apresentarem em posições adjacentes, como é comum [93]. A RNase P e MRP chegam a ser mais de 4 vezes maiores do que em outras espécies [204]. O SRP RNA também é maior, com alteração da estrutura secundária em pelo menos um dos domínios [224]. Tais evidências indicam que outros ncRNAs em P. falciparum podem também possuir características incomuns e que, portanto, a tarefa de predição de ncRNAs neste organismo deve ser ainda mais desafiadora.

$P$. falciparum é um organismo incomum não apenas no que se refere a ncRNAs. Aproximadamente $60 \%$ das proteínas preditas em $P$. falciparum não apresentam similaridade com proteínas de outros organismos [93]. Além disso, muitas proteínas, como polimerases e transcriptases reversas, possuem um tamanho consideravelmente maior (até 2.85 vezes) do que em outras espécies [85].

O genoma de $P$. falciparum está completamente seqüenciado [14, 93]. Trata-se de $23 \mathrm{Mb}$ de um genoma altamente rico em AT (81.6\%). Tal desproporção na composição de bases causa distorções nos resultados de muitas ferramentas de bioinformática que se baseiam em estatísticas de nucleotídeos e que supõem uma distribuição uniforme sobre os nucleotídeos $(P(A)=P(C)=P(G)=$ $P(T)=0.25)$.

Todas essas características fazem de P. falciparum um bom objeto de estudo para a pesquisa das principais fraquezas das atuais abordagens de identificação de ncRNAs. Além dos desafios de bioinformática, há também uma forte motivação biológica. Muitos RNAs não codificantes exercem um papel de regulação gênica. A descoberta de novos RNAs não codificantes neste parasita pode auxiliar no melhor entendimento de seu funcionamento celular, fornecendo novos conhecimentos para o desenvolvimento de vacinas e drogas.

Uma busca por ncRNAs pode ter como objetivo a identificação de ncRNAs em geral ou a predição de ncRNAs de uma família específica. Neste trabalho, o problema de busca por ncRNAs em geral em P. falciparum foi tratado utilizando uma abordagem comparativa com Plasmodium yoelii, a fim de identificar ncRNAs conservados nestas duas espécies. P. yoelii é uma espécie filogeneticamente próxima de $P$. falciparum, com genoma seqüenciado e com características comuns com $P$. falciparum, como o alto conteúdo AT (77.4\% em P. yoelii) [29]. O problema de busca por uma família específica foi tratado utilizando uma abordagem $a b$ initio, utilizando o componente RNA da telomerase como objeto de estudo.

\subsection{O componente RNA telomerase}

O TERC (TElomerase RNA Component) é um importante ncRNA que participa do complexo telomerase. Este complexo, em muitos organismos, é responsável pela manutenção dos telômeros. Este RNA é também um desafio pelo fato de ser de difícil identificação, e portanto um bom objeto de 
estudo. Esta seção descreve brevemente a importância dos telômeros, o mecanismo de manutenção telomérica pelo complexo telomerase, aspectos do componente RNA relevantes à sua identificação e sua relação com o organismo modelo deste trabalho, Plasmodium falciparum.

\subsubsection{Os telômeros e sua manutenção}

A maioria dos cromossomos lineares possui nas suas extremidades uma estrutura nucleoproteica diferente da encontrada em sua região interna [216]). H. Muller, durante seus experimentos com Drosophila no final da década de 1920, foi o primeiro a chamar essa estrutura de telômero (em grego, "parte final") [91]. A seqüência de DNA do telômero é formada por repetições consecutivas de um padrão espécie-específico chamado repetição telomérica [109]. Em seres humanos, por exemplo, essa repetição é GGGTTA.

Os telômeros estão envolvidos na estabilidade das extremidades dos cromossomos, impedindo fusões entre eles (revisado em [91]). Além de impedir fusões indesejáveis, os telômeros protegem os cromossomos de outros problemas como o reconhecimento de suas extremidades pelo mecanismo de reparo como uma quebra cromossomal [49, 167, 287], ação descontrolada de nucleases [216] e perda de informação genética durante os ciclos de replicação [30,31]. Os telômeros também estão envolvidos na arquitetura nuclear, possuindo importante papel na divisão celular de muitos organismos $[12,239]$.

\section{O problema da replicação das pontas}

As DNA polimerases possuem a capacidade de sintetizar polímeros de DNA apenas na direção $5 ' \rightarrow 3$ '. Durante o processo de replicação de cromossomos lineares, como as duas fitas de DNA são anti-paralelas, uma das fitas é sintetizada de forma contínua conforme a DNA polimerase avança pelo DNA. A outra, no entanto, como precisa ser sintetizada na direção contrária ao avanço da enzima, é sintetizada em fragmentos, conhecidos como fragmentos Okazaki. Em cada trecho, seja na fita sintetizada continuamente — leading strand — ou na fita sintetizada em fragmentos lagging strand - a replicação inicia-se a partir de um primer de RNA, sintetizado por uma RNA polimerase. Essas bases de RNA são trocadas por DNA durante a extensão do final 3' do fragmento Okazaki adjacente (figura 1.3).

No entanto, ocorre um problema na replicação das pontas cromossomais. Os primers dos fragmentos Okazaki são formados a cada 200 bases aproximadamente. Se o último fragmento da fita lagging (a fita sintetizada em fragmentos) se iniciar a menos de 200 bases do extremo 3' dessa fita, poderá não ocorrer a formação de um primer no trecho restante e, conseqüentemente, este trecho não será replicado. Isso torna a fita filha mais curta que a fita parental. Mesmo que este último 


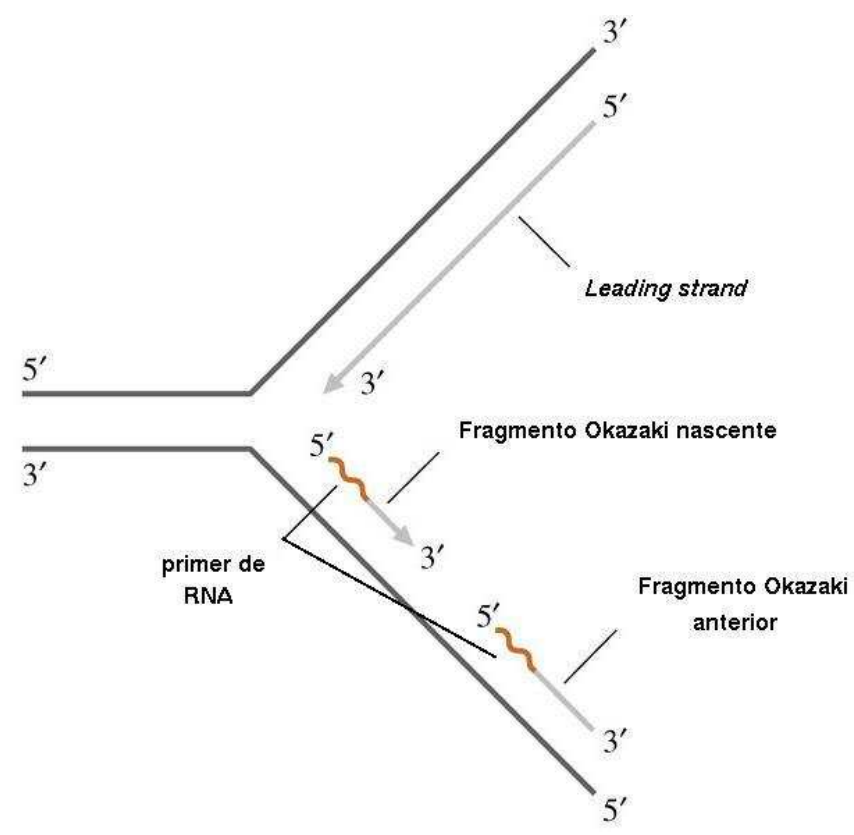

Figura 1.3: Replicação de DNA e fragmentos Okazaki

primer seja formado exatamente a partir da última base, não haveria a substituição do primer de RNA por DNA, pois não haveria fragmento Okazaki adjacente do lado 3' para ser estendido. Não se sabe se esta molécula filha conseguiria manter esse primer de RNA durante o ciclo celular, nem se este trecho poderia ser copiado em uma etapa subseqüente de replicação [27].

A presença dos telômeros permite que essa perda de DNA aconteça sem que haja perda de informação genética. No entanto, como os telômeros possuem um tamanho finito, estes precisam ser restaurados para manter essa proteção.

A restauração telomérica em muitos organismos é efetuada pelo complexo telomerase, como descrito na próxima subseção. No entanto, alguns organismos podem utilizar outros mecanismos. Drosophila, o organismo no qual os telômeros foram originalmente estudados, ironicamente é uma das exceções. Neste organismo retrotransposons são encarregados pela manutenção dos telômeros através de sua transposição para os extremos dos cromossomos [182]. Estudos também revelaram que em alguns organismos cuja manutenção telomérica é feita pelo complexo telomerase, células deficientes em telomerase podem sobreviver à morte celular através de mecanismos alternativos. Células de Saccharomyces cerevisiae, por exemplo, podem utilizar recombinações na região telomérica e subtelomérica para amplificar seus telômeros. Também são observados sobreviventes de levedura que contornaram a necessidade de telômeros circularizando seus cromossomos [167].

A síntese telomérica não deve ocorrer necessariamente a cada ciclo de replicação. Na verdade, é 
preciso que ocorra um equilíbrio entre a perda e a síntese dos telômeros, a fim de que genes ou regiões regulatórias não sejam perdidos nem que sejam criados cromossomos com telômeros gigantes.

\subsubsection{Atividade telomerase}

\section{Mecanismo de síntese}

O complexo telomerase é formado por várias proteínas e um componente de RNA, o TERC [17]. Esse RNA possui o template da repetição telomérica. Esse template é utilizado por uma transcriptase reversa (TERT - Telomerase Reverse Transcriptase), uma das proteínas do complexo, para sintetizar DNA nos extremos 3' dos cromossomos. O processo de síntese é composto por três fases: anexação do primer, polimerização e translocação (figura 1.4).

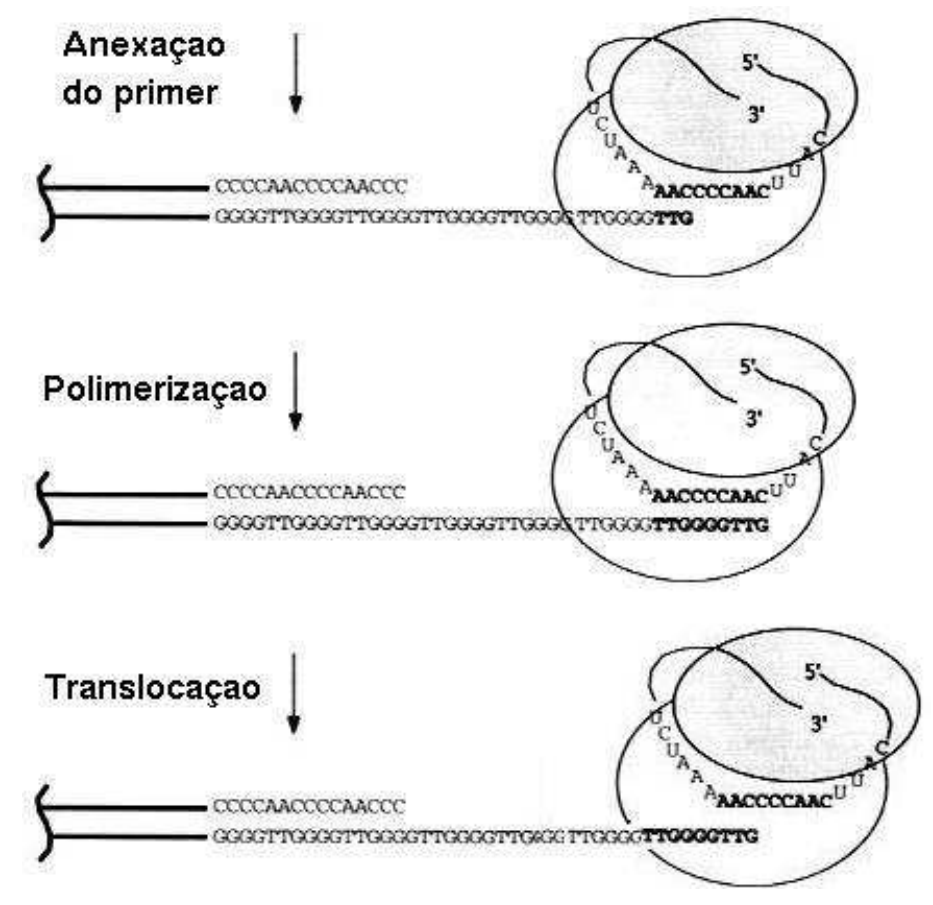

Figura 1.4: Processo de síntese telomérica (adaptado de [98])

Na primeira etapa, ocorre o pareamento (anelamento) entre o final 3' do cromossomo, que funciona como primer para síntese telomérica, e a porção final 3' do template. Para que esse pareamento ocorra e o template ainda esteja livre para servir de molde para uma repetição completa, a porção do RNA a ser pareada com o DNA é uma extensão do template. Esta extensão deve coincidir com as primeiras bases do template (na figura 1.4, o template é 5'CAACCC3', e o template com a extensão de 3 nucleotídeos é 5'CAACCCCAA3'). Durante a segunda etapa, o template de RNA 
é reversamente transcrito para os telômeros. Conforme as bases do template vão sendo copiadas, os primeiros pareamentos RNA-DNA são desfeitos. A terceira etapa envolve a translocação do complexo de forma a ocorrer um novo pareamento entre o primer e o template, e assim iniciar a síntese de uma nova cópia da repetição telomérica [98].

Finalmente, após alguns ciclos de síntese, o complexo se disassocia do telômero. O DNA recém sintetizado serve então de molde para a síntese telomérica da fita oposta. Essa síntese é agora feita por uma DNA polimerase.

\section{Telomerase, senescência, câncer e outras doenças}

Um cromossomo eucariótico perde de 50 a 200 bp a cada replicação. Em células com ausência de atividade telomerase, os telômeros vão sendo encurtados até atingir um tamanho crítico. Quando isso ocorre, a célula perde sua capacidade de replicação, iniciando um processo de senescência que culmina na morte celular. Em células somáticas normais, este processo de senescência relacionase com o processo de envelhecimento, uma vez que a telomerase não é normalmente ativa nestas células. Além disso, o encurtamento acelerado de telômeros pode levar a doenças como a síndrome de Werner [6].

Apesar da telomerase não ser ativa em células somáticas normais, estudos têm mostrado sua atividade em células tumorais de pelo menos 12 tipos de tumor. Imortalizadas, essas células possuem grande capacidade replicativa, permitindo sua proliferação indefinida [137].

A telomerase é normalmente ativa em células tronco e germinativas. O funcionamento deficiente da telomerase em células tronco pode, por exemplo, afetar a manutenção de tecidos e causar certos tipos de anemia [6]. A anemia é um dos sintomas da disceratosis congênita, uma doença associada a mutações na TERT ou no TERC [6].

\subsubsection{O componente RNA}

Os TERCs possuem uma alta taxa de mutação [38]. Conseqüentemente, TERCs de diferentes organismos podem ser muito divergentes, e o são não só em seqüência, mas também em tamanho e estrutura secundária. Essa divergência dificulta a sua caracterização e identificação tanto por abordagens biológicas quanto computacionais, deixando esse ncRNA de fora de muitas predições [28, 56, 186, 206, 257]. Os TERCs identificados até o momento podem ser divididos em três grupos: de ciliados, de leveduras e de vertebrados. Todos eles são de cópia única no genoma. Além destes, um vírus que infecta galinha possui não uma, mas duas cópias idênticas do TERC. Estes TERCs possuem $88 \%$ de identidade com o TERC de seu hospedeiro, e são expressos apenas nas cepas 
oncogênicas $^{1}[89]$.

TERCs de cada um desses grupos possui um tamanho típico. TERCs de ciliados possuem tamanho de $\approx 180 \mathrm{nt}$, de vertebrados $\approx 400$ nt e de leveduras $\approx 1300$ nt [35]. Assim como outros RNAs não codificantes, os TERCs possuem maior conservação em sua estrutura secundária do que em sua seqüência (estrutura primária). No entanto, a diferença de tamanho entre seqüências de ciliados, vertebrados e leveduras causa também uma diferença na estrutura secundária consenso desses três grupos. Apesar disso, TERCs de ciliados e vertebrados compartilham um certo padrão de estrutura secundária, e os três grupos possuem domínios importantes em comum. Semelhanças e diferenças entre essas estruturas podem ser vistas na figura 1.5.

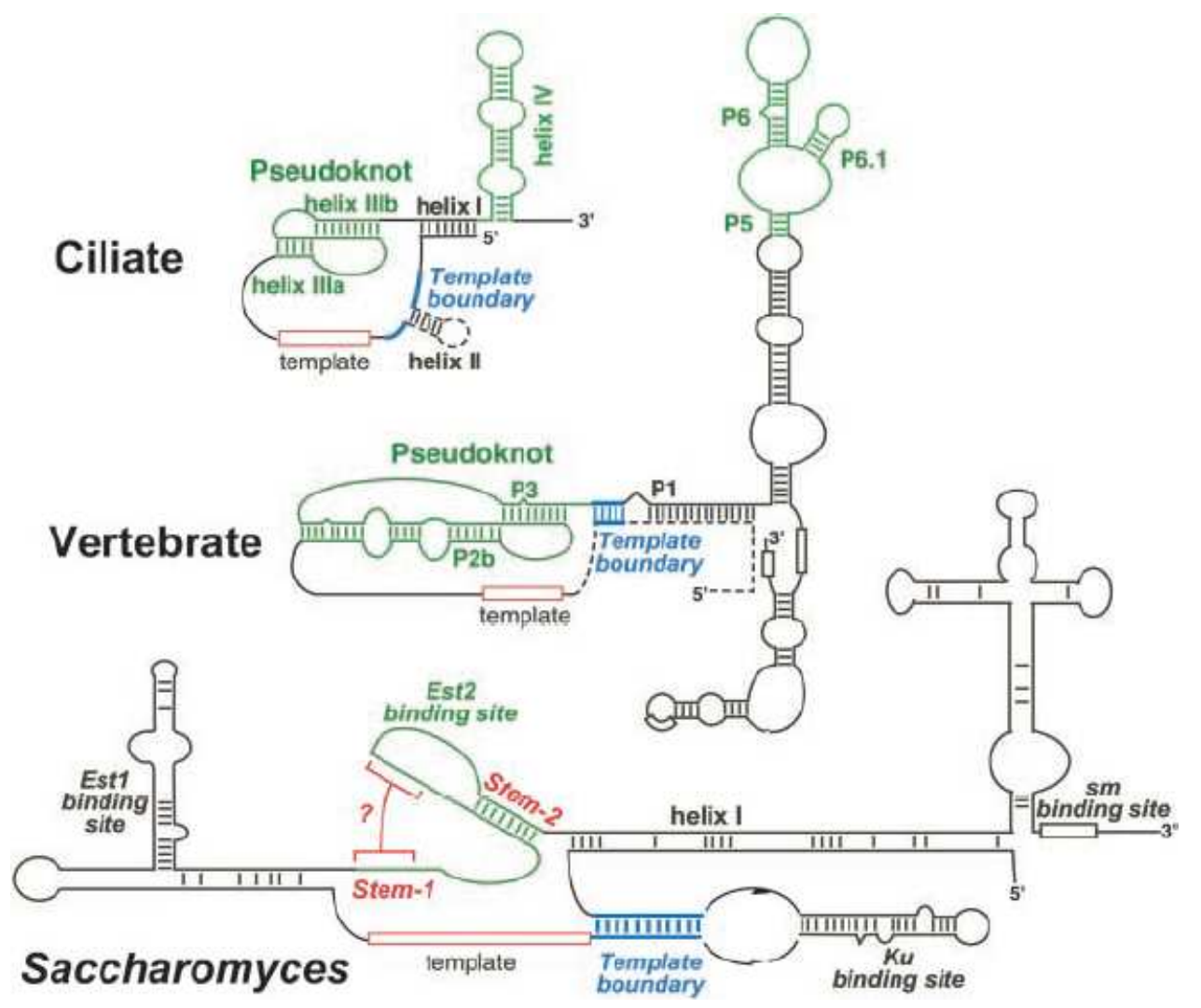

Figura 1.5: Estruturas consenso de TERCs de ciliados, vertebrados e leveduras. Figura de [38].

Essa diferença de tamanho pode também refletir diferenças na RNA polimerase que transcreve esses RNAs. Acredita-se que TERCs de vertebrados e leveduras sejam transcritos pela RNA polime-

\footnotetext{
${ }^{1}$ Devido à alta similaridade com o TERC de seu hospedeiro, este TERC pode ser conseqüência de transferência horizontal. Devido a esse fato e à alta similaridade com o TERC hospedeiro, este TERC é considerado neste trabalho juntamente com o grupo de TERCs vertebrados.
} 
rase II [33, 35]. Ainda não se sabe qual RNA polimerase transcreve os TERCs de ciliados. Por não possuir 5' cap nem cauda poli-A, acredita-se que não seja a RNA polimerase II. Devido à presença de uma pequena cauda poli-U, cogita-se a possibilidade de ser a RNA polimerase III a responsável pela transcrição desses TERCs [222].

\subsubsection{Telomerase em Plasmodium falciparum}

Plasmodium falciparum é um parasita unicelular. Cada parasita que infecta o hospedeiro humano pode originar mais de 32.000 (mais de $2^{15}$ ) novos parasitas durante seu ciclo inicial nas células hepáticas. Isso exige que o genoma original passe por pelo menos 15 etapas de replicação. Posteriormente, o parasita inicia seu ciclo eritrocítico, onde origina de 8 a 32 novos parasitas (3 a 5 etapas de replicação) a cada 48 horas [206]. Soma-se a essa demanda de replicação a observação de quebras cromossomais seguidas de formação de novos telômeros [21]. Estes fatos indicam que a atividade telomerase deve ser fundamental para manter a integridade cromossomal deste organismo [238] e que, portanto, a inibição dessa atividade deve levar o parasita à senescência. Essa hipótese faz do complexo telomerase um potencial alvo de drogas.

O TERC ainda não foi identificado em Plasmodium falciparum [21, 206]. Porém, a atividade telomérica em P. falciparum já foi descrita $[21,208]$ e seu componente proteico de transcriptase reversa, TERT, já foi caracterizado [85]. O tratamento tanto com protease quanto com RNase inibe a atividade telomérica neste organismo, indicando que os dois componentes, o proteico e o ribonucleico (RNA), são essenciais para o funcionamento da enzima. Portanto, esse RNA deve estar presente e ser funcional no genoma de $P$. falciparum.

O componente proteico TERT de $P$. falciparum apresenta uma seqüência 2.5 vezes maior que as demais TERTs conhecidas ${ }^{2}$ [85]. Não sabemos se essa diferença no tamanho da TERT exige uma alteração do tamanho do RNA.

P. falciparum não possui uma repetição única nos telômeros. No entanto, as repetições GGGTTTA e GGGTTCA somam 80\% dos telômeros. Algumas hipóteses para esse telômero degenerado são a existência de mais de um TERC ou a falta de precisão da enzima [21]. A última hipótese é mais coerente com dois fatos: primeiro, sabe-se até o momento que TERCs de organismos eucariotos são genes de cópia única; segundo, espécies de Paramecium, que possuem uma única cópia de TERC,

\footnotetext{
${ }^{2}$ Uma hipótese para o aumento de tamanho não só da TERT como também de outras proteínas em $P$. falciparum é que, devido ao alto conteúdo AT de seu genoma, regiões com pouca complexidade causam escorregamento da polimerase durante as replicações genômicas, causando amplificação dessas regiões. Se estas regiões não estão sob uma pressão funcional, essas amplificações são acumuladas. Tal hipótese se encaixa com as características da $P f$ TERT, pois seus domínios funcionais são conservados em tamanho e seqüência enquanto as regiões aparentemente não funcionais (não conservadas entre várias espécies) são ricas em AT e de baixa complexidade [85].
} 
também possuem repetição telomérica degenerada devido a falhas de incorporação de nucleotídeos pela TERT [180]. No entanto, não se pode excluir a possibilidade de existência de duas ou mais cópias do gene de TERC em um genoma.

\subsubsection{TERC em $P$. falciparum como objeto de estudo}

O TERC é um ncRNA importante que ainda não foi identificado em $P$. falciparum, mas evidências biológicas indicam que ele está presente e é funcional. Além da busca de ncRNAs em P. falciparum ser um desafio, a identificação de TERCs também o é, devido à alta taxa de mutação deste RNA. Em ciliados e vertebrados, o TERC possui um tamanho variando de aproximadamente 150 a 560 bases. Portanto, não são pequenos e simples demais mas ainda possuem um tamanho tratável por ferramentas computacionais. Da mesma forma, a estrutura secundária apresentada por esses RNAs não é tão complexa como, por exemplo, as de SSU (Small Sub-Unit) e LSU (Large Sub-Unit) rRNAs, mas possui diversidade de componentes estruturais. Além disso, a identificação do TERC em $P$. falciparum possui uma apelo clínico, uma vez que esse RNA pode ser usado como alvo de drogas.

\subsection{Objetivo}

O objetivo deste trabalho é realizar um estudo sobre técnicas computacionais para a predição de RNAs não codificantes e, utilizando como objeto de estudo Plasmodium falciparum, propor uma metodologia de predição que seja aplicável também a genomas com viés composicional. A ênfase deste estudo foi predição de ncRNAs família-específicos, tendo TERCs como objeto de estudo utilizando uma abordagem $a b$ initio. Além disso, foi realizado um trabalho preliminar sobre predição de ncRNAs em geral utilizando uma abordagem comparativa.

Quando se busca um RNA de uma determinada família, o conhecimento a cerca desta família de interesse pode ajudar significativamente o processo de identificação. Desta forma, uma parte de nosso trabalho foi dedicada ao estudo de TERCs e a análises preliminares de candidatos a TERC em Plasmodium falciparum utilizando abordagens heurísticas.

\subsection{Sobre a organização do trabalho}

O capítulo 2 apresenta uma revisão bibliográfica de métodos computacionais para a pesquisa de RNAs não codificantes. O capítulo 3 descreve a utilização de uma abordagem comparativa para predição de ncRNAs em geral em Plasmodium falciparum. O capítulo 4 descreve as abordagens

heurísticas, termodinâmicas e gramaticais que utilizamos inicialmente na tentativa de identificação 
do TERC. O capítulo 5 descreve o sistema TERP desenvolvido para predição de TERCs, o tratamento para genomas com viés composicional e sua aplicação em alguns organismos sem TERC conhecido, incluindo Plasmodium falciparum. O capítulo 6 apresenta conclusões acerca do trabalho desenvolvido e trabalhos futuros.

O apêndice A traz um glossário de alguns termos usados no texto, estes escritos em negrito. O apêndice B traz abreviaturas usadas nesta tese. O apêndice C traz uma lista de todos os programas disponíveis e servidores web citados no capítulo 2 .

Alguns termos em inglês não foram traduzidos devido ao seu uso comum no vocabulário de bioinformática. Esses termos estão escritos em itálico. 
Capítulo 2

\section{Métodos computacionais na pesquisa de ncRNAs}

A descoberta de novas famílias de ncRNAs e sua importância biológica tem motivado a pesquisa de ncRNAs em muitos aspectos. Por exemplo, uma vez que a estrutura e a função de um RNA são estreitamente relacionadas [241, 265], é desejável conhecer a estrutura comum de RNAs que desempenhem a mesma tarefa em diferentes organismos (RNAs potencialmente homólogos) a fim de descobrir assinaturas funcionais. É desejável também poder varrer um genoma e identificar genes de ncRNAs. Porém, a predição da estrutura secundária de RNAs possui um espaço de soluções de tamanho exponencial no tamanho da seqüência, e estratégias utilizadas para a identificação de genes de proteínas freqüentemente falham quando utilizadas na identificação de ncRNAs. Conseqüentemente, a identificação in silico de ncRNAs é ainda um problema em aberto em bioinformática $[164,75,187]$.

Diferentes abordagens para a modelagem de ncRNAs têm sido propostas, cada uma mais apropriada para domínios específicos de problemas. Este capítulo apresenta uma revisão de métodos computacionais para problemas relacionados com ncRNAs. Devido à ampla literatura na área, o objetivo não foi realizar uma compilação exaustiva. Ao invés disso, foi realizada uma revisão das principais abordagens aplicadas até o momento, comentando alguns métodos e apontando os principais pontos fracos e fortes de cada uma dessas abordagens dependendo do domínio de problema.

A seção 2.1 define formalmente uma estrutura secundária de RNA a fim de facilitar a descrição dos métodos. A seção 2.2 apresenta os principais problemas envolvendo ncRNAs e as principais abordagens utilizadas para modelá-los. As seções 2.3 a 2.5 discutem cada problema separadamente. $\mathrm{O}$ apêndice $\mathrm{C}$ traz uma lista de todos os programas disponíveis e servidores web citados neste capítulo. 


\subsection{Definição formal de estrutura secundária}

Seja $x=x_{1} x_{2} \ldots x_{n}$ uma seqüência de RNA, onde $x_{i} \in\{\mathrm{A}, \mathrm{C}, \mathrm{G}, \mathrm{U}\}$ para $i=1, \ldots, n$.

Definição 1 Uma estrutura secundária de $x$ é um conjunto de pares de bases $P=\{(i, j) \mid i<j\}$ com as seguintes restrições [44]:

1. se $(i, j) \in P$ então $\left(x_{i}, x_{j}\right) \in\{(G, C),(C, G),(A, U),(U, A),(G, U),(U, G)\}$

2. $s e(i, j) \in P$ e $(i, \ell) \in P$ então $j=\ell$

3. $s e(i, j) \in P$ e $(k, j) \in P$ então $i=k$

4. se $(i, j) \in P$ então $j-i>\theta$, onde $\theta \in \mathbb{N}^{*}$

5. se $(i, j) \in P$ e $(k, l) \in P$ e $i<k<j$ então $i<k<l<j$.

Considerando esta definição, dois pares de bases empilhados em uma hélice são da forma $(i, j)$

e $(i+1, j-1)$. A restrição 4 define o tamanho mínimo $\theta$ de um hairpin loop. Os pseudo-nós e as triplas de bases são considerados interações terciárias, e não secundárias, por violarem algumas das restrições definidas acima. Pseudo-nós violam a restrição 5 (pois há cruzamento de hélices) e triplas de bases violam as restrições 2 ou 3 (pois há três bases envolvidas em uma mesma interação.

\subsection{Problemas e abordagens gerais na pesquisa de ncRNAs}

\subsubsection{Três principais problemas}

A pesquisa de ncRNAs envolve três principais tipos de problemas:

- predição de estrutura secundária;

- comparação de estrutura secundária e

- identificação de RNAs não codificantes.

Um ncRNA normalmente requer uma estrutura tri-dimensional específica para desempenhar sua função [241, 265]. Uma vez que a estrutura tri-dimensional é determinada pela estrutura secundária, a última é utilizada como aproximação no estudo da relação estrutura-função. A estrutura secundária, por sua vez, é definida pela sequiência primária. Portanto, ferramentas para predizer a estrutura secundária a partir de uma seqüência de RNA são úteis para estudar sua função. Quando um conjunto de RNAs homólogos é conhecido, sua estrutura secundária consenso pode ser predita 
com mais confiabilidade. Além disso, a conservação de domínios estruturais em diferentes espécies constitui evidência adicional de que estes domínios estão relacionados com a função específica destas seqüências. Portanto, a predição de estruturas conservadas são úteis para descobrir e caracterizar assinaturas de uma família específica de RNAs.

A comparação de estruturas pode servir a muitos propósitos. Por exemplo, ela pode ser utilizada para classificar um RNA como membro de uma família comparando sua estrutura com a estrutura consenso das várias famílias conhecidas. Além disso, se a função de um único RNA ou de uma família não é conhecida, ela pode ser inferida comparando a estrutura desse RNA (ou consenso no caso de uma família) com um banco de dados de assinaturas estruturais anotadas funcionalmente. A comparação de estruturas pode também ser utilizada para detectar a ocorrência de diferentes estruturas estáveis de uma mesma molécula (o que pode indicar a presença de alterações conformacionais possivelmente relacionadas com a função do RNA), para predizer mutações em uma seqüência de RNA que causam rearranjos na estrutura secundária e para comparar um conjunto de estruturas para escolher um representante.

Finalmente, predição e comparação de estruturas, além de outros tipos de análises, podem ser utilizadas para buscar ncRNAs em genomas, tanto através de buscas de RNAs homólogos a um candidato específico ou de ncRNAs em geral, incluindo novas famílias ainda desconhecidas.

Os métodos descritos neste trabalho são classificados de acordo com estes três problemas. Para cada um deles, muitos métodos não consideram pseudo-nós. Embora a predição destas estruturas seja desejável, o problema geral de predição de pseudo-nós é ainda computacionalmente inviável, devido à sua complexidade exponencial no tamanho da seqüência [169]. Métodos que lidam com esse problema impõem restrições na estrutura do pseudo-nó a ser detectado a fim de tornar o problema tratável, mas podem ainda ser práticos apenas para seqüências curtas [210, 218]. Durante a descrição dos métodos, aqueles que consideram pseudo-nós serão destacados e suas complexidades de tempo e memória serão mencionadas.

Complexidades de tempo e memória são também mencionadas quando esta informação for uma questão relevante de diferenciação entre métodos alternativos para um problema específico (seção 2.3.2).

\subsubsection{Três principais abordagens}

Ao lidar com um problema específico de RNAs, estratégias ab initio e comparativas podem ser aplicadas. Métodos ab initio, no contexto desta revisão, lidam com uma única seqüência, enquanto métodos comparativos analisam um conjunto de seqüências. Três principais abordagens podem ser aplicadas ao problema: termodinâmica, probabilística e covariação. Independentemente da 
estratégia a ser utilizada, um método pode utilizar uma ou mais abordagens para modelar um problema de RNAs. Abordagens termodinâmicas e probabilísticas podem ser exploradas tanto por estratégias ab initio quanto comparativas. Análise de covariação, porém, pode ser aplicada apenas em métodos comparativos. Cada abordagem assume diferentes hipóteses. Portanto, métodos baseados na mesma abordagem compartilham pontos fracos e fortes. Uma vez que estas abordagens não são mutuamente exclusivas, a combinação destas pode diminuir suas limitações individuais.

Abordagem termodinâmica Esta abordagem é baseada no valor de energia livre de Gibbs de estruturas de RNAs [267]. A energia livre de uma estrutura de RNA é computada utilizando o modelo do "vizinho mais próximo". Este modelo considera que a energia associada a um motivo estrutural é dependente apenas dos nucleotídeos deste motivo e das interações entre nucleotídeos adjacentes [267]. Por exemplo, a energia associada a um par de bases é diferente se este par está no final ou no meio de uma hélice. O modelo do "vizinho mais próximo" é então composto por um conjunto de parâmetros definindo a energia associada a uma variedade de interações vizinhas. Estes parâmetros termodinâmicos têm sido experimentalmente estimados desde 1971 [264] e continuam sendo aperfeiçoados [175]. Porém, estas medidas ainda carregam erros experimentais e de precisão que limitam a exatidão da predição estrutural a aproximadamente 50-75\% [77]. Esforços para estimar estes parâmetros termodinâmicos estatisticamente utilizando bancos de dados de estruturas de RNAs têm mostrado resultados promissores [62].

Abordagem probabilística Esta abordagem assume a existência de uma distribuição de probabilidades sobre o conjunto sendo caracterizado, podendo este ser de seqüências, estruturas ou alinhamentos. Modelos probabilísticos são construídos estimando parâmetros de um conjunto de exemplos conhecidos, chamado amostra de treinamento. A vantagem desta abordagem é a utilização de um arcabouço teórico bem definido para realizar estatísticas sobre o espaço de soluções. Além disso, diferentes modelos probabilísticos podem ser desenhados para modelar características diferentes. Esta flexibilidade permite a construção de modelos para famílias específicas de RNAs [69], o que é particularmente importante para classificação de seqüências. Modelos sofisticados podem ser desenhados, mas suposições erradas podem levar a modelos que fornecem resultados ruins. Além disso, o incremento no nível de sofisticação pode vir acompanhado de incremento no número de parâmetros a serem estimados. Isto pode exigir maiores amostras de treinamento, muitas vezes não disponíveis. Finalmente, uma amostra de treinamento tendenciosa pode levar a um modelo tendencioso. Portanto, a qualidade do modelo estimado depende não apenas do desenho do modelo mas também do tamanho e da qualidade da amostra de treinamento disponível. 
Análise de covariação Espera-se que RNAs homólogos possuam uma função comum, e também espera-se que possuam estruturas similares e alguma similaridade de seqüência. Ao comparar duas ou mais seqüências de RNAs homólogos, se duas bases hipoteticamente pareadas em uma seqüência (G-C, por exemplo) forem diferentes em outras seqüências mas ainda constituindo um par de bases válido para a formação de uma hélice (como A-U), isto pode ser considerado evidência de pressão seletiva. Portanto, este fato pode ser utilizado como evidência para a existência daquele pareamento na estrutura secundária [128]. Mutações duplas preservando um pareamento são conhecidas como mutações compensatórias, e o processo de detecção destas mutações é chamado análise de covariação. Para detectar essas mutações compensatórias, alguns métodos modelam cada posição de seqüência como uma variável aleatória e calculam a informação mútua de cada par de variáveis aleatórias. Convém notar, porém, que não é necessário que duas bases covariem, uma vez que algumas mutações pontuais, tais como G-U para G-C, são ainda evidência de pareamento. Portanto, métodos que apenas procuram covariação podem perder informações valiosas. A principal vantagem de análise de covariação é o aproveitamento de informação de toda uma família de seqüências ao invés de apenas uma seqüência. Porém, mutações compensatórias são freqüentemente detectadas em colunas de um

alinhamento múltiplo. Para que a deteç̧ão tenha sucesso, as seqüências sendo analisadas precisam ser conservadas o suficiente para permitir um alinhamento múltiplo preciso e distintas o suficiente para revelar covariações [128]. Erros no alinhamento múltiplo devem afetar a precisão dos métodos. Outra óbvia desvantagem é que análise de covariação não consegue lidar com sequiências isoladas. Outras desvantagens são específicas de cada problema de RNA, sendo descritas nas seções 2.3 a 2.5.

\subsection{Predição de estrutura secundária}

Dada uma seqüência de RNA, o número de possíveis estruturas secundárias cresce exponencialmente com o tamanho da seqüência [284]. A questão é como percorrer este espaço de soluções exponencial a fim de escolher a melhor estrutura. Quando a estrutura secundária de apenas uma seqüência de RNA precisa ser predita, somente métodos ab initio podem ser utilizados. Se há a disponibilidade de um conjunto de RNAs homólogos, métodos comparativos podem predizer a estrutura consenso com mais precisão [128].

\subsubsection{Métodos ab initio: predição de uma única seqüência}

\section{Preditores termodinâmicos}

Preditores termodinâmicos exploram a hipótese de que uma molécula de RNA é dobrada na estrutura termodinamicamente mais estável, isto é, aquela possuindo a energia livre mínima (ELM). 
Uma abordagem direta seria enumerar todas as possíveis estruturas e então selecionar aquela com o valor mínimo de energia livre [205], mas a complexidade exponencial no tamanho da seqüência do tempo gasto na etapa de enumeração só é factível para as seqüências mais curtas. Para lidar com esta questão de complexidade, os métodos atuais utilizam um método de programação dinâmica desenvolvido por Nussinov et al. [195] que reduz a complexidade de tempo para $O\left(n^{3}\right)$, onde $n$ é o tamanho da seqüência. Porém, a estrutura de ELM pode não ser a correta. Além da existência de erros nos parâmetros termodinâmicos e de regras termodinâmicas desconhecidas, a estrutura de ELM pode não ser aquela adotada pelo RNA. A estrutura correta pode estar entre aquelas com valores sub-ótimos de energia [111]. Neste caso, a análise do conjunto de possíveis estruturas (espaço de estruturas) pode fornecer dicas sobre as estruturas e os motivos estruturais mais prováveis. Finalmente, algoritmos podem ser baseados na hipótese de que uma molécula de RNA pode assumir a estrutura mais fácil de ser formada devido a armadilhas cinéticas no processo de dobramento.

\section{Energia Livre Minima}

Alguns dos programas que computam a estrutura secundária de energia livre mínima são MFOLD [300, 302], RNAfold [114], RNASTRUCTURE [175], PKNOTS [218] e pknotsRG [210, 242].

Em particular, os últimos dois métodos incluem a predição de pseudo-nós. Ambos impõem restrições no tipo de pseudo-nós encontrados a fim de reduzir a complexidade teórica do problema, PKNOTS sendo mais geral (complexidade de tempo e memória de $O\left(n^{6}\right)$ e $O\left(n^{4}\right)$, respectivamente) e pknotsRG mais restritivo $\left(O\left(n^{4}\right) \text { para tempo e } O\left(n^{2}\right) \text { para memória }\right)^{1}$.

\section{Análise do espaço de estruturas}

Métodos que realizam análise do espaço de estruturas exploram estruturas sub-ótimas a fim de criar um perfil mais preciso de quais tipos de estruturas (ou sub-estruturas) são mais prováveis de ocorrer em situações reais.

A fim de analisar eficientemente o espaço de estruturas, a maioria dos métodos utiliza a distribuição de Boltzmann para modelar a probabilidade de uma estrutura $S$. Esta probabilidade é dada pela equação:

$$
P_{S}=\frac{\exp \left(-E_{S} / R T\right)}{Z(T)}
$$

\footnotetext{
${ }^{1}$ Note que o sucesso de métodos termodinâmicos que procuram lidar com pseudo-nós é limitada, especialmente porque os dados experimentais são ainda escassos para uma boa estimação de parâmetros termodinâmicos de pseudonós.
} 
onde $E_{S}$ é a energia livre da estrutura $S, R$ é a constante dos gases, $T$ é a temperatura de dobramento do RNA em Kelvin e $Z(T)$, conhecida como função de partição, é:

$$
Z(T)=\sum_{S^{\prime}} \exp \left(-E_{S^{\prime}} / R T\right)
$$

que é calculada utilizando programação dinâmica, isto é, sem enumerar todas as possíveis estruturas $S^{\prime}$.

Esta probabilidade $P_{S}$ da estrutura pode ser utilizada para extrair outras informações. McCaskill [178] propôs uma fórmula para estimar a probabilidade de quaisquer dois nucleotídeos em diferentes posições estarem pareados em uma estrutura secundária. A probabilidade de duas bases nas posições $i$ e $j$ de uma molécula estarem pareadas é dada por:

$$
P_{i j}=\sum_{(i, j) \in S} P_{S}
$$

Estes valores compõem a matriz termodinâmica de probabilidades de pareamentos, que pode ser analisada a fim de detectar hélices bem definidas. Esta matriz é calculada pelos programas RNAfold [114] e RNASTRUCTURE [175].

O programa NUPACK $[65,66]$ utiliza uma função de partição mais geral que é capaz de incluir uma classe de pseudo-nós fisicamente relevantes, porém exigindo $\mathrm{O}\left(n^{5}\right)$ no tempo ${ }^{2}$.

A distribuição de Boltzmann pode ser utilizada para calcular uma partição do espaço de estruturas por intervalos de valores de energia em uma abordagem conhecida como densidade de estados $[41,44,55]$. Estados ${ }^{3}$ que são densos em estruturas podem indicar estruturas intermediárias mais prováveis. Em particular, algumas destas estruturas podem ser "armadilhas cinéticas" formadas durante o processo de dobramento/desdobramento [40].

Se todas as estruturas em um intervalo energético específico são enumeradas, várias estatísticas podem ser calculadas, tais como o cálculo dos motivos estruturais mais prováveis ou a construção de agrupamentos de estruturas. RNAsubopt [291] foi pioneiro nesta enumeração exaustiva. Este programa gera todas as estruturas sub-ótimas que possuem energia em um intervalo (definido pelo usuário) a partir da ELM. Para compensar o número excessivamente grande de tais estruturas para seqüências longas, Sfold [32, 63,64] produz uma amostra do espaço completo de estruturas utilizando a distribuição de Boltzmann. Análises podem agora ser realizadas sobre esta amostra, uma vez que esta possui, teoricamente, a mesma distribuição do espaço completo de estruturas. Este programa também identifica clusters das estruturas amostradas, baseado em similaridade estrutural, e seleciona um representante de cada cluster, chamado centróide. O centróide é a estrutura tendo

\footnotetext{
${ }^{2} \mathrm{O}$ algoritmo de McCaskill exige $O\left(n^{3}\right)$ de tempo sem considerar pseudo-nós [178].

${ }^{3} \mathrm{Um}$ estado é uma parte desta partição, correspondente a um único intervalo de energia.
} 
a distância mínima (em termos de número de pares de bases) para todas as outras estruturas do cluster. O programa retorna a estrutura de ELM, os centróides dos clusters e o centróide do espaço de estruturas (isto é, o centróide para todas as estruturas amostradas).

Muitas estruturas alternativas compartilham o mesmo padrão estrutural, ou forma ${ }^{4}$. Portanto, a forma pode também ser utilizada para produzir uma partição do espaço de estruturas de uma particular molécula de RNA. RNAshapes [252, 276] realiza uma partição das formas e associa a cada forma um valor de probabilidade consistindo da soma das probabilidades de Boltzmann de todas as estruturas na parte correspondente. RNAshapes também fornece a estrutura de ELM para cada $\operatorname{parte}^{5}$.

A última abordagem de análise do espaço de estruturas é utilizada pelo MFOLD [299]. Ao invés de utilizar a distribuição de Boltzmann, computa a quantidade $h$-num(i,j), uma medida aplicada a pares de posições em uma molécula de RNA que indica o nível de promiscuidade de pareamento entre as bases nas posições $i$ e $j$. Espera-se que pareamentos bem determinados tenham valores baixos de $h$-num [301].

\section{Dobramento cinético}

Algoritmos cinéticos são baseados na hipótese de que a estrutura final de uma molécula de RNA depende apenas de fatores locais ao invés de globais. Em outras palavras, durante o processo de dobramento, sub-estruturas ótimas podem se formar, atuando como armadilhas cinéticas e evitando que a estrutura globalmente ótima seja alcançada.

Uma abordagem comum é construir a estrutura completa a partir de hélices individuais. Abrahams et al. [1] desenvolveram um algoritmo que primeiro encontra todas as possíveis hélices e então constrói incrementalmente a estrutura final selecionando, em cada passo, a hélice que minimiza a energia livre da estrutura corrente, permitindo a introdução de pseudo-nós. Schmitz e Steger desenvolveram um algoritmo similar [240], mas permitindo a remoção de hélices da estrutura corrente quando a estrutura recém-formada leva à formação de pseudo-nós ou sobreposições (bases participando em diferentes hélices). RDfolder [295] utiliza uma abordagem de Monte Carlo para implementar uma variação do segundo algoritmo: o ciclo básico de construção da estrutura é executado várias vezes, selecionando aleatoriamente as hélices a serem adicionadas, mas não permitindo remoção de hélices. Se a seqüência é pequena (até 150 bases), a estrutura predita é a mais freqüente dentre

\footnotetext{
${ }^{4}$ Nós podemos informalmente definir uma forma como uma aparência visual da estrutura, como um formato de "trevo de quatro folhas", uma sucessão particular de hélices, etc.

${ }^{5}$ Estes dois componentes, energia do representante e probabilidade da forma, não são redundantes, uma vez que a forma que possui o representante ótimo não é necessariamente a mais provável.
} 
todas as execuções. Para seqüências maiores, visando evitar um incremento exponencial no número de simulações, o programa contabiliza a freqüência de cada hélice (ao invés da estrutura inteira) e então constrói a estrutura final selecionando incrementalmente as hélices mais freqüentes que são compatíveis com a estrutura parcial.

RNAKinetics [57] vai além e considera o fato de que as moléculas de RNA podem iniciar o processo de dobramento durante a transcrição [183]. Desta forma, a taxa e a direção da transcrição são levadas em consideração ao calcular as hélices a serem adicionadas ou removidas da estrutura. A simulação de dobramento é parametrizada associando variáveis aleatórias para computar o número de passos de simulação e o incremento de tempo utilizado na simulação de dobramento. O programa apresenta a lista das estruturas mais prováveis ordenadas pelos seus instantes de vida.

Uma abordagem de Monte Carlo diferente é trabalhar em um nível de granularidade menor, simulando a formação e a ruptura de pares de bases individuais ao invés de hélices completas. Esta estratégia é adotada em Kinfold [87], que modela o dobramento de RNA como um processo de Markov no espaço de estruturas.

HotKnots [215] adota a estratégia de poda do espaço inicial de hélices utilizada para construir incrementalmente as estruturas de RNA. Nesta abordagem, somente conjuntos de hotspots promissores são utilizados. Um hotspot é uma sub-estrutura semelhante a uma hélice composta de pares de bases empilhados podendo conter bojos de uma base e loops internos simétricos de duas bases. Um conjunto de hotspots é promissor se a diferença da ELM das estruturas restritas pelos hotspots é no máximo $80 \%$ maior que a ELM da estrutura não restrita. Este programa também prediz pseudo-nós.

\section{Um modelo probabilístico}

Diferente da abordagem termodinâmica onde os parâmetros são estimados experimentalmente, em modelos probabilísticos é possível estimar os valores dos parâmetros para diferentes famílias de RNA utilizando dados de bancos de estruturas de RNA. Como esta estimação é automática e rápida, diferentes modelos podem ser construídos e testados a fim de explorar diferentes características na modelagem de estruturas de RNA.

CONTRAfold [67] é um programa que utiliza Modelos Condicionais Log Lineares (MCLLs), uma generalização de Gramáticas Livres de Contexto Estocásticas (GLCEs). Este modelo é marcado por três principais inovações: treinamento de um modelo discriminativo, parametrização flexível e uma otimização ajustável pela precisão. MCLLs parametrizam a probabilidade condicional de uma estrutura dada uma seqüência como uma função log linear dos parâmetros do modelo. Considera-se que este modelo discriminativo tem um poder de predição superior ao dos modelos 
gerativos, que descrevem uma probabilidade conjunta das seqüências e estruturas. Ao invés de utilizar parâmetros associados às probabilidades das regras gramaticais, são utilizados parâmetros associados a treze características estruturais, tais como pares de bases, tamanhos de hairpins, hélices, bojos e loops internos e assimetrias de loops internos. Finalmente, a estrutura predita não é a que maximiza o escore da estrutura, mas a que maximiza a precisão esperada. Esta precisão é uma combinação, definida pelo usuário, entre sensitividade e especificidade de predições de pareamentos.

\section{Outras abordagens}

Diferentes estratégias podem ser combinadas na tentativa de melhorar a qualidade das predições estruturais.

A teoria dos grafos pode ser utilizada para maximizar escores utilizados para avaliar possíveis estruturas secundárias para diferentes sistemas de escore. Maximum Weighted Matching (MWM) [258] é um programa baseado em grafos que pode ser utilizado para predizer tanto a estrutura de uma única seqüência quanto a estrutura consenso de múltiplas seqüências, incluindo pseudo-nós ${ }^{6}$. Um grafo é construído com nós representando bases e arestas representando possíveis pareamentos. As arestas possuem pesos de acordo com algum sistema de escore, como termodinâmico ou valores de probabilidade (figura 2.1). Estruturas secundárias candidatas são subgrafos matching, isto é, subgrafos que possuem nós conectados a no máximo um outro nó. A estrutura ótima pode ser encontrada buscando o subgrafo de matching que tem o maior peso total de arestas. MWM pode também ser utilizado para detectar triplas de base.

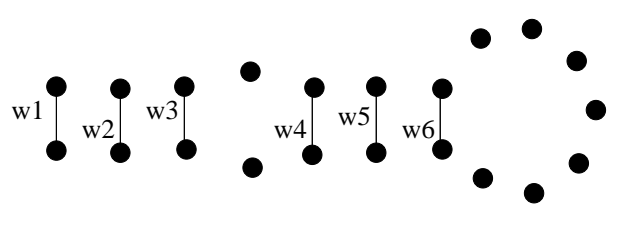

Figura 2.1: Grafo representando uma estrutura secundária de RNA. Nós são bases e arestas representam pareamentos. Os valores $w 1 \ldots w 6$ são pesos atribuídos às arestas.

O algoritmo de programação dinâmica de Nussinov foi desenvolvido para maximizar o número de pares de bases na estrutura predita [195]. O mesmo esquema simples de escore pode ser utilizado com as idéias de Análise Cinética e Análise do Espaço de Estruturas, fora do contexto de termodinâmica ${ }^{7}$. Iterated Loop Matching (ILM) $[225,226]$ executa o algoritmo original de

\footnotetext{
${ }^{6}$ Complexidade de tempo e memória de $O\left(n^{3}\right)$ e $O\left(n^{2}\right)$, respectivamente.

${ }^{7} \mathrm{Na}$ verdade estas medidas são relacionadas, uma vez que a energia de uma estrutura depende, entre outras características, do número de pares de bases dessa estrutura.
} 
Nussinov iterativamente. Em cada iteração a melhor hélice é selecionada para a estrutura final e removida da seqüência para a próxima iteração. Uma vez que os hairpin-loops (região não pareada) não são removidos, o algoritmo pode detectar pseudo-nós ${ }^{8}$. Apesar de não haver garantia de otimalidade, ILM tem mostrado resultados melhores que os do MWM. RNALOSS [45] também utiliza maximização do número de pares de bases. Estes parâmetros são utilizados com a distribuição de Boltzmann para realizar uma análise de densidade de estados.

\subsubsection{Método comparativos}

Quando se busca a melhor estrutura consenso para uma família de ncRNAs, a situação ideal seria ter estruturas secundárias validadas biologicamente para cada seqüência, e então calcular a estrutura consenso. Infelizmente, o número de estruturas validadas é bem pequeno. A maioria das estruturas disponíveis são resultados de predições. Neste contexto, a melhor situação é quando o conjunto de seqüências é similar o suficiente para que um alinhamento múltiplo seja produzido, e divergente o suficiente para mostrar covariações. Se este alinhamento adequado não pode ser produzido mas há a disponibilidade de estruturas (validadas ou preditas) para estas moléculas, esta informação pode ser utilizada na busca pela estrutura consenso. Uma alternativa é simplesmente considerar as seqüências primárias e construir a estrutura consenso do zero. Seguindo essas possibilidades, os preditores de estrutura comparativos serão classificados em três grupos de acordo com a entrada que eles recebem:

1. seqüências alinhadas e não dobradas,

2. seqüências não alinhadas e individualmente dobradas e

3. seqüências não alinhadas e não dobradas.

\section{Predição de seqüências alinhadas e não dobradas}

Uma vez que se tenha um alinhamento múltiplo, pode-se aplicar uma estratégica de busca por covariações. Outras informações podem também ser utilizadas para associar peso a estes dados de covariação, tais como dados filogenéticos e termodinâmicos.

\footnotetext{
${ }^{8} \mathrm{~A}$ complexidade de tempo do pior caso e do caso médio são, respectivamente, $O\left(n^{4}\right)$ e $O\left(n^{3}\right)$.
} 


\section{Métodos utilizando apenas covariação}

Se um sistema de escore, como informação mútua, é utilizado para descrever covariações, métodos como o algoritmo de Nussinov [195], Maximum Weighted Matching [258] ou Iterated Loop Matching [225, 226] - todos utilizados para predizer a estrutura secundária de uma única molécula (seção 2.3.1) - podem ser aplicados para detectar a estrutura secundária consenso ótima [80]. Neste caso, os algoritmos precisam considerar colunas do alinhamento múltiplo ao invés de posições de nucleotídeos individuais de uma única seqüência.

\section{Utilização de informação filogenética}

Sistemas de escore baseados somente em covariações não levam em consideração a informação filogenética envolvendo essas covariações. Esta informação é utilizada na abordagem conhecida como Tree Model [102]. Uma árvore filogenética e matrizes de taxas de mutação (para pares de bases e bases não pareadas) são utilizadas para computar a probabilidade a posteriori de duas colunas estarem pareadas ou não. Árvores filogenéticas podem discriminar melhor entre pares de colunas com forte ou fraca evidência de pareamento. Esta discriminação vem da ordem evolutiva das seqüências imposta pela árvore. Esta ordem revela o número mínimo de eventos de mutações compensatórias em cada coluna. Se, por exemplo, dois pares de colunas têm o mesmo número de pares G-C e A-U, a árvore pode indicar diferentes números de eventos de mutações. Quanto maior o número de eventos de mutações exigidos, mais forte é a evidência de pareamento. Por causa desta sensitividade extra, o Tree Model tem um desempenho melhor do que o de outros métodos baseados exclusivamente em covariações.

Akmaev et al. [3] também utilizaram modelos filogenéticos para propor um conjunto de estatísticas para decidir se duas colunas de um alinhamento múltiplo estão pareadas ou não. A abordagem de Akmaev, porém, é estendida para triplas de bases.

Uma terceira abordagem filogenética é adotada pelo Pfold [141, 142], que combina um modelo evolucionário de seqüências de RNA com um modelo probabilístico de estruturas secundárias. Estes são utilizados para calcular uma árvore filogenética e uma estrutura consenso de um alinhamento múltiplo. O modelo evolucionário consiste de um conjunto de probabilidades de nucleotídeos e taxas de mutação para bases pareadas e não pareadas, todas estimadas de uma grande amostra de RNAs. O modelo probabilístico é uma gramática livre de contexto estocástica estimada da mesma amostra de RNAs (estruturados) utilizada para estimar as taxas de mutação. Pfold alcança resultados razoáveis mesmo utilizando apenas duas seqüências.

Baseado na mesma idéia de Pfold, RNA-Decoder [201] vai além e estima modelos filogenéticos e 
probabilísticos para seqüências codificantes e não codificantes de proteína. O modelo filogenético é construído utilizando diferentes sub-modelos para regiões codificantes e não codificantes, caracterizando, em particular, as diferentes taxas de mutação nas três posições de um códon devido à pressão seletiva para conservação de aminoácidos em regiões codificantes. Em particular, RNA-Decoder pode ser utilizado para varrer alinhamentos de genomas inteiros (virais, por exemplo) ou então de RNAs mensageiros para identificar possíveis estruturas secundárias conservadas com menos falsos positivos do que quando utilizando outros métodos [201].

\section{Utilização de informação termodinâmica}

Alguns métodos também exploram informação termodinâmica em suas análises. X2 [132] utiliza uma combinação linear de valores de covariação, termodinâmica e heurística para ordenar pares de colunas de um alinhamento múltiplo. O termo termodinâmico é baseado na energia do par de bases mais estável em um par de colunas ${ }^{9}$. O termo heurístico controla a distância entre bases pareadas próxima a um valor ótimo, favorecendo pareamentos locais. As regiões de maior escore de pareamento são incluídas na estrutura final progressivamente, de acordo com a ordem dos escores e não permitindo sobreposição. Esta montagem permite a formação de pseudo-nós.

ConStruct [165] combina todas as matrizes termodinâmicas de probabilidades de pareamentos (seção 2.3.1 equação 2.3) em uma matriz consenso, que é então utilizada para fornecer a estrutura consenso mais provável termodinamicamente. Para calcular esta matriz consenso, gaps são inseridos nas matrizes individuais guiadas pelos gaps no alinhamento múltiplo. Estas matrizes, agora com a mesma dimensão, são combinadas utilizando uma equação que considera pesos para as seqüências, de forma a evitar sobre-representação de seqüências altamente similares. Para aliviar o impacto de erros de alinhamentos, a estrutura consenso e o alinhamento de seqüências são graficamente apresentados para o usuário, que pode ajustar manualmente o alinhamento. Se houver tal ajuste, o novo alinhamento de seqüências gera um novo alinhamento de matrizes, reiniciando o processo. Uma vez que covariações não são analisadas, ConStruct pode detectar uma estrutura consenso mesmo em regiões altamente conservadas.

RNAalifold [116] combina covariação e termodinâmica em um sistema de escore a ser utilizado diretamente no algoritmo de programação dinâmica para predição de estrutura ótima. Isto é, a matriz de programação dinâmica é calculada apenas uma vez para o alinhamento inteiro. Se as seqüências de entrada não possuem uma estrutura em comum, nenhuma estrutura é fornecida.

Como tanto o RNAalifold quanto o ConStruct possuem uma matriz consenso, eles podem ser

\footnotetext{
${ }^{9}$ Opcionalmente, este termo pode ser calculado como sendo a energia média de todos os pareamentos do par de colunas.
} 
utilizados para calcular estruturas sub-ótimas, probabilidades de pares de bases e realizar análise do espaço de estruturas, ao invés de apenas predizer a estrutura ótima.

X2 e RNAalifold combinam explicitamente fontes específicas de informação em um único sistema de escore utilizando pesos pré-determinados. BayesFold [140] propõe uma estratégia bayesiana para combinar qualquer tipo e número de fontes de informação, sem depender de escolhas arbitrárias de $\operatorname{pesos}^{10}$. Inicialmente RNAsubopt é utilizado para produzir uma primeira lista de estruturas candidatas $\left(\left\{H_{k}\right\}_{k=1}^{n}\right)$. Uma distribuição de probabilidades uniforme é atribuída a estes primeiros candidatos, servindo como uma fonte inicial de informação $\left(D_{0}\right)$. Então, a cada estrutura $\left(H_{i}\right)$, é atribuída uma probabilidade combinada utilizando as diferentes fontes $\left(D_{j}\right)$ de informação através da aplicação seqüencial da fórmula de Bayes:

$$
P\left(H_{i} \mid D_{j+1}\right)=P\left(H_{i} \mid D_{j}\right) P\left(D_{j+1} \mid H_{i}\right) /\left(\sum_{k} P\left(H_{k} \mid D_{j}\right) P\left(D_{j+1} \mid H_{k}\right)\right),
$$

Em outras palavras, a probabilidade de uma estrutura dada uma fonte de informação é combinada à probabilidade da mesma estrutura dada uma outra fonte de informação, considerando a primeira como uma informação a priori para o cálculo da segunda, e assumindo que todas as fontes de dados são independentes.

\section{Predição de seqüências não alinhadas e dobradas}

Quando a entrada é um conjunto de seqüências dobradas mas não alinhadas, o desafio é produzir um alinhamento estrutural destas seqüências, detectando a estrutura consenso de uma família de estruturas de RNAs. Para alinhamento estrutural múltiplo, o problema é similar ao de alinhamento múltiplo padrão de seqüências de DNA: computar o alinhamento múltiplo ótimo é um problema de complexidade exponencial no número de seqüências. Neste espírito, todas as abordagens têm dois algoritmos, o algoritmo para alinhar duas seqüências e a estratégia heurística para executar alinhamentos múltiplos incrementalmente, alinhando duas seqüências ou consensos parciais de cada vez.

Uma estrutura de RNA pode ser representada como uma árvore ${ }^{11}$. Então, alinhar duas estruturas pode ser traduzido no problema de alinhar duas árvores [131]. Se cada estrutura secundária local for descrita por uma árvore, o problema de alinhar duas estruturas é então traduzido para o problema de alinhar duas florestas de árvores. Esta é a abordagem utilizada por RNAForester [112]. A vantagem da abordagem de florestas é que os alinhamentos agora possuem um sabor "local",

\footnotetext{
${ }^{10}$ Apesar deste método possuir um esquema flexível para combinar fontes de dados, ele foi implementado para inicialmente combinar valores termodinâmicos, de informação mútua e de mapas químicos.

${ }^{11}$ Esta árvore utiliza nós para representar pareamentos e folhas para representar nucleotídeos não pareados.
} 
permitindo que o programa encontre sub-estruturas similares quando as estruturas globais são divergentes, e portanto detectando motivos conservados em duas estruturas de RNAs. RNAforester também executa alinhamento global de florestas [113, 211].

Outra possível representação de estrutura de RNAs é a de seqüências arco-anotadas, onde arcos conectam bases pareadas (figura 2.2). Alinhar duas estruturas nesta representação significa alinhar bases e arcos. RNA_align [130] realiza este alinhamento maximizando o escore de alinhamento calculado a partir de 8 possíveis eventos: 3 eventos para bases não pareadas (base-match, basemismatch e base-deletion) e 5 eventos para arcos e seus pares de bases (arc-match, arc-mismatch, arc-removing, arc-altering e arc-breaking, os últimos três sendo casos particulares de ruptura de um arco). Esses eventos estão representados na figura 2.2.

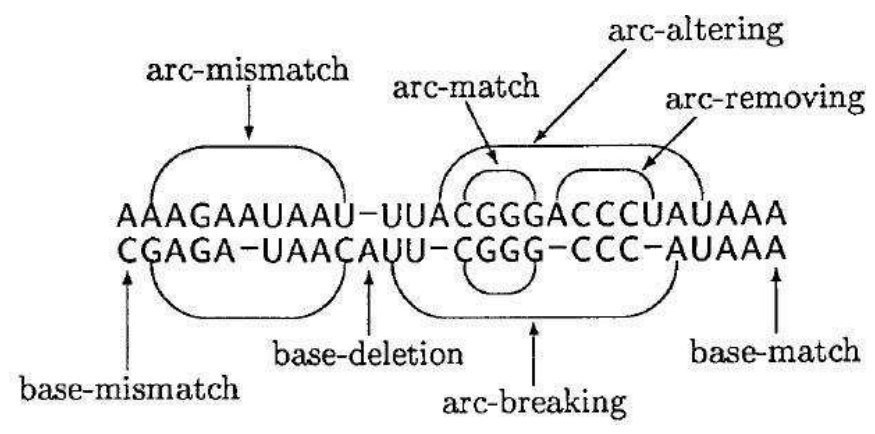

Figura 2.2: Seqüências arco-anotadas e as operações permitidas [130].

MARNA [248] executa um alinhamento estrutural múltiplo utilizando RNA_align para executar alinhamentos pairwise e T-Coffee [194] para executar o alinhamento múltiplo progressivo. Uma vez que o alinhamento múltiplo é produzido, uma variante do algoritmo de Nussinov [195] é utilizado para predizer a estrutura consenso que maximiza o número de pareamentos conservados em um número específico de seqüências. MARNA também aceita como entrada seqüências não dobradas. Neste caso, ele pode predizer uma estrutura para cada seqüência (estrutura de ELM) ou várias estruturas sub-ótimas (utilizando RNAshapes [252] ou um backtracking estocástico de RNAsubopt [114]).

\section{Predição de seqüências não alinhadas e não dobradas}

Alguns métodos recebem apenas as seqüências como entradas, sem qualquer informação adicional. Portanto, estes precisam dobrar e alinhar as seqüências de entrada. Alguns destes métodos realizam esta tarefa em dois passos, primeiro dobram e então alinham ${ }^{12}$, e outros executam as duas

\footnotetext{
${ }^{12}$ Um método pode também primeiro alinhar e então dobrar as seqüências. Porém, estes métodos normalmente utilizam um outro programa, CLUSTALW [90] por exemplo, para produzir um alinhamento múltiplo inicial. Por
} 
tarefas simultaneamente. Métodos de dois passos, apesar de parecerem similares àqueles do grupo 2 (predição de seqüências não alinhadas e dobradas), têm a vantagem de considerarem estruturas alternativas para cada seqüência de entrada. A proposta de alinhamento e predição estrutural simultâneos é a mais atrativa. Porém, sua desvantagem é a alta complexidade de tempo e de memória, exponencial no número de seqüências. Apesar de polinomial quando aplicado a duas seqüências, estes métodos são ainda caros em tempo e memória para aplicações reais. Simplificações e heurísticas são necessárias para lidar com esse problema.

\section{Métodos de dois passos}

Brevemente, estes métodos executam duas fases: primeira, a predição de um conjunto de estruturas para cada seqüência de entrada, normalmente utilizando valores termodinâmicos; segunda, a seleção de uma estrutura consenso baseada no conjunto de estruturas obtidas na primeira fase. A principal diferença entre os métodos reside na granularidade das estruturas iniciais (estruturas globais vs. locais) e na medida de similaridade utilizada para selecionar a estrutura conservada.

Alguns preditores consideram apenas a similaridade estrutural, não considerando a seqüência primária. Portanto, eles são adequados para comparar seqüências homólogas remotas que apresentam pouca conservação de seqüência primária. Exemplos são o método proposto por Bouthinon e Soldano [22] e o programa RNAGA [34].

O método descrito por Bouthinon e Soldano [22] encontra os conjuntos individuais de estruturas através da detecção de possíveis hélices. Uma combinação compatível dessas possíveis hélices representa uma possível estrutura. Para cada seqüência de entrada, somente as combinações com valores de energia livre abaixo de um limiar definido pelo usuário são computadas, e a combinação com o valor mais baixo de energia livre é selecionada. O conjunto dos maiores padrões estruturais (combinações de hélices) que ocorrem em pelo menos $q$ seqüências ( $q \leq n$, onde $n$ é o número de seqüências de entrada) é computado, representando as candidatas para a estrutura consenso. O algoritmo seleciona o padrão estrutural deste conjunto final que ocorre menos freqüentemente em seqüências aleatórias geradas por embaralhamentos das seqüências de entrada.

O programa RNAGA [34] utiliza dois algoritmos genéticos: o primeiro produz, para cada seqüência, um conjunto de estruturas globais; o segundo gera uma lista de estruturas consenso candidatas. Os dois algoritmos genéticos utilizam operadores que adicionam e removem hélices de acordo com algum critério. O primeiro algoritmo dá preferência para hélices que decrementam a energia de novos indivíduos, enquanto o segundo dá preferência para hélices com um alto escore de conservação

isso, este caso foi incluído na seção de predição de seqüências alinhadas e não dobradas. 
estrutural.

Como o número de possíveis estruturas cresce com o tamanho da seqüência, o número de estruturas comuns espúrias (ao acaso) também cresce [22]. Este efeito pode ser diminuído ao considerar a seqüência primária durante a comparação de estruturas. Os programas CARNAC [266] e comRNA [129] implementam esta estratégia utilizando regiões conservadas da seqüência primária como âncoras para restringir o alinhamento estrutural pairwise de todos os pares de seqüências de entrada. Destes alinhamentos, estes programas selecionam um conjunto $P$ de hélices conservadas pairwise, isto é, um conjunto

$$
P=\left\{\left(h_{i}^{A}, h_{j}^{B}\right) \mid h_{i}^{A} \in \text { seqüência } A, h_{j}^{B} \in \text { seqüência } B \text { e } h_{i}^{A} \text { e } h_{j}^{B} \text { são conservadas em } A \text { e } B\right\} \text {. }
$$

CARNAC e comRNA utilizam dois diferentes critérios para a construção deste conjunto, mas ambos requerem que as duas hélices conservadas estejam entre as mesmas âncoras. CARNAC exige que pelo menos uma mutação compensatória ocorra no par de hélices [202], enquanto comRNA compara as similaridades no tamanho, energia e seqüência das hélices e seqüência do hairpin-loop (bases não pareadas encerradas pela hélice). Os dois programas constroem um grafo onde cada hélice selecionada $h_{k}^{X}$ é representada como um nó e é conectada a um outro nó $h_{l}^{Y}$ se e somente se $\left(h_{k}^{X}, h_{l}^{Y}\right) \in P$. No grafo produzido por CARNAC, componentes $\operatorname{conexos}^{13}$ representam hélices conservadas que são candidatas a participarem da estrutura consenso final. Estes componentes recebem um escore baseado em características topológicas tais como o número de nós e arestas, uma vez que estas características indicam o nível de conservação de hélices entre todas as seqüências. A estrutura final é construída utilizando uma abordagem gulosa adicionando hélices compatíveis ${ }^{14}$ representada pelos componentes conexos com melhores escores. Portanto, hélices não precisam ser conservadas em todas as seqüências. O grafo do comRNA é um grafo $m$-partido ${ }^{15}$, onde cada partição é formada por nós da mesma seqüência e $m$ é o número de seqüências de entrada. Uma hélice conservada em pelo menos $k$ seqüências é um clique que possui pelo menos $k$ nós ${ }^{16}$. Portanto, o programa procura todos os cliques maximais de tamanho pelo menos $k$. Os maiores cliques são selecionados para compor a

\footnotetext{
${ }^{13}$ Os componentes conexos de um grafo são as classes de equivalência de nós sob a relação "é alcançável por" [51]. Ou seja, cada nó de um componente conexo possui pelo menos uma aresta que o conecta a outro nó desse componente.

${ }^{14}$ Duas hélices são consideradas compatíveis se elas não se sobrepõem nem formam uma estrutura de pseudo-nó.

${ }^{15} \mathrm{Um}$ grafo $m$-partido é um grafo onde o conjunto de nós pode ser dividido em $m$ conjuntos disjuntos de tal forma que cada aresta conecte um nó em um conjunto e um nó em um conjunto diferente.

${ }^{16} \mathrm{Um}$ clique é um subgrafo completo, isto é, um subgrafo no qual todos os nós são conectados a todos os outros nós do subgrafo.
} 
estrutura final, permitindo a formação de pseudo-nós ${ }^{17}$.

Se por um lado a similaridade baseada apenas em estrutura leva a estruturas consenso espúrias, por outro lado a dependência de conservação da seqüência primária é uma armadilha quando se lida com seqüências muito divergentes. Atacando essa questão, RNAscf [7] utiliza hélices conservadas como âncoras, e seqüência primária apenas como informação adicional. O passo inicial consiste em descartar hélices pequenas e espúrias selecionando, para cada seqüência, todas as possíveis hélices com um tamanho mínimo e com um valor termodinâmico que não exceda um limiar pré-definido. Hélices compatíveis conservadas em todas as seqüências são utilizadas como âncoras no alinhamento múltiplo. Cada hélice âncora gera um conjunto de blocos de alinhamento: blocos para as hélices e blocos para as regiões não pareadas entre os lados das hélices. Cada bloco é globalmente alinhado de acordo com uma mistura de escores termodinâmicos e de similaridade, mas utilizando diferentes valores de escore para blocos vindo de regiões pareadas e não pareadas.

\section{Alinhamento e predição de estrutura simultâneos}

O problema de alinhamento e predição de estrutura simultâneos é um problema de otimização, onde a solução ótima do problema conjunto pode não coincidir com as soluções ótimas de cada subproblema individualmente. Esta otimização pode ser determinística ou estocástica. A otimização determinística produz uma única solução para cada entrada e parâmetros, enquanto a otimização estocástica tem como objetivo explorar alternativas no espaço de soluções.

\section{Otimização determinística}

Sankoff propôs um algoritmo de programação dinâmica para otimizar o alinhamento e a predição da estrutura consenso utilizando um sistema de escore composto por parâmetros termodinâmicos e escores de alinhamento [234]. Porém, as complexidades de tempo de $O\left(n^{3 m}\right)$ e de memória de $O\left(n^{2 m}\right)$ (onde $n$ é o tamanho de uma seqüência típica e $m$ é o número de seqüências) limitam a aplicação para apenas duas seqüências curtas. Desde então, muitas variantes do algoritmo de Sankoff têm sido desenvolvidas adicionando heurísticas ou simplificações para tornar o algoritmo original mais eficiente. Exemplos são Dynalign [176, 174], PMComp e PMMulti [115], Stemloc [118], Consan [70], FoldAlign [96] e SLASH [97].

Dynalign $[176,174]$ simplifica o algoritmo de Sankoff impondo um tamanho de janela $w$ que

\footnotetext{
${ }^{17}$ Apesar do algoritmo de procura de cliques ser exponencial no número de seqüências de entrada, sua implementação em comRNA tem um tempo de processamento médio aceitável, permitindo a análise de 18 seqüências com até 300nt cada [129]
} 
limita a distância máxima entre duas bases alinhadas. Isto reduz a complexidade de tempo e memória, respectivamente, para $O\left(n^{3} w^{3}\right)$ e $O\left(n^{2} w^{2}\right)$ para duas seqüências. O sistema de escore é puramente estrutural, o que torna o Dynalign atrativo para aplicação em seqüências divergentes.

PMMulti [115] realiza um alinhamento estrutural múltiplo de um conjunto de seqüências utilizando um programa do mesmo pacote, PMComp, para realizar alinhamentos pairwise ${ }^{18}$. PMComp utiliza a mesma estratégia de limitação de distância de Dynalign para computar alinhamentos estruturais pairwise. Porém, ao invés de implementar regras puramente termodinâmicas, PMComp utiliza a informação das matrizes termodinâmicas de probabilidades de pareamentos, computadas para cada seqüência de entrada, para calcular um escore de probabilidade. Esse escore, atribuído para os pares de bases $(i, j)$ na seqüência $A$ e $(k, \ell)$ na seqüência $B$, refletem a probabilidade conjunta das posições $(i, j)$ e $(k, \ell)$ estarem pareadas. Mais especificamente, dadas duas matrizes de probabilidades $P_{A}$ e $P_{B}$ para as seqüências $A$ e $B$, respectivamente, o escore de probabilidade é calculado como $\log \left(P_{A}(i, j) / p_{\min }\right)+\log \left(P_{B}(k, \ell) / p_{\min }\right)$, onde $p_{\text {min }}$ é a probabilidade mínima de pareamento considerada significativa. PMComp combina mais dois tipos de escores: de substituição de bases e de covariação. Esta estratégia, junto com a restrição de distância de alinhamento, permite que PMComp execute em tempo $O\left(n^{4}\right)$ e com memória $O\left(n^{3}\right)$.

Dois métodos, Stemloc [118] e Consan [70], utilizam Gramáticas Livres de Contexto Estocásticas de Pares (GLCEPs) como modelos probabilísticos e impõem restrições no algoritmo de análise sintática para obter ganhos em eficiência. Stemloc fornece um esquema flexível para impor restrições definidas pelo usuário sobre o alinhamento, sobre a estrutura de uma seqüência e/ou sobre a estrutura consenso. O programa utiliza analisadores sintáticos adaptados para restringir a análise sintática a envelopes definidos pelas restrições, reduzindo a utilização de tempo e memória [119]. Consan [70] utiliza pins, um tipo específico de âncora de alinhamentos. Um pin é um par de posições de duas seqüências de entrada que tem uma alta probabilidade de estarem alinhadas. Dois pins consecutivos definem fronteiras onde o alinhamento e a predição estrutural são realizados. Os pins são selecionados de um alinhamento pairwise não estrutural e probabilístico, obtido utilizando um Modelo Oculto de Markov de Pares. Mesmo poucos pins podem diminuir o tempo e a memória exigidos significativamente, alcançando máximo desempenho quando são uniformemente espaçados. Dependendo das restrições, Stemloc pode alcançar tempo e memória $O\left(n^{2}\right)$, e Consan pode alcançar tempo $O\left(n^{3}\right)$ e memória $O\left(n^{2}\right)$ para duas seqüências.

FOLDALIGN [107] realiza alinhamento local ao invés de global, tornando-o capaz de detectar motivos em comum nas seqüências de entrada. O algoritmo utiliza uma janela deslizante em cada seqüência para limitar a busca por motivos. As janelas têm um tamanho limitado parametrizado

\footnotetext{
${ }^{18} \mathrm{Na}$ verdade, por motivos de eficiência, a primeira fase de cálculos, onde as seqüências são alinhadas duas de cada vez, PMMulti utiliza um alinhamento mais grosseiro de probabilidades utilizando um algoritmo descrito em [19].
} 
pelo tamanho máximo de um motivo, $\lambda$. O ganho de eficiência é alcançado limitando a diferença de tamanho de duas subseqüências utilizando um segundo parâmetro, $\delta$. A complexidade de tempo total é $O\left(n^{2} \lambda^{2} \delta^{2}+N \lambda^{4} \delta^{2}\right)$, onde $N$ é o número máximo de alinhamentos estruturais locais a serem extraídos das seqüências.

O sistema SLASH (Stem-Loop Align SearcH) [97] combina FOLDALIGN [96] e COVE ${ }^{19}$ [80]. FOLDALIGN é aplicado em um pequeno subconjunto das seqüências de entrada, produzindo um conjunto de alinhamentos estruturais locais pairwise. Estes são combinados para formar um conjunto de alinhamentos múltiplos, cada um descrevendo um motivo local. SLASH então utiliza COVE para procurar ocorrências de cada um desses motivos nas seqüências restantes. SLASH detecta somente estruturas stem-loop, não estruturas ramificadas, devido à utilização de uma versão antiga do FOLDALIGN.

\section{Otimização estocástica}

RAGA [193] e COFOLGA [260] utilizam algoritmos genéticos para produzir alinhamentos estruturais globais de pares de seqüências. Em ambos, a população de indivíduos consiste de alinhamentos pairwise das seqüências de entrada. Operadores de mutação alteram os alinhamentos realizando mudanças localizadas tais como inserção e deslocamento de gaps. Operadores de crossover geram descendentes que mantêm blocos de alinhamento que sejam comuns aos alinhamentos parentais com uma combinação dos blocos de alinhamento restantes.

RAGA (RNA Alignment by Genetic Algorithm) [193] e sua versão paralela PRAGA (Parallel RAGA) requerem a estrutura de uma das seqüências como entrada, que pode conter pseudo-nós. A compatibilidade com essa estrutura é utilizada para avaliar a população de alinhamentos.

COFOLGA (COmmon FOLding by Genetic Algorithm) [260], não requer qualquer informação estrutural. Ao invés disso, ele implementa uma variação do algoritmo de simulated annealing descrito por Schmitz [240] para predizer a estrutura de um par de seqüências alinhadas. Nesta variação, hélices que não sejam compatíveis com o alinhamento de seqüências são descartadas (isto é, hélices que ocorrem somente em uma das sequiências). O escore do alinhamento e o valor de energia livre de cada estrutura são combinados para obter o escore individual utilizado no processo de seleção dos indivíduos. Além da estrutura consenso, um passo de pós-processamento também prediz estruturas específicas para cada seqüência.

\subsection{Comparação estrutural}

A comparação estrutural calcula quão diferente duas estruturas são. Nós podemos medir essa diferença computando uma distância de edição entre duas estruturas. A distância de edição depende

\footnotetext{
${ }^{19}$ Veja seção 2.5 .
} 
de quantas operações são necessárias para transformar uma das estruturas na outra e no custo de cada tipo de operação de edição. A computação da distância de edição é diretamente relacionada com a forma na qual as estruturas são representadas e em que nível de resolução a comparação é feita. Três formas comuns de representar estruturas secundárias de RNA são árvores, seqüências de parênteses e grafos. Os níveis de resolução variam de pares de bases a padrões estruturais como hélices, loops e multi-loops.

\subsubsection{Utilização de árvores e seqüências de parênteses}

Ao utilizar árvores para representar estruturas, as operações de edição utilizadas para computar a distância são inserção e remoção de nós. Alguns métodos rotulam os nós das árvores com informação numérica, afetando o peso de cada operação realizada nesses nós.

RNAdistance [117] define três resoluções: total, baixa granularidade e baixa granularidade com pesos. A resolução total utiliza duas representações: seqüências de parênteses e árvores. As resoluções de baixa granularidade e de baixa granularidade com pesos utilizam árvores. Em uma seqüência de parênteses, parênteses casados (abre e fecha parênteses) indicam bases pareadas, enquanto pontos indicam bases não pareadas [117]. A distância entre duas estruturas nesta representação é computada como o número de gaps necessários para produzir um alinhamento de suas seqüências de símbolos. As árvores utilizadas para representar resolução total, homeomorphically irreducible trees (HITs), são compostas de dois tipos de nós, P para pares de bases e U para bases não pareadas. Cada nó é rotulado pelo número de consecutivos pares de bases ou bases não pareadas, respectivamente. Por exemplo, uma hélice que possui 3 pares de bases consecutivos é representada pelo nó P3. Já as árvores utilizadas para representar resoluções de baixa granularidade e baixa granularidade com pesos têm cinco tipos de nós [247]: "stem", "hairpin", "bojo", "loop interno" e "multi-loop". A diferença nestas duas resoluções é que, na baixa granularidade com pesos, os nós são rotulados com seus tamanhos (pares de bases para hélices e bases únicas para as demais).

MiGal [4] utiliza árvores com apenas dois tipos de nós: "hélice" e "loop". Por outro lado duas novas operações são utilizadas: "fusão de arestas" e "fusão de nós". Estas novas operações permitem, por exemplo, associar uma hélice longa a duas hélices menores separadas por um loop interno ou um bojo, ao invés de realizar uma associação um-para-um (uma hélice para apenas uma das hélices menores) exigida pelas operações tradicionais de edição de árvores descritas acima.

\subsubsection{Utilização de grafos}

Uma estrutura secundária pode também ser representada por um grafo genérico (ao invés de uma árvore). Isto permite a aplicação de técnicas da teoria dos grafos para executar comparação 
topológica de grafos. Um possível mapeamento é modelar loops como nós e hélices como arestas. O segundo menor auto-valor da matriz Laplaciana de um grafo é uma medida de sua conectividade, que indica o padrão de bifurcamento da estrutura secundária [11]. Este valor, acompanhado do número de nós, pode ser utilizado para agrupar estruturas similares.

RNAMute [43] utiliza métricas de grafos e edição de árvores para predizer mudanças estruturais causadas por mutações pontuais.

O mesmo princípio de modelagem por grafos é utilizado para caracterizar e buscar estruturas de RNAs no banco de dados RAG (RNA-As-Graph) [92]. Este banco de dados é um catálogo de estruturas secundárias, reais e hipotéticas, em um formato de grafo, acumulando informações sobre características topológicas (incluindo pseudo-nós) e famílias de RNAs apresentando estruturas específicas. Dada a estrutura secundária de um RNA de interesse, RAG fornece RNAs estruturalmente isomórficos de sua base de dados.

\subsubsection{Utilização de todo o espaço de estruturas}

RNApdist [117] compara todo o espaço de estruturas de duas seqüências para computar um valor de distância. A computação desta distância considera o tamanho médio das duas seqüências e o escore de similaridade $S$ do alinhamento de seus espaços de estruturas. O espaço de estruturas de cada seqüência é representado por três vetores, $p^{<}, p^{>}$e $p^{o}$, onde $p_{i}^{<}, p_{i}^{>}$e $p_{i}^{o}$ são a probabilidade da posição $i$ de uma seqüência estar, respectivamente, pareada com uma outra base à direita, pareada com outra base à esquerda, e não pareada. Estes valores são calculados utilizando a matriz termodinâmica de probabilidades de pareamentos das seqüências:

$$
p_{i}^{<}=\sum_{j>i} p_{i j} \quad p_{i}^{>}=\sum_{j<i} p_{i j} \quad p_{i}^{o}=1-p_{i}^{<}-p_{i}^{>}
$$

Dadas duas posições $i$ e $k$ das seqüências $A$ e $B$, respectivamente, o escore $\gamma(i, k)$ de alinhar estas duas posições é definido por

$$
\gamma(i, k)=\sqrt{p_{i}^{<}(A) p_{k}^{<}(B)}+\sqrt{p_{i}^{>}(A) p_{k}^{>}(B)}+\sqrt{p_{i}^{o}(A) p_{k}^{o}(B)} .
$$

O escore de um alinhamento qualquer entre os espaços de $A$ e $B$ é

$$
\hat{\gamma}(\vec{i}, \vec{k})=\sum_{i \quad \text { alinhada }}{ }_{\text {com }} \gamma(i, k)
$$

e o escore de um alinhamento ótimo é

$$
S(A, B)=\max _{(\vec{i}, \vec{k})} \hat{\gamma}(\vec{i}, \vec{k})
$$


onde $(\vec{i}, \vec{k})$ é um par de vetores de posições das seqüências $A$ e $B$, respectivamente.

Finalmente, a distância $\delta(A, B)$ entre duas seqüências $A$ e $B$ é definida por:

$$
\delta(A, B)=\frac{|A|+|B|}{2}-S(A, B)
$$

onde $|A|$ e $|B|$ são o tamanho das seqüências $A$ e $B$, respectivamente.

\subsection{Identificação de RNAs não codificantes}

Com o crescimento exponencial de dados de seqüenciamento sendo gerados, a tarefa de varrer um novo genoma para encontrar candidatos a genes de ncRNAs tem se tornado cada vez mais importante. A detecção computacional de ncRNAs em geral é um desafio, e é considerado um problema em aberto. As abordagens mais utilizadas são o desenvolvimento de programas de identificação orientados para famílias específicas de ncRNAs (utilizando tanto quanto possível as peculiaridades destas famílias) e a criação de programas mais gerais que podem ser treinados para identificar características de uma família específica ou mesmo de uma única seqüência de entrada. Porém, o desenvolvimento de detectores gerais de ncRNAs é ainda um importante desafio, uma vez que acredita-se que muitas famílias de ncRNAs ainda não foram descobertas [74].

Detectores de genes podem ser implementados como varredores de genomas ou como classificadores. A varredura genômica é freqüentemente executada através do deslizamento de uma janela e análise de sua seqüência. Os classificadores emitem um rótulo para uma entrada recebida. Esta entrada pode ser uma seqüência no caso de um detector de gene ab initio ou um alinhamento no caso de um detector de gene comparativo. No primeiro caso, as seqüências de entrada podem ser obtidas utilizando uma janela deslizante sobre um genoma ou podem ser seqüências de transcritos.

\subsubsection{Detectores gerais de genes de ncRNAs}

\section{Métodos $a b$ initio}

\section{Utilização de informação termodinâmica apenas}

Le et al. propuseram que seqüências de RNAs têm um valor de energia livre mínima inferior aos de seqüências aleatórias com a mesma composição de bases [153]. Esta característica poderia ser utilizada para detectar ncRNAs utilizando uma janela deslizante sobre um genoma e comparando sua ELM com a ELM de embaralhamentos desta mesma seqüência. O programa NCRNASCAN [219] foi implementado para testar esta estratégia. Porém, os autores mostraram que, apesar do fato que 
muitos ncRNAs apresentam essa diferença energética, esta diferença não é significativa o bastante para ser utilizada em um discriminador de ncRNAs em geral.

Considerando o fato de que o cálculo da ELM de uma molécula é baseada em empilhamentos de bases, Workman e Krogh [289] propuseram que a ELM da seqüência original deveria ser comparada com embaralhamentos que preservem a freqüência de dinucleotídeos, e não apenas a de mononucleotídeos. O programa RANDFOLD [20] foi implementado baseado neste argumento. Ele foi utilizado para mostrar que, apesar de que alguns ncRNAs não têm uma energia significativamente mais baixa que seqüências aleatórias, isso é verdade para precursores de microRNAs [20]. Um trabalho posterior [46] mostrou que outros ncRNAs também podem ser detectados utilizando essa estratégia.

A inclusão ou remoção de bases de uma seqüência afeta seu valor de ELM. Isto tem um impacto importante quando um genoma é varrido por uma janela deslizante, uma vez que não é garantido que o tamanho da janela coincida exatamente com o dos ncRNAs que estão sendo procurados. O problema da falta de nucleotídeos pode ser solucionado utilizando uma janela grande o bastante para acomodar qualquer ncRNA, mas o efeito de nucleotídeos extras permanece. Como conseqüência, um único dobramento de cada janela poderá produzir um valor de energia irreal. Para diminuir esse problema, RNAplfold [13] combina a informação obtida de todas as janelas individuais de um genoma. Dada uma janela de tamanho $L$, as estruturas estáveis de um genoma são detectadas computando, para todas as posições $i$ e $j$, a probabilidade média das bases nas posições $i$ e $j$ estarem pareadas. Esta probabilidade é calculada considerando todas as possíveis estruturas em todas as janelas de tamanho $L$ tendo as bases $i$ e $j$.

\section{Utilização de informação composicional}

RNAs não codificantes em geral possuem um conteúdo GC médio de $50 \%[219]^{20}$. Este fato inspirou buscas por ncRNAs utilizando estatísticas composicionais. A estratégia de busca por ilhas ricas em GC identificou vários ncRNAs em alguns organismos com genoma rico em AT [139]. Uma estratégia similar utilizando outras estatísticas de mono e dinonucleotídeos foi também executada em outros organismos, sendo a estatística de GC a que obteve melhores resultados [235].

\section{Utilização de técnicas de aprendizado computacional}

Abordagens de aprendizado computacional são uma opção interessante no desenvolvimento de detectores de genes adaptáveis. Uma vez que um modelo é desenhado, ele pode ser treinado para

\footnotetext{
${ }^{20}$ Conteúdo GC é a porcentagem de bases G e C.
} 
reconhecer uma família específica de genes a partir de amostras de genes já conhecidos. CONC [161] é um programa desenvolvido para analisar seqüências utilizando a tecnologia de Support Vector Machine (SVM). Ele foi implementado para classificar uma seqüência como sendo codificante de proteína ou de RNA não codificante. Este programa utiliza um conjunto de características para modelar seqüências codificantes de proteínas, tais como composição de aminoácidos, tamanho do peptídeo e outras características mais específicas. A amostra de treinamento positiva é um conjunto de seqüências codificantes enquanto a amostra negativa é um conjunto de RNAs não codificantes.

\section{Métodos comparativos}

Dadas duas ou mais espécies relacionadas, é possível obter alinhamentos de seus genomas para encontrar regiões de máxima similaridade entre eles. No caso de vários genomas, estes alinhamentos podem ser construídos comparando dois genomas de cada vez e então construindo um alinhamento múltiplo extraindo regiões alinhadas comuns a todos os genomas. Uma vez que se tem um alinhamento múltiplo, tanto a informação termodinâmica quanto a análise de covariação podem fornecer evidências para uma rotulação de ncRNA. No entanto, a qualidade desses alinhamentos pode influenciar o desempenho das ferramentas utilizadas para classificá-los.

O programa ddbRNA [61] computa o número de mutações compensatórias em um alinhamento múltiplo e seu Z-escore utilizando embaralhamentos desse alinhamento. Apesar de rápido $\left(O\left(n^{2}\right)\right)$, este programa tem uma baixa confiabilidade (sensitividade média de $\sim 22 \%$ para alinhamentos pairwise obtidos por BLAST), e portanto não tem sido utilizado em aplicações da vida real [281].

MSARI [53] diminui a dependência da qualidade do alinhamento inicial permitindo erros de alinhamento com até dois caracteres de distância. Além disso, a significância das covariações é calculada considerando a possibilidade de que substituições aleatórias de nucleotídeos possam causar covariações. No entanto, para alcançar uma maior precisão, MSARI necessita de um alinhamento contendo 10-15 seqüências.

QRNA [220] utiliza três modelos probabilísticos diferentes para classificar alinhamentos pairwise: um modelo de gramática livre de contexto estocástica de pares para ncRNAs, um modelo oculto de Markov de pares para RNAs codificantes e um modelo oculto de Markov de pares posição-independente para as "outras" seqüências ${ }^{21}$. Originalmente, QRNA tinha baixa confiabilidade para alinhamentos fora de um intervalo ótimo de identidade de 65-85\% [281], porém uma nova versão, eQRNA[217], inclui a distância evolutiva entre as seqüências nos parâmetros do modelo, atingindo melhores resultados.

RNAZ [281], desenvolvido a partir de RNAalifoldz[280], é um classificador baseado em Support

\footnotetext{
${ }^{21}$ Pode-se dizer que "outras" significa "Não sei classificar".
} 
Vector Machine que utiliza dois escores para classificar alinhamentos múltiplos como de ncRNAs ou não: Z-escores ${ }^{22}$ termodinâmicos das seqüências individuais do alinhamento de entrada e um índice de conservação de estrutura (ICE). O último é dado por $E_{A} / \bar{E}$, onde $E_{A}$ é um escore termodinâmico do alinhamento $A$ (escore calculado pelo programa RNAalifold), e $\bar{E}$ é a energia livre média das seqüências individuais (cada energia calculada pelo RNAfold). A idéia é que, quanto maior a conservação de estrutura e as covariações, maior será o ICE.

Como mencionado acima, todos os métodos comparativos descritos dependem da precisão do alinhamento. Mesmo MSARI somente fornece bons resultados para alinhamentos que possuem identidade superior a 50\%. Um trabalho recente de Uzilnov et al. [272] propõe um método que não requer um alinhamento inicial. Este método utiliza o Dynalign, uma ferramenta para predição de estrutura secundária consenso ${ }^{23}$. Dynalign alinha e dobra simultaneamente duas seqüências considerando apenas informações termodinâmicas. Uma vez que o programa fornece a energia livre do alinhamento, ele foi utilizado para calcular o Z-escore termodinâmico do alinhamento ${ }^{24}$. Em testes envolvendo sequiências de baixa identidade (menos de 50\%), Dynalign obteve melhores resultados que os obtidos por RNAZ, tanto em sensitividade quanto em especificidade.

\subsubsection{Detectores de genes de ncRNAs baseados em um conjunto de seqüências conhecidas}

Estes detectores de genes atacam o problema de, dado um conjunto de genes de uma mesma família de RNAs, analisar outras seqüências e classificá-las como pertencentes a essa família ou não.

Gramáticas livres de contexto estocásticas foram originalmente utilizadas para caracterizar famílias de RNAs e buscar seqüências homólogas nos trabalhos independentes e simultâneos de Sakakibara et al. [230] e Eddy e Durbin [80].

Sakakibara e seus colaboradores desenharam manualmente gramáticas para tRNAs (transfer RNAs) [228] e snoRNAs (small nucleolar RNAs) [271]. Cada gramática foi utilizada para analisar seqüências, computando um valor de probabilidade. A classificação das seqüências era então feita baseada no cálculo do Z-escore dessa probabilidade (detalhes em [144]).

Eddy e Durbin desenvolveram o pacote INFERNAL [80] (inicialmente chamado COVE) utilizando um tipo equivalente de GLCEs chamado Modelos de Covariância [71]. INFERNAL inclui programas

\footnotetext{
${ }^{22}$ A computação de Z-escore necessita da média e desvio padrão dos escores de seqüências negativas. Freqüentemente, estas medidas são calculadas utilizando embaralhamentos da seqüência de entrada. Ao invés disso, RNAZ pré-computa estes valores para tamanhos e composições de bases específicos de seqüências utilizando uma regressão de Support Vector Machine. Isso acelera o tempo de execução do RNAZ.

${ }^{23}$ Veja a seção 2.3.2.

${ }^{24}$ Outra opção explorada neste trabalho foi a utilização da energia do alinhamento como uma característica de um classificador baseado em Support Vector Machine (mais rápido porém um pouco menos sensível).
} 
para inferir automaticamente uma gramática a partir de um alinhamento múltiplo estrutural (que irá caracterizar uma família de ncRNAs) e varrer um genoma utilizando tal gramática, procurando seqüências homólogas candidatas. Uma importante característica do INFERNAL é a utilização de um algoritmo de busca que faz uma utilização mais eficiente da memória que outros algoritmos baseados em GLCEs $\left(O\left(n^{2} \log n\right)\right.$ contra $\left.O\left(n^{3}\right)\right)$ [76], o que permite a busca de longos ncRNAs como os ribossomais.

Rfam [100, 101] é um sistema de banco de dados que armazena modelos de covariância para 503 diferentes famílias de ncRNAs (versão 7.0) e que utiliza INFERNAL para identificar candidatos a ncRNAs em uma seqüência de entrada arbitrária (possivelmente um genoma inteiro). Como a análise da seqüência de entrada utilizando todos os 503 modelos seria muito lenta, um filtro baseado em BLAST é inicialmente aplicado para selecionar modelos promissores. Este filtro de similaridade impõe restrições no grau de variação que é aceitável para encontrar ncRNAs. Weinberg et.al. [285, 286] propuseram um filtro diferente, baseado em perfis de HMMs, a fim de melhorar a sensitividade dos filtros baseados em BLAST. Estes filtros, porém, não são parte do banco de dados Rfam.

Analisar uma seqüência, mesmo utilizando uma única GLCE, pode ser lento. A complexidade de tempo de $O\left(n^{4}\right)$ significa um longo tempo de espera para a análise de seqüências longas. Para acelerar esse processo, restrições na análise sintática foram implementadas no pacote RNACAD [25], baseado em GLCEs, um software utilizado no Ribosomal Database Project (RDP-II) [48]. Cada restrição limita as subseqüências que podem ser reconhecidas por um dado não-terminal ${ }^{25}$. Estas restrições são geradas automaticamente, construindo um HMM que aproxima a GLCE, e identificando subseqüências associadas com um estado do HMM com alta probabilidade. Estas associações constituem as restrições da GLCE.

Gramáticas livres de contexto não são capazes de modelar dependências cruzadas, e portanto são incapazes de modelar pseudo-nós [246]. No entanto, um pseudo-nó pode ser modelado caracterizando cada uma das hélices separadamente. Este modelo, baseado em intersecções de GLCEs, foi descrito por Brown e Wilson [26]. Neste trabalho eles descrevem como estimar as probabilidades da combinação de gramáticas e também como analisar sintaticamente as seqüências mantendo as complexidades de tempo e memória de $O\left(n^{3}\right)$ e $O\left(n^{2}\right)$, respectivamente.

PSoL (Positive Sample only Learning) [277] propõe uma maneira flexível de parametrizar um processo de classificação. Ele recebe como entrada vetores de características de sequiências de treinamento (da família de RNAs a ser caracterizada) e das sequiências a serem analisadas, e então seleciona um conjunto de características que sejam significativas para serem utilizadas no processo

\footnotetext{
${ }^{25}$ Símbolos não-terminais são símbolos auxiliares utilizados para estruturar regras gramaticais.
} 
de classificação. PSoL utiliza tecnologia de SVM e, portanto, necessita de amostras de treinamento positiva e negativa. Enquanto a amostra de treinamento positiva é um conjunto de ncRNAs de interesse, uma definição apropriada de uma amostra negativa não é trivial. Para isso PSoL implementa uma estratégia de selecionar esta amostra negativa diretamente da amostra ainda não classificada (seqüências a serem analisadas). Um conjunto inicial de seqüências negativas são selecionadas de forma a maximizar a distância entre a amostra positiva e a atual amostra negativa assim como a distância mútua entre as seqüências negativas ${ }^{26}$. Após um treinamento inicial utilizando esta amostra negativa, a classificação é iniciada. À medida que novas seqüências vão sendo classificadas como não-ncRNAs, elas são incorporadas à amostra negativa, e o classificador é re-treinado. PSoL foi desenvolvido para executar uma busca por qualquer ncRNA em um banco de dados, utilizando como amostra de treinamento um conjunto de seqüências pertencentes a várias famílias distintas de ncRNAs. Porém, esta abordagem é claramente flexível o suficiente para ser também aplicada a famílias específicas de genes.

RSEARCH [138] e FastR [8], ao invés de executar um treinamento estatístico prévio utilizando várias seqüências, aceitam como entrada uma seqüência de RNA e sua estrutura secundária, e então varrem um banco de dados à procura de seqüências similares à seqüência de entrada executando um alinhamento estrutural. Para construir esse alinhamento, eles utilizam RIBOSUMs, matrizes de substituição específicas para RNAs, desenvolvidas no trabalho do RSEARCH. Os dois métodos, além do escore do alinhamento, fornecem a significância do escore. A varredura de um genoma, porém, pode ser uma tarefa demorada. Para uma seqüência de tamanho $n$ e um banco de dados (ou genoma) de tamanho $m$, a complexidade de tempo de pior caso para esta varredura é $O\left(m n^{3}\right)$, mais um adicional de $O\left(n^{4}\right)$ para cálculos de significância estatística. RSEARCH tenta contornar essa dificuldade oferecendo, opcionalmente, uma versão de implementação paralela. FastR, ao contrário, utiliza filtros estruturais para pré-selecionar seqüências promissoras.

\subsubsection{Detectores de genes de famílias específicas de ncRNAs}

A fim de alcançar maior sensitividade e especificidade, alguns métodos são customizados para lidar com famílias específicas de RNAs, explorando características específicas de cada uma. Esses métodos exemplificam como o conhecimento a priori sobre uma família de RNAs pode ser utilizada para construir um detector família-específico de genes de ncRNAs.

RNAs transportadores (tRNAs) são seqüências com tamanho entre 74 e 90 bases, transcritos pela RNA polimerase III, que dobram-se em uma estrutura de trevo de quatro-folhas.

\footnotetext{
${ }^{26} \mathrm{~A}$ última condição tem como objetivo minimizar a redundância e aumentar a cobertura da amostra negativa.
} 
O programa tRNAscan-SE [162] é considerado um dos preditores de tRNAs mais precisos [151]. Ele combina três programas: dois preditores de tRNAs que buscam promotores de RNA polimerase III e características da estrutura secundária [84, 199], e um Modelo de Covariância [80] treinado com seqüências de tRNAs. Os dois primeiros programas são rápidos e, quando combinados, possuem uma sensitividade superior a aproximadamente 99\%. Porém, tal combinação implica em uma taxa de aproximadamente 1.85 falsos positivos por $\mathrm{Mb}$, o que é aceitável para genomas pequenos, mas significa aproximadamente 5500 falsos positivos no genoma humano. O Modelo de Covariância é bastante sensível e específico, mas muito lento. Portanto, os dois primeiros preditores de tRNAs são utilizados com baixa estringência como pré-filtros a fim de obter candidatos promissores de tRNAs de um genoma. Os candidatos são então analisados pelo modelo de covariância, altamente estringente. O resultado é um identificador de tRNAs apresentando alta sensitividade (99-100\%) e seletividade (com uma taxa de falsos positivos inferior a 0.00007 por $\mathrm{Mb}$ ) com uma velocidade razoável $(30 \mathrm{~Kb} / \mathrm{s})$.

RNAs transportadores-mensageiros (tmRNAs) são seqüências com tamanho entre 350 e 400 bases $^{27}$ que são capazes de liberar mRNAs defeituosos de ribossomos emperrados [104]. As extremidades 5' e 3' desta molécula formam um domínio que se assemelha a um tRNA, e que encerra uma região interna que consiste de stem-loops, pseudo-nós e um domínio de RNA mensageiro. Este último codifica para uma etiqueta peptídica que sinaliza o mRNA defeituoso para degradação [152]. ARAGORN [151], uma evolução do programa BRUCE [152], é um programa que identifica tmRNAs selecionando candidatos que possuem padrões específicos de seqüências de tRNAs envolvendo as extremidades 5' e 3' e inspecionando a estrutura secundária predita. Finalmente, ARAGORN também analisa as regiões ao redor do domínio codificante para identificar se elas poderiam se dobrar em certos motivos estruturais específicos. ARAGORN também pode detectar tRNAs com uma sensitividade comparável à do tRNAscan-SE, mas sem a mesma especificidade.

Small nucleolar RNAs (snoRNAs) são seqüências com tamanho entre 60 e 300 bases que estão relacionadas com modificações sítio-específicas de outros RNAs [177]. Eles estão divididos em snoRNAs guias e órfãos, dependendo da presença ou ausência de um RNA alvo conhecido. Dependendo de sua estrutura secundária, eles podem ser classificados em $C / D$ box e $H / A C A$ box. A estrutura secundária de snoRNAs C/D box é basicamente uma estrutura hairpin-like, onde algumas regiões localizadas no loop (boxes $\mathrm{C}$ e D) têm uma seqüência conservada. Este loop também possui regiões que são complementares ao RNA alvo. A estrutura secundária de snoRNAs H/ACA box consiste de duas hélices consecutivas, cada uma seguida por uma região conservada de loop (H box após a

\footnotetext{
${ }^{27} \mathrm{O}$ tmRNA de C. merolae é excepcionalmente menor, possuindo apenas 235 bases [59].
} 
primeira hélice e ACA box após a segunda hélice). Cada hélice tem também um loop interno cujas seqüências são complementares ao RNA alvo.

O programa snoscan [163] é um detector de snoRNAs C/D box guias que utiliza uma GLCE para modelar o hairpin, um HMM para cada região conservada e um modelo de distribuição de tamanho para caracterizar as distâncias entre as regiões conservadas. O modelo combinado é então utilizado para atribuir escores a candidatos a snoRNAs. Este programa pode detectar apenas snoRNAs guias pelo fato de que um dos HMMs modela a região de binding a alvos conhecidos. A combinação de diferentes modelos para regiões distintas é também empregada pelo snoGPS [237] para identificar snoRNAs H/ACA box guias. Weight matrices são utilizadas para modelar diversas regiões de seqüência primária (boxes, loops internos e laterais de hélices em separado) e modelos de distribuição de tamanho são utilizados para conectá-los. O pacote snoSeeker [292] é capaz de detectar snoRNAs tanto guias quanto órfãos. Este pacote consiste de dois programas: CDseeker e ACAseeker. Ambos buscam inicialmente todas as regiões conservadas (boxes) e então buscam evidências estruturais (hélices) correspondentes ao tipo de snoRNA de interesse. O último passo é a busca por alvos que possuem regiões de similaridade com a região de binding ao RNA alvo ${ }^{28}$. Se o alvo é encontrado, o candidato é classificado como guia, senão é classificado como órfão.

Micro RNAs (miRNAs) são inicialmente transcritos como seqüências entre 60 e 90 bases que dobram-se em uma estrutura de stem-loop (pre-miRNA). Esta seqüência é processada, originando duas moléculas de aproximadamente 21 bases, cada uma vindo de um lado da hélice. A seqüência originada do lado 5' irá se anelar ao mRNA alvo, impedindo sua tradução ${ }^{29}$. Esta seqüência processada é bem conservada entre espécies, sendo a porção inicial a mais conservada.

Preditores de micro RNAs, além de buscarem características comuns destes RNAs, também buscam conservação evolutiva. Por exemplo, miRseeker [149] e mirScan [156] utilizam a seqüência de dois genomas de diferentes espécies para identificar candidatos a miRNAs conservados em ambos. Estes genomas são varridos à procura de potenciais estruturas stem-loop que, se conservadas, são selecionadas como pré-candidatas para análise posterior. Os programas miralign [279] e ProMirII [190] utilizam um conjunto de miRNAs conhecidos e os comparam com os candidatos a miRNAs de um genoma de entrada. Finalmente, RNAmicro [110] não varre um genoma, mas classifica alinhamentos múltiplos.

\footnotetext{
${ }^{28}$ Supõem-se que os RNAs alvos são rRNAs ou snRNAs.

${ }^{29} \mathrm{Em}$ alguns miRNAs as duas seqüências, originadas dos lados 5' e 3', podem ser utilizadas em diferentes mRNAs alvos.
} 
CAPÍtulo 3

\section{Busca de ncRNAs em Plasmodium falciparum}

Tomando o Plasmodium falciparum como organismo modelo neste estudo de predição de ncRNAs, uma parte do trabalho desta tese foi dedicada ao problema de busca de ncRNAs em geral. Como discutido na seção 1.1, além do desafio de bioinformática de identificar novos ncRNAs neste organismo, há a motivação biológica de que, uma vez que ncRNAs desempenham importantes funções celulares, essas descobertas podem ajudar a esclarecer a biologia de P. falciparum, auxiliando no desenvolvimento de novas alternativas de tratamento da malária que ele ocasiona.

Dentre os métodos ab initio de identificação de ncRNAs em geral descritos no capítulo 2, a busca por regiões ricas em GC, e portanto potenciais ncRNAs com estruturas secundárias termodinamicamente estáveis, parecia promissora em $P$. falciparum uma vez que tais regiões seriam facilmente detectáveis em meio ao alto conteúdo AT de seu genoma. No entanto, essa técnica não se aplica muito bem a este organismo, uma vez que mesmo seus ncRNAs possuem um alto conteúdo AT, se confundindo com as regiões intergênicas [235]. Esse alto conteúdo AT dos ncRNAs deve ser um dos motivos para haver poucos ncRNAs conhecidos neste organismo. Sendo tão ricos em AT apresentam, conseqüentemente, maior divergência em relação aos ncRNAs conhecidos em outros organismos, uma vez que estes últimos apresentam em média 50\% de GC [219]. A divergência não é apenas em seqüência mas também em tamanho, como exemplificado na seção 1.2.

Análise comparativa é uma abordagem freqüentemente utilizada para detectar genes conservados em duas ou mais espécies, principalmente quando um novo genoma é seqüenciado. Mesmo com a disponibilidade de genomas de outras espécies de Plasmodium, poucos ncRNAs são conhecidos em $P$. falciparum. Uma espécie próxima filogeneticamente de $P$. falciparum com genoma já publicado é $P$. yoelii [29]. Esta espécie causa malária em roedores, e também possui um alto conteúdo AT ( $P$. yoelii possui $77.4 \%$ AT, enquanto $P$. falciparum possui $81.6 \%$ AT), sendo assim um bom candidato 
para a realização de um estudo de análise comparativa para predizer novos ncRNAs conservados em $P$. falciparum e $P$. yoelii.

Para realizar essa tarefa, selecionamos o programa eQRNA [217, 220], que adapta seus modelos conforme a divergência das seqüências sendo analisadas. O programa eQRNA analisa alinhamentos entre duas espécies distintas e classifica-os em três categorias: ncRNAs, proteínas ou outro (não classificado). Desta forma, o primeiro passo para a aplicação deste método é a obtenção de alinhamentos entre os genomas de $P$. falciparum e $P$. yoelii.

Alinhamentos são construídos baseados em um sistema de escore definido por uma matriz de similaridade e penalidades de abertura e extensão de gaps. Há uma teoria estatística desenvolvida para analisar a significância dos escores dos alinhamentos obtidos utilizando uma determinada matriz e penalidades de gaps [133]. Dentro dessa teoria, os valores de qualquer matriz de similaridade são interpretados em função de uma distribuição de fundo (isto é, a freqüência de nucleotídeos de um banco de dados ou dos genomas sendo comparados) e de uma porcentagem de identidade alvo para o alinhamento. Esta porcentagem alvo está relacionada com a divergência esperada entre as seqüências [79].

As matrizes de similaridade de nucleotídeos baseadas em apenas em dois parâmetros (escore de identidade e escore de substituição) permitem o ajuste da porcentagem de identidade alvo. No entanto, assumem uma distribuição de fundo uniforme, pois utilizam apenas 2 valores para as 16 possibilidades de alinhar 2 nucleotídeos. No entanto, como dito anteriormente, tanto $P$. falciparum quanto $P$. yoelii possuem uma freqüência genômica de nucleotídeos bem diferente da uniforme. Matrizes que não levam em consideração esse fato atribuem escores distorcidos para estes organismos, podendo levar tanto à construção de alinhamentos espúrios quanto à não detecção de regiões conservadas. Desta forma, a construção de uma matriz específica, assim como de penalidades de gaps ajustadas, pode obter alinhamentos mais precisos entre P. falciparum e P. yoelii ${ }^{1}$.

Neste trabalho, um script foi implementado para, dada uma porcentagem de identidade alvo e duas distribuições de fundo, calcular a matriz de escore apropriada. Esse script foi utilizado para calcular uma matriz $S$ utilizando as distribuições de fundo de $P$. falciparum e $P$. yoelii, e uma identidade alvo de $65 \%$. Esse valor foi baseado na identidade média dos RNAs RNaseP, RNase MRP e SRP entre P. falciparum e P. yoelii ${ }^{2}$.

Outra questão que independe da utilização de uma matriz de similaridade adequada, é que nem todos os alinhamentos obtidos são estatisticamente significativos. A significância do escore de

\footnotetext{
${ }^{1}$ Essa abordagem foi utilizada na busca de ncRNAs conservados em C. elegans, C. remanei e C. briggsae [256]. No entanto, não há neste trabalho uma descrição do cálculo dessa matriz e penalidades de gaps.

${ }^{2}$ A identidade média desses RNAs entre $P$. falciparum e $P$. yoelii foi de $68 \%$. No entanto utilizamos a identidade alvo de $65 \%$ pelo fato de ncRNAs serem freqüentemente divergentes em seqüência.
} 
um alinhamento pode ser avaliada através de uma medida chamada E-value . $^{3}$ O E-value de um alinhamento com escore $x$ é o número esperado de alinhamentos em um banco de dados de mesmo tamanho $n$, com mesma composição de bases (mas gerado de maneira aleatória) com escore maior ou igual a $x$ [143], ou seja,

$$
E=n P(X \geq x)
$$

Quando os alinhamentos são construídos sem permitir inserção de gaps, essa distribuição $P$ sobre X (variável aleatória para os escores obtidos), utilizada no cálculo do E-value, é a distribuição de Gumbel $^{4}$, também conhecida como distribuição do valor extremo [5]. Essa distribuição possui dois parâmetros, $\lambda$ e $K$. Os valores desses parâmetros dependem, dentre outros fatores ${ }^{5}$, da matriz utilizada para construir os alinhamentos $[133,134]$. Portanto, se a matriz de escore e as penalidades de gaps são alteradas, novos valores de $\lambda$ e $K$ precisam ser calculados para serem utilizados no cálculo de E-values.

Dados empíricos indicam que os escores de alinhamentos com gaps também seguem uma distribuição de Gumbel [5]. No entanto, para este caso não há ainda uma forma analítica para calcular seus parâmetros $\lambda$ e $K$, restando estimá-los através de simulações [72]. As ferramentas NCBIBLAST [192] e WU-BLAST [290] possuem uma tabela desses valores previamente estimados para um conjunto de matrizes e penalidades de gaps. No entanto, para matrizes e penalidades de gaps cujos parâmetros não foram previamente tabulados, os valores de $\lambda$ e $K$ devem ser estimados à parte e fornecidos na linha de comando, caso contrário os E-values fornecidos não serão confiáveis.

A seção 3.1 descreve todo o processo de obtenção de alinhamentos entre $P$. falciparum e $P$. yoelii através de uma matriz específica e o uso da ferramenta eQRNA na classificação dos alinhamentos. A seção 3.2 descreve os resultados obtidos.

\subsection{Métodos}

\subsubsection{Construção de alinhamentos entre $P$. falciparum e $P$. yoelii}

\section{Cálculo de uma matriz de similaridade e penalidades de gaps}

O processo descrito a seguir supõe que serão realizados alinhamentos entre seqüências de dois diferentes genomas, $G$ e $G^{\prime}$, com diferentes distribuições de fundo. Supõe-se também que as seqüên-

\footnotetext{
${ }^{3} \mathrm{O} P$-value é outra medida também utilizada para avaliar a significância de um escore, sendo esta a probabilidade de pelo menos um outro alinhamento apresentar escore maior ou igual a $x$. O $P$-value pode ser obtido do $E$-value: $P=1-e^{-E}[143]$.

${ }^{4}$ A função de distribuição cumulativa Gumbel é definida por $P(X<x)=\exp \left[-e^{-\lambda(x-\mu)}\right]$, onde $\mu=(\ln K m n) / \lambda$, $m$ é o tamanho da seqüência query e $n$ é o tamanho do banco de dados [5].

${ }^{5}$ Como o tamanho do banco de dados e da seqüência query, e suas composições de bases.
} 
cias do genoma $G$ serão sempre utilizadas como query enquanto o genoma $G^{\prime}$ será utilizado como banco de dados onde as buscas serão feitas.

Segundo a teoria desenvolvida para a análise de significância dos escores de alinhamentos [133, 134], uma matriz de similaridade de nucleotídeos é uma matriz $S_{4 \times 4}$ onde cada entrada $S_{i j}(i, j=$ 1, 2, 3, 4, representando os nucleotídeos A,C,G e T, respectivamente) é interpretada como:

$$
S_{i j}=\frac{1}{\lambda} \ln \frac{P(i, j)}{F(i) F^{\prime}(j)}
$$

onde $P(i, j)$ é a probabilidade do nucleotídeo $i$ de $G$ estar alinhado com o nucleotídeo $j$ de $G^{\prime}, F(i)$ e $F^{\prime}(j)$ são, respectivamente, as distribuições de fundo de $i$ no genoma $G$ e de $j$ no genoma $G^{\prime}$, e $\lambda$ é um fator de escala que pode ser utilizado para que os escores $S_{i j}$ assumam valores aproximadamente inteiros para posteriores arredondamentos ${ }^{6}[296]$.

Essa interpretação pode ser utilizada para calcular matrizes específicas para alinhamentos entre os genomas $G$ e $G^{\prime}$. Idealmente, $P(i, j)$ seria estimado a partir de um conjunto de alinhamentos corretos entre os genomas $G$ e $G^{\prime}$. No entanto, alinhamentos corretos exigem um sistema de escore preciso, que é justamente o que se deseja calcular. No entanto, $P(i, j)$ pode ser aproximado por ${ }^{7}$

$$
P(i, j)=P(i \mid j) F^{\prime}(j)
$$

onde $P(i \mid j)$ é a probabilidade condicional de observar o nucleotídeo $i$ do genoma $G$ alinhado com o nucleotídeo $j$ do genoma $G^{\prime}$, dado $j$ em $G^{\prime}$.

Para uma dada porcentagem de identidade alvo $\theta$, consideramos $P(j \mid j)=\theta$, e portanto $P(\neg j \mid j)=$ $1-\theta$, onde $P(\neg j \mid j)$ é a probabilidade condicional de observar qualquer outro nucleotídeo diferente de $j$ em $G$ alinhado com o nucleotídeo $j$ do genoma $G^{\prime}$, dado $j$ em $G^{\prime}$. Assim, para $i \neq j$,

$$
P(i \mid j)=P(\neg j \mid j)[F(i) / F(\neg j)]
$$

ou seja,

$$
P(i \mid j)=(1-\theta)[F(i) /(1-F(j))]
$$

Finalmente, utilizando $P(j \mid j)=\theta$ e as equações (3.2) e (3.3), temos

$$
P(i, j)=\left\{\begin{array}{lrr}
\theta F^{\prime}(j) & \text { se } & i=j \\
\{(1-\theta)[F(i) /(1-F(j))]\} F^{\prime}(j) & \text { se } & i \neq j
\end{array}\right.
$$

\footnotetext{
${ }^{6}$ Esse $\lambda$ da matriz não é o mesmo $\lambda$ parâmetro de uma distribuição de Gumbel. Preservamos no texto ambos como $\lambda$ devido a serem símbolos já amplamente utilizados na literatura de significância de escores.

${ }^{7}$ Na verdade, $P(i, j)=P(i \mid j) P(j)$, onde $P(j)=\sum_{i} P(i, j)$. Como é justamente $P(i, j)$ que se quer calcular, $P(j)$ pode ser aproximado pela distribuição de fundo do genoma $G^{\prime}, F^{\prime}(j)$.
} 
Utilizando os valores calculados a partir da equação 3.4 na equação 3.1, foi construída uma matriz utilizando $\theta=0.65$ (identidade alvo), $F$ igual à distribuição de fundo de $P$. falciparum $(F(A)=F(T)=0.403 ; F(C)=F(G)=0.097)$ e $F^{\prime}$ igual à distribuição de fundo de $P$. yoelii $\left(F^{\prime}(A)=F^{\prime}(T)=0.387 ; F^{\prime}(C)=F^{\prime}(G)=0.113\right)$. Utilizando $\lambda=0.225$ na equação 3.1 para reescalonar os valores, a matriz resultante é:

$$
S=\left[\begin{array}{cccc}
2 & -4 & -4 & -2 \\
-2 & 8 & -4 & -2 \\
-2 & -4 & 8 & -2 \\
-2 & -4 & -4 & 2
\end{array}\right]
$$

Assim como a matriz de similaridade, as penalidades de gaps também recebem uma interpretação:

$$
\begin{gathered}
\text { penalidade de abertura de gap }=\frac{1}{\lambda} \ln (P(\text { inserção })) \\
\text { e } \\
\text { penalidade de extensão de gap }=\frac{1}{\lambda} \ln (P(\text { extensão }))
\end{gathered}
$$

Dadas as penalidades e o $\lambda$ de um sistema de escore, é possível calcular as probabilidades de inserção e extensão. Desta forma, foram calculadas as probabilidades utilizadas pelo WU-BLASTN para uma matriz cuja identidade alvo é também 65\% (mesma identidade alvo utilizada para calcular a matriz de $P$. falciparum e P. yoelii) utilizando o $\lambda$ desta matriz. Essas probabilidades foram então utilizadas para calcular as novas penalidades, utilizando o novo $\lambda$ da matriz de $P$. falciparum e $P$. yoelii. Após arredondamento, os novos valores de penalidade são -9 , tanto para abertura quanto para extensão de gap.

\section{Estimação dos parâmetros de significância}

O procedimento descrito a seguir para estimação dos parâmetros estatísticos para alinhamentos com gaps foi baseado em [5].

Foram gerados dois conjuntos de seqüências aleatórias: um contendo seqüências com a mesma distribuição de fundo de $P$. falciparum e outro contendo seqüências com a mesma distribuição de fundo de $P$. yoelii. , Cada seqüência contém exatamente 400 bases. Para cada par de seqüências, foi obtido o escore do alinhamento ótimo utilizando a matriz $S$ e as penalidades de gaps calculadas como descrito anteriormente (utilizando como query uma seqüência com a mesma distribuição de fundo de $P$. falciparum e como banco de dados uma seqüência com a mesma distribuição de fundo de $P$. yoelii). Desta forma, foram obtidos mais de 20 milhões de escores (de mais de 20 milhões de alinhamentos ótimos). 
A estimação dos parâmetros de uma distribuição de Gumbel que se ajuste aos escores desses 20 milhões de alinhamentos ótimos foi realizada através do método de máxima verossimilhança descrito em [72]. Foram obtidos os estimadores $\hat{\lambda}=0.1347$ e $\hat{K}=0.0064$. A figura 3.1 mostra as freqüências dos escores dos alinhamentos e a curva de densidade de distribuição estimada. A região da curva que mais necessita de precisão é a sua cauda direita, onde se localizam os maiores escores. Note que a curva se ajusta bem aos pontos nessa região.

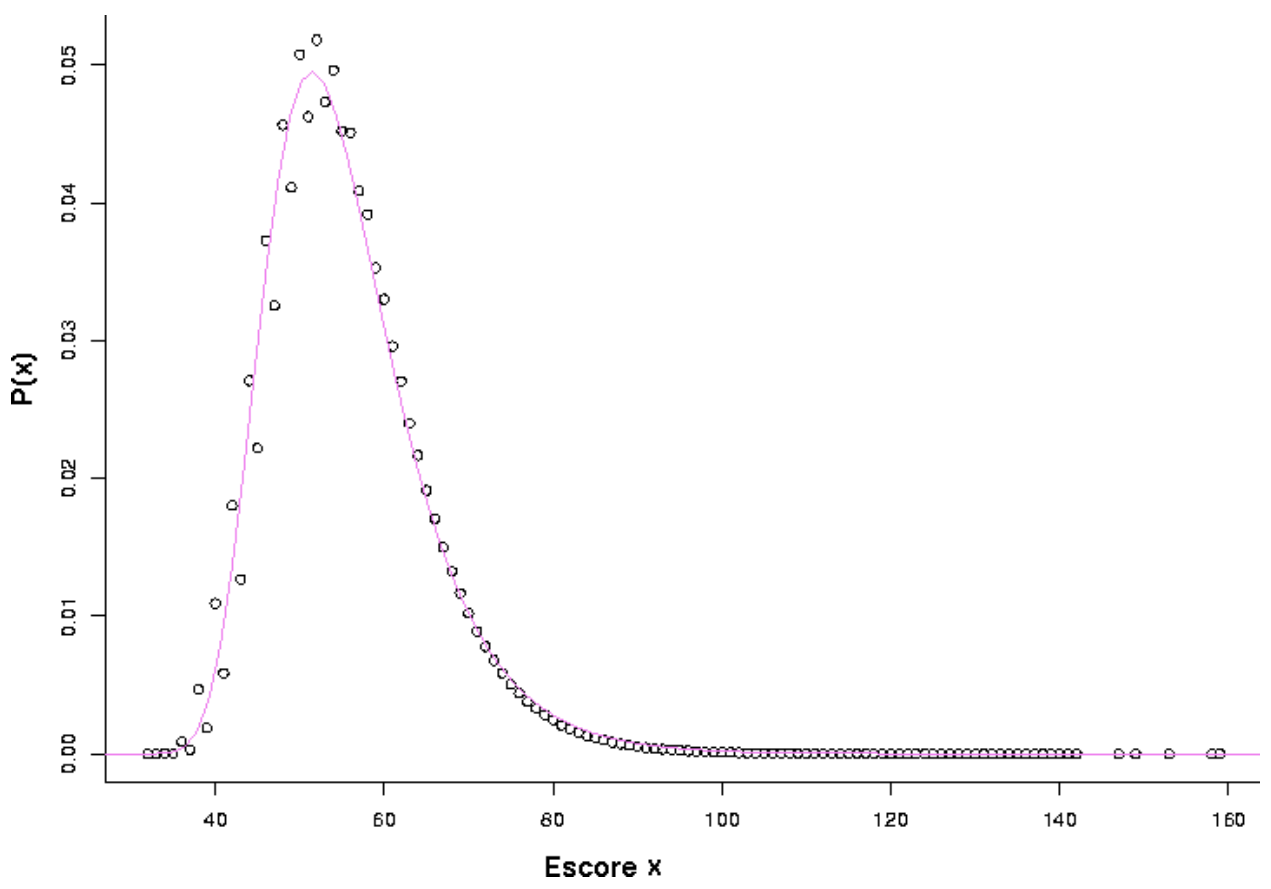

Figura 3.1: Função de densidade da distribuição de Gumbel estimada para a matriz $S$. Os círculos são as freqüências obtidas para cada escore dos 20.059.453 alinhamentos e a curva é a densidade estimada.

\section{Alinhamentos entre $P$. falciparum e $P$. yoelii}

A fim de aumentar a sensitividade da deteç̧ão de ncRNAs conservados em $P$. falciparum e $P$. yoelii, não foi suposta sintenia entre as duas espécies. Isto é, não foi esperado que ncRNAs conservados estejam localizados em uma mesma região cromossômica ou flanqueados pelos mesmos genes conservados entre as duas espécies. O genoma de $P$. falciparum foi dividido em seqüências de $50 \mathrm{~Kb}$ (50 mil bases) com sobreposição de $1 \mathrm{~Kb}$. Esses valores foram escolhidos de forma a balancear tempo de execução e uso de memória. Alinhamentos com uma seqüência query de $50 \mathrm{~Kb}$ são aceitáveis para alinhamentos locais utilizando WU-BLAST. A intersecção de 1Kb assume que, no pior caso, regiões conservadas só serão partidas se forem maiores que 1Kb. Sabemos que essa última 
situação pode ocorrer, porém a ferramenta eQRNA não necessita do alinhamento de uma seqüência inteira para classificá-la, e sim de um trecho onde seja possível detectar padrões de mutação. Estas seqüências foram alinhadas contra o genoma de $P$. yoelii utilizando a ferramenta WU-BLAST com os parâmetros de sistema de escore e de significância aqui calculados.

\subsubsection{Análise dos alinhamentos}

Os alinhamentos foram filtrados de forma a serem analisados apenas aqueles de maior escore para cada região genômica de $P$. falciparum, que possuam identidade mínima de $60 \%$ e com tamanho mínimo de 20 colunas. Embora uma matriz tenha uma porcentagem de identidade alvo, os alinhamentos obtidos possuem uma variedade de porcentagem de identidade. Como a matriz utilizada foi de $65 \%$, foi considerado o limiar de $60 \%$. O tamanho mínimo de 20 colunas é devido ao fato de que os menores ncRNAs conhecidos, microRNAs, possuem aproximadamente 20 nucleotídeos. Essa filtragem foi feita utilizando o script blastn2qrnadepth.pl que acompanha a ferramenta eQRNA.

Os alinhamentos que atenderam a este requisito foram analisados pelo programa eqrna. Foram obtidas as localizações genômicas originais desses alinhamentos, e os alinhamentos sobrepostos e/ou consecutivos foram agrupados em regiões conservadas ${ }^{8}$. As seqüências de $P$. falciparum das regiões conservadas classificadas como ncRNAs foram comparadas com a anotação de genes de $P$. falciparum disponível no banco de dados PlasmoDB 5.0 [203]. Nesta anotação há a localização de 50 ncRNAs, não contendo as predições das RNases P e MRP [204] e do SRP RNA [224]. As seqüências destes 3 RNAs foram obtidas dos locais descritos em [204, 224] e comparadas com as seqüências de $P$. falciparum envolvidas nas regiões conservadas classificadas como ncRNAs.

\subsection{Resultados}

Os resultados estão resumidos na figura 3.2. Foram produzidos no total 521.387 alinhamentos entre $P$. falciparum e $P$. yoelii. Após a filtragem por cobertura, E-value, identidade e tamanho, restaram 58.761 alinhamentos. Agrupados de acordo com suas localizações genômicas, formam 10.183 regiões conservadas, dos quais 2.890 foram classificados como RNA. Porém, muitos destes ncRNAs hipotéticos sobrepõem-se com genes já anotados no PlasmoDB: 2.524 com genes de proteínas (das

\footnotetext{
${ }^{8}$ Uma vez que os alinhamentos foram realizados com subseqüiências do genoma com sobreposição de $1 \mathrm{~K}$, as localizações das seqüências não se referem às suas localizações originais no genoma. Outro ponto é que essa sobreposição de seqüências pode causar sobreposição de alinhamentos. Além disso, o programa eqrna analisa os alinhamentos utilizando janelas, e portanto janelas consecutivas pertencem ao mesmo candidato. Portanto, para obter o número real de candidatos, é necessário agrupar alinhamentos sobrepostos e janelas adjacentes. O agrupamento é feito com o script loci_from_gff.pl do pacote do eQRNA.
} 
quais 1.884 são hipotéticas, 450 são putativas e 190 confirmadas) e 42 com genes de ncRNAs. Do conjunto de 3 genes preditos em trabalhos específicos (não presentes na anotação do PlasmoDB), RNases P e MRR e o SRP RNA, somente a RNase MRP foi classificada como ncRNA. Considerando esse dado, o número total de regiões conservadas classificadas como ncRNAs que possuem anotação ou predição de ncRNAs é 43, o que significa $81 \%$ dos ncRNAs anotados ou preditos. Os 323 restantes são candidatos a ncRNAs.

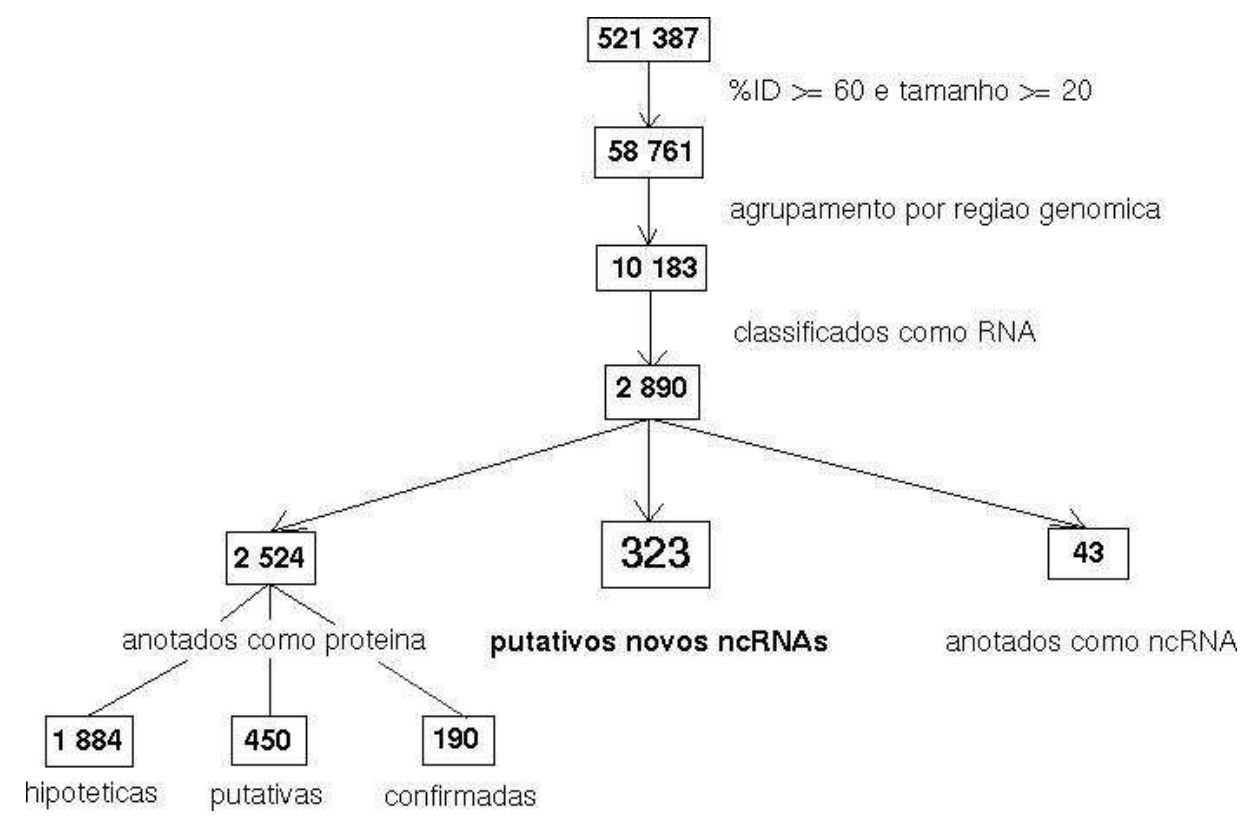

Figura 3.2: Processo de análise dos alinhamentos. 


\section{Análises e buscas preliminares de TERCs}

Este capítulo descreve as análises preliminares realizadas durante a primeira fase desse projeto. Estas análises tiveram três objetivos: (i) pesquisar características conservadas de TERCs, (ii) verificar se essas características poderiam ser utilizadas com sucesso como critério de busca por estratégias simples e/ou ferramentas já existentes e (iii) propor uma abordagem gramatical para a caracterização de TERCs.

Para cumprir os objetivos (i) e (ii), foi utilizada uma abordagem heurística analisando sinais da seqüência primária e uma abordagem termodinâmica analisando características de estrutura secundária. A seção 4.1 descreve como essa estratégia foi utilizada para analisar os TERCs conhecidos e para predizer candidatos em Plasmodium falciparum. A seção 4.2 descreve estudos preliminares da aplicação de gramáticas estocásticas livres de contexto na caracterização de TERCs.

\subsection{Aproximação heurística e termodinâmica}

Foi utilizado como hipótese de trabalho que o TERC de $P$. falciparum deve ser mais semelhante aos TERCs de ciliados do que aos de vertebrados e leveduras. P. falciparum é um organismo unicelular, estando mais distante filogeneticamente de ser um vertebrado. Com relação a leveduras, seus TERCs parecem ser uma exceção em termos de tamanho de seqüência. Algumas leveduras também possuem repetição telomérica maior que o usual. A repetição de Candida maltosa, por exemplo possui 23 bases [109]. Além disso, mesmo os dois grupos de leveduras com TERC conhecido (7 Saccharomyces [56] e 6 Kluyveromyces [268]) possuem uma alta divergência entre si, de forma a até mesmo não ser possível alinhar seqüências desses dois diferentes grupos. As espécies de Saccharomyces se dividem em três grupos filogenéticos: sensu stricto, sensu lato e petite negative. Somente são conhecidos TERCs do primeiro grupo. Abordagens biológicas de identificação de TERCs em espécies dos demais grupos com base nas seqüências de sensu stricto falharam provavelmente devido à divergência dos TERCs entre os grupos. 
Para identificar candidatos a TERCs no genoma de Plasmodium falciparum, uma possível estratégia é detectar ocorrências do template e analisar uma região ao redor desse template em busca de características comuns a TERCs. O primeiro passo nesta direção foi o estudo de quais características são conservadas entre os TERCs, tanto em suas seqüências quanto em suas estruturas secundárias, a fim de definir quais características seriam relevantes para serem utilizadas nesta análise. Além disso, como cada característica poderia possuir um diferente nível de conservação, seria necessário definir pesos diferentes a essas características na análise de seqüências candidatas.

\subsubsection{Análise de TERCs}

A ênfase desse estudo foi TERCs de ciliados. Algumas análises, porém, conforme descrito em cada seção, foram também realizadas com TERCs de vertebrados a fim de detectar se há características conservadas nestes dois grupos, indicando características de maior relevância. Não foram realizadas análises utilizando TERCs de leveduras pois, além dos motivos citados acima, o comprimento de suas seqüências ultrapassava o limite de algumas ferramentas ${ }^{1}$. As seqüências de TERCs analisadas foram obtidas do Genbank [191], sendo 22 de ciliados e 36 de vertebrados.

\section{Sinais da seqüência primária}

A literatura menciona algumas regiões conservadas em um subconjunto de TERCs de ciliados $[54,158,179,196,222,261]$. Foi então realizada uma análise para verificar se essas regiões eram conservadas entre todos os TERCs de ciliados conhecidos. Além das regiões conservadas, foi analisado se havia uma semelhança entre o conteúdo GC dessas seqüências. Para algumas dessas características, foi também verificada a existência de conservação entre TERCs de vertebrados.

\section{Extensão do template}

Como descrito na seção 1.3.3, o template deve possuir o molde para a repetição telomérica e mais uma extensão que permita o anelamento entre parte do template e a extremidade telomérica sendo sintetizada. Embora seja utilizada a expressão "um template e meio" [186], foi verificado que, entre ciliados e vertebrados, o tamanho mínimo dessa extensão é de 1 nt em cada lado.

\footnotetext{
${ }^{1}$ Foi o caso do MFOLD, cujo uso era fundamental para esse estudo. O uso dessa ferramenta será discutido adiante.
} 


\section{Região 5' próxima ao template}

Em alguns ciliados a seqüência [C]UGUCA apresenta-se conservada posicionada exatamente 2 nucleotídeos antes do template [158, 179, 180, 222]. Dessa forma, foi analisada uma seqüência de 12 bases exatamente antes do template de todos os TERCs de ciliados e vertebrados. Essas seqüências foram alinhadas com o consenso [C]UGUC[A] utilizando a ferramenta de alinhamento local cross_match ${ }^{2}[47]$.

Como mostra a tabela 4.1, dos 22 ciliados analisados todos apresentaram bons alinhamentos com a seqüência consenso. Os escores variaram de 4 a 6 (5.27 em média) envolvendo de 4 a 6 bases (5.27 em média), e distantes do template em 1 a 3 bases (1.95 em média). Dos 36 vertebrados, 33 foram analisados (para os demais TERCs de vertebrados, o seqüenciamento do transcrito só foi realizado a partir da região de template) e apenas 11 apresentaram alinhamentos similares aos dos ciliados, porém distantes do template em 1 a 7 bases (2.73 em média). Esses resultados mostram que essa seqüência é realmente conservada entre TERCs de ciliados, mas não é um consenso entre vertebrados. Portanto, a presença dessa seqüência pode ser utilizada como um característica classificatória para candidatos a TERCs em $P$. falciparum, mas sua ausência não pode desqualificar um candidato.

Tabela 4.1: Resultados de alinhamentos locais entre 12 bases upstream do template telomérico de ciliados e vertebrados contra o consenso [C]TGTCA.

\begin{tabular}{|l|c|c|c|c|c|c|c|c|}
\hline & & & \multicolumn{2}{|c|}{ Score } & \multicolumn{2}{c|}{ \# de bases } & \multicolumn{2}{c|}{ Distância do template } \\
\hline & \#seqs analisadas & \#alin. & Média & DP & Média & DP & Média & DP \\
\hline Ciliados & 22 & 22 & 5.27 & 0.94 & 5.27 & 0.94 & 1.95 & 0.49 \\
Vertebrados & 33 & 11 & 4.09 & 0.3 & 4.27 & 0.65 & 2.73 & 1.95 \\
\hline
\end{tabular}

Tamanhos das regiões transcritas 5' e 3' do template

Na busca por candidatos a TERC aqui proposta, será analisada uma seqüência compreendida dentro de uma janela ao redor das ocorrências genômicas do template. É necessário portanto delimitar tamanhos máximos upstream e downstream (em relação ao template que definam essa janela. Analisando os TERCs conhecidos, foi verificado que o tamanho médio da porção upstream de TERCs de ciliados é de 41.7 bases, com valor máximo de 45 . Já na porção downstream o tamanho médio é de 122.35 , com valor máximo de 146 . O tamanho de janela foi então definido como $[50 ; 150]^{3}$.

\footnotetext{
${ }^{2}$ Parâmetros -raw -minmatch 3 -minscore 3 -penalty -1 .

${ }^{3} \mathrm{~A}$ janela $[x ; y]$ define uma seqüência com $x$ bases antes do template, o template e mais $y$ bases após o template.
} 


\section{Regiões conservadas na região 5' não transcrita}

Apesar de não ser conhecido qual RNA polimerase transcreve os TERCs de ciliados, sabe-se que alguns desses TERCs possuem duas regiões razoavelmente conservadas na porção 5' antes do início da transcrição: (G|A)ACCCATAA(T|A)5 na região localizada aproximadamente de -63 a -50 e (T|A)TTA(T|A) localizada aproximadamente de -28 a -23 [158] (considerando a posição +1 como sendo o início de transcrição). Como muitas das seqüências de TERCs de ciliados utilizadas nesta análise são amplificações de locus genômicos, foi possível procurar esses dois padrões em suas regiões não transcritas. Isso foi feito alinhando localmente a região não transcrita com os padrões mencionados utilizando a ferramenta cross_match ${ }^{4}$.

Das 22 seqüências de TERCs de ciliados, 16 possuem a região 5' não transcrita com pelo menos 63 bases (posição do padrão mais distante). Destas, todas apresentaram um bom alinhamento com a seqüência consenso (G|A)ACCCATAA(T|A)5 na posição esperada. Essa característica, porém, não é conservada em vertebrados (tabela 4.2). Já o padrão (T|A)TTA(T|A) não é tão conservado nem mesmo em ciliados, sendo encontrado em apenas 6 TERCs (tabela 4.3). Essa região parece ser ainda menos conservada em vertebrados, onde foi encontrada em apenas um TERC.

Tabela 4.2: Resultados dos alinhamentos da região 5' não transcrita com o padrão (G|A)ACCCATAA(T|A)5. A distância da posição -63 indica quantas bases há de diferença entre a posição do alinhamento e a posição esperada do padrão (G|A)ACCCATAA(T|A)5 (-63).

\begin{tabular}{|l|c|c|c|c|c|c|c|}
\hline & & \multicolumn{2}{|c|}{ Score } & \multicolumn{2}{c|}{ \# de bases } & \multicolumn{2}{c|}{ Distância da posição -63} \\
\hline Alinhamentos & \#alin. & Média & DP & Média & DP & Média & DP \\
\hline Ciliados & 16 & 12.75 & 1.77 & 13.50 & 0.89 & 0.77 & 0.75 \\
Vertebrados & 21 & 4.95 & 0.80 & 7.24 & 2.36 & 23.71 & 13.94 \\
\hline
\end{tabular}

\section{Conteúdo GC total}

Os pareamentos em uma estrutura secundária são mais estáveis quando compostos por pares G-C. Assim o conteúdo GC pode fornecer uma idéia, embora grosseira, da estabilidade de uma estrutura. Foi analisado se havia alguma semelhança entre a porcentagem de bases $\mathrm{G}$ e $\mathrm{C}$ na região transcrita de TERCs. TERCs de ciliados apresentaram conteúdo GC médio de $38.35 \%$ com desvio padrão de 4.34. Os de vertebrados apresentaram conteúdo GC superior, com média de $64.77 \%$ e desvio padrão de 5.11. Essa diferença de composição entre TERCs de ciliados e de vertebrados pode

\footnotetext{
${ }^{4}$ Utilizamos os parâmetros -raw -minmatch 3 -minscore 3 -penalty -1.
} 
Tabela 4.3: Resultados do alinhamento da região 5' não transcrita com o padrão (T|A)TTA(T|A). A distância da posição -28 indica quantas bases há de diferença entre a posição do alinhamento e a posição esperada do padrão (-28). A coluna de "Distância entre padrões" indica quantas bases há de diferença na distância esperada (35) entre os padrões (G|A)ACCCATAA(T|A) 5 e (T|A)TTA(T|A).

\begin{tabular}{|l|c|c|c|c|c|c|c|c|c|}
\hline & & \multicolumn{2}{|c|}{ Score } & \multicolumn{2}{c|}{ \# de bases } & \multicolumn{2}{c|}{$\begin{array}{c}\text { Distância da } \\
\text { posição }-28\end{array}$} & \multicolumn{2}{c|}{$\begin{array}{c}\text { Distância } \\
\text { entre padrões }\end{array}$} \\
\hline Alinhamentos & \#alin. & Média & DP & Média & DP & Média & DP & Média & DP \\
\hline Ciliados & 6 & 4.83 & 0.41 & 4.83 & 0.41 & 4 & 3.22 & 3.5 & 3.27 \\
Vertebrados & 1 & 5 & 0 & 5 & 0 & 0 & 0 & 0 & 0 \\
\hline
\end{tabular}

ser reflexo do baixo conteúdo GC estimado para os ciliados (em alguns organismos $15 \%$ nas regiões intergênicas e $40 \%$ nas regiões gênicas).

\section{Características de estrutura secundária}

TERCs de ciliados possuem uma estrutura secundária consenso [222]. Para verificarmos se essa estrutura é realmente conservada também naqueles TERCs sem estrutura específica publicada, utilizamos a ferramenta MFOLD para predizer suas estruturas, e então comparar com a consenso. Foi verificado que a estrutura secundária é, de modo geral, conservada entre todos os TERCs de ciliados.

Trabalhos comparativos envolvendo algumas espécies de ciliados indicam regiões conservadas em determinadas localizações da estrutura secundária [158, 179, 180, 222]. Essas regiões, indicadas por círculos na figura 4.1, são:

- seqüência [A]AUU[C] entre o pseudo-nó e a hélice III;

- seqüência UU[C]AAA no loop da hélice III;

- seqüências AAA e UUUG como limite do último bojo da hélice IV;

- seqüência CCUCU como sendo as últimas bases pareadas em uma hélice (hélice IV);

- cauda de 4 U's finalizando o TERC (extremidade 3').

No entanto, a maioria destas características não são consenso entre ciliados. A seqüência UUUG que aparece como limite do último bojo da hélice IV é encontrada somente em mais alguns TERCs, na maioria de Tetrahymena. O que realmente se destacou como um padrão foi a cauda de pelo menos 2 U's (4 ou 5 na maioria, ou mais em algumas espécies) na extremidade 3' do TERC. 


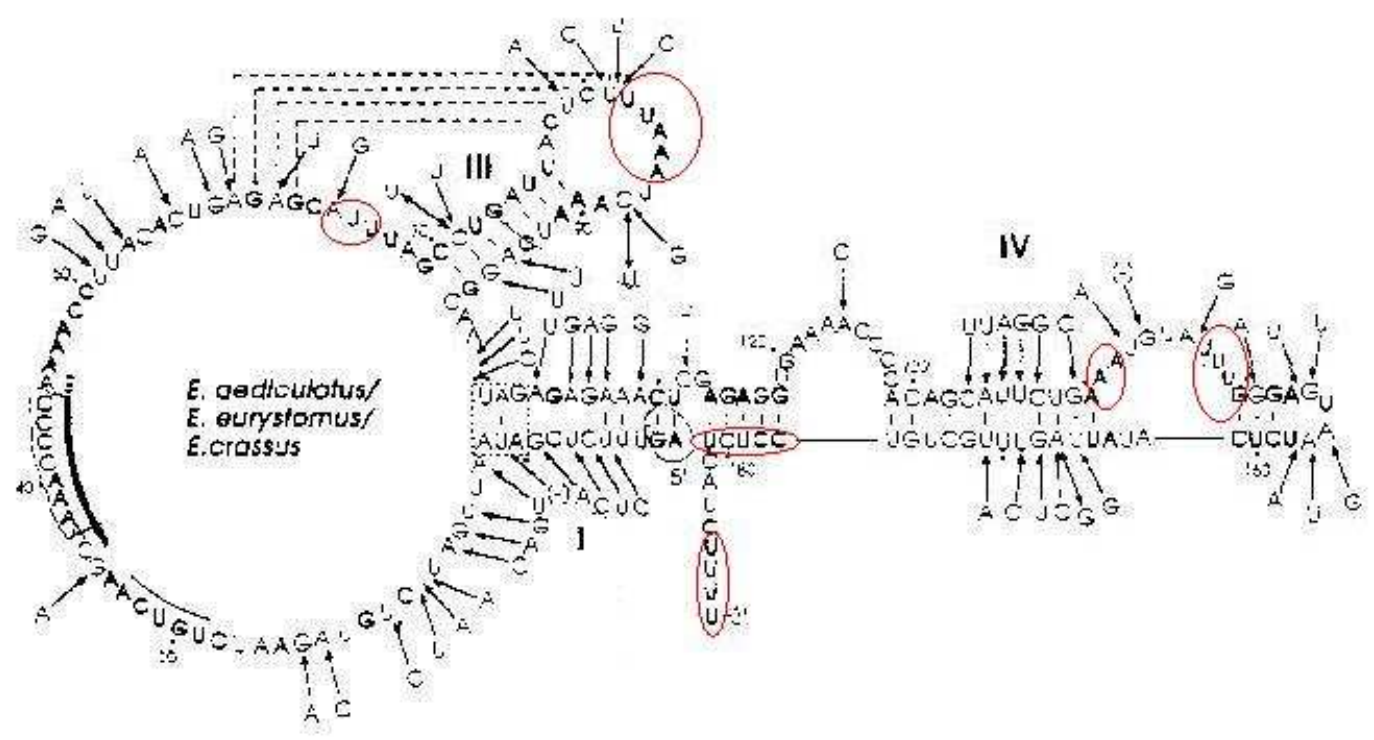

Figura 4.1: Estrutura consenso de TERCs de 3 espécies de Euplotes. Linhas pontilhadas indicam formação de pseudo-nó. Figura adaptada de [158].

\section{Análise de dot-plots de energia}

Para predizer a estrutura secundária das seqüências candidatas de $P$. falciparum, foi utilizada a ferramenta MFOLD ${ }^{5}$ [301], uma ferramenta referência que tem sido utilizada inclusive em trabalhos envolvendo TERCs [35, 158, 179, 180, 222].

Antes de aplicar essa ferramenta sobre as seqüências candidatas de $P$. falciparum, duas perguntas deveriam ser respondidas:

1. Qual a qualidade das predições realizadas pelo MFOLD para TERCs?

2. Como a predição pode ser afetada por bases extras nos extremos 5' e 3', uma vez que não podemos assegurar os limites de início e fim das seqüências candidatas?

Para responder a primeira pergunta, as predições de todos TERCs de ciliados foram comparadas com suas estruturas publicadas (quando disponíveis) ou com a estrutura consenso, e foi verificado

\footnotetext{
${ }^{5}$ O MFOLD utiliza parâmetros termodinâmicos para calcular a estrutura com energia livre mínima [301].
} 
que há uma razoável qualidade de predição. Para tentar responder a segunda pergunta, várias predições de estruturas dos TERCs foram realizadas variando os tamanhos dos extremos 5' e 3' de suas seqüências $^{6}$. Foram utilizados 3 diferentes tamanhos de janelas: [50;150], [100;220] e [440;350].

Uma vez que essa variação nos tamanhos dos extremos resulta em muitas predições, era necessário utilizar uma forma de visualização rápida do padrão de estrutura como um todo. Por isso a representação de estruturas por dot-plots de energia foi utilizada, gerada pela própria ferramenta MFOLD.

Um dot-plot de energia é uma representação gráfica da estrutura secundária de uma seqüência em uma matriz $n \times n$, onde $n$ é o tamanho da seqüência (figura 4.2). Cada coluna representa uma posição da seqüência, e cada linha representa uma posição do reverso complementar dessa seqüência. Um ponto é colocado na posição $(\mathrm{x}, \mathrm{y})$ da matriz se as posições $\mathrm{x}$ e y da seqüência estão pareadas na estrutura secundária predita. O MFOLD coloca na metade inferior a representação da estrutura de energia livre mínima (ótima). Na metade superior são colocadas tanto a representação da estrutura ótima quanto de sub-ótimas, utilizando diferentes cores para cada estrutura. Desta forma, uma estrutura secundária forma um desenho nessa matriz.

A figura 4.2 mostra o dot-plot do TERC de Euplotes crassus, que se assemelha bastante com os dot-plots dos TERCs dos demais ciliados.

Foi verificado se era possível visualizar o desenho esperado para a seqüência original do TERC na matriz gerada para todas as variações de tamanho. Apenas $20 \%$ dos TERCs de ciliados apresentaram falta de estabilidade no padrão de dot-plot.

\subsubsection{Busca no genoma do Plasmodium falciparum e ordenação preliminar}

Candidatos a TERC em Plasmodium falciparum foram extraídos do genoma. Para isso, os telômeros foram previamente mascarados utilizando a ferramenta cross_match [47] e então foram identificadas todas as ocorrências das possíveis seqüências template para as duas repetições mais freqüentes em $P$. falciparum (TTTAGGG e TTCAGGG), contendo extensão de pelo menos 1 base de cada lado do template (baseado nos resultados das análise de TERCs de ciliados). Foram analisadas as regiões em volta desse template.

Foram encontrados 59 candidatos iniciais. Destes, 4 estão localizados em posições consecutivas no genoma ${ }^{7}$ e 15 possuem outras anotações ( 2 rRNAs 5.8S, 1 RNA mitocondrial e 12 proteínas),

\footnotetext{
${ }^{6}$ Isso foi possível pelo fato de que as seqüências de TERCs depositadas no NCBI são, em sua maioria, seqüências genômicas que contém não apenas o TERC mas também regiões não transcritas nos dois extremos. Foi então utilizado o próprio TERC (região transcrita) como seqüência mínima e toda a seqüência genômica como seqüencia máxima.

${ }^{7}$ Este é um exemplo de de região template-repetitiva. Fenômenos como esse podem ocorrer devido a recombinações
} 
Fold of Euplotes crassus at $37 \mathrm{C}$.

$\delta G$ in Plot File $=2.2 \mathrm{kcal} / \mathrm{mole}$

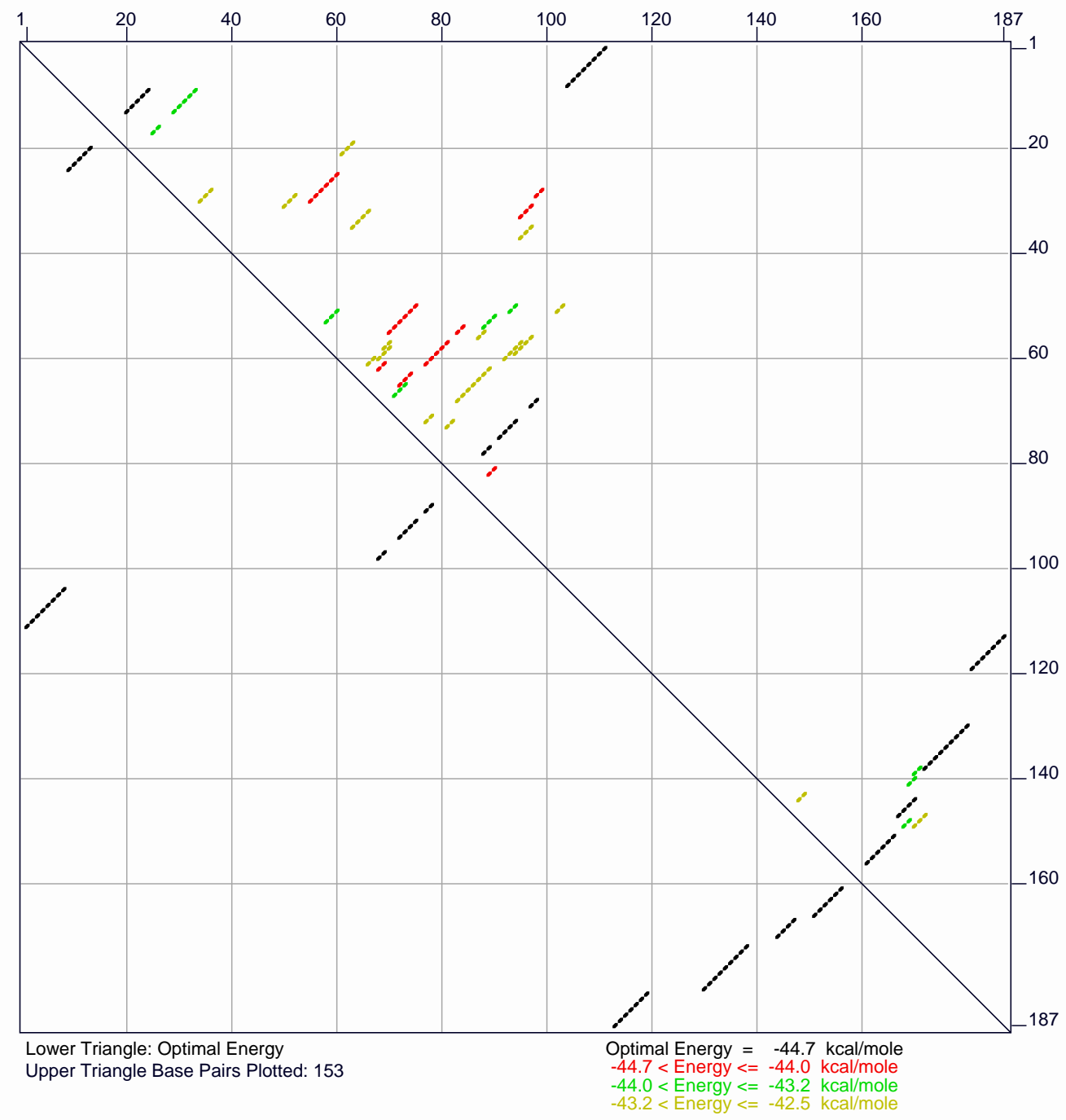

Figura 4.2: Dot-plot de TERC de Euplotes 
restando 40 candidatos.

Estes 40 candidatos foram analisados de acordo com as várias características analisadas em TERCs. As análises para detecção de regiões conservadas foram realizadas como nos TERCs de ciliados. A análise da estrutura secundária foi realizada utilizando apenas as seqüências definidas pela janela [50;150] (por ser essa a dimensão aproximada da janela para TERCs de ciliados). Na estrutura predita foram verificadas:

- a presença de hélices na configuração esperada;

- a presença das seqüências conservadas nas determinadas localizações da estrutura secundária;

- a possibilidade de formação de um pseudo-nó no local esperado.

Os candidatos foram inicialmente classificados de acordo com a qualidade da estrutura secundária predita, recebendo um escore de 0 a 5 por meio de uma avaliação visual. Candidatos com o mesmo escore foram então classificados pela similaridade de regiões conservadas. O conteúdo GC não foi usado para classificação devido ao alto conteúdo AT de P. falciparum.

Os 3 primeiros candidatos foram selecionados para uma validação biológica. São eles por nós identificados pelos números 12, 29 e 44. O candidato número 12 foi o que apresentou maior compatibilidade com os padrões levantados nas análises realizadas até aqui. A estrutura secundária predita deste candidato se assemelha bastante às estruturas de TERCs de ciliados preditas pelo MFOLD, conforme é possível notar na figura 4.3. A figura mostra, à esquerda, a estrutura predita de TERC de Colpidium e à direita a do candidato 12. Com relação ao consenso [C]UGUC[A] localizado 2 bases antes do template em TERCs de ciliados, este candidato apresenta uma seqüência muito semelhante (UGUGA) a exatamente 2 bases antes do que seria o template. O candidato 12 também apresenta a seqüência UUUG no último loop da hélice IV e a cauda poli-U.

\section{Experimento de validação biológica}

\section{Northern blot}

A fim de verificar se um desses candidatos era uma seqüência transcrita, foi realizado um experimento de Northern blot para as seqüências candidatas número 12, 29 e 44. Para cada uma delas, foram desenhados primers para amplificar uma região de aproximadamente 100 bases em torno da repetição telomérica. As seqüências amplificadas foram utilizadas como sonda no Northern blot. A seqüência da TERT (componente proteico já caracterizado em P. falciparum) foi utilizada como com regiões teloméricas [81], ou simplesmente por ser uma região repetitiva que cuja seqüência coincide com a repetição telomérica. 

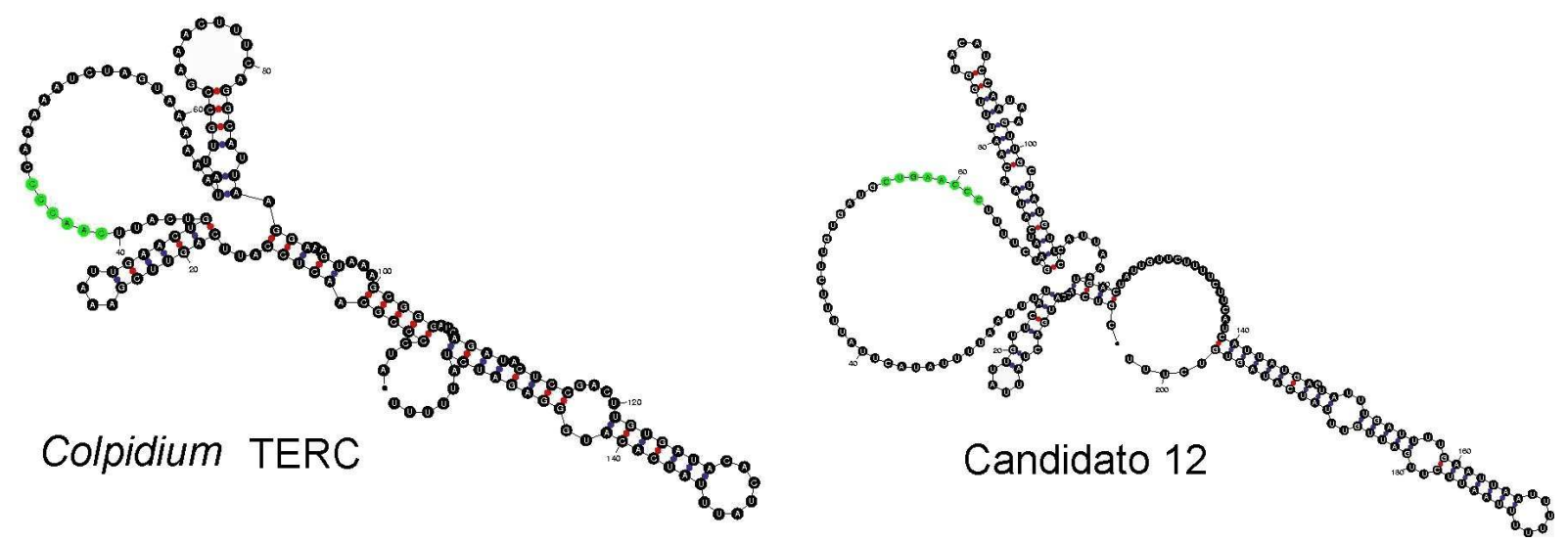

Figura 4.3: Estruturas secundárias preditas pelo mfold. À esquerda TERC de Colpidium; à direita o candidato 12.

controle positivo $^{8}$. As seqüências definidas pelos primers foram amplificadas com sucesso, e então marcadas. No entanto, além do controle positivo TERT, só foi possível visualizar um fragmento fraco de aproximadamente $5 \mathrm{~kb}$. Este é o tamanho de uma proteína hipotética anotada antisenso à seqüência candidata.

\section{$R T-P C R$}

Por se tratar de um método mais sensível que o Northern blot na detecção de RNAs em pequena quantidade, foi realizado um RT-PCR ${ }^{9}$. Foram utilizados os mesmos primers utilizados no experimento de Northern blot. Os controles positivos foram a TERT e a MSP1 (merozoite surface protein 1). O controle negativo foi uma mistura de RNAs e os reagentes utilizados no RTPCR, porém sem a enzima transcriptase reversa ${ }^{10}$. Como esperado, os controles positivos TERT e MSP1 foram amplificados. Desta vez, a candidata 12 foi também amplificada. O fragmento foi seqüenciado confirmando que se tratava da seqüência esperada. As bandas mais fracas observadas nos controles negativos e nas demais candidatas são amplificações não específicas como dímeros de primers ${ }^{11}$. A figura 4.4 mostra os resultados do experimento.

\footnotetext{
${ }^{8}$ Este experimento foi realizado por Mauro Ferreira de Azevedo, na época aluno de Doutorado em Biologia orientado pelo Professor Hernando A. del Portillo.

${ }^{9}$ Este experimento foi também realizado por Mauro Ferreira de Azevedo.

${ }^{10}$ Enzima que faz uma cópia de DNA a partir de RNA, a partir do qual seguem-se os ciclos convencionais de PCR.

${ }^{11}$ A porção 3' de um primer pode parear com a porção 3' de outro primer. Os pares de primers podem ser estendidos formando dímeros de primer. Esses dímeros podem ser estendidos em ciclos subseqüentes de reações de PCR [200].
} 

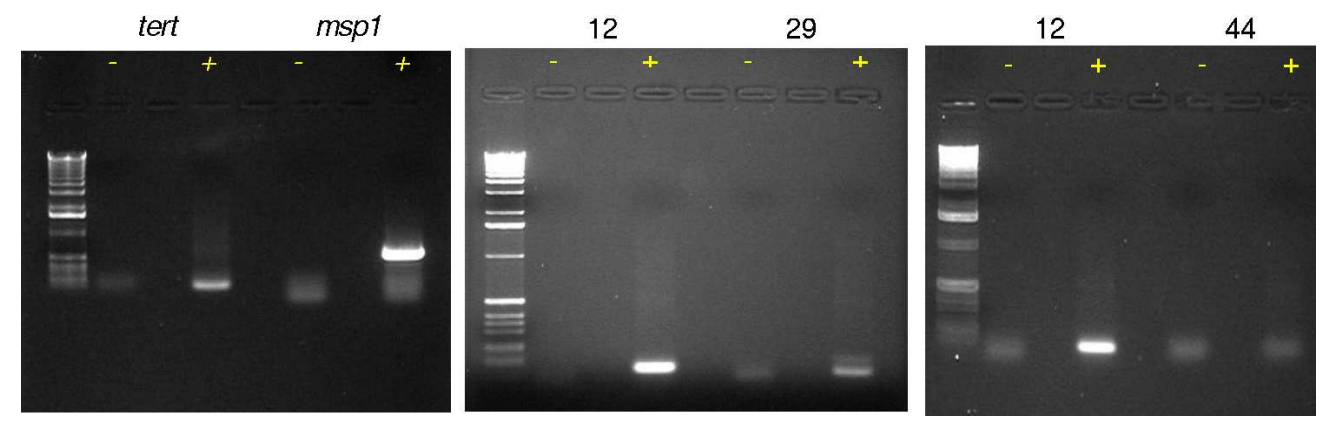

Figura 4.4: RT-PCR de msp1 e tert (controles positivos) e seqüências 12, 29 e 44 (TERCs candidatos).

\section{$5^{\prime}-R A C E$}

Para detectar o tamanho e a seqüência exatos da extremidade 5' do transcrito amplificado por RT-PCR, foram realizadas duas tentativas de $\mathbf{5}^{\prime} \mathbf{R A C E} \mathbf{E}^{12}$.

Na primeira tentativa, foram utilizadas as temperaturas de $94^{\circ} \mathrm{C}$ para denaturação, $60^{\circ} \mathrm{C}$ para anelamento e $72^{\circ} \mathrm{C}$ para extensão. Era esperado um fragmento de aproximadamente $200 \mathrm{bp}$. Foram seqüenciados os produtos dos fragmentos 1, 2 e 3 exibidos na figura 4.5A. As seqüências amplificadas referem-se a um $18 \mathrm{~S}$ rRNA, uma proteína hipotética e uma ORF desconhecida. Infelizmente, não foi encontrada nenhuma seqüência referente ao candidato 12 .

$\mathrm{Na}$ segunda tentativa foram realizados 3 experimentos variando a temperatura de anelamento: $55^{\circ} \mathrm{C}, 60^{\circ} \mathrm{C}$ e $65^{\circ} \mathrm{C}$, a fim de verificar se essa temperatura estaria influenciando o anelamento dos primers. Foram seqüenciados os fragmentos 1, 2 e 3 exibidos na figura 4.5B. O primeiro corresponde a um rRNA $18 \mathrm{~S}$, e os outros dois fragmentos a seqüências de proteína, mas novamente o candidato 12 não foi amplificado.

\subsection{Análise gramatical}

Gramáticas livres de contexto estocásticas (GLCEs) são modelos probabilísticos capazes de caracterizar seqüências de RNAs e suas estruturas secundárias [243]. Nosso trabalho anterior foi incentivo para que esses modelos fossem utilizados na caracterização de TERCs [170].

INFERNAL [76] é uma ferramenta referência na identificação de ncRNAs, implementando um modelo equivalente a GLCEs [71]. No entanto, sua aplicação direta em Plasmodium falciparum não produziu resultados satisfatórios. As regras gramaticais inferidas pelo INFERNAL permitem que

\footnotetext{
${ }^{12}$ Este experimento foi realizado por Márcio Massao Yamamoto do laboratório do Professor Hernando A. del Portillo.
} 
A

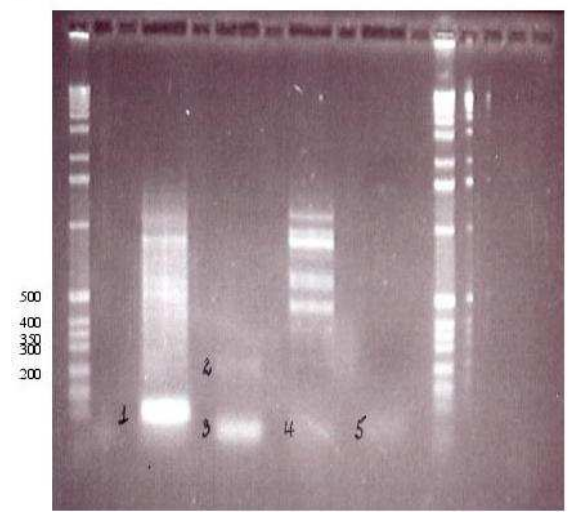

B

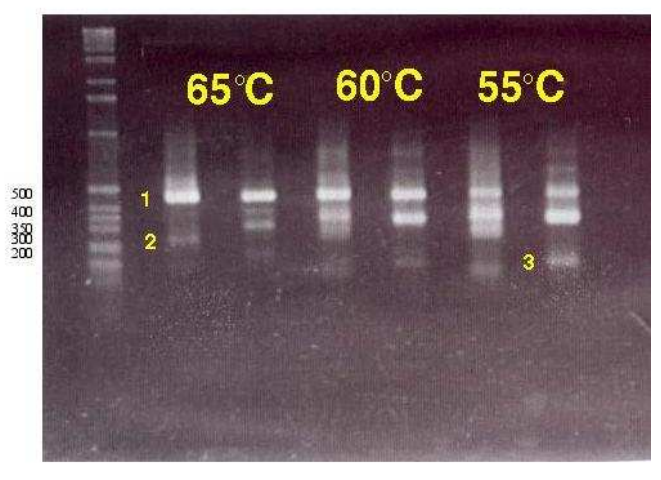

Figura 4.5: Duas execuções de 5'-RACE. A: Temperatura de $60^{\circ} \mathrm{C}$ de anelamento. B: Uso de três temperaturas de anelamento: $55^{\circ} \mathrm{C}, 60^{\circ} \mathrm{C}$ e $65^{\circ} \mathrm{C}$.

qualquer seqüência seja reconhecida pelo analisador sintático, mesmo que a amostra de treinamento seja $100 \%$ conservada. Uma seqüência é então classificada por seu escore. Para que qualquer seqüência seja reconhecida, as regras gramaticais possuem um grande número de parâmetros que precisam ser estimados a partir da amostra de treinamento, o que pode ser um problema quando a amostra de treinamento é pequena. Essas regras são geradas automaticamente, não permitindo a criação de regras gramaticais específicas para regiões altamente conservadas como, por exemplo, o template telomérico de TERCs. Por esse motivo, foi iniciada uma abordagem gramatical no sentido de desenhar gramáticas manualmente, de forma a serem o mais enxutas possível.

Utilizando as informações obtidas na fase de análise heurística e termodinâmica descrita na seção anterior, foram iniciados experimentos de modelagem de uma gramática livre de contexto estocástica para a caracterização de seqüências de TERC. Essa gramática foi utilizada para construir um classificador que, dada uma seqüência qualquer, classifica essa seqüência como um possível TERC ou não. Essa classificação vem acompanhada de um escore, que pode ser utilizado para ranquear seqüências candidatas.

\subsubsection{Métodos}

Para construir esses classificadores baseados em gramáticas, foi utilizado um arcabouço de geração automática dos mesmos. Esse arcabouço havia sido implementado durante o programa de mestrado [170].

O processo de geração e aplicação de um classificador, esquematizado na figura 4.6, segue os seguintes passos: 


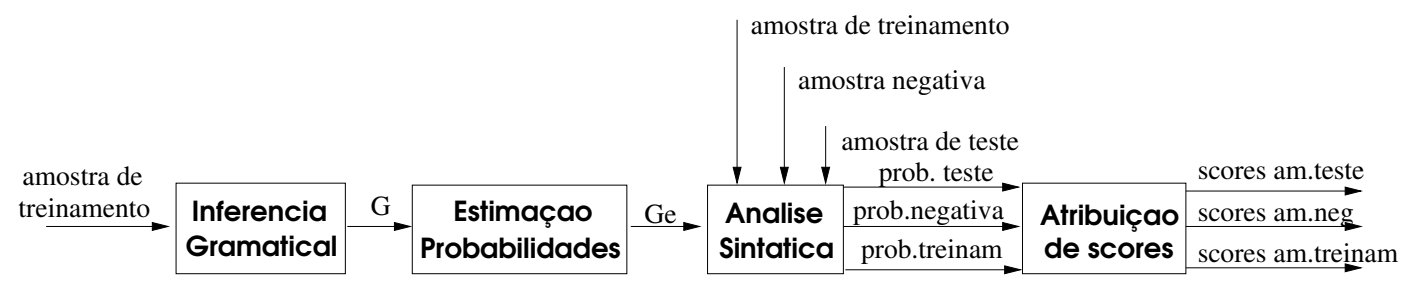

Figura 4.6: Processo de geração de um classificador

1. Geração de uma gramática: nesta fase, uma gramática é gerada automaticamente ${ }^{13}$ ou desenhada manualmente.

2. Estimação de probabilidades: A gramática gerada pela fase anterior pode ser estocástica ou não. Nesta etapa, essa gramática tem suas probabilidades estimadas (ou reestimadas) a partir de uma amostra de treinamento.

3. Geração de um analisador sintático estocástico: Um analisador sintático estocástico é um programa que recebe como entrada uma seqüência e uma gramática estocástica, e gera como saída a probabilidade dessa seqüência ser gerada por essa gramática. Com a finalidade de obter melhor desempenho, nesta fase é gerado um analisador sintático estocástico específico para a gramática gerada nas fases anteriores.

4. Atribuição de Z-escores: Como a probabilidade de uma seqüência é o produto das probabilidades das produções utilizadas em sua derivação, seqüências que utilizem diferentes números de produções não terão probabilidades comparáveis ${ }^{14}$. Por esse motivo é necessário normalizar esses valores a fim de podermos realizar uma classificação. Essa normalização é feita através da atribuição de um escore, chamado $Z$-escore, a cada seqüência.

5. Definição de um limiar de Z-escore: Com base nos resultados obtidos, é preciso definir um valor de Z-escore que represente um limiar entre seqüências consideradas positivas (pertencentes à família modelada pela gramática) e negativas (não pertencentes à família modelada pela gramática).

A seguir é descrito como cada uma dessas etapas foi executada na geração de classificadores de TERCs.

\footnotetext{
${ }^{13}$ Neste caso, a gramática é gerada por um algoritmo de inferência gramatical a partir de uma amostra de treinamento.

${ }^{14}$ Cada vez que um valor é multiplicado por outro menor que um, o resultado final vai ficando menor.
} 


\section{Geração de gramáticas livres de contexto}

Para a caracterização de TERCs, foi utilizada a estratégia de desenho manual de uma gramática específica ao invés de inferi-la de uma amostra de treinamento. Essa escolha permite que a gramática seja desenhada de forma a respeitar uma estrutura secundária de interesse.

Para facilitar o processo de desenho da gramática, foi desenvolvido o programa scfg_generator.pl. Este programa gera, a partir de um arquivo contendo uma descrição em alto nível de um conjunto de estruturas secundárias relacionadas, uma gramática estocástica que reconheça seqüências com esta estrutura.

Cada linha deste arquivo descreve um componente de estrutura secundária. A cada componente deve ser atribuído um identificador e um tipo estrutural. O tipo pode ser, essencialmente, uma bifurcação, um loop, uma hélice ou um loop interno. No caso de uma bifurcação, é preciso informar os identificadores dos dois componentes que derivam da bifurcação. Para os demais tipos, é preciso informar o tamanho do componente (número de bases para loop ou pares de bases para hélices e loops internos) e, se existir um componente que o sucede, o identificador deste componente. Essas informações devem seguir o formato:

- para descrição de bifurcações:

<id> 2 branch <componente 1> <componente 2>

- e para descrição dos demais tipos de componentes:

$\langle$ id $\rangle \quad\langle$ tipo $\rangle \quad\langle$ tamanho $\rangle$ [<próximo componente $\rangle]$

onde [<próximo componente>] é opcional.

Na verdade, para os tipos loop, hélice e loop interno, existem tipos alternativos (loop extra, hélice extra e loop interno extra, respectivamente) que definem componentes opcionais, ou seja, que podem aparecer ou não em uma seqüência. Com esses tipos adicionais é possível definir componentes de tamanho variado. Por exemplo, as linhas

$\begin{array}{llll}\text { L1 loop } & 5 & \text { L1_extra } \\ \text { L1_extra } & \text { loop_extra } & 3 & \end{array}$

definem dois loops consecutivos: um de 5 e outro de 3 bases. O segundo, porém, descreve bases que podem ser reconhecidas ou não. A concatenação desses dois loops pode ser vista como um único 
loop cujo tamanho pode variar de 5 a 8 bases. Desta forma é possível descrever não apenas uma estrutura, mas variações dela.

\section{Descrição da estrutura consenso de TERCs de ciliados}

Para descrever uma estrutura que representasse a amostra de treinamento (TERCs de ciliados), foi contabilizado o tamanho de cada um dos componentes estruturais (hélices, loops, etc) de cada um dos 22 TERCs de ciliados ${ }^{15}$. Desta forma, os tamanhos mínimos e máximos dos componentes estruturais descritos para a geração da gramática foram estipulados de forma a englobar os tamanhos dos componentes desta amostra de treinamento.

Várias gramáticas foram geradas e testadas. O requisito mínimo exigido para essas gramáticas é que elas fossem capazes de reconhecer todas as 22 seqüências de TERCs de ciliados.

A análise sintática de gramáticas livres de contexto pode ser um processo lento, pois a complexidade de tempo é de $O\left(n^{4}\right)$ para o tipo de gramáticas aqui geradas, onde $n$ é o tamanho da seqüência. Devido a esse problema de eficiência e à maior variabilidade ao longo da hélice IV dos TERCs de ciliados, optamos por desenhar gramáticas que caracterizem apenas a primeira metade dos TERCs, ou seja, a região encerrada pelos extremos da hélice I (figura 4.7).

\section{Estimação de probabilidades da gramática}

A gramática gerada pelo scfg_generator.pl é estocástica. No entanto as produções possuem uma distribuição de probabilidade pouco informativa ${ }^{16}$. É necessário, portanto, uma reestimação dessas probabilidades a partir de uma amostra de treinamento.

Para fazer a estimação, foi utilizado o algoritmo TGR (Tree Grammar Reestimator) [230]. Ele utiliza como amostra de treinamento seqüências parentisadas em conformidade com sua estrutura secundária. Portanto, a fim de utilizar os TERCs de ciliados no processo de treinamento, cada uma das 22 seqüências ${ }^{17}$ foi parentisada.

A gramática que o algoritmo $T G R$ recebe já deve ser estocástica. Essa distribuição inicial sobre as regras gramaticais é recalculada utilizando a técnica EM (Expectation-Maximization) [10]. O algoritmo assume uma distribuição de Dirichlet [271] sobre os possíveis valores de probabilidades

\footnotetext{
${ }^{15}$ Para os TERCs com estrutura secundária publicada, utilizamos essa estrutura como base. Para as restantes nos baseamos em parte na estrutura predita pelo MFOLD e em parte na similaridade estrutural com as demais seqüências.

${ }^{16}$ Resumidamente, cada base em um loop tem a mesma probabilidade. Em cada hélice, pareamentos canônicos têm uma mesma probabilidade $P_{c}$, e pareamentos não canônicos têm uma mesma probabilidade $P_{n}$, com $P_{c}>P_{n}$.

${ }^{17}$ A parentisação de cada seqüência foi baseada na mesma estrutura utilizada para contabilização dos tamanhos dos componentes no processo de desenho da gramática.
} 


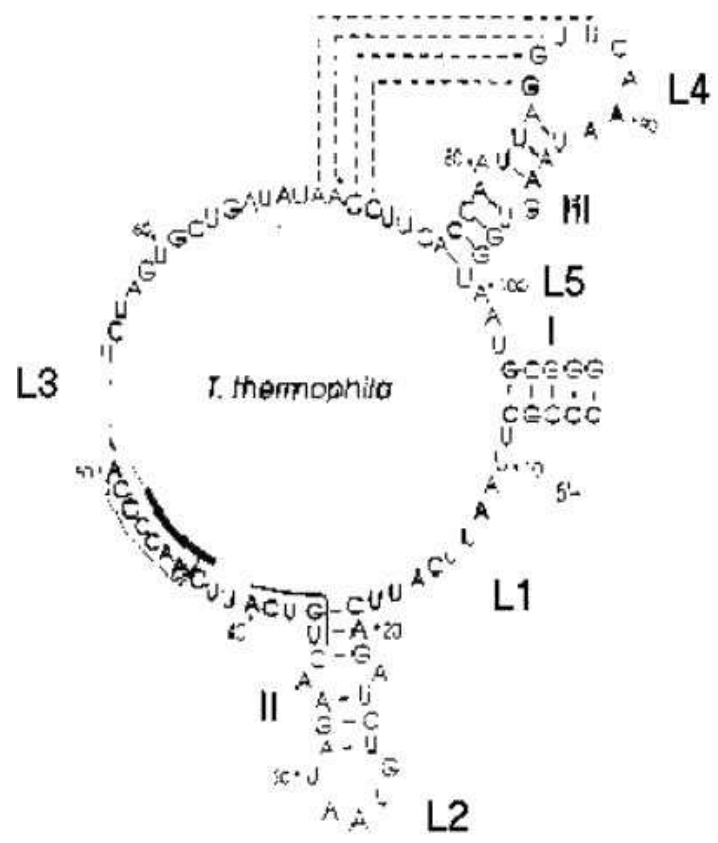

Figura 4.7: Estrutura secundária de TERC de Tetrahymena thermophila, apenas a parte definida entre o início e o fim da Hélice I. L1 a L5 indicam cinco regiões de loop. Figura editada de [158].

que serão estimados ${ }^{18}$. Esta distribuição é parametrizada por valores de escolha do implementador que podem ser interpretados como pseudo-contadores ${ }^{19}$. Nosso arcabouço foi adaptado de forma que esses parâmetros possam ser informados juntamente com a descrição da gramática. Os parâmetros utilizados foram os mesmos utilizados em [271], cujos valores foram obtidos a partir de análises de rRNAs.

${ }^{18}$ A função densidade de probabilidade de Dirichlet sobre $K$ parâmetros $\left(\theta=\left(\theta_{1}, \ldots, \theta_{K}\right)\right)$ é dada por

$$
P(\theta \mid \alpha)=M^{-1}(\alpha) \prod_{i=1}^{K} \theta_{i}^{\alpha_{i}-1} \delta\left(\sum_{i=1}^{K} \theta_{i}-1\right),
$$

onde $\alpha=\left(\alpha_{1}, \ldots, \alpha_{K}\right)$ são parâmetros da distribuição de Dirichlet, $0 \leq \theta_{i} \leq 1$ e $\delta$ é uma função indicadora que retorna 1 quando $\sum_{i=1}^{K} \theta_{i}=1$ e 0 caso contrário. $M(\alpha)$ é um fator de normalização:

$$
M(\alpha)=\int \prod_{i=1}^{K} \theta_{i}^{\alpha_{i}-1} \delta\left(\sum_{i=1}^{K} \theta_{i}-1\right) d \theta=\frac{\prod_{i} \Gamma\left(\alpha_{i}\right)}{\Gamma\left(\sum_{i} \alpha_{i}\right)}
$$

onde $\Gamma$ é a função gama: $\Gamma(x+1)=x \Gamma(x)$ [71].

${ }^{19}$ Algumas estimações são baseadas em contadores onde, resumidamente, a probabilidade de um evento é a razão entre seu contador (contagem de sua freqüência) e a soma de todos os contadores. Neste cenário, pseudo-contadores são contadores previamente inicializados com um valor diferente de zero. 


\section{Cálculo de Z-escore e escolha de limiar}

Como já mencionado, as probabilidades de seqüências que possuem diferentes números de produções em sua derivação não são comparáveis. Para normalizar esses valores, o valor do Z-escore é calculado da seguinte maneira [144]:

1. Obtém-se uma amostra positiva (potencialmente a amostra de treinamento) e uma amostra negativa.

2. Calcula-se o NLL-escore (Negative Log Likelihood score) para cada seqüência das amostras positiva e negativa. O NLL-escore de uma seqüência $s$ é calculado como ${ }^{20}$

$$
N L L(s)=-\log (L(G \mid s))
$$

onde $L(G \mid s)$ é a verossimilhança da seqüência $s$ dada pela gramática $G$.

3. Os NLL-escores de todas as seqüências são representados em um gráfico em função do número de produções utilizadas na análise sintática das seqüências.

4. Para os pontos referentes à amostra negativa, traça-se um curva que represente a média dos pontos e outra que represente o desvio padrão. Para isso, é escolhido um tamanho de uma janela deslizante que irá percorrer a abscissa. Esse tamanho é definido não pelo comprimento da janela mas pela quantidade mínima de pontos (que aqui representam seqüências) que ela deve conter ${ }^{21}$. Em cada janela, é calculado o ponto que representa a média dos números de produção e dos escores NLL dos pontos internos a essa janela. Da mesma forma é calculado o ponto que representa o desvio padrão desses valores. Uma curva é interpolada (linearmente) sobre os pontos médios, e outra sobre os pontos de desvios. As extremidades são extrapoladas (linearmente) (figura 4.8). Essas curvas definem duas funções, $N L L_{m e d}$ e $N L L_{d p}$. A função $N L L_{\text {med }}$ é o NLL médio de seqüências negativas em função do número de produções, e a função $N L L_{d p}$ é o desvio padrão de NLL's de seqüências negativas em função do número de produções.

5. Calcula-se o Z-escore de cada seqüência $s$ (positiva e negativa) como

$$
Z(s)=\frac{N L L(s)-N L L_{m e d}\left(n_{s}\right)}{N L L_{d p}\left(n_{s}\right)}
$$

\footnotetext{
${ }^{20}$ Como a probabilidade de uma seqüência tende a ficar um número muito pequeno, esse valor pode ultrapassar a precisão do computador. Trabalhar com o log negativo é uma forma de lidar com números maiores e positivos.

${ }^{21}$ Por exemplo, uma janela de tamanho 40 que tem início na posição $i$ terá seu fim na posição $j$ se dentro do intervalo $[i ; j]$ há pelo menos 40 pontos e dentro do intervalo $[i ; j-1]$ há menos de 40 pontos.
} 


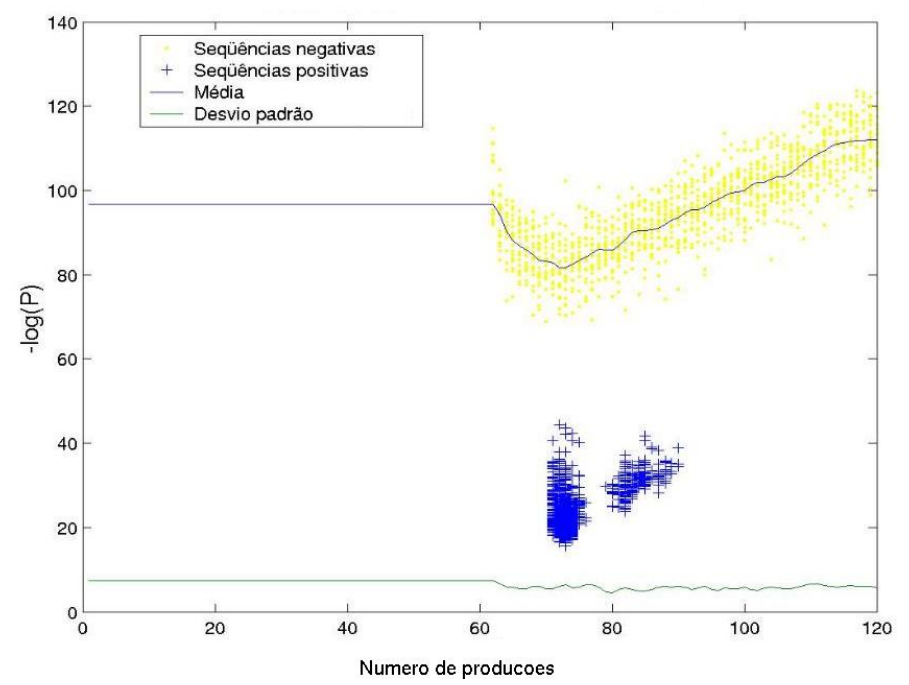

Figura 4.8: NLL escores de seqüências positivas e negativas e curvas $N L L_{m e d}$ e $N L L_{d p}$.

onde $n_{s}$ é o número de produções utilizadas na análise sintática da seqüência $s$. Isto é, o $Z$-escore é a diferença entre o $N L L$ de $s$ e o $N L L$ médio da amostra negativa no ponto $n_{s}$, medido em unidades de desvio padrão (da amostra negativa) no ponto $n_{s}{ }^{22}$.

6. Constrói-se um histograma com os Z-escores das seqüências positivas e negativas. Finalmente escolhe-se um valor limiar de Z-escore que separe as duas amostras. O ideal é que esse limiar consiga separar completamente as duas amostras. No entanto, nem sempre isso é possível.

O cálculo de Z-escore aplicado em [231] para modelagem de tRNAs utilizando GLCEs utiliza o tamanho das seqüências ao invés do número de produções nos passos 3 a 5 descritos acima. No entanto, acreditamos que essa estratégia é inadequada. Um dos fatores que faz com que as probabilidades de duas sequiências não sejam comparáveis é que, cada vez que uma produção é aplicada, há um fator a mais, com valor menor que um, a ser multiplicado no cálculo da probabilidade final da seqüência. Portanto, uma normalização pelo número desses fatores seria um procedimento apropriado. No entanto, o tamanho de uma seqüência não é necessariamente igual ao número de produções utilizadas no seu reconhecimento, principalmente no caso da maioria das GLCEs descritas para RNAs onde parte das produções reconhecem dois símbolos de uma só vez. Por esse motivo, utilizamos o número de produções, por ser esse o número exato de fatores do produto a serem

\footnotetext{
${ }^{22}$ Note que quanto mais negativo for o Z-escore, mais significativo ele será. Isso porque, como seqüências com maior probabilidade terão NLL menor, seqüências mais prováveis que seqüências negativas tenderão a apresentar o valor de $N L L(s)-N L L_{m e d}\left(n_{s}\right)$ negativo.
} 
utilizados no cálculo de probabilidade.

\section{Validação dos algoritmos utilizando tRNAs}

A fim de validar nossas implementações, o classificador foi testado dentro do domínio de seqüências de tRNAs. Como já havia um trabalho similar aplicado a tRNAs [230], a intenção era reproduzir os dados obtidos por esse grupo. Neste citado trabalho, Sakakibara e colaboradores desenharam uma gramática de tRNAs e utilizaram 1477 seqüências de tRNAs (500 como treinamento e 977 como teste) e 2016 seqüências negativas (mRNAs, rRNAs e seqüências codificantes) obtidas do Genbank para realizar vários testes.

Obtivemos a gramática de tRNAs desenhada por eles, as seqüências de tRNAs e as seqüências negativas $^{23}$. No entanto, as seqüências de tRNAs não eram parentisadas como o programa estimador de probabilidades aqui utilizado (TGR) espera. Parentisar manualmente 500 seqüências de treinamento é inviável. Portanto foi implementada uma versão expandida do algoritmo TGR descrita em [229] que aceita seqüências não parentisadas.

Os testes foram realizados inicialmente utilizando 500 seqüências de treinamento, como em [231]. Para testar o comportamento do estimador de probabilidades com amostras menores, outros testes foram realizados utilizando amostras de treinamento de tamanhos 250, 125, 62, 31, 25, 20, 18, 15, 10, 7, 5, 3, 2 e 1 . Além disso, foi testado um caso mais similar ao de TERCs: 22 tRNAs foram parentisados e o estimador foi executado em sua versão simples (utilizando diretamente seqüências parentisadas). Foi também testada a gramática sem treinamento de probabilidade, utilizando apenas uma distribuição pouco informativa citada anteriormente.

\section{Validação cruzada utilizando TERCs de ciliados}

As espécies dos 22 TERCs de ciliados pertencem a 7 diferentes filos. Cada filo possui, de forma geral, seqüências de TERCs mais similares entre si do que entre TERCs fora do filo. A fim de testar a gramática desenhada para TERCs e o processo de classificação utilizando esta gramática, foi utilizada uma estratégia de validação cruzada de filos. Para cada filo, seus TERCs foram removidos da amostra de treinamento e foram utilizados como amostra de teste.

\section{Aplicação em Plasmodium falciparum}

Foi utilizada como amostra positiva as seqüências dos 22 TERCs de ciliados. Para utilizá-las no modelo aqui desenhado, foi extraída de cada uma apenas a subseqüência delimitada pelo início

\footnotetext{
${ }^{23}$ A gramática está descrita em [231], as seqüências de tRNAs podem ser obtidas do servidor ftp da UCSC (University of California Santa Cruz), e as seqüências negativas foram gentilmente enviadas por Sakakibara e colaboradores.
} 
e fim da hélice I.

Os candidatos a TERCs obtidos no início da análise heurística foram processados de forma a serem obtidas subseqüências que apresentem uma hélice formada pelas bases iniciais e finais desta subseqüência, uma vez que a gramática foi desenhada para caracterizar subseqüências de TERCs que sejam limitadas pela hélice I. Essas possíveis hélices foram identificadas através de alinhamentos da seqüência com sua complementar utilizando o programa cross_match.

A amostra negativa foi composta de seqüências de ciliados (não TERCs) extraídas do NCBI [191] e $200 \mathrm{Mb}$ de seqüências simuladas. As seqüências simuladas são formadas por dois conjuntos: 140 $\mathrm{Mb}$ de seqüências $65 \%$ AT-rich e $60 \mathrm{Mb}$ de seqüências $85 \% \mathrm{AT}_{\text {-rich }}{ }^{24}$. Sobre esse conjunto de dados foi utilizado o mesmo método de extração de seqüências que sejam delimitadas por possíveis hélices. Essas seqüências compuseram nossa amostra negativa final.

\subsubsection{Resultados}

\section{Validação dos algoritmos utilizando tRNAs}

O resultado esperado de cada teste aqui realizado é que seja possível escolher um limiar de Zescore que permita separar completamente a amostra positiva e a amostra negativa, e que tal limiar classifique corretamente as seqüências de teste. Em todos os experimentos foi possível encontrar um bom separador para as seqüência de tRNAs e não-tRNAs. Com exceção do experimento onde não foi executada a estimação de probabilidade da gramática, esse limiar também foi capaz de reconhecer todas as seqüências tRNAs de teste.

A seguir são mostrados os gráficos de alguns dos experimentos realizados. A figura 4.9 refere-se ao teste utilizando 500 seqüências, a figura 4.10 refere-se ao teste sem treinamento e a figura 4.11 refere-se ao teste realizado com 22 seqüências parentisadas. No teste utilizando 500 seqüências, a utilização de um limiar de Z-escore de -4 classifica as seqüências de forma que a amostra positiva de treinamento e de teste tenham 0 falsos negativos e que a amostra negativa tenha 0 falsos positivos. No teste utilizando a gramática sem treinamento, esse mesmo limiar de -4 faz com que a amostra negativa seja classificada com 0 falsos positivos, porém a amostra de teste é classificada com $5.1 \%$ de falsos negativos. A utilização de 22 seqüências parentisadas no treinamento é capaz de melhorar os resultados mesmo utilizando o limiar de -4 utilizado no teste sem treinamento: a amostra de teste é classificada com $1.3 \%$ de falsos negativos, mas com 4 falsos negativos na amostra positiva de

\footnotetext{
${ }^{24}$ Esses valores procuram simular o tamanho e conteúdo AT estimados de ciliados como o Paramecium e Tetrahymena. O tamanho estimado do genoma desses organismos é $200 \mathrm{Mb}$, onde $70 \%$ (140 Mb) seria $65 \%$ AT-rich e $30 \%$ $(60 \mathrm{Mb})$ seria $85 \%$ AT-rich [250].
} 

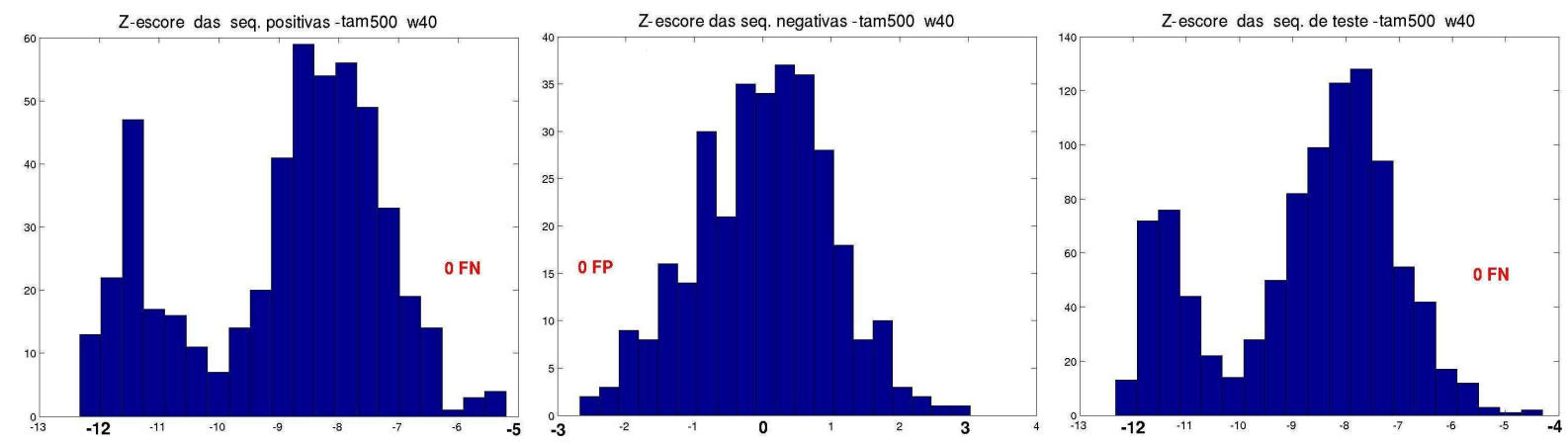

Figura 4.9: Gráfico de z-escore de tRNAs para amostra de treinamento de tamanho 500. À esquerda: amostra positiva; no centro: amostra negativa; à direita: amostra de teste.
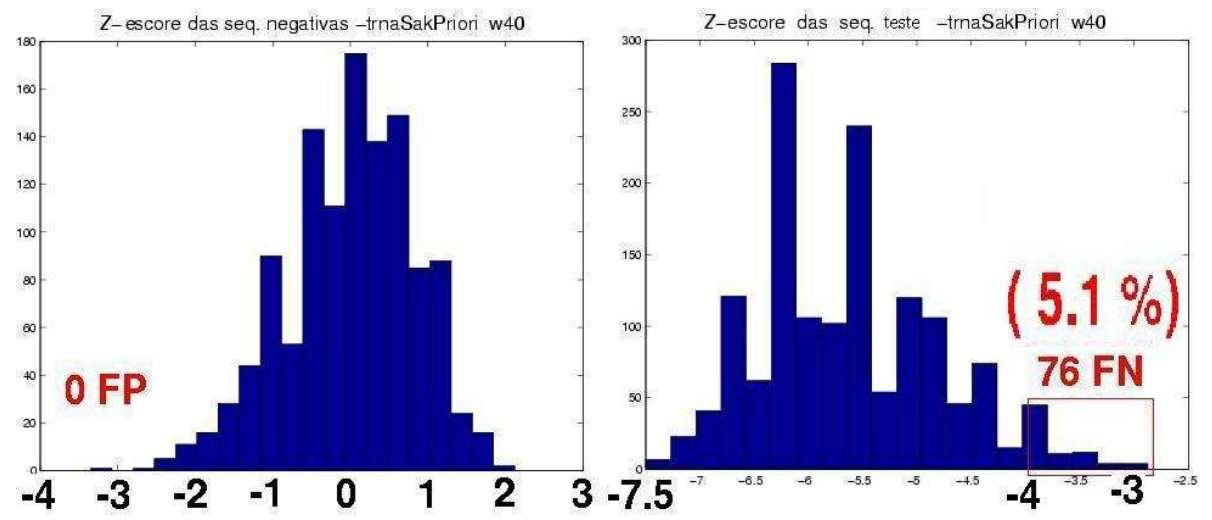

Figura 4.10: Gráfico de z-escore de tRNAs sem uso de amostra de treinamento. À esquerda: amostra negativa; à direita: amostra de teste.

treinamento. Se um limiar de -3 fosse utilizado, os resultados seriam ainda melhores. Isso mostra que o treinamento de probabilidades mesmo com poucas seqüências podem melhorar a qualidade da gramática.

\section{Validação cruzada utilizando TERCs de ciliados}

Dos 7 testes utilizando cada um dos 7 filos como amostra de teste, 3 apresentaram bons resultados que permitiram a escolha de um limiar de Z-escore adequado. Um exemplo é o teste para o filo Colpidium, cujos resultados são apresentados na figura 4.12. Os 4 demais testes, no entanto, não apresentaram o mesmo sucesso. Mesmo quando era possível escolher um limiar de Z-escore que separava a amostra positiva de treinamento e a negativa, tal limiar não reconhecia a amostra de teste 

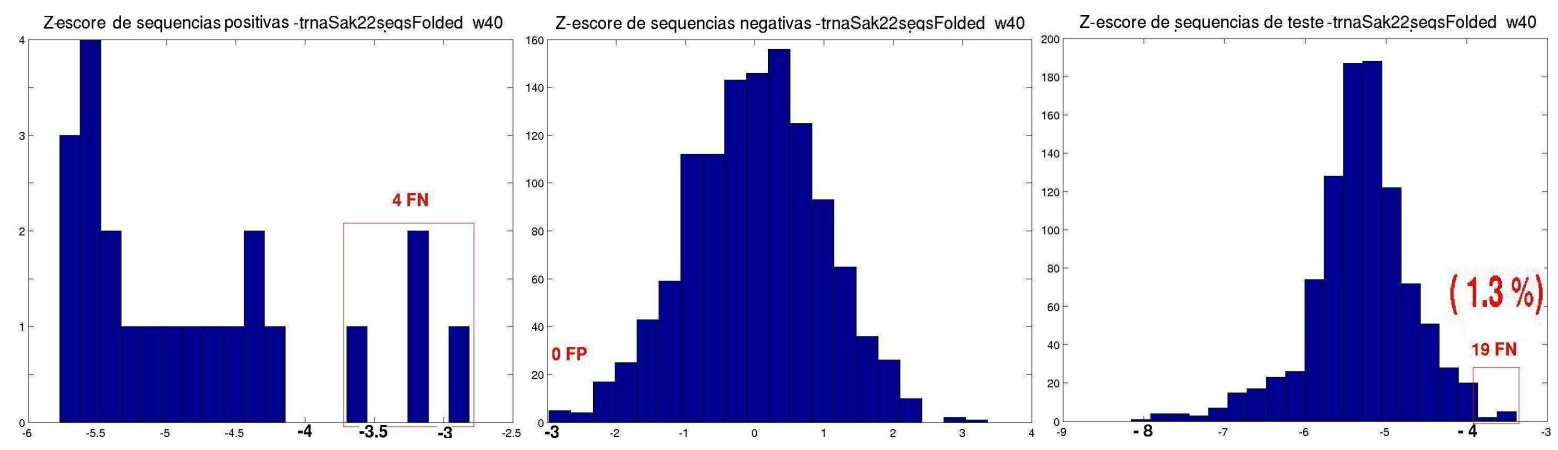

Figura 4.11: Gráfico de z-escore de tRNAs para amostra de treinamento parentisada de tamanho 22. À esquerda: amostra positiva; no centro: amostra negativa; à direita: amostra de teste.

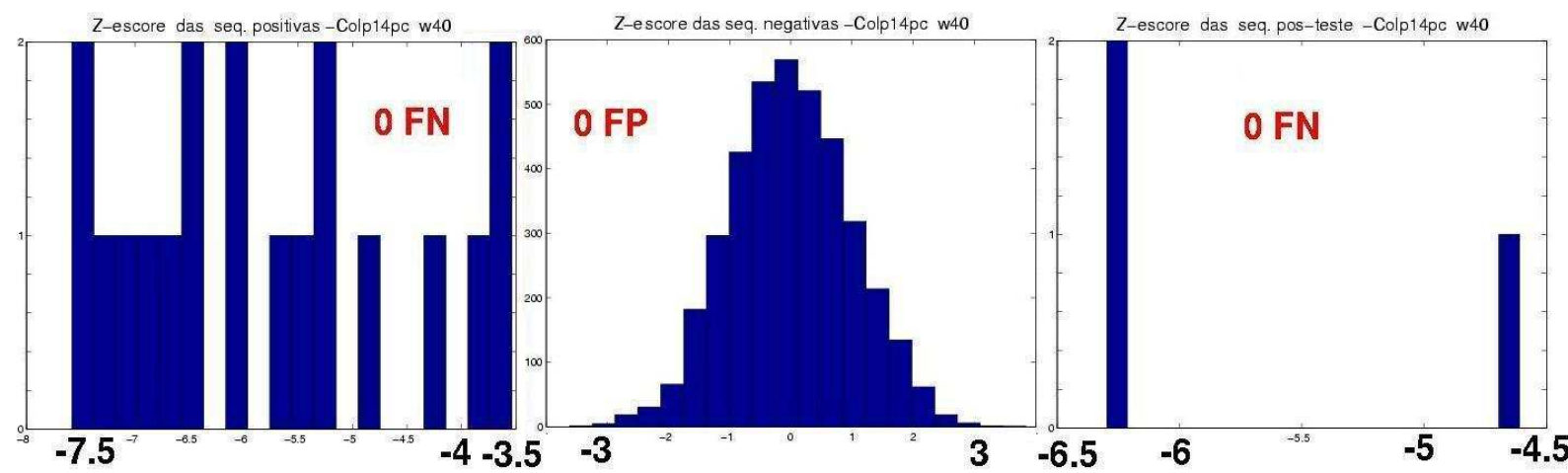

Figura 4.12: Gráfico de z-escore de validação cruzada de TERCs deixando TERCs de Colpidium como amostra de teste. Um limiar de Z-escore $=-3.5$ faz com que a amostra positiva de treinamento tenha 0 falsos negativos, a amostra negativa tenha 0 falsos negativos e que a amostra positiva de teste tenha 0 falsos positivos.

como sendo TERCs, caracterizando uma alta taxa de falsos negativos. O teste do filo Paramecium é um exemplo, cujos resultados são apresentados na figura 4.13 .

\section{Aplicação em Plasmodium falciparum}

Foram realizados apenas alguns testes preliminares com os candidatos de Plasmodium falciparum. Nestes testes nenhum candidato se sobressaiu. Na verdade, não foi nem mesmo possível obter um bom separador entre as seqüências positivas e negativas. 


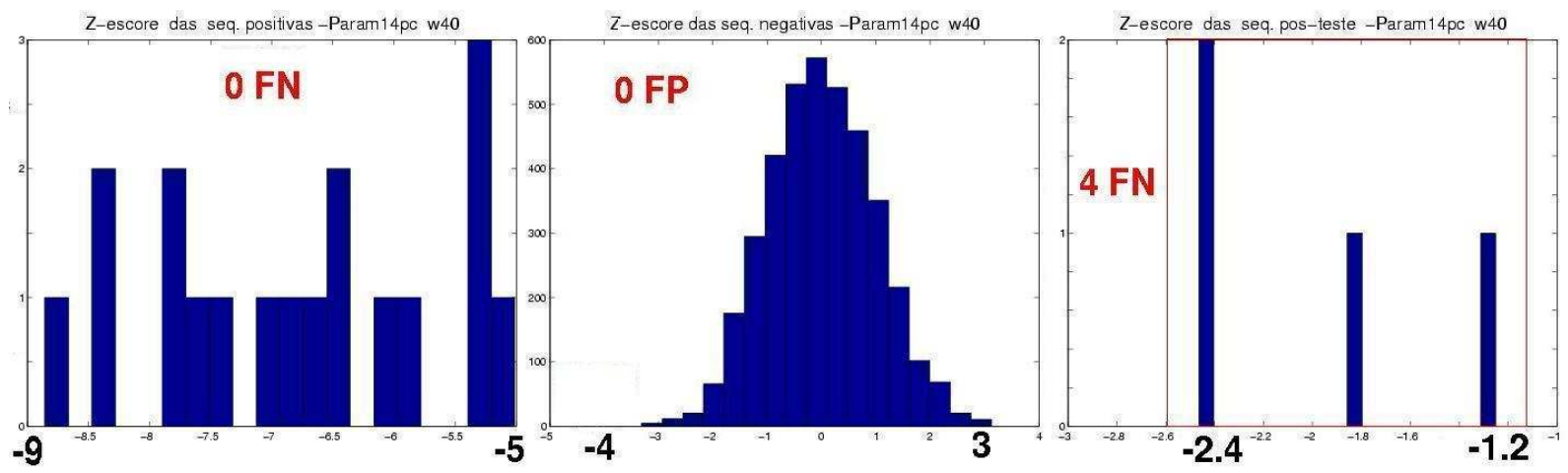

Figura 4.13: Gráfico de z-escore de validação cruzada de TERCs deixando TERCs de Paramecium como amostra de teste. Um limiar de Z-escore $=-4$ faz com que a amostra positiva de treinamento tenha 0 falsos negativos, a amostra negativa tenha 0 falsos negativos e que a amostra positiva de teste tenha 4 falsos positivos (100\%). 



\section{O sistema TERP de predição de TERCs}

Conforme discutido no capítulo 4, optamos pela utilização de gramáticas livres de contexto estocásticas na modelagem de TERCs pela sua capacidade de caracterizar seqüências de RNAs e suas estruturas secundárias. A utilização direta do INFERNAL [76], ferramenta referência na identificação de ncRNAs baseada em uma abordagem gramatical, não produziu resultados satisfatórios em P. falciparum. As regras gramaticais inferidas pelo INFERNAL permitem que qualquer seqüência seja reconhecida pelo analisador sintático, mesmo que a amostra de treinamento seja $100 \%$ conservada. Uma seqüência é então classificada por seu escore. Para que qualquer seqüência seja reconhecida, as regras gramaticais possuem um grande número de parâmetros que precisam ser estimados a partir da amostra de treinamento, o que pode ser um problema quando a amostra de treinamento é pequena. Essas regras são geradas automaticamente, não permitindo a criação de regras gramaticais específicas para regiões altamente conservadas como, por exemplo, o template telomérico de TERCs. Por esse motivo, nossa abordagem inicial foi direcionada no sentido de desenhar gramáticas manualmente, de forma a serem o mais enxutas possível. Infelizmente, os bons resultados na caracterização de tRNAs não se repetiram para TERCs. A detecção de problemas como a sobre-representação de sequiências similares e a rápida divergência entre TERCs de espécies mais distantes filogeneticamente revelou que era necessária uma abordagem intermediária: a capacidade de generalização do INFERNAL com algum controle na inferência das regras gramaticais.

INFERNAL $[76,80]$ foi escolhido para ser a base do sistema desenvolvido neste trabalho por possuir um conjunto de características não encontrado nos demais programas:

- INFERNAL é um pacote de programas que cria um modelo tanto da seqüência primária quanto da estrutura secundária a partir de uma amostra de treinamento, e busca seqüências homólogas fazendo uso eficiente de memória.

- O modelo criado é uma gramática livre de contexto estocástica [244], uma tecnologia que já vínhamos estudando $[135,170]$ e que tem mostrado resultados promissores na caracterização 
de seqüências biológicas [68, 229, 227, 243, 245].

- INFERNAL é probabilístico e bayesiano. Sendo probabilístico, permite que as distribuições por ele usadas sejam ajustadas conforme a realidade do problema sendo tratado. Sendo bayesiano, tem um poder maior de generalização, evitando overfitting, e seu sistema de escore pode ser visto como um resultado de classificação bayesiana (como discutido a seguir neste capítulo).

- Para evitar sobre-representação de seqüências muitos similares na amostra de treinamento, INFERNAL atribui pesos às seqüências de treinamento de acordo com seu grau de divergência. Essa característica é especialmente relevante no caso de TERCs, uma vez que há sub-grupos de seqüências muito similares devido à presença de TERCs de espécies muito próximas filogeneticamente.

- INFERNAL permite a realização de ajustes no sistema de escore considerando o problema de genomas com viés composicional. A classificação bayesiana realizada pelo INFERNAL considera dois modelos: o da família de seqüências representada pela amostra de treinamento e outro, chamado nulo, que caracteriza o universo complementar, ou seja, o das seqüências não pertencentes à família representada pela amostra de treinamento. Esse modelo nulo, como discutido a seguir, é o alvo apropriado dos ajustes de composição de bases.

- Queremos inserir conhecimento a priori modelando regiões da seqüência primária que são sabidamente conservadas como, no exemplo de TERCs, o template e sua extensão. Para isso, um trecho do modelo estimado deve ser alterado. O modelo estimado pelo INFERNAL é armazenado em um arquivo texto, permitindo fácil alteração antes de seu uso na busca por candidatos.

- INFERNAL é um pacote de código livre, o que permite a realização de alterações necessárias no código fonte.

- Finalmente, INFERNAL é uma ferramenta referência na identificação de RNAs não codificantes, sendo utilizado em diversos trabalhos [101, 162, 204, 212]. Desta forma, nossas contribuições se tornam mais efetivas para a comunidade científica.

Nesta direção, foi desenvolvido o sistema TERP (TElomerase RNA Predictor) para predição de candidatos a TERC em um genoma. No entanto, este sistema pode também ser aplicado na identificação de outras famílias de RNAs (capítulo 6).

Para ganhar maior sensibilidade e especificidade, o sistema utiliza conhecimento a priori sobre TERCs através de uma modelagem específica para a região do template e sua extensão, forçando 
seu reconhecimento. Ele inicialmente faz uma seleção de pré-candidatos, analisa-os de acordo com um modelo de TERCs, e fornece uma lista de candidatos ordenada pela significância do escore do candidato. Tudo isso é feito de forma automática, deixando ao usuário a tarefa de apenas escolher um conjunto de parâmetros como, por exemplo, o genoma a ser aplicado e a seqüência de seu template telomérico.

A seleção de pré-candidatos visa diminuir o tempo de execução e permitir o cálculo de modelos nulos específicos (como discutido adiante). Para modelar TERCs, o sistema utiliza modelos de covariância [80], que são modelos equivalentes a uma categoria de gramáticas livres de contexto estocásticas [246]. A construção desses modelos e a análise dos pré-candidatos de acordo com esses modelos são realizadas utilizando o pacote INFERNAL [76]. Os modelos são customizados pelo TERP tanto para inserir características de TERCs quanto para ajustar o sistema de escore de forma que um provável viés composicional no genoma sendo analisado não distorça os resultados de classificação. Esses ajustes do sistema de escore estão relacionados com uma escolha adequada do modelo nulo. Essa escolha exige cuidado especial, e por isso é tratada em uma seção específica (seção 5.2). Finalmente, o teste de significância dos escores fornece uma medida mais realista para ser utilizada na ordenação dos candidatos a TERCs. Devido à taxa de mutação dos TERCs, é possível que o TERC apresente um escore baixo, se confundindo com o ruído das outras seqüências. Por isso uma classificação baseada simplesmente no escore dado pelo modelo de covariância pode perder sensitividade e especificidade. A finalidade da significância do escore é colocar o verdadeiro TERC acima do ruído, tanto quanto possível.

Para compreender o sistema TERP, é necessário conhecer um pouco do INFERNAL, especialmente os pontos onde customizações são feitas pelo TERP. Por isso, a seção 5.1 descreve características do INFERNAL relevantes para o TERP. A seção 5.2 traz um estudo para a escolha de um modelo nulo apropriado, que irá permitir uma análise mais precisa mesmo em genomas com viés composicional. A seção 5.3 descreve o sistema TERP e os métodos utilizados nos testes do sistema e nas aplicações em espécies sem TERC conhecida. Finalmente, a seção 5.4 apresenta os resultados dos testes e das aplicações.

\subsection{INFERNAL}

INFERNAL é um pacote de programas que permite a construção de modelos probabilísticos para representar uma família de RNAs (programa cmbuild), o uso desses modelos para buscar seqüências de RNAs homólogos em bancos de dados ou genomas (programa cmsearch) e a criação de novos alinhamentos estruturais (programa cmalign) [122]. 


\subsubsection{Modelos de Covariância}

Modelos de covariância são modelos probabilísticos que caracterizam tanto a seqüência quanto a estrutura secundária de um conjunto de RNAs. Eles são criados a partir de um alinhamento estrutural no qual haja a anotação da estrutura secundária relativa a cada coluna (figura 5.1).

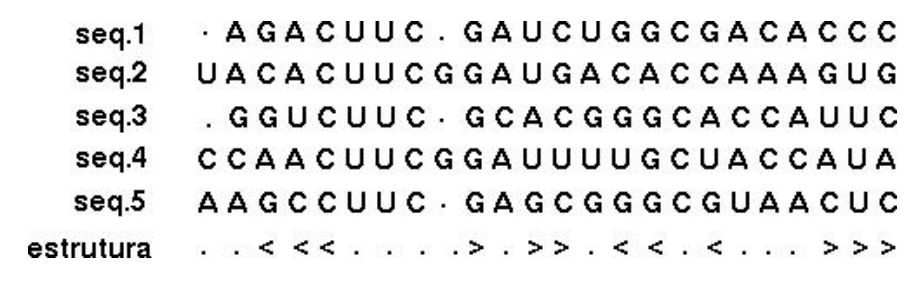

Figura 5.1: Alinhamento múltiplo estrutural: o alinhamento é obtido considerando não apenas a seqüência primária como também a estrutura secundária. A última linha representa a estrutura secundária relativa a cada coluna, onde "." representa posições não pareadas e " $<$ " e "> pareados representam um par de posições pareadas. Figura adaptada de $[71]$.

O modelo de covariância é composto por estados, símbolos de emissão, probabilidades de transição entre os estados e probabilidades de emissão de símbolos em cada estado. Os símbolos de emissão representam os nucleotídeos: A, C, G e T (ou U). Os estados são utilizados para representar a estrutura secundária. Cada tipo de estado representa uma característica de estrutura secundária. Os principais tipos são:

- $P$ (pair) para representar pares de colunas que estejam pareadas na estrutura secundária;

- $R$ (rightwise) para representar bojos e loops internos do lado direito (3') de uma hélice;

- L (leftwise) para representar bojos e loops internos do lado esquerdo (5’) de uma hélice e demais colunas não pareadas;

- $B$ (bifurcation) para representar bifurcações da estrutura em múltiplas hélices;

- S (start) para representar início da estrutura completa e de sub-estruturas (após bifurcações);

- $E$ (end) para representar o fim de uma estrutura ou sub-estrutura.

Estados $P$ emitem um par de símbolos, e por isso possuem uma distribuição de probabilidades para 16 possíveis emissões, ou seja, todos os possíveis pares de 4 nucleotídeos. Estados $R$ e $L$ emitem apenas um símbolo, e por isso possuem uma distribuição de probabilidades para 4 possíveis emissões. Estados $B, S$ e $E$ não emitem símbolos. 
Para exemplificar a construção de um modelo de covariância, considere o alinhamento da figura 5.2A. O primeiro passo consiste em definir a estrutura consenso desse alinhamento. Essa estrutura é definida pela anotação estrutural presente no alinhamento desconsiderando colunas com número de gaps superior a 50\% (parâmetro ajustável). A figura 5.2B mostra a estrutura e a seqüência ${ }^{1}$ consenso deste alinhamento.
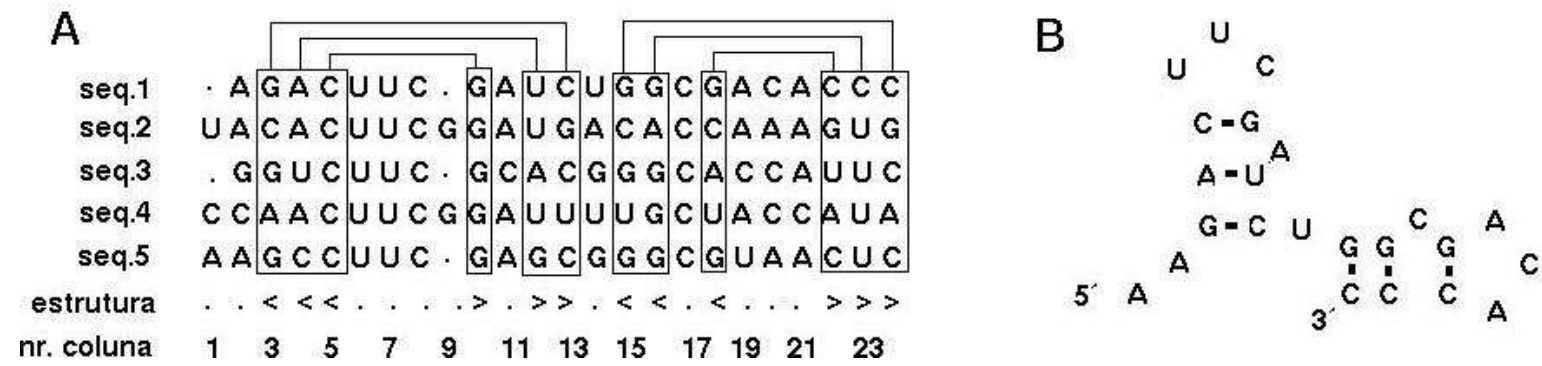

Figura 5.2: A: Alinhamento múltiplo estrutural: as caixas indicam as colunas pareadas formando hélices. B: Estrutura consenso obtida do alinhamento da figura A. Colunas com número de gaps superior a $50 \%$ do número de seqüências não participam da estrutura consenso. Figura adaptada de [71].

Essa estrutura é então representada através de uma árvore dos estados do modelo de covariância, como mostra a figura 5.3. Nesta figura, os estados são representados por retângulos rotulados pelo seu tipo. Triângulos ao lado dos retângulos indicam o sentido (5' ou 3') da emissão de símbolos. A numeração ao lado dos triângulos indica o(s) número(s) da(s) coluna(s) correspondente(s) à emissão.

Uma vez que a estrutura consenso esteja representada através dessa árvore guia, é necessário adaptar esse modelo para o reconhecimento de seqüências que possuam inserções e deleções em relação a essa estrutura. Por exemplo, nucleotídeos em colunas que não participaram da estrutura consenso por possuírem muitos gaps (coluna 9 na figura 5.2A) são considerados inserções. Da mesma forma, gaps em colunas consideradas parte da estrutura consenso (coluna 1 na figura 5.2A) são considerados deleções. Para representar esses eventos são necessários três novos estados: $I L$ para inserção à esquerda, $I R$ para inserção à direita e $D$ para deleção.

Inserções e deleções também podem ocorrer em colunas pareadas. Para representar deleção de apenas um nucleotídeo de um par, os estados $L$ e $R$ são utilizados. O estado $L$ é utilizado quando ocorre apenas o nucleotídeo do lado esquerdo do par (deleção do lado direito) e o estado $R$ é utilizado quando ocorre apenas o nucleotídeo do lado direito do par (deleção do lado esquerdo). O estado $D$ é utilizado quando há deleção do par inteiro.

A estrutura de um modelo de covariância completo é capaz de reconhecer inserções e deleções

\footnotetext{
${ }^{1}$ Apenas a estrutura consenso, e não a seqüência, é utilizada para a construção do modelo de covariância. No entanto a seqüência consenso é apresentada na figura 5.2B para facilitar a visualização da estrutura consenso em relação ao alinhamento.
} 


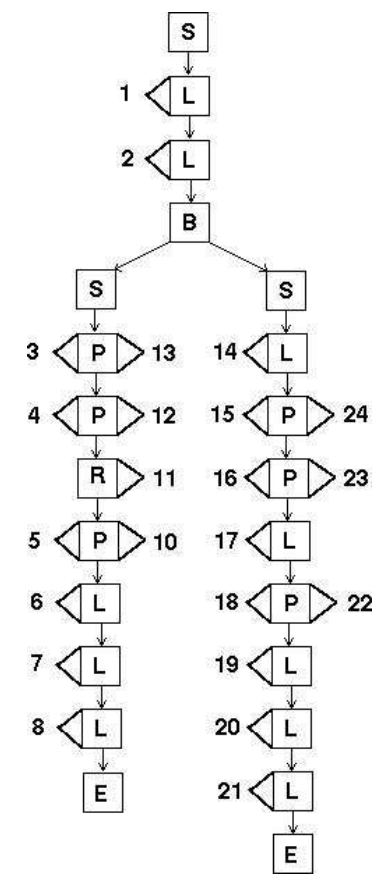

Figura 5.3: Árvore guia do modelo de covariância obtido a partir da estrutura consenso. Estados são representados por retângulos rotulados pelo seu tipo. Triângulos ao lado dos retângulos indicam o sentido (5' ou 3') da emissão de símbolos. A numeração ao lado dos triângulos indica o(s) número(s) da(s) coluna(s) correspondente(s) à emissão, indicadas na figura 5.2. Figura adaptada de [71].

em todas as posições da estrutura consenso. Para isso, cada estado da árvore guia (figura 5.3) é substituído por um conjunto de estados que permitam inserções e deleções. As substituições são realizadas de acordo com a tabela 5.1 (estados não mencionados na tabela não são substituídos).

A figura 5.4 mostra como fica a arquitetura completa de parte da árvore guia (flechas indicando transições permitidas).

As probabilidades de emissão e de transição de cada estado são estimadas a partir do mesmo alinhamento utilizado para construir a arquitetura do modelo covariância. A estimação é feita por máxima a posteriori, utilizando como priori uma mistura de distribuições de Dirichlet [76].

\subsubsection{Sistema de escore}

Dada uma seqüência $x$ qualquer, há vários caminhos $\pi$ passando pelas transições de estados de um modelo de covariância $M$ que são capazes de reconhecer a seqüência $x$. A probabilidade de $x$ em cada caminho deste modelo $(P(x \mid \pi, M))$ é o produto das probabilidades de transições entre os estados nesse caminho e as probabilidades das emissões nesses estados necessárias para reconhecer $x$. O melhor caminho para $x$ é aquele que atribui a mais alta probabilidade a $P(x \mid \pi, M)$, representando 
Estado na árvore guia

$P$

$L$

$R$

$S$ no início da estrutura

$S$ no lado direito de uma bifurcação
Conjunto de estados no modelo de covariância final

$P, L, R, D, I L$ e $I R$

$L, D$ e $I L$

$R, D$ e $I R$

$S, I L$ e $I R$

$S$ e $I L$

Tabela 5.1: Tabela de substituição de cada estado representado na árvore guia (coluna 1) por um conjunto de estados (coluna 2) no modelo de covariância final. Estados não mencionados na tabela não são substituídos.

o alinhamento mais provável da seqüência $x$ ao modelo de covariância $M$.

A probabilidade de uma seqüência $x$ dado o melhor caminho e um modelo de covariância $M$, por si só, não é muito esclarecedora para decidir se $x$ é uma seqüência homóloga às seqüências utilizadas para construir $M$ ou não. Por exemplo, seqüências maiores tendem a possuir uma probabilidade menor, pois um número maior de transições e emissões são necessárias para reconhecê-las, o que implica maior número de fatores menores que 1 no produto final de cálculo da probabilidade.

Para classificar uma seqüência como homóloga ou não, INFERNAL utiliza classificação bayesiana, que classifica uma seqüência como pertencente ao modelo de maior probabilidade dada a seqüência. Para isso, utiliza o cálculo de escore $\log$-odd, onde apenas dois modelos são considerados: $M$ e $N$. $M$ é o modelo de covariância, que representa a alternativa de $x$ ser homóloga. $N$ é o modelo nulo, que representa a alternativa de $x$ não ser homóloga. A classificação da seqüência $x$ dependerá de qual modelo tiver maior probabilidade dado $x(P(M \mid x)$ ou $P(N \mid x)$, onde $P(M \mid x)+P(N \mid x)=1)$. Ou seja, $x$ é classificada como homóloga se $P(M \mid x)>0.5$.

$P(M \mid x)$ pode ser calculada como:

$$
\begin{gathered}
P(M \mid x)=\frac{P(x \mid M) P(M)}{P(x \mid M) P(M)+P(x \mid N) P(N)} \\
=\frac{P(x \mid M) P(M) / P(x \mid N) P(N)}{P(x \mid M) P(M) / P(x \mid N) P(N)+1}
\end{gathered}
$$

Se $M$ e $N$ são considerados equiprováveis, isto é, $P(M)=P(N)$, então

$$
P(M \mid x)=\frac{P(x \mid M) / P(x \mid N)}{P(x \mid M) / P(x \mid N)+1}
$$

INFERNAL utiliza a probabilidade de $x$ dado o melhor caminho no modelo de covariância $M$ como sendo $P(x \mid M) . P(x \mid N)$ é dada pela probabilidade de $x$ dada uma distribuição posição-independente 


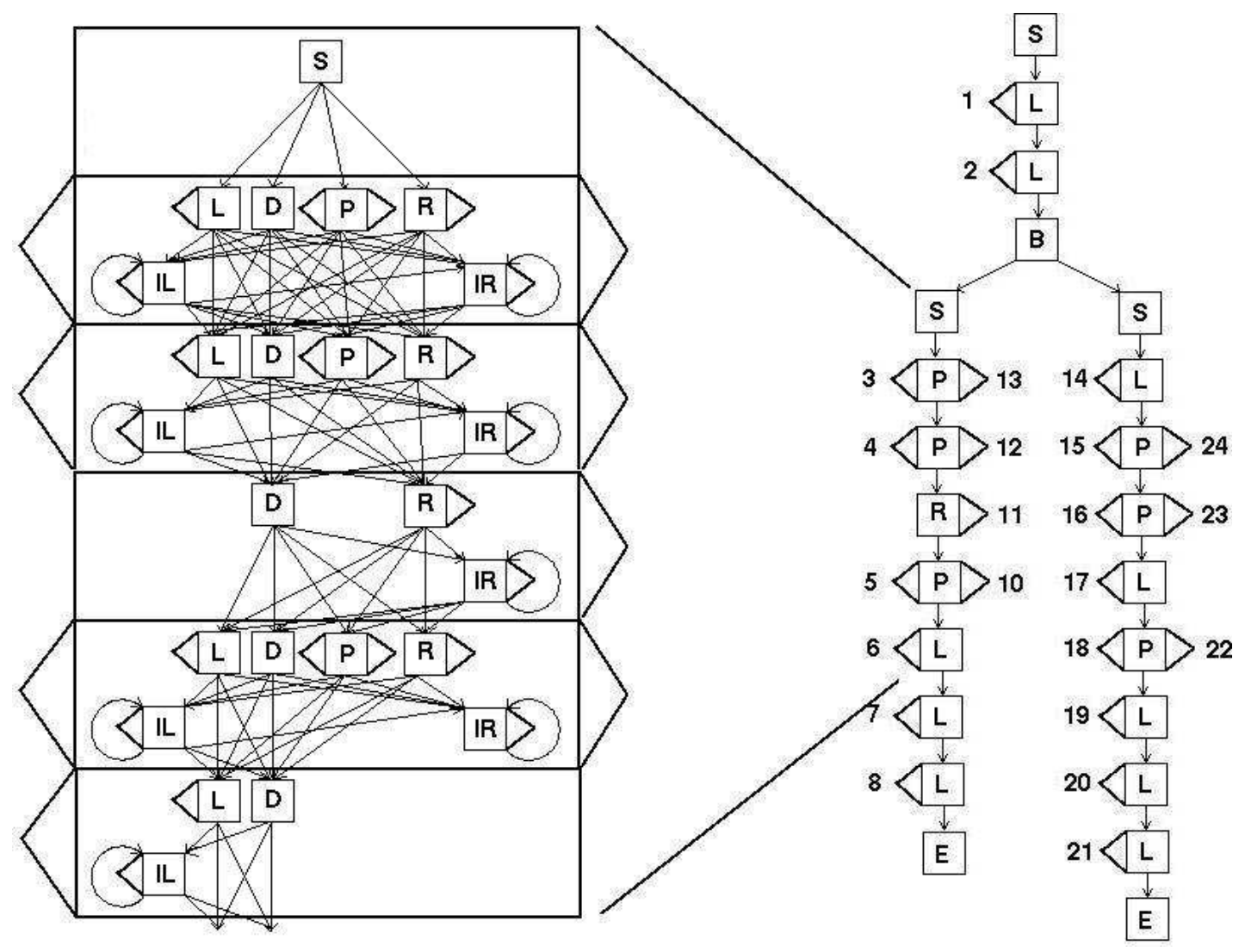

Figura 5.4: Arquitetura completa do modelo de covariância relativo ao trecho destacado da árvore guia (estrutura consenso). Cada estado na árvore guia foi substituído por um conjunto de estados de forma a permitir a identificação de inserções e deleções.

dos nucleotídeos, isto é, $P(x \mid N)=n_{A} P_{N}(A) * n_{C} P_{N}(C) * n_{G} P_{N}(G) * n_{T} P_{N}(T)$, onde $n_{B}$ é o número de vezes que o nucleotídeo $B$ ocorre na seqüência $x$, e $P_{N}(B)$ é a probabilidade do nucleotídeo $B$ segundo essa distribuição do modelo $N$.

Ao definir uma variável $S$ como $S=\log \left(\frac{P(x \mid M)}{P(x \mid N)}\right)$, a equação (5.1) pode ser escrita como

$$
P(M \mid x)=\rho(S)
$$

onde

$$
\rho(S)=\frac{e^{S}}{e^{S}+1}
$$

$\rho(S)$ é conhecida como função logística (figura 5.5). Esta função tem a propriedade de tender a zero quando $S$ tende a menos infinito e a 1 quando $S$ tende a mais infinito. Além disso, assume valor 0.5 quando $S=0$. Essas propriedades fazem com que $S$ possa ser utilizado em uma classificação 
bayesiana de $x$ : se $S$ é positivo a seqüência $x$ é classificada como homóloga $(P(M \mid x)>0.5)$, caso contrário $x$ é classificada como não homóloga.

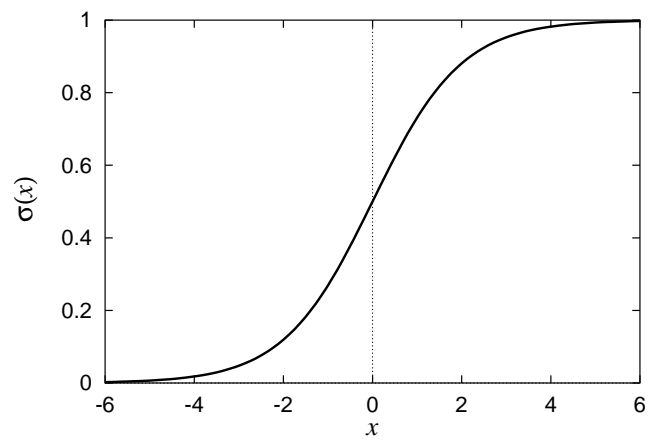

Figura 5.5: A função logística [71]

$S$ pode então ser utilizado como escore (escore log-odd) da seqüência $x$. É exatamente esse o escore fornecido pelo programa cmsearch do INFERNAL. Para facilitar os cálculos, os estados do modelo de covariância armazenam escores log-odd ao invés de probabilidades. Isto é, a cada possível emissão $B$ é associado o valor $\log \left(\frac{P(B \mid M)}{P(B \mid N)}\right)$ e a cada possível transição $t$ é associado o valor $\log \left(\frac{P(t \mid M)}{P(t \mid N)}\right)=\log (P(t \mid M)$ ) (pois o modelo $N$ é posição independente, sendo composto de apenas um estado com uma transição recursiva de probabilidade 1). Dessa forma, o escore de um caminho é a soma desses $\log$-odds de emissão e transição. Esse sistema de escore é utilizado para realizar um alinhamento "glocal" entre o modelo e o genoma: global em relação ao modelo e local em relação ao genoma, identificando subseqüências não sobrepostas de escore máximo. Como o programa cmsearch tem como objetivo identificar seqüências homólogas, ele só reporta as subseqüências que obtiveram escore maior que zero.

\subsection{Estudo de um modelo nulo adequado}

O modelo nulo representa, no caso de caracterização de TERCs, a hipótese de "não TERC", ou seja, todas as demais seqüências. A questão é como representar esse conjunto de "todas as demais seqüências". INFERNAL utiliza para isso uma distribuição não informativa (uniforme), isto é, $P(A \mid N)=P(C \mid N)=P(G \mid N)=P(T \mid N)=0.25$. No entanto, em uma busca em um genoma específico, o conjunto de "todas as demais seqüências" seria melhor caracterizado pela freqüência de nucleotídeos daquele genoma, que chamaremos aqui de distribuição de fundo $\left(P_{f}\right)$. No caso de $P$. falciparum, a distribuição de fundo é bem diferente da distribuição uniforme $\left(P_{f}(A)=P_{f}(T)=\right.$ 0.4, $\quad P_{f}(C)=P_{f}(G)=0.1$, o que torna a distribuição uniforme inapropriada para ser utilizada como modelo nulo. 
Para testar a influência desses dois e de outros modelos nulos na análise de seqüências com diferentes distribuições de nucleotídeos, calculamos a significância dos escores de seqüências reais de TERCs utilizando os diferentes modelos nulos. Ou seja, para cada TERC, foi obtido um conjunto de seqüências com a mesma distribuição de nucleotídeos do TERC, e a estas seqüências foram atribuídos escores pelos modelos de covariância construídos com os modelos nulos testados. Primeiramente, espera-se que seqüências aleatórias, apesar de possuírem a mesma distribuição de bases, recebam um escore baixo já que não são TERCs. Além disso, espera-se que o escore médio de cada conjunto de seqüências aleatórias (com mesma distribuição de um TERC) não seja dependente da distribuição de bases desse conjunto. Se isto ocorrer, o modelo não está caracterizando TERCs, e sim a proximidade a uma distribuição ótima de bases.

Para obter as seqüências com a mesma distribuição de bases, cada seqüência de TERC de ciliados e vertebrados foi embaralhada 50 vezes, obtendo a seqüência resultante de cada embaralhamento ${ }^{2}$. Os embaralhamentos de TERCs de ciliados foram analisados utilizando modelos de covariância construídos a partir de um alinhamento de TERCs de ciliados (utilizando diferentes modelos nulos) e os embaralhamentos de TERCs de vertebrados foram analisados utilizando modelos de covariância construídos a partir de um alinhamento de TERCs de vertebrados (também utilizando diferentes modelos nulos). Para cada modelo, os escores log-odd dessas seqüências foram obtidos utilizando o programa cmalign ${ }^{3}$. Os resultados utilizando cada modelo nulo foram representados em um gráfico onde cada ponto representa a média dos escores dos embaralhamentos do mesmo TERC em função de suas porcentagem de nucleotídeos G e C (figura 5.6).

Os gráficos 5.6A e 5.6C mostram que o modelo nulo uniforme, utilizado como modelo nulo default pelo INFERNAL, faz com que o escore log-odd tenha uma dependência do conteúdo GC. Essa dependência é inversa para ciliados e direta para vertebrados. TERCs de ciliados são em média $37 \% \mathrm{GC}$, enquanto de vertebrados são em média $66 \% \mathrm{GC}$. Como o modelo nulo uniforme não considera essa tendência, o escore log-odd capta a similaridade do conteúdo GC da seqüência sendo analisada com o conteúdo GC das seqüências utilizadas na construção do modelo de covariância. Por isso seqüências mais ricas em AT tiveram maior escore no modelo ciliado, enquanto seqüências mais ricas em GC tiveram maior escore no modelo vertebrado. A questão é que essa atribuição de escore nada tem a ver com a adequação da seqüência ao modelo, e sim à mera composição de nucleotídeos.

Os gráficos 5.6B e 5.6D mostram que os resultados obtidos a partir do uso do modelo nulo de

\footnotetext{
${ }^{2}$ Esses embaralhamentos foram feitos sem alterar o template telomérico. Isso porque, como descrito na subseção 5.3.2, o sistema TERP exige o reconhecimento desse template.

${ }^{3} \mathrm{O}$ programa cmalign, ao invés de alinhar localmente a seqüência ao modelo, como faz o cmsearch, alinha a seqüência globalmente, atribuindo um escore, mesmo que negativo, correspondente à seqüência inteira.
} 

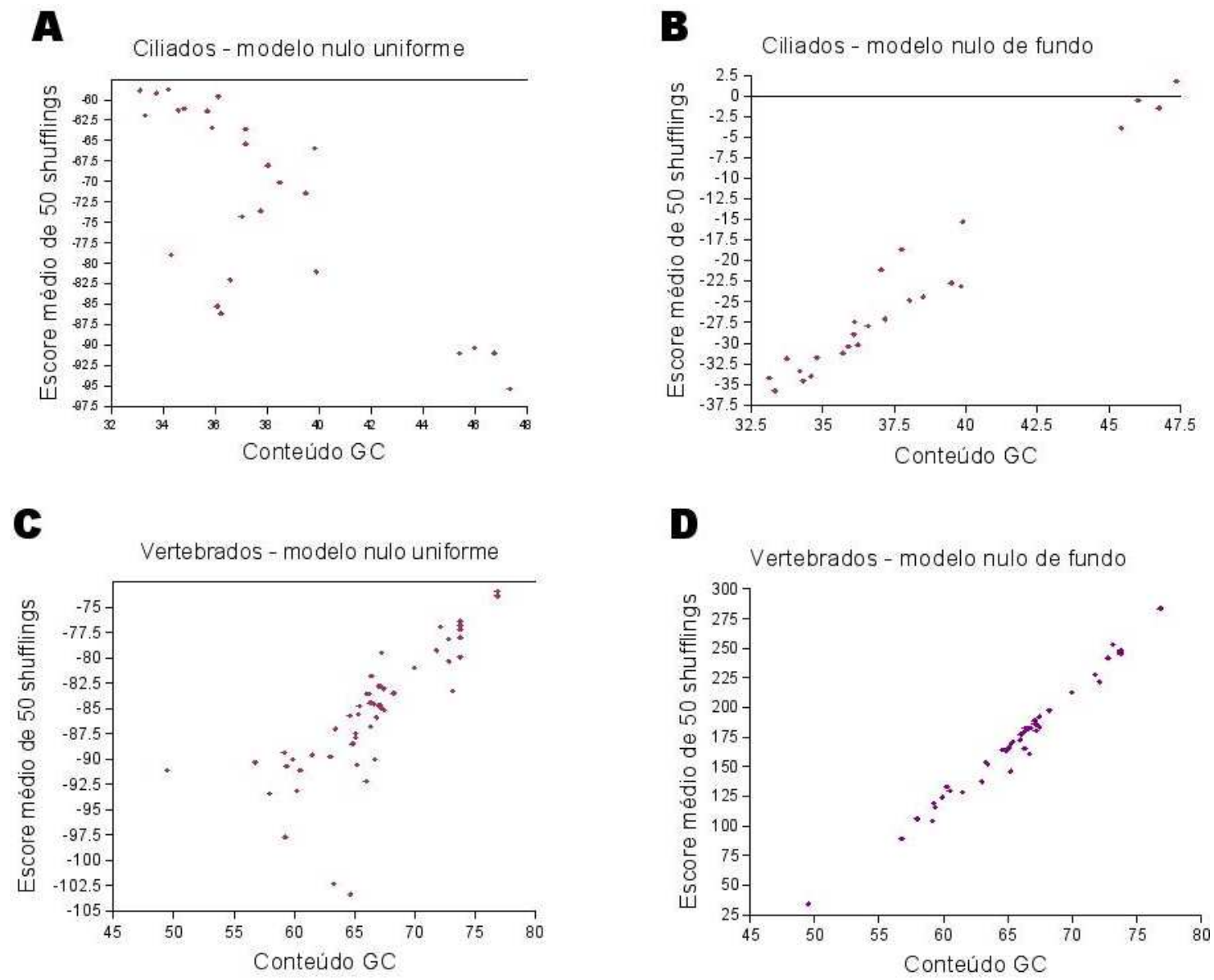

Figura 5.6: Escores médios de 50 shufflings de cada TERC. A: TERCs de ciliados utilizando alinhamento de ciliados e modelo nulo uniforme; B: TERCs de ciliados utilizando alinhamento de ciliados e modelo nulo igual à distribuição de fundo de P. falciparum; C: TERCs de vertebrados utilizando alinhamento de vertebrados e modelo nulo uniforme; D: TERCs de vertebrados utilizando alinhamento de vertebrados e modelo nulo igual à distribuição de fundo de $P$. falciparum.

fundo de $P$. falciparum, defendido como apropriado para genomas com viés composicional, foram ainda piores que os obtidos com o modelo uniforme. Testes tanto do modelo ciliado quanto do modelo vertebrado revelaram forte dependência direta dos escores em relação ao conteúdo GC. Ainda pior, para seqüências com aproximadamente $47.5 \% \mathrm{GC}$ no modelo ciliado e para todas as seqüências no modelo vertebrado, a média dos escores das seqüências aleatórias assume valores positivos. Ou seja, essas seqüências seriam erroneamente classificadas como TERCs. Esses resultados devem-se ao fato de que, como a distribuição de fundo de $P$. falciparum atribui altas probabilidades para A e T, ocorrências desses nucleotídeos são altamente penalizadas, já que o escore log-odd de um nucleotídeo $B$ é dado por $\log (P(B \mid M))-\log (P(B \mid N))$, onde $P(B \mid N)$ é a probabilidade atribuída 
ao nucleotídeo $B$ pelo modelo nulo. Desta forma, seqüências ricas em GC foram privilegiadas.

A fim de diminuir o efeito da tendência de captura do conteúdo GC das seqüências de treinamento do modelo de covariância, testamos um modelo nulo que possui a mesma distribuição de nucleotídeos das seqüências de treinamento, ou seja, de TERCs de ciliados para o modelo ciliado e de TERCs de vertebrados para o modelo vertebrado. Utilizando esse modelo nulo de treinamento com o modelo ciliado, os escores das seqüências aleatórias não mais apresentaram dependência do conteúdo GC (figura 5.7A). No entanto, o mesmo não aconteceu com o modelo vertebrado, que ainda apresentou forte dependência do conteúdo GC (figura 5.7B).
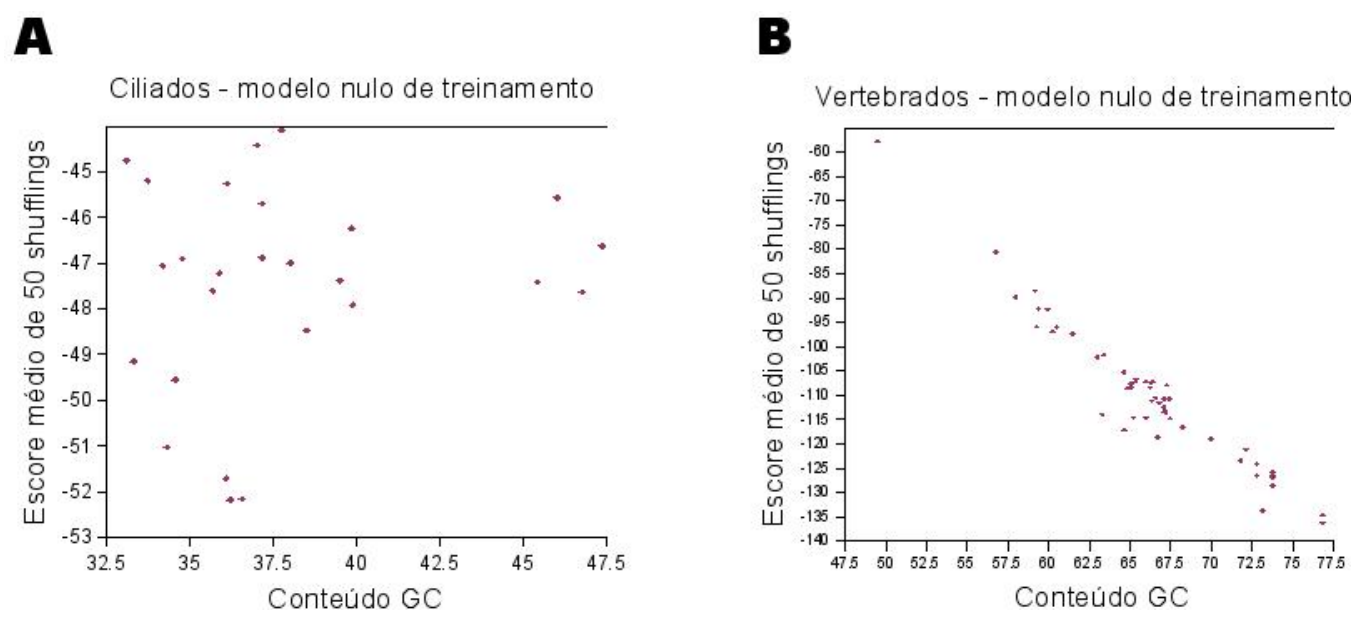

Figura 5.7: Escores médios de 50 shufflings de cada TERC utilizando como modelo nulo a composição de bases das sequiências de treinamento. A: TERCs de ciliados utilizando alinhamento de ciliados; B: TERCs de vertebrados utilizando alinhamento de vertebrados.

A distribuição de fundo seria apropriada se todo o genoma tivesse a mesma distribuição. Desta forma uma seqüência não seria selecionada por não se adequar à distribuição do modelo nulo, mas sim por se adequar bem ao modelo de covariância. No entanto, sabe-se que a distribuição de nucleotídeos não é homogênea pelo genoma de um organismo. A solução encontrada para contornar esse problema é assumir uma distribuição de fundo local. Ou seja, é construído um modelo nulo específico para cada seqüência, sendo este definido pela freqüência de nucleotídeos da própria seqüência. Esse modelo, aqui chamado de modelo nulo query, é bastante estringente no sentido que uma seqüência tem que se adequar melhor ao modelo de covariância do que ao modelo de sua própria composição de bases. Resultados utilizando esse modelo para ciliados e vertebrados (figuras 5.8A e 5.8B) mostram desaparecimento da dependência do conteúdo GC tanto em ciliados quanto em vertebrados. Tais resultados indicam que o modelo nulo query é um modelo nulo apropriado para a realização de buscas em um genoma, mesmo um com viés composicional. 


\section{$\mathbf{A}$}

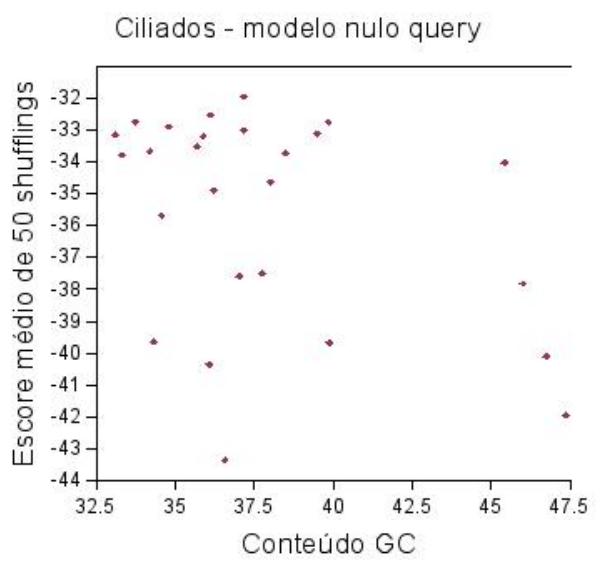

Vertebrados - modelo nulo query

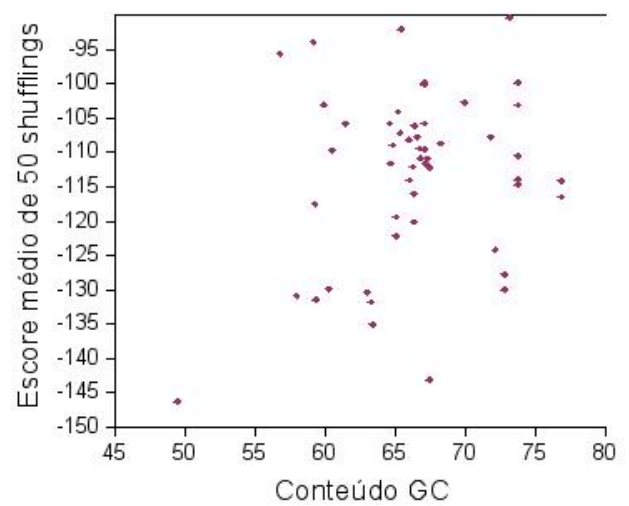

Figura 5.8: Escores médios de 50 shuffings de cada TERC utilizando como modelo nulo a composição de bases da seqüência query. A: TERCs de ciliados utilizando alinhamento de ciliados; B: TERCs de vertebrados utilizando alinhamento de vertebrados.

\subsection{Métodos}

Como descrito na seção 5.1.1, a construção de um modelo de covariância exige um alinhamento estrutural das seqüências de interesse. Esta seção descreve como alinhamentos de TERCs foram obtidos (subseção 5.3.1), o sistema TERP (subseção 5.3.2) e os métodos utilizados nos testes (subseção 5.3.3) e nas aplicações em espécies sem TERC conhecida (subseção 5.3.4).

\subsubsection{Alinhamentos de TERCs}

Os alinhamentos de TERCs de ciliados e de vertebrados foram obtidos do banco de dados Rfam [100, 101]. Ajustes manuais foram feitos nesses alinhamentos de forma a corrigir erros de alinhamento, seqüências e anotação de estrutura. Esses ajustes foram feitos considerando dados publicados tanto de ciliados $[54,149,158,179,180,196,222,261,294]$ quanto de vertebrados $[35,36,37,39,155,269]$. Ao alinhamento de ciliados também foram adicionadas outras seqüências de TERCs não presentes no Rfam. No total, há 27 seqüências no novo alinhamento de ciliados e 37 no novo alinhamento de vertebrados.

Não havia um alinhamento de TERCs de leveduras. Tal alinhamento foi construído com seqüências de TERCs de 7 espécies de Saccharomyces com base na predição da estrutura secundária consenso destas seqüências $[56,88,157,298]$. Não foi possível adicionar a este alinhamento seqüências de TERCs de outras leveduras (Kluyveromyces) por dois motivos. Primeiro, suas seqüências são muito divergentes das seqüências de Saccharomyces, impedindo um alinhamento baseado na seqüência primária e, segundo, não há uma predição da estrutura secundária completa para TERCs de 
Kluyveromyces [268], impedindo um alinhamento estrutural.

A edição dos alinhamentos foi realizada com o auxílio da ferramenta RALEE [99]. Devido à alta divergência em tamanho e estrutura entre TERCs de ciliados, vertebrados e leveduras, não foi possível construir um alinhamento único envolvendo os três grupos. Os três novos alinhamentos, de ciliados, vertebrados e leveduras, foram submetidos ao Rf am.

\subsubsection{O sistema TERP}

TERP é um sistema composto de programas escritos na linguagem Perl que executam diversas etapas envolvidas na identificação de TERCs em um genoma. Essas etapas, descritas na figura 5.9, são seleção de pré-candidatos, geração de modelos de covariância, adaptação desses modelos para reconhecimento do template telomérico do organismo em questão e do sistema de escore para modelos nulos específicos, análise dos candidatos e teste de significância de seus escores. Três importantes parâmetros de entrada obrigatória são: (i) o arquivo contendo o genoma a ser analisado, (ii) o template telomérico deste genoma (sem extensões) e (iii) o alinhamento estrutural a ser utilizado nas análises (ciliados, vertebrados ou leveduras). O template é descrito seguindo a nomenclatura IUPAC [126] de forma a permitir a entrada de seqüências degeneradas. Os demais valores, utilizados na descrição das etapas a seguir, são os valores default de parâmetros não obrigatórios. Todos os parâmetros são definidos em um único arquivo de configuração que é lido pelo programa principal.

\section{1 - Seleção de pré-candidatos}

Serão identificados como pré-candidatos a TERC subseqüências do genoma que possuam o template telomérico e sua extensão. Como os telômeros são composto de templates consecutivos, estes podem fornecer falsos positivos. Por esse motivo seqüências teloméricas são mascaradas. Esse mascaramento é realizado através do programa cross_match [47], utilizando como seqüência query uma seqüência repetitiva de templates.

Após esse mascaramento, a seleção de pré-candidatos ocorre em três etapas:

i Identificação de ocorrências do template: Inicialmente, o sistema identifica todas as ocorrências do template telomérico com extensão de 2 bases, tamanho mínimo de extensão encontrado entre os TERCs conhecidos. Essas ocorrências são identificadas nas duas fitas do genoma.

ii Filtro de seqüências template-repetitivas: Pode haver regiões internas no genoma que possuem uma concentração de repetições da mesma seqüência do template. Nos genomas estudados, seqüências ricas nessas repetições apresentaram alto escore com alta significância. Considerando que os TERCs conhecidos até o momento possuem apenas uma ocorrência do template, 


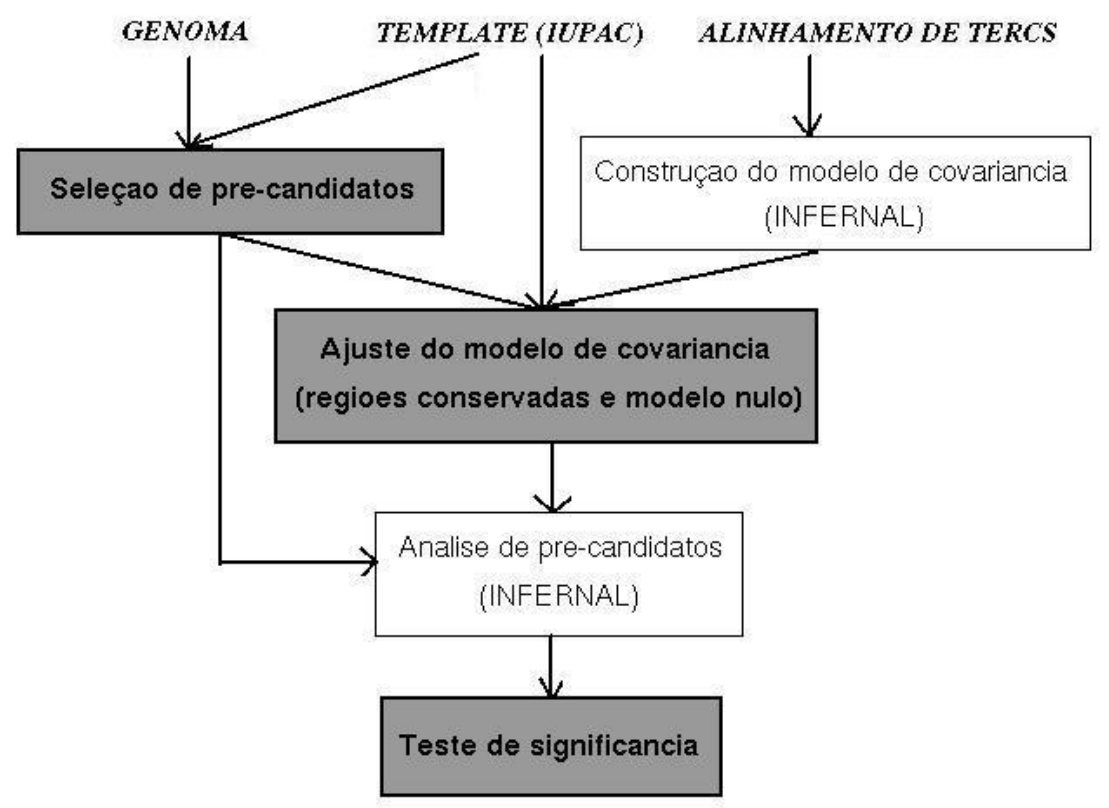

Figura 5.9: Etapas de processamento do sistema TERP.

essas seqüências template-repetitivas aumentam a taxa de falsos positivos. Para diminuir esse efeito, o sistema possui um filtro para tais seqüências, exigindo que um candidato a TERC não possua uma segunda ocorrência do template dentro de uma região de 30 bases upstream e 100 bases downstream da posição do template sendo considerado. Esses tamanhos correspondem aos menores tamanhos de upstream e downstream, respectivamente, encontrados em TERCs de ciliados, grupo que apresenta as menores TERCs.

iii Extração de seqüências: Cada ocorrência do template que passou pelos dois filtros (mascaramento de telômeros e seqüências template-repetitivas) dará origem a um pré-candidato. O pré-candidato é a seqüência definida por uma janela ao redor do template. O tamanho dessa janela é controlado por dois parâmetros: número de bases antes do template e número de bases depois do template. Os valores default desses parâmetros são aproximadamente iguais ao número de colunas do alinhamento utilizado na construção do modelo de covariância.

\section{2 - Geração de modelos de covariância}

Um modelo de covariância é construído a partir do alinhamento estrutural de TERCs especificado. Esta etapa é feita utilizando o programa cmbuild do pacote INFERNAL. 
$3 a$ - Adaptação do modelo de covariância para reconhecimento do template

Em um alinhamento de TERCs de diferentes espécies, os templates teloméricos devem estar alinhados independentemente de suas seqüências serem idênticas ou não. Isso faz com que o modelo de covariância construído a partir desse alinhamento possua um trecho específico para reconhecimento do template. Quando um pré-candidato é analisado utilizando este modelo de covariância, sua seqüência do template deve ser alinhada com a região de reconhecimento do template do modelo de covariância. No entanto, esse alinhamento pode ocorrer em outras regiões do pré-candidato caso isso aumente o escore total do alinhamento. Esse tipo de alinhamento indesejável tem ainda mais chance de ocorrer quando a seqüência do template da espécie de interesse difere daquelas das espécies utilizadas na construção do modelo.

Para forçar o alinhamento entre a seqüência de template do pré-candidato e a região de reconhecimento do template do modelo de covariância, o sistema TERP realiza modificações no modelo de covariância. Essas modificações fazem com que a região de reconhecimento do template reconheça de forma determinística o template (e também sua extensão) da espécie de interesse no pré-candidato. Isso é feito alterando as probabilidades de emissão de símbolos nos estados de reconhecimento e as probabilidades de transição entre os estados para impedir deleções e inserções no meio do template e de sua extensão.

A figura 5.10 ilustra essas modificações para o template de $P$. falciparum com exigência de extensão de 1 base (TRAACCCT, onde $\mathrm{R}=\mathrm{G}$ ou A). Antes do template (conjunto de estados 0 na figura), inserções são permitidas e as probabilidades de emissão não são alteradas. Para cada posição interna ao template e sua extensão, com exceção da última posição (conjuntos de estados 1 a 7 na figura), não são permitidas inserções nem deleções, isto é, as probabilidades de transições chegando aos estados $I L$ e $D$ recebem valor zero, enquanto as probabilidades de transições para estados de reconhecimento $L$ recebem valor 1 . Na última posição da extensão do template (conjunto de estados 8), deleção neste conjunto de estados não é permitida, mas inserções neste conjunto e deleção no próximo conjunto de estados (conjunto 9) o são, pois só podem ocorrer após o reconhecimento da última posição da extensão. As probabilidades de emissões dos estados $L$ dos conjuntos 1 a 8 são alteradas de forma a reconhecer apenas a seqüência do template e sua extensão. Isto é feito atribuindo probabilidade uniforme somente para as bases definidas como template e extensão e 0 para as demais. Neste exemplo, probabilidade igual a 1 quando apenas um nucleotídeo é definido (conjuntos 1 a 2 e 4 a 8 ) e probabilidade igual a 0.5 para G e 0.5 para A no conjunto 3 . 


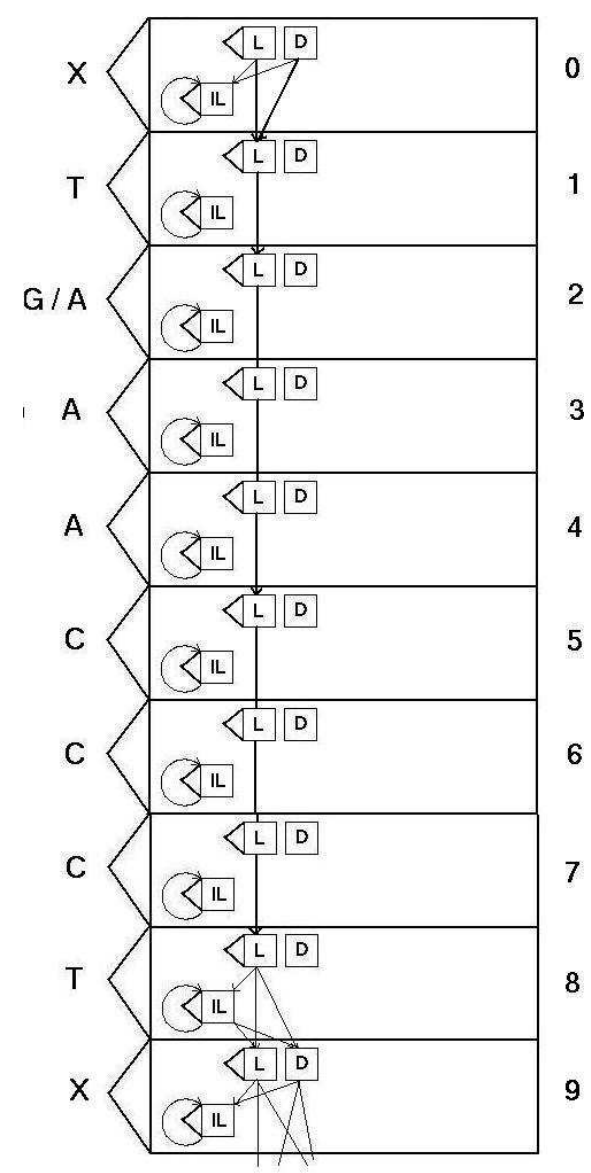

Figura 5.10: Arquitetura modificada do modelo de covariância relativo ao trecho do template telomérico e sua extensão. Flechas de transição com linhas engrossadas correspondem a transições que tiveram suas probabilidades aumentadas. Transições com probabilidade zero tiveram suas flechas removidas em relação à arquitetura original. Ao lado do triângulo de emissão estão representadas as únicas emissões possíveis. Ao lado direito um número rotula cada conjunto de estados a ser referenciado no texto.

\section{$3 b$ - Adaptação do sistema de escore para modelos nulos específicos}

O sistema TERP utiliza como modelo nulo default o modelo query. Isto exige que o modelo de covariância seja adaptado para cada pré-candidato de forma que seu escore log-odd seja calculado utilizando como modelo nulo sua freqüência de nucleotídeos. Isso é feito ajustando os escores de emissão de todos os estados. Os escores de emissão são valores calculados como

$$
s=\log (P(B \mid M))-\log (P(B \mid N))
$$

para cada valor de emissão $B$. Para que os novos escores $s^{\prime}$ assumam valores

$$
s^{\prime}=\log (P(B \mid M))-\log \left(P\left(B \mid N^{\prime}\right)\right),
$$


onde $N^{\prime}$ é o novo modelo nulo, basta calcular

$$
s^{\prime}=s+\log \left(P(B \mid N)-\log \left(P\left(B \mid N^{\prime}\right)\right),\right.
$$

uma vez que $N$ e $N^{\prime}$ são conhecidos.

Se um modelo nulo fixo é definido (ao invés de um seqüência específico, como o modelo query), esse ajuste de escores no modelo de covariância é realizado apenas uma vez, e o modelo de covariância resultante é utilizado para analisar todos os pré-candidatos.

\section{4 - Análise de candidatos}

O modelo de covariância resultante é então utilizado pelo programa cmsearch do pacote INFERNAL para buscar a subseqüência de maior escore dentro de cada pré-candidato. A princípio, somente os pré-candidatos fornecidos pelo cmsearch (isto é, com escore positivo) seriam candidatos a TERC. No entanto, a taxa de falsos negativos pode ser diminuída quando são considerados resultados com escore negativo, desde que estes apresentem alta significância (comunicação pessoal de Alex Coventry). Ou seja, candidatos que, apesar de possuírem escore negativo, têm escore superior aos escores de sequiências aleatórias. Por esse motivo, de todos os resultados, o sistema TERP seleciona para o teste de significância candidatos com escore maior ou igual a -200. A fim de permitir o uso de limiares negativos de escore para seleção de candidatos, o programa cmsearch foi alterado para fornecer resultados de escores negativos.

\section{5 - Teste de significância do score}

Somente a região de cada pré-candidato que foi alinhada ao modelo (reconhecida pelo cmsearch com escore acima de -200) é extraída, compondo a lista final de candidatos. A última etapa consiste em ordenar essa lista. Tal ordenação poderia ser feita de forma decrescente pelo escore. No entanto, a significância do escore é uma medida mais confiável para avaliar um candidato. Como mencionado anteriormente, devido à taxa de mutação dos TERCs, é possível que o TERC apresente um escore

baixo, se confundindo com o ruído das outras sequiências. A finalidade da significância do escore é colocar o verdadeiro TERC acima do ruído, tanto quanto possível.

A significância do escore de um candidato $x$ pode ser avaliada pelo seu Z-escore, que é calculado da seguinte forma:

$$
Z(x)=\frac{S_{x}-\overline{S_{x}}}{\sigma_{x}}
$$


onde $S_{x}$ é o escore do candidato $x, \overline{S_{x}}$ é a média dos escores de 100 seqüências aleatórias com a mesma distribuição de bases da seqüência $x$ (obtidas a partir de embaralhamentos da seqüência $x$ preservando o template telomérico) e $\sigma_{x}$ é o desvio padrão dos escores desse mesmo conjunto de seqüências. Ou seja, o Z-escore mede quantas vezes o escore de um candidato $x$ é maior que o escore médio de seqüências aleatórias em unidades de desvio padrão. Sendo assim, espera-se que bons candidatos tenham um alto Z-escore.

\section{Circularização do template}

Como o telômero é formado de repetições consecutivas, não há certeza, na ausência de dados experimentais, do início e término exatos de uma unidade de repetição sintetizada pelo complexo telomerase. Isto é, se um trecho de telômero é GGGTTTAGGGTTTAGGGTTTAGGGTTTA, todos os templates TAAACCC, AAACCCT, AACCCTA, ACCCTAA, CCCTAAA, CCTAAAC e CTAAACC são possíveis a princípio. Permutações circulares deste tipo foram detectadas em algumas espécies de ciliados que compartilham a mesma repetição telomérica em seus cromossomos [158].

Para considerar essa possibilidade, todo o processo descrito acima é repetido para cada possível circularização do template.

\subsubsection{Testes em vertebrados}

Para testar o sistema TERP e também o poder de identificação do modelo de covariância de TERCs, realizamos um teste de validação cruzada leave-one-out. Neste teste o sistema é executado $n$ vezes onde, em nosso caso, $n$ é o número de seqüências no alinhamento de TERCs utilizado na construção do modelo de covariância. Para cada espécie representada no alinhamento, um novo alinhamento é obtido através da remoção do TERC daquela espécie. Esse novo alinhamento é então utilizado pelo sistema para buscar candidatos a TERC no genoma desta espécie.

Devido ao fato do grupo de vertebrados possuir mais espécies com genoma seqüenciado, utilizamos o alinhamento de TERCs de vertebrados para realizar este teste.

O genomas de Bos taurus (boi), Gallus gallus (galinha), Homo sapiens (ser humano), Mus musculus (camundongo) e Rattus norvegicus (rato) foram obtidos do banco de dados Ensembl [82].

Os genomas de Dasypus novemcinctus (tatu), Elephas maximus (elefante) e Oryctolagus cuniculus (coelho) foram obtidos do Broad Intitute [23].

O genoma de Sus scrofa (porco) foi obtido do Sanger Centre [233].

Os genomas de Equus caballus (cavalo), Felis catus (gato) e Cavia porcellus (porquinho da Índia) estão em processo de seqüenciamento, e seus contigs foram obtidos do Genbank [94].

Os genomas dos demais vertebrados presentes no alinhamento não estão seqüenciados. Para 
realizar os testes, foram obtidas todas as seqüências desses organismos (incluindo a seqüência do TERC) presentes no GenBank, e estas foram concatenadas em uma única seqüência a ser utilizada como um genoma artificial. São eles: Anodorhynchus hyacinthinus (arara azul), Bufo japonicus (sapo), Ceratophrys ornata (sapo), Chelydra serpentina (tartaruga), Chinchilla brevicaudata (chinchila), Cricetulus griseus (hamster), Dasyatis sabina (raia-prego), Dasyurus hallucatus (quoll), Dermophis mexicanus (anfíbio), Geomys breviceps (roedor), Herpele squalostoma (anfíbio), Microtus ochrogaster (arganaz-do-campo), Mus spretus (camundongo selvagem do oeste), Mustela putorius furo (ferret), Mustelus canis (tubarão canejo), Procyon lotor (racum), Pyxicephalus adspersus (sapo boi), Rhinoptera bonasus (raia ticonha), Rhizoprionodon porosus (tubarão rabo seco), Suncus murinus (house shrew), Trichechus manatus (manati), Tupaia glis belangeri (tree shew), Typhlonectes natans (anfíbio) e Xenopus laevis (sapo).

Além destes, o genoma de Gallid herpesvirus, apesar de ser este um vírus, foi aqui incluído devido à alta identidade de $88 \%$ de seu TERC em relação ao TERC de seu hospedeiro, Gallus gallus (galinha) [89].

Para que os candidatos apontados pelo sistema fossem facilmente classificados como falsos ou verdadeiros, foi obtida a localização exata do TERC no genoma de cada espécie através da ferramenta WU-BLAST [290] de alinhamento local.

\subsubsection{Aplicação em organismos sem TERC conhecida}

A motivação deste trabalho foi a identificação de candidatos a TERC em Plasmodium falciparum. No entanto, aplicamos o sistema TERP também em outros organismos sem TERC conhecida.

Vertebrados As espécies testadas de vertebrados foram Pan troglodytes (chimpanzé) e Canis familiares (cachorro), cujos genomas foram obtidos do banco de dados Ensembl [82]. Em ambos os testes foi utilizado o template TAACCC com a exigência de extensão de tamanho 2. Apenas o alinhamento de TERCs de vertebrados foi utilizado para realizar as buscas.

Plasmódios Buscamos candidatos a TERCs em três espécies de Plasmodium: P. falciparum, $P$. vivax e $P$. yoelii. $P$. vivax é outra espécie de plasmódio causadora de malária em seres humanos. Seu genoma foi seqüenciado e está em fase de montagem pelo TIGR [263], de onde os contigs foram obtidos com permissão. $P$. yoelii é uma espécie que causa malária em roedores, e seu genoma já foi completamente seqüenciado [29]. Os genomas de $P$. falciparum e $P$. yoelii foram obtidos do PlasmoDB versão 5.0 [253]. A disponibilidade desses três genomas permite a realização de uma análise comparativa entre os candidatos das três espécies. Espera-se que, se o TERC de cada espécie estiver nas listas de candidatos, o cruzamento das listas (via alinhamentos de candidatos de 
diferentes espécies) forneça evidência extra a um candidato. Para as três espécies de plasmódios, o sistema TERP foi aplicado utilizando tanto o alinhamento de TERCs de ciliados quanto o de vertebrados. Foi utilizado como template a seqüência TRAACCC ( $\mathrm{R}$ simbolizando $\mathrm{G}$ ou A) ${ }^{4}$ com exigência de extensão de apenas um nucleotídeo.

\subsection{Resultados}

\subsubsection{Testes em vertebrados}

Das 37 espécies testadas, todas apresentaram o TERC como primeiro candidato na lista. Os resultados são apresentados na tabela 5.2 por ordem decrescente de Z-escore do primeiro candidato. A tabela mostra o Z-escore do primeiro e do segundo candidato, assim como o log-odd escore do primeiro candidato. A ausência de valor para o segundo Z-escore indica que somente um candidato foi identificado para aquela espécie.

As espécies que obtiveram maior Z-escore são de mamíferos. Esse fato deve ser explicado pelo grande número de TERCs de mamíferos presentes no alinhamento, causando uma tendência de sobre-valorização de seqüências similares a estas. Os altos escores log-odd atribuídos a esses TERCs confirmam essa hipótese.

Alguns TERCs receberam escore log-odd negativo e, apesar disso, puderam ser identificados. O TERC de galinha, em particular, apesar de ter recebido o terceiro menor escore log-odd (-31.32) recebeu um Z-escore superior à metade das espécies testadas (22.12). Tal resultado incentiva a estratégia de não descartar seqüências de escore negativo para posterior análise de significância de escore.

O primeiro e segundo candidatos de G.herpesvirus possuem valores de Z-escore muito próximos. $\mathrm{Na}$ verdade o segundo candidato é também um TERC. Este vírus é a única espécie conhecida que possui duas cópias deste gene no genoma. B.taurus, por outro lado, possui um pseudo-gene de TERC. Este foi identificado como segundo candidato.

\subsubsection{Aplicação em organismos sem TERC conhecida}

\section{Vertebrados}

Os resultados da execução do TERP em P.troglodytes (chimpanzé) e C.familiares (cachorro) são apresentados na tabela 5.3.

\footnotetext{
${ }^{4}$ As repetições GGGTTTA e GGGTTCA compõem $80 \%$ dos telômeros de $P$. falciparum, e são também consideradas as repetições mais freqüentes em $P$. vivax [60] e $P$. yoelii (através de análise deste genoma).
} 
Tabela 5.2: Resultados de validação leave-one-out em vertebrados. A tabela está ordenada pela coluna 3.

\begin{tabular}{|c|c|c|c|c|}
\hline Espécie & taxonomia & $1^{o} \mathrm{Z}$-escore & $2^{o}$ Z-escore & $\log$-odd score do $1^{o} \mathrm{Z}$-escore \\
\hline Cavia porcellus & mamífero roedor & 44.91 & 10.3 & 249.96 \\
\hline Equus caballus & mamífero & 44.25 & 7.42 & 262.95 \\
\hline Felis catus & mamífero & 43.18 & 8.21 & 270.39 \\
\hline Dasypus novemcinctus & mamífero & 32.75 & 11.55 & 110.13 \\
\hline Procyon lotor & mamífero & 32.13 & - & 110.3 \\
\hline Trichechus manatus & mamífero aquático & 30.93 & - & 94.63 \\
\hline Bos taurus & mamífero & 29.78 & 23.41 & 82.27 \\
\hline Sus scrofa & mamífero & 29.56 & 4.64 & 100.14 \\
\hline Homo sapiens & mamífero primata & 29.11 & 11.87 & 111.21 \\
\hline Oryctolagus cuniculus & mamífero & 27.41 & 12.35 & 107.24 \\
\hline Mustela putorius furo & mamífero & 26.74 & - & 120.98 \\
\hline Chinchilla brevicaudata & mamífero roedor & 25.77 & - & 88.55 \\
\hline Xenopus laevis & anfíbio & 24.9 & 9.18 & 86.38 \\
\hline Tupaia glis belangeri & mamífero & 24.53 & 4.68 & 96.4 \\
\hline Geomys breviceps & mamífero roedor & 24.3 & - & 76.68 \\
\hline Mustelus canis & tubarão & 23.69 & - & 61.95 \\
\hline Rhizoprionodon porosus & tubarão & 22.2 & - & 47.87 \\
\hline Gallus gallus & ave & 22.12 & 16.56 & -31.32 \\
\hline Microtus ochrogaster & mamífero roedor & 19.39 & - & 18.64 \\
\hline Cricetulus griseus & mamífero roedor & 18.89 & 14.07 & 33.48 \\
\hline Suncus murinus & mamífero & 18.58 & 3.44 & 30.74 \\
\hline Herpele squalostoma & anfíbio & 17.34 & - & 6.8 \\
\hline Dermophis mexicanus & anfíbio & 17.29 & - & 16.98 \\
\hline Dasyatis sabina & raia & 16.86 & - & 3.46 \\
\hline Typhlonectes natans & anfíbio & 16.64 & - & 5.81 \\
\hline Rattus norvegicus & mamífero roedor & 16.4 & 11.39 & 26.33 \\
\hline Chelydra serpentina & réptil & 15.78 & - & -10.76 \\
\hline Anodorhynchus hyacinthinus & ave & 15.44 & - & -8.68 \\
\hline Mus spretus & mamífero roedor & 15.42 & 5.12 & 5.9 \\
\hline Mus musculus & mamífero roedor & 15.19 & 13.5 & 7.59 \\
\hline Elephas maximus & mamífero & 14.95 & 7.67 & -48.10 \\
\hline Gallid herpesvirus & vírus de ave & 13.59 & 13.21 & -46.01 \\
\hline Dasyurus hallucatus & mamífero marsupial & 12.94 & - & -24.81 \\
\hline Rhinoptera bonasus & raia & 12.55 & - & -12.28 \\
\hline Pyxicephalus adspersus & anfíbio & 12.11 & - & -30.09 \\
\hline Ceratophrys ornata & anfíbio & 11.44 & - & -24.12 \\
\hline Bufo japonicus & anfíbio & 10.95 & - & -30.08 \\
\hline
\end{tabular}


Tabela 5.3: Resultados da aplicação do TERP na busca de candidatos a TERP em vertebrados sem TERC conhecida.

\begin{tabular}{llll}
\hline Espécie & $1^{\circ}$ Z-escore & $2^{\circ}$ Z-escore & $\log$-odd score do $1^{\circ}$ Z-escore \\
\hline & & & \\
Canis familiares & 28.34 & 7.97 & 58.58 \\
Pan troglodytes & 33.88 & 11.39 & 107.56 \\
\hline
\end{tabular}

Apesar de não termos feito uma validação biológica destes candidatos, acreditamos que, devido aos seus altos Z-escores e escores log-odd, eles são bons candidatos a TERCs e provavelmente são resultados positivos. 


\section{Plasmódios}

Utilizando o alinhamento de TERCs de vertebrados, o TERP não identificou nenhum candidato em Plasmodium falciparum.

Utilizando o alinhamento de TERCs de ciliados, o TERP forneceu uma lista de candidatos para as três espécies. O alinhamento entre os candidatos das listas de $P$. falciparum e de $P$. vivax revelou 5 pares de candidatos conservados entre as duas espécies. Destes 5, 4 estão anotados como genes de proteína, restando 1 candidato. O alinhamento entre as listas de $P$. falciparum e de $P$. yoelii revelou 4 pares de candidatos conservados entre as duas espécies. Destes 4, 2 estão anotados como genes de proteína e 1 é uma região com repetidos templates que passou pelo filtro, restando também 1 candidato. O candidato de $P$. falciparum conservado em $P$. vivax é o mesmo conservado em $P$. yoelii. Estes três candidatos foram então selecionados para uma validação biológica inicial através da realização de experimentos de RT-PCR (em execução).

Da lista original de candidatos de $P$. falciparum ordenada por significância de escore, o primeiro, o terceiro e o quinto candidatos estão anotados como outros genes. O segundo candidato é o conservado nas duas outras espécies de plasmódios testadas aqui. O quarto candidato de P. falciparum foi também selecionado para a validação biológica inicial.

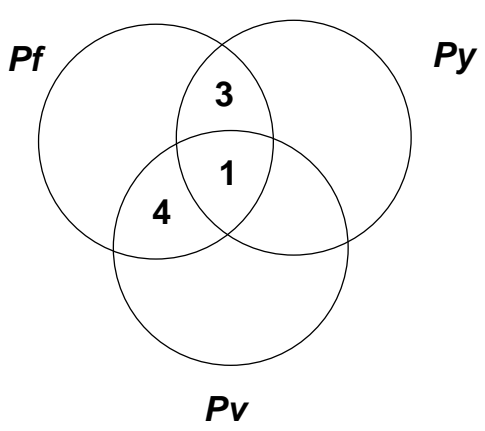

Figura 5.11: Interseç̧ão de candidatos preditos pelo sistema TERT em P. falciparum, P. yoelii e P. vivax. 


\section{Conclusões e trabalhos futuros}

\subsection{Conclusões}

Em 1958, Francis Crick dizia que "os biólogos não deveriam enganar-se com a idéia de que alguma nova classe de moléculas biológicas, de importância comparável à das proteínas, ainda estava por ser descoberta, pois isto parecia ser altamente improvável" [75]. Três anos depois, em 1961, Jacob e Monod inovaram, propondo que genes estruturais produzem RNAs mensageiros que codificam proteínas, enquanto genes regulatórios produzem RNAs funcionais [127]. Considerando as atuais evidências, Jacob e Monod estão mais próximos da realidade.

Muitos ncRNAs têm sido descobertos associados a diversas tarefas celulares e também a doenças complexas como câncer [52, 137, 213, 214], doenças neurológicas [86, 207, 221], doenças cardíacas [124], distrofia miotônica [198], disceratosis congênita [6] e outras [52, 198]. É provável que estejamos vendo ainda apenas a ponta de um iceberg de RNAs funcionais. Para avançarmos, são necessárias tecnologias otimizadas para o estudo dessas moléculas.

Uma das contribuições desse trabalho foi uma revisão das tecnologias de bioinformática desenvolvidas até o momento para a pesquisa de ncRNAs. As soluções foram organizadas pelo tipo de problema tratado e pela abordagem utilizada. Foram considerados os problemas de predição de estrutura secundária, comparação estrutural e identificação de ncRNAs. Esta revisão foi submetida a uma edição especial sobre RNAs na revista Journal of Mathematical Biology.

Nesta revisão, ficou evidente que não há uma ferramenta que resolva um dos três problemas (predição de estrutura secundária, comparação estrutural e identificação) para todos os tipos de RNAs. Uma boa prática é escolher cuidadosamente um conjunto de métodos aplicáveis utilizando diferentes abordagens e comparar os resultados. Inserção de conhecimento a priori é uma estratégia poderosa, que é particularmente relevante na pesquisa de ncRNAs, onde o espaço de soluções é freqüentemente grande. Para predição de estrutura secundária, estruturas alternativas devem ser analisadas ao invés de considerar apenas a estrutura ótima, restrições devem ser inseridas se há a 
disponibilidade de informação parcial sobre a estrutura, o processo de dobramento deve ser analisado por ferramentas cinéticas, e métodos comparativos devem ser também utilizados se sequiências homólogas estiverem disponíveis. Para a busca de ncRNAs, diferentes métodos adequados ao ncRNA de interesse devem ser usados, a fim de construir um conjunto de candidatos.

A abordagem termodinâmica tem mostrado os melhores resultados para predição de estrutura secundária ab initio. Assim, muitos dos métodos que realizam uma análise do espaço de estruturas, tais como os de densidade de estados, são baseados nesta abordagem. Recentemente, um novo método utilizando modelos probabilísticos, CONTRAfold [67], ultrapassou o desempenho dos melhores preditores termodinâmicos pela primeira vez. Um próximo passo é explorar o uso deste modelo na análise do espaço de estruturas.

Métodos incorporando modelos evolucionários têm apresentado resultados promissores. Em particular, um detector geral de ncRNAs que usa uma estratégia comparativa, eQRNA [217], parametriza o tempo de divergência entre duas seqüências sendo comparadas. A mesma abordagem poderia ser adotada por detectores treináveis de ncRNAs, adaptando seus parâmetros de acordo com a distância filogenética entre a seqüência sendo analisada e aquelas usadas na amostra de treinamento.

Apesar da existência de um grande número de ferramentas de bioinformática para a análise de ncRNAs, Plasmodium falciparum é ainda um desafio para a pesquisa nesta área. Poucos ncRNAs foram identificados neste organismo até o momento. Além disso, $P$. falciparum é o parasita que causa uma malária humana letal. A descoberta de novos ncRNAs e suas funcionalidades deve ampliar o conhecimento da fisiologia deste organismo e, portanto, auxiliar no desenvolvimento de novos tratamentos. Estas características motivaram a escolha deste organismo como objeto de estudo. Foram estudadas duas diferentes estratégias de predição: análise comparativa para predição de ncRNAs em geral e análise $a b$ initio para predição de RNAs família-específicos.

Para a análise comparativa, foi adotada a ferramenta eQRNA [217], que analisa alinhamentos entre dois genomas e os classifica como sendo de ncRNAs, proteínas ou outro (não classificado). Foram utilizados os genomas de Plasmodium falciparum e Plasmodium yoelii, duas espécies filogeneticamente próximas e com genoma seqüenciado. Foram calculados uma matriz de similaridade e penalidades de abertura e fechamento de gaps específicos para a composição de bases de $P$. falciparum e $P$. yoelii e para uma identidade alvo de $65 \%$. Para o cálculo de significância dos escores obtidos com essa matriz e penalidades, foram estimados empiricamente os parâmetros da distribuição de Gumbel. Estes dados foram utilizados na ferramenta WU-BLAST [290] para obter alinhamentos locais entre os genomas de Plasmodium falciparum e Plasmodium yoelii. Dos alinhamentos classificados como sendo alinhamentos de RNAs, 2.524 coincidem com genes anotados como proteína (das quais 1.884 são hipotéticas, 450 são putativas e 190 confirmadas), 43 coincidem com genes anotados ou preditos como ncRNA e os 323 restantes são candidatos a novos ncRNAs. Cabe ressaltar que essa estratégia 
identificou $81 \%$ dos genes de ncRNAs anotados em $P$. falciparum ${ }^{1}$.

As 2.524 regiões conservadas classificadas como ncRNAs que sobrepõem-se a anotações de genes de proteína podem não ser todas falsos positivos. Destas 2.524 regiões, 1.884 estão anotadas como proteínas hipotéticas, ou seja, resultado apenas de predição ab initio sem validação biológica. Para uma busca mais sensível, seria necessário verificar a confiabilidade dessas anotações, adicionando à lista de ncRNAs candidatos que coincidem com uma anotação duvidosa. Um exemplo que exige uma melhor análise é o do SRP RNA, predito em [224]. Sua seqüência foi também classificada como ncRNA em nossas análises. No entanto, foi considerada falso positivo por coincidir com uma anotação de uma RNA helicase putativa (PF14_0183). Esta anotação está na mesma fita na qual estaria o SRP RNA.

Outro ponto relevante é que a detecção dessas sobreposições não fez distinção entre as fitas de DNA, uma vez que a ferramenta eQRNA não indica em qual fita está o candidato a ncRNA (ou proteína) por ela classificado ${ }^{2}$. Se algumas dessas regiões forem ncRNAs reais antisenso a uma proteína, elas foram erroneamente consideradas falsos positivos. Essa é uma possibilidade real, uma vez que já foi demonstrada a presença de transcrição antisense em P. falciparum [184]. De fato, 4 dessas regiões classificadas como ncRNAs coincidem com genes de proteínas que apresentaram atividade de transcrição antisense dependente de RNA polimerase II em [184] : 2 genes de calmodulina (PF10_0301 e PF14_0323), msp3 (merozoite surface protein 3) (PF10_0345) e kahrp (knob-associated histidine-rich protein) (PFB0100c).

Até onde sabemos, é a primeira vez que essa abordagem é utilizada para a identificação de genes de ncRNAs em Plasmodium falciparum. O sistema de escore e parâmetros de significância calculados neste trabalho não estão limitados a essa aplicação. Ao contrário, eles podem sempre ser utilizados para a realização de alinhamentos locais (buscas por BLAST) entre seqüências $P$. falciparum $\times$ $P$. yoelii, independentemente das seqüências serem de ncRNAs, proteínas ou intergênicas, desde que a identidade alvo seja de aproximadamente $65 \%$.

Para a análise $a b$ initio de predição de RNAs família-específicos, a família de TERCs foi escolhida como objeto de estudo. O TERC é um importante ncRNA, pertencente ao complexo telomerase, que possui o molde da repetição telomérica. Devido à sua alta taxa de mutação, este RNA é de difícil identificação, sendo atualmente conhecido apenas em alguns ciliados, vertebrados e leveduras. Em ciliados e vertebrados, possui um tamanho variando de aproximadamente 150 a 560 bases. Portanto, são grandes o suficiente para considerarmos problemas de complexidade mas possuem ainda um tamanho tratável pelas ferramentas computacionais. Da mesma forma, sua estrutura secundária não é tão complexa como as dos SSU (Small Sub-Unit) e LSU (Large Sub-Unit) rRNAs, mas possui

\footnotetext{
${ }^{1}$ Segundo anotação obtida do PlasmoDB versão 5.1 [203, 253] e RNAs preditos em [204, 224].

${ }^{2}$ Isso porque a classificação dos alinhamentos é baseada no padrão de mutação entre as seqüências alinhadas.
} 
diversidade de componentes estruturais. Este RNA ainda não foi identificado em $P$. falciparum. No entanto, evidências biológicas e dados experimentais indicam que não só este RNA é presente e funcional no genoma deste parasita como também deve ser essencial, caracterizando-se como um alvo de drogas.

Inicialmente foi feita uma abordagem heurística, termodinâmica e gramatical para a predição desse RNA em Plasmodium falciparum. Foram analisados os níveis de conservação de vários sinais de seqüência primária e características de estrutura secundária. Além da estrutura secundária, poucas características são conservadas em todos os TERCs conhecidos, mesmo para TERCs dentro de um mesmo grupo (ciliados, vertebrados e leveduras).

Durante o estudo de TERCs conhecidos, foi identificado que, apesar da literatura se referir ao template telomérico como sendo a seqüência antisenso de "uma repetição e meia" [186], o template de alguns TERCs possui uma extensão de apenas 2 bases [36, 180]. Este parece ser o tamanho mínimo de extensão do template para o funcionamento do complexo telomerase [36]. Curiosamente, ao considerar a repetição telomérica começando com todos os G' consecutivos (GGGGTT ou GGGGTTTT em ciliados e GGGTTA em vertebrados), a extensão mínima percebida é de 1 base de cada lado. Esta característica foi observada em todos os TERCs conhecidos de ciliados e vertebrados, e não havia sido relatada anteriormente.

Essa extensão mínima de pelo menos uma base em cada extremidade do template foi considerada pré-requisito de um candidato a TERC durante a fase de análises heurísticas. Considerando as características mais conservadas em TERCs de ciliados, foi realizada uma ordenação preliminar de candidatos a TERC em Plasmodium falciparum. Um experimento de RT-PCR realizado com os três primeiros candidatos amplificou um fragmento do primeiro candidato (rotulado como candidato 12). No entanto, este candidato não foi detectado por Northern blot nem por 5'-RACE.

O insucesso em amplificar a seqüência esperada do candidato 12 em duas execuções de 5'RACE trouxe dúvidas sobre o fato desse candidato ser realmente o TERC. A questão é de onde veio o fragmento amplificado no experimento de RT-PCR, se todos os primers utilizados foram fita-específica. Pelo menos três hipóteses podem ser levantadas:

1. O fragmento observado no RT-PCR é uma contaminação genômica. Se durante a extração de RNA o material não for devidamente tratado para eliminar moléculas de DNA, seqüências genômicas não necessariamente transcritas podem ser amplificadas. No entanto, esta probabilidade é baixa dado o fato que o protocolo utilizado realiza três tratamentos consecutivos com DNase.

2. O locus é realmente transcrito e é funcional. Poderia ser o TERC, outro ncRNA ou até mesmo um ncRNA antisenso à proteína hipotética presente na fita oposta com a finalidade de 
regulá-la pós-transcricionalmente, uma vez que é relatada atividade de transcrição antisenso em Plasmodium falciparum [103, 184]. Neste caso, se esse transcrito possuir uma estrutura secundária complexa e/ou for muito longo, a transcriptase reversa pode não conseguir copiar o RNA até a sua extremidade 5' durante o RACE. Já no RT-PCR, a enzima não teria tido esses problemas devido ao curto tamanho do fragmento sendo amplificado. Ou ainda pode ser que o transcrito seja instável e tenha sido degradado.

3. A proteína hipotética localizada antisense ao candidato 12 é funcional e o transcrito do candidato 12 é não funcional, decorrente de transcrição relaxada observada em P. falciparum [209]. Neste caso, a transcriptase reversa poderia ter tido dificuldades em copiá-lo pelos mesmos motivos da segunda hipótese.

Foi também utilizada uma abordagem gramatical para a identificação do TERC. Gramáticas livres de contexto estocásticas são capazes de caracterizar seqüências de RNAs e suas estruturas secundárias, e foram aplicadas aqui para o problema de identificação de TERCs. A aplicação direta de INFERNAL [76], ferramenta referência na identificação de ncRNAs que implementa um modelo de covariância equivalente a GLCEs, não produziu resultados satisfatórios. A análise sintática do modelo gerado pelo INFERNAL é capaz de reconhecer qualquer seqüência. Com isso a seqüência desejada se perde no ruído das demais seqüências quando ela é muito divergente da amostra de treinamento. Por esse motivo foi realizada uma abordagem de desenhar gramáticas manualmente de forma que informações a priori pudessem ser inseridas para aumentar a sensitividade da predição.

Infelizmente, embora tenha produzido bons resultados em um estudo preliminar de caracterização de tRNAs, essa abordagem não teve o mesmo sucesso na caracterização de TERCs. A família de tRNAs é mais conservada e bem melhor caracterizada devido ao grande número de seqüências e vários estudos envolvendo essa família. O mesmo não é verdade para TERCs. Além disso, considerando as espécies dos 22 TERCs, há filos cujos TERCs apresentam maior similaridade entre si, causando uma sobre-representação de seqüência similares. Os melhores resultados com testes de validação cruzada de filos de TERCs foram os obtidos para esse grupo de filos similares. A detecção de problemas como sobre-representação de seqüências similares e rápida divergência entre TERCs de espécies mais distantes filogeneticamente revelou que era necessário uma abordagem intermediária: o poder de generalização do INFERNAL com algum controle na inferência das regras gramaticais.

Nesta direção, foi desenvolvido o sistema TERP (TElomerase RNA Predictor) para predição de candidatos a TERC em um genoma. TERP é um sistema que permite realizar uma busca por candidatos a TERC de forma rápida do ponto de vista de tempo exigido do usuário. O usuário precisa apenas ajustar parâmetros iniciais (como a seqüência do template telomérico, o arquivo contendo o genoma e o alinhamento de TERCs a ser utilizado como amostra de treinamento) e 
então é feita a busca e análise dos candidatos de forma totalmente automática. O resultado final é uma lista de candidatos ordenada por ordem de significância de escore.

O TERP utiliza o INFERNAL para construir modelos de covariância iniciais e analisar as seqüências candidatas. Além disso, o TERP faz seleção de pré-candidatos, ajusta os modelos para reconhecimento do template e modelos nulos específicos para cada seqüência e testa a significância dos escores dos candidatos.

Foi verificado que uma das causas das falhas de identificação de ncRNAs em Plasmodium falciparum é o viés composicional de seu genoma. O tratamento desse problema no sistema TERP foi baseado em um estudo realizado durante seu desenvolvimento sobre o impacto da escolha de modelos nulos no sistema de escore. Foi verificado que a utilização de um único modelo nulo não é apropriada para a análise de todo um genoma, uma vez que este freqüentemente não possui uma distribuição homogênea de bases. Essa característica ficou ainda mais evidente nos testes realizados com $P$. falciparum, que possui uma distribuição de fundo de $80.6 \%$ AT. Desta forma, o sistema incorpora o cálculo de um modelo nulo específico para cada seqüência sendo analisada, assumindo uma distribuição local de bases. Este problema de modelo nulo não é uma questão exclusiva de modelos de covariância. Esta é uma questão intrínseca ao cálculo de escores log-odd. Desta forma, a contribuição do modelo nulo query se estende a todas as ferramentas que utilizam esse tipo de escore.

A busca de candidatos em um genoma pode ser bastante demorada. Nos $23 \mathrm{Mb}$ de genoma de Plasmodium falciparum, por exemplo, a busca demora aproximadamente 121 horas (5 dias) em um máquina com processador $2 \mathrm{GHz}, 1 \mathrm{G}$ de memória RAM, rodando linux. Por esse motivo TERP possui uma opção de dividir o processamento dos pré-candidatos em scripts para serem executados em um cluster de máquinas.

Testes de validação cruzada do sistema TERP, utilizando TERCs de vertebrados, apresentaram $100 \%$ de sensitividade e $100 \%$ de especificidade em todos os casos ao considerar apenas o primeiro candidato. Sabemos que parte de tal desempenho é devido ao fato dos TERCs conhecidos de vertebrados possuírem uma razoável similaridade, e talvez por isso mesmo serem conhecidos. Utilizando o sistema nos genomas de cachorro e chimpanzé, cujo TERC não está anotado, foi identificado em cada organismo um candidato de alto escore e alta significância.

O TERP foi utilizado para predizer candidatos em três espécies de plasmódios: P. falciparum, $P$. vivax e $P$. yoelii. As seqüências dos candidatos das três listas foram comparadas, e apenas um candidato de $P$. falciparum possui similaridade com os candidatos dos outros dois plasmódios. Esses três candidatos (um de cada espécie) e mais o segundo melhor candidato de $P$. falciparum estão em processo de validação biológica. A conservação de um candidato em três espécies é uma evidência de que este pode ser o TERC ou, pelo menos, um ncRNA funcional. Outra evidência é que esse 
candidato possui a seqüência UCA antes do template, característica conservada em todos os TERCs de ciliados conhecidos até o momento.

A seqüência do candidato a TERC reconhecida pelo sistema TERP possui 196 bases. Na análise comparativa realizada para detectar ncRNAs em geral conservados em P. falciparum e P. yoelii, o alinhamento referente ao locus exato dessa seqüência foi classificado como "outro" pelo EQRNA, ou seja, sem classificação conhecida. Essa classificação porém teve baixo escore, com diferença pequena entre as classes OUTRO e RNA. O alinhamento mais próximo a este locus classificado como RNA localiza-se a 700 bases downstream. Não há anotação para essa região, e portanto sua seqüência pertence à lista de candidatos a ncRNAs.

O sistema TERP pode ser aplicado na identificação de outros genes de RNA, diferentes de TERC, que possuam uma região conservada não pareada (região de loop). Para isso, basta ajustar alguns parâmetros, como por exemplo:

- a seqüência da região conservada (que pode ser degenerada) deve ser informada para o TERP como sendo a seqüência do template, com extensão zero;

- a dimensão da janela ao redor do "template" para a seleção de pré-candidatos deve ser definida de acordo com o tamanho típico dos RNAs de interesse;

- o alinhamento estrutural de treinamento deve ser o das seqüências da família desses RNAs;

- a opção de circularização do template deve ser desligada.

A pesquisa de ncRNAs tem um logo caminho pela frente. Os métodos atuais são baseados em nosso conhecimento sobre ncRNAs. Mas, provavelmente, nós conhecemos apenas uma pequena fração do mundo dos RNAs. A inserção de hipóteses ao nosso conhecimento atual pode ajudar a descobrir novas facetas sobre este mundo e, por sua vez, melhorar as ferramentas computacionais.

Finalmente, gostaríamos de reforçar que todos os métodos computacionais citados neste trabalho fazem predições. Portanto, seus resultados não podem ser considerados a verdade suprema mesmo quando mais de um método estão em acordo. Experimentos biológicos são necessários para uma real validação de predições in silico.

\subsection{Trabalhos futuros}

A busca de ncRNAs em geral em $P$. falciparum foi baseada na hipótese de que a maioria de ncRNAs conservados entre P. falciparum e P. yoelii possuem uma porcentagem de identidade de aproximadamente $65 \%$. Poderia ser explorada a hipótese de que alguns ncRNAs podem possuir uma similaridade maior, como $80 \%$ ou $85 \%$. Para isso, uma nova matriz, novas penalidades de gaps 
e novos parâmetros de uma Gumbel deveriam ser estimados para essa nova identidade alvo, e então serem aplicados para obter novos alinhamentos entre $P$. falciparum e $P$. yoelii.

Em breve, o genoma de $P$. vivax, um plasmódio também causador de malária humana, será publicado pelo TIGR, The Institute for Genomic Research [125]. A mesma estratégia aqui descrita pode ser utilizada para identificar ncRNAs conservados em $P$. falciparum e $P$. vivax ${ }^{3}$. Devido à maior proximidade filogenética desta espécie à de $P$. falciparum, é provável que novos candidatos a ncRNAs sejam identificados.

Nada impede, porém, que outras espécies de plasmódios, seqüenciadas com inferior cobertura, sejam analisadas da mesma maneira. Pode-se, inclusive, utilizar várias espécies de plasmódios para obter alinhamentos múltiplos, que podem então ser analisados pela ferramenta RNAz [281]. Como descrito no capítulo 2, esta ferramenta, semelhantemente ao eQRNA, pode detectar se um alinhamento consiste de seqüências de ncRNAs. No entanto, RNAz pode analisar alinhamentos múltiplos, aumentando a especificidade da identificação.

Escolhemos uma abordagem comparativa de análise de alinhamentos para a detecção de ncRNAs em $P$. falciparum. No entanto, outros métodos descritos no capítulo 2 poderiam ser explorados, como o PSoL [277] e RANDFOLD [20]. PSoL é um método que treina um classificador a partir de uma amostra positiva de treinamento. Os ncRNAs conhecidos em P. falciparum poderiam ser usados como amostra de treinamento para obter um classificador. Este classificador seria então usado para analisar seqüências genômicas, classificando-as como ncRNAs ou não. Poderia também ser testada a inserção de ncRNAs de $P$. yoelii nesta amostra de treinamento. Já o RANDFOLD calcula a significância da energia livre mínima de uma seqüência. O genoma de $P$. falciparum poderia ser percorrido por uma janela deslizante, cujas seqüências seriam analisadas pelo RANDFOLD. Seqüências com energia livre mínima significativas seriam candidatos a novos ncRNAs.

É necessário realizar uma validação biológica dos candidatos a novos ncRNAs em $P$. falciparum. Quando o conjunto de candidatos é pequeno, uma abordagem é realizar experimentos individuais como Northern blot, RT-PCR e 5' e 3' RACE. No entanto, 324 candidatos é um número muito grande para seguir essa estratégia. Neste caso há duas alternativas: diminuir o número de candidatos ou realizar um experimento que verifique a transcrição de todos os candidatos de uma vez, como microarray.

Para diminuir o número de candidatos, uma alternativa é combinar os resultados de várias ferramentas. Por exemplo, RANDFOLD poderia ser usado para analisar apenas as seqüências classificadas como ncRNAs pelo PSoL e/ou pelo eQRNA. Ou ainda, poderia ser escolhido apenas a intersecção de resultados de outras ferramentas de análise comparativa que também classificam alinhamentos,

\footnotetext{
${ }^{3}$ Antes disso, embora as seqüências atuais sejam disponibilizadas por essa instituição, não é permitido realizar análises globais sobre esse genoma.
} 
como o RNAz [281] e o Dynalign [272].

Uma vez que a transcrição de alguns candidatos é detectada, um próximo passo seria a análise de sua função. Para isso, a deleção de cada um desses genes em parasitas transgênicos poderia mostrar alguma alteração de fenótipo. É possível, no entanto, que tal alteração só seja perceptível quando o parasita infecta o hospedeiro. Como os candidatos obtidos neste trabalho são conservados em $P$. yoelii, uma espécie que infecta roedores, experimentos poderiam ser feitos utilizando camundongos infectados com parasitas transgênicos.

A estratégia de análise comparativa aqui descrita está sendo repetida, mas desta vez utilizando as matrizes e parâmetros default do BLAST. Este procedimento tem a finalidade de comparar os resultados utilizando uma abordagem de construção cuidadosa de alinhamentos e uma abordagem mais simplista.

O número de genomas seqüenciados vem aumentando a cada dia, muitos deles de vertebrados. Genomas já disponíveis e outros prestes a serem disponibilizados podem ser utilizados para a identificação de novas seqüências de TERC. A identificação de TERCs em espécies mais distantes filogeneticamente de mamíferos poderia enriquecer os alinhamentos de vertebrados e, assim, permitir a identificação de TERCs ainda mais divergentes. Idealmente, a identificação de TERCs em espécies entre vertebrados e ciliados poderia permitir a construção de um modelo unificado entre eles.

TERCs ainda não foram identificados em plantas. Arabidopsis thaliana é uma espécie que compartilha muitos genes homólogos com Plasmodium, e sua repetição telomérica é igual à repetição mais freqüente em Plasmodium, TAAACCC. Isso pode indicar que a telomerase seja também o mecanismo usado por esta planta para a manutenção de seus telômeros. Essa espécie também poderia ser outro alvo de buscas.

As espécies de Saccharomyces se dividem em três grupos filogenéticos: sensu stricto, sensu lato e petite negative. Somente são conhecidos TERCs do primeiro grupo. Abordagens biológicas de identificação de TERCs em espécies dos demais grupos com base nas seqüencias de sensu stricto falharam provavelmente devido à divergência dos TERCs entre os grupos [168]. De posse agora de um alinhamento de 7 espécies de Saccharomyces sensu stricto, o TERP poderia ser utilizado para fazer uma busca no genoma de Saccharomyces castellii, uma Saccharomyces sensu lato cujo genoma está sendo seqüenciado e já está disponível.

A seleção de pré-candidatos realizada pelo sistema TERP exige um match perfeito entre uma região do genoma e o template telomérico procurado. Isso implica que, se justamente o template do TERC possuir algum erro de seqüenciamento, o TERC não será selecionado como pré-candidato 
e, conseqüentemente, não será identificado ${ }^{4}$. Uma alternativa para diminuir esse efeito é a implementação de uma opção que permita matches imperfeitos durante a seleção de pré-candidatos. O usuário poderia definir uma regra de reconhecimento de padrões onde, por exemplo, permita a substituição de apenas um nucleotídeo em qualquer posição do template.

O TERP poderia evoluir para uma ferramenta mais genérica de inserção de conhecimento de regiões conservadas. O sistema poderia ser ajustado para caracterizar RNAs com não apenas uma região conservada mas com uma combinação de padrões. Várias regiões de conservação poderiam ser definidas para guiar a seleção de pré-candidatos e os ajustes do modelo de covariância.

Além da seleção de pré-candidatos e da modificação do modelo de covariância para reconhecimento de uma região conservada, duas importantes características do sistema são o ajuste do modelo nulo para cada seqüência sendo analisada e o teste de significância de escore. Portanto, o sistema TERP pode também ser aplicado em famílias de RNAs que não possuam uma região de seqüência conservada. Para isso o sistema deve ser adaptado de forma que a seleção de pré-candidatos, ao invés de buscar regiões genômicas contendo uma seqüência específica, seja uma varredura do genoma utilizando uma janela deslizante. O tamanho e o deslocamento dessa janela devem ser parâmetros do sistema. O tamanho da janela deve indicar o tamanho máximo do RNA esperado para a família de interesse.

Outro desafio é a busca por genes de RNA que podem sofrer splicing. O programa cmsearch do INFERNAL possui uma opção para a realização de alinhamentos locais em relação ao modelo (e não apenas à seqüência). Essa opção poderia ser explorada para identificar domínios do RNA de interesse separados por regiões intrônicas.

Durante o desenvolvimento deste trabalho, foi concebida uma idéia de modelagem do problema de identificação de estrutura secundária através de grafos. Uma possível modelagem seria representar cada lado de uma hélice (região de nucleotídeos consecutivos que pareiam com outra região de nucleotídeos consecutivos) como um nó no grafo. Dois tipos de arestas orientadas seriam utilizadas. Um tipo de aresta é usada para indicar a ordem em que os nós ocorrem na seqüência, seguindo a orientação 5 ' $\rightarrow$ 3'. Outro tipo de aresta conecta dois nós se as regiões representadas por eles são lados da mesma hélice, também seguindo a orientação $5^{\prime} \rightarrow 3^{\prime}$. Pseudo-nós podem também ser modelados nessa representação sem a necessidade de um tratamento diferenciado. A figura 6.1 mostra a estrutura secundária de TERCs de ciliados (apenas a sub-estrutura delimitada pela hélice I) utilizando essa representação.

Dada uma estrutura secundária alvo (TERC, por exemplo), construímos um grafo $G_{a}$ desta maneira. Dada uma seqüência $s$ qualquer, é possível construir um grafo $G_{s}$ representando todas as suas

\footnotetext{
${ }^{4}$ Alguns genomas são seqüenciados tendo cobertura de apenas $2 \mathrm{X}$ [82].
} 


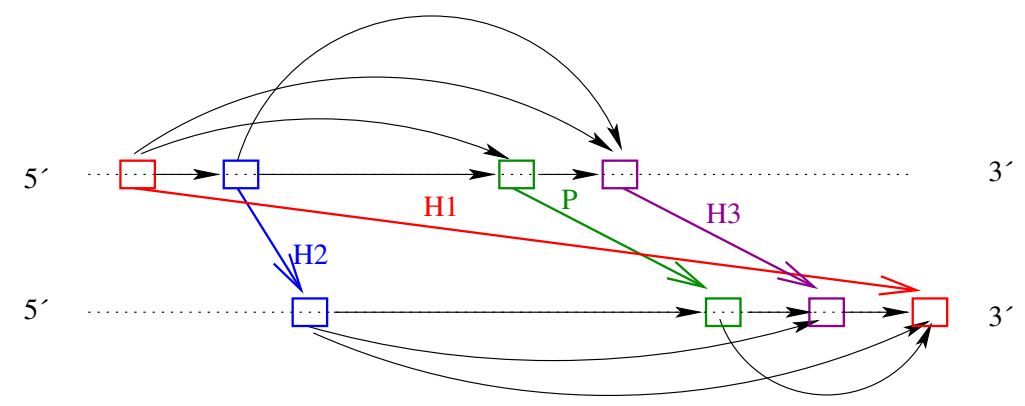

Figura 6.1: Representação em forma de grafo da estrutura secundária de TERC de ciliados para a região delimitada pela hélice 1: hélice 1 (H1), hélice $2(\mathrm{H} 2)$, hélice $3(\mathrm{H} 3)$ e pseudo-nó $(\mathrm{P})$. A parte superior e inferior do grafo correspondem à mesma seqüência na mesma orientação $\left(5^{\prime} \rightarrow 3^{\prime}\right)$. Arestas que conectam nós apenas da parte superior ou inferior são usadas para representar a ordem entre os nós na sequiência, enquanto arestas que cruzam as duas partes são usadas para representar pareamentos. A linha pontilhada não faz parte do grafo, mas apenas faz alusão à seqüência em questão.

possíveis hélices. Desta forma, o problema de identificar se uma estrutura alvo $a$ é topologicamente possível nesta seqüência $s$ é equivalente a procurar um subgrafo de $G_{s}$ isomorfo a $G_{a}$.

Para a implementação de uma busca baseada nesta modelagem, a biblioteca VFLib [262] poderia ser usada. Essa biblioteca implementa algoritmos de isomorfismo de subgrafo. O problema de isomorfismo tem uma alta complexidade de tempo. O algoritmo de Ullman [270], por exemplo, é $O\left(n ! n^{3}\right)$ no pior caso e $O\left(n^{3}\right)$ no melhor caso, onde $n$ é o número de nós dos grafos. A biblioteca VFLib implementa o algoritmo VF2, cuja complexidade de tempo é $O(n ! n)$ no pior caso e $O\left(n^{2}\right)$ no melhor caso [50]. Além disso, enquanto o algoritmo de Ullman ocupa $O\left(n^{3}\right)$ de memória, VF2 ocupa $O(n)$ [262]. Resta saber se, devido à complexidade de tempo de pior caso, para qual tamanho limite de seqüência de RNA seria possível aplicar essa abordagem. 

APÊNDICE A

\section{Glossário}

5' e 3' RACE Os experimentos de 5' e 3' RACE (Rapid Amplification of cDNA Ends) têm como objetivo amplificar as extremidades 5' e 3', respectivamente, de um transcrito. Basicamente, são experimentos baseados em RT-PCR onde, no caso do 5' RACE, é utilizado um primer antisense a uma região conhecida do transcrito para transcrever reversamente (de RNA para DNA) o transcrito dessa região até a extremidade 5'. Após esse primeiro passo, adaptadores com uma seqüência conhecida (poli-C, por exemplo) são colocados nesta extremidade 5' recém copiada a fim de que, na amplificação da fita oposta, um primer sense a este adaptador (poli-G, no caso), possa amplificar o transcrito na outra direção, até o outro primer interno ao transcrito, formando a segunda fita de cDNA. A partir dessa fase inicial, seguem-se etapas tradicionais de PCR, utilizando esses dois primers, do adaptador e da seqüência conhecida ${ }^{1}$. Para obter a extremidade 3', o processo de 3' RACE é realizado de forma equivalente, agora adicionando adaptadores na extremidade 3' do transcrito.

Algoritmos genéticos Um algoritmo genético é uma técnica estocástica usada para encontrar soluções aproximadas para problemas cujo espaço de busca não permita uma análise exaustiva. Portanto, para problemas de RNAs, ele pode ser usado como uma alternativa a algoritmos com uma exigência alta de tempo e memória [193]. O nome é uma alusão à teoria de seleção natural. Um algoritmo genético define indivíduos (soluções possíveis), uma função objetiva que atribui um escore a cada indivíduo, operadores de mutação e de crossover e uma função de seleção. Começando com uma população inicial de indivíduos, o algoritmo cria novos indivíduos a partir de um ou dois indivíduos existentes, chamados pais, através da aplicação dos operadores. O operador de mutação gera um novo indivíduo através da alteração de um pai, enquanto o operador de crossover gera dois novos indivíduos combinando dois pais. Os indivíduos que sobrevivem para a próxima geração (próxima iteração algorítmica) são aqueles que foram melhor avaliados pela função de seleção,

\footnotetext{
${ }^{1} \mathrm{Na}$ verdade, um primer mais interno ao primer conhecido anteriormente é utilizado nesta fase.
} 
utilizando os escores atribuídos pela função objetiva. Em geral, o algoritmo encerra sua execução após um número pré-definido de gerações ou quando o escore agregado da população não é mais incrementado de uma geração para a outra.

Análise sintática Dada uma gramática $G$, a análise sintática de uma seqüência $s$ consiste no cálculo de todas as derivações possíveis de $s$ de acordo com $G$, onde cada derivação é formada pelo conjunto de regras de $G$ usadas para reconhecer $s$ [2].

Analisadores sintáticos Um analisador sintático para uma gramática $G$ é um programa que realiza a análise sintática de seqüências de entrada. Se a gramática $G$ é estocástica, o analisador também calcula a probabilidade da seqüência sendo analisada de acordo com a gramática $G$.

Árvores Uma árvore é um tipo especial de grafo onde, brevemente, cada nó é conectado a apenas um nó pai e a zero ou mais nós filhos. Tanto nós quanto arestas podem possuir atributos ou pesos.

Grafos Um grafo $G$ é um conjunto $G=\{N, A\}$ onde $N$ é um conjunto de nós (ou vértices) e $A$ é um conjunto de arestas que conectam esses nós. As arestas podem possuir pesos. Um grafo $G^{\prime}=\left\{N^{\prime}, E^{\prime}\right\}$ é um subgrafo de $G$ se $N^{\prime} \in N$ e $E^{\prime} \in E[51]$.

\section{Gramáticas Veja Gramáticas Livres de Contexto Estocásticas.}

Gramáticas Livres de Contexto Estocásticas Gramáticas são usadas em Linguagens Formais para representar linguagens, ou seja, conjuntos de seqüências. Desta forma, conjuntos de seqüências biológicas, como RNAs, podem ser representados por gramáticas. [245]. Uma gramática é composta por um conjunto de regras que descrevem as seqüências. Estas regras podem possuir atributos, como valores termodinâmicos ou probabilísticos. Quando os atributos são probabilísticos, a gramática é estocástica. Em uma gramática livre de contexto, as regras podem representar dependências encaixadas de distâncias arbitrárias, e portanto são úteis para descrever pareamentos entre bases de um RNA.

\section{Gramáticas Livres de Contexto Estocásticas de Pares Uma gramática livre de contexto} estocástica de pares representa, ao invés de seqüências, alinhamentos pairwise de seqüências.

Informação mútua $\mathrm{O}$ conteúdo de informação mútua de duas variáveis aleatórias mostra o quanto estas variáveis estão correlacionadas [188]. Formalmente, a informação mútua $I$ das va- 
riáveis aleatórias $X$ e $Y$ é dada pela equação $I(X, Y)=\sum_{x \in X} \sum_{y \in Y} p(x, y) \lg \frac{p(x, y)}{p(x) p(y)}$ Assim, se $X$ e $Y$ são independentes, $I(X, Y)=0$, pois neste caso $p(x, y)=p(x) p(y)$.

Modelo Oculto de Markov Um modelo oculto de Markov é um modelo estatístico para modelar processos de Markov. Pode ser visto como um caso particular de gramáticas regulares estocásticas que, por formarem uma classe de gramáticas mais restritas que a das gramáticas livres de contexto, apresentam menor complexidade de análise sintática. Esses modelos também são utilizados para modelar seqüências [73], mas são inadequados para modelar estruturas secundárias.

Modelo Oculto de Markov de Pares Um modelo oculto de Markov de pares representa, ao invés de seqüências, alinhamentos pairwise de seqüências.

Monte Carlo Uma simulação computacional é um programa que procura tirar conclusões sobre o comportamento de um sistema testando um modelo desse sistema. Testar todas as configurações de um sistema é freqüentemente impossível ou proibitivo, o que exige a geração de amostras de configurações. Uma simulação de Monte Carlo é uma simulação computacional estocástica, utilizando números aleatórios (ou pseudo-aleatórios) para amostrar as configurações do sistema [173].

Northern blot $\mathrm{O}$ experimento de Northern blot visa detectar a existência de determinados transcritos e seus tamanhos em uma amostra. Neste experimento, uma amostra de RNAs é adicionada a um gel (como de agarose ou poliacrilamida). Um campo elétrico é aplicado a este gel a fim de que os RNAs migrem para uma das extremidades do gel com velocidade proporcional ao seu tamanho. Uma seqüência antisense à um trecho da seqüência alvo é marcada radioativamente (sonda) e hibridizada contra o gel. Se a seqüência de RNA alvo estiver no gel, ela vai se hibridizar com a sonda, que então poderá ser detectada no gel. A altura do gel em que o RNA foi detectado indica o tamanho de sua seqüência.

Processo de Markov Um processo de Markov é uma família de variáveis aleatórias $X_{t}: t \in T$ indexadas pelo tempo $t$, onde o valor de $X_{t+1}$ depende apenas do valor de $X_{t}$. Ou seja, um processo onde o próximo resultado depende apenas do resultado atual.

Programação dinâmica Programação dinâmica é um método para resolver problemas de otimização, isto é, problemas cujo objetivo é encontrar uma solução ótima que representa o valor máximo ou mínimo baseado em um sistema de escore. Esta técnica pode ser aplicada quando a solução ótima puder ser calculada a partir de soluções ótimas de partes do problema original. Soluções de sub-problemas são armazenadas em uma tabela, evitando recálculos desnecessários [51, 78]. 
RT-PCR O experimento de Reverse transcriptase Polimerase Chain Reaction (RT-PCR) produz e amplifica cópias de DNA a partir de seqüências de RNAs. Utilizando dois primers para a seqüência alvo, um sense (na porção 5') e outro antisense (na porção 3'), a seqüência amplificada consiste na região delimitada por esses dois primers.

Simulated annealing Simulated annealing é uma técnica de otimização que procura encontrar um mínimo global de uma função custo que pode possuir vários mínimos locais. O algoritmo básico é uma alusão ao processo de aquecimento de um material sólido e resfriamento lento do mesmo, de forma a alcançar configurações moleculares de energia interna inferior à original [15].

\section{Subgrafos Ver grafos.}

Support Vector Machines Support vector machines (SVMs) são um conjunto de métodos de aprendizado computacional usados para classificação e regressão (análise de relacionamentos entre variáveis aleatórias) [10]. Estes métodos criam funções a partir de amostras de treinamentos. Essas funções podem ser um classificador ou uma função geral de regressão.

Weight matrices Uma weight matrix é uma matriz $M_{n \times l}$ usada para modelar padrões de tamanho $l$ formados por símbolos de um alfabeto de tamanho $n$. Cada posição $M_{i j}$ possui um escore para a ocorrência do símbolo $i$ na posição $j$ do padrão. Quando esses escores são valores de probabilidade, devem ser números entre 0 e 1 e a soma de cada coluna deve ser igual a 1 . No caso de seqüências de nucleotídeos, pode então ser usada para modelar a distribuição de nucleotídeos em cada posição de um motivo. 
APÊNDICE B

\section{Abreviaturas}

bp - pares de base (base pairs)

ELM - energia livre mínima

Gb - Giga bases (1 Gb = 1000000000 bases)

GLCE - gramática livre de contexto estocástica

GLCEP - gramática livre de contexto estocástica de pares

HMM - hidden Markov model (modelo oculto de Markov)

$\mathrm{Kb}$ - Kilo bases ( $1 \mathrm{~Kb}=1000$ bases)

$\mathrm{Mb}$ - Mega bases (1 Mb $=1000000$ bases)

miRNA - micro RNA

nt - nucleotídeos

ncRNA - RNA não codificante (non coding $R N A$ )

snoRNA - pequeno RNA nucleolar (small nucleolar RNA)

snRNA - pequeno RNA nuclear (small nuclear RNA)

SVM - Support Vector Machine

TERC - componente RNA da telomerase (Telomerase RNA Component)

TERP - preditor de RNAs telomerase (Telomerase RNA Predictor)

TERT - Transcriptase Reversa da Telomerase (Telomerase Reverse Transcriptase)

tmRNA - RNA transportador-mensageiro (transfer-messenger RNA)

tRNA - RNA transportador (transfer RNA) 

APÊNDICE C

\section{Tabela de programas e serviços WEB para pesquisa de ncRNAs}


Tabela C.1: Programas disponíveis e servidores web para predição de estrutura secundária.

\begin{tabular}{|c|c|}
\hline Método & URL \\
\hline \multicolumn{2}{|l|}{$A b$ initio } \\
\hline CONTRAfold [67] & http://contra.stanford.edu/contrafold/ \\
\hline HotKnots [215] & http://www.cs.ubc.ca/labs/beta/Software/HotKnots/ \\
\hline ILM $[226,225]$ & http://cic.cs.wustl.edu/RNA/ \\
\hline Kinfold [87] & http://www.tbi.univie.ac.at/ xtof/RNA/Kinfold \\
\hline MFOLD $[302,299,300]$ & http://www.bioinfo.rpi.edu/applications/mfold/ \\
\hline MWM) $[258]$ & ftp://ftp.cshl.org/pub/science/mzhanglab/tabaska/ \\
\hline NUPACK $[65,66]$ & http://www.acm.caltech.edu/ niles/software.html \\
\hline PKNOTS $[218]$ & http://selab.janelia.org/software \\
\hline pknotsRG $[242,210]$ & http://bibiserv.techfak.uni-bielefeld.de/pknotsrg/ \\
\hline RNAfold [114] & http://www.tbi.univie.ac.at/ ivo/RNA/ \\
\hline RDfolder [295] & http://rna.cbi.pku.edu.cn/ \\
\hline RNAKinetics [57] & http://bioinf.fbb.msu.ru/RNA/kinetics/ \\
\hline RNALOSS $[44,45]$ & http://clavius.bc.edu/ clotelab/RNALOSS/ \\
\hline RNAshapes $[252,276]$ & http://bibiserv.techfak.uni-bielefeld.de/rnashapes/ \\
\hline RNASTRUCTURE [175] & http://rna.urmc.rochester.edu \\
\hline RNAsubopt [291] & http://www.tbi.univie.ac.at/ ivo/RNA \\
\hline Sfold $[64,63,32]$ & http://sfold.wadsworth.org/index.pl \\
\hline \multicolumn{2}{|l|}{ Comparativos } \\
\hline BayesFold [140] & http://jaynes.colorado.edu/Bayes/ \\
\hline Bouthinon et.al. [22] & available upon request \\
\hline CARNAC $[266]$ & http://bioinfo.lifl.fr/carnac \\
\hline COFOLGA $[260]$ & available upon request \\
\hline comRNA [129] & http://ural.wustl.edu/ yji/comRNA/ \\
\hline Consan $[70]$ & http://selab.wustl.edu/people/robin/consan \\
\hline ConStruct $[165]$ & http://www.biophys.uni-duesseldorf.de/local/ConStruct \\
\hline Dynalign $[176,174]$ & http://rna.urmc.rochester.edu \\
\hline FOLDALIGN $[107]$ & http://foldalign.kvl.dk \\
\hline ILM $[226,225]$ & http://cic.cs.wustl.edu/RNA/ \\
\hline MARNA [248] & http://biwww2.informatik.uni-freiburg.de/Software \\
\hline MWM $[258]$ & ftp://ftp.cshl.org/pub/science/mzhanglab/tabaska/ \\
\hline Pfold $[141,142]$ & http://www.daimi.au.dk/ compbio/rnafold/ \\
\hline PMComp/PMMulti [115] & http://www.tbi.univie.ac.at/ ivo/RNA/PMcomp/ \\
\hline RAGA/PRAGA [193] & http://igs-server.cnrs-mrs.fr/ cnotred/ \\
\hline RNAalifold [116] & http://www.tbi.univie.ac.at/ ivo/RNA/ \\
\hline RNA_align [130] & http://www.csd.uwo.ca/ bma/rna_align \\
\hline RNA-Decoder [201] & http://www.ebi.ac.uk/ meyer/rnadecoder/ \\
\hline RNAforester [112] & http://bibiserv.techfak.uni-bielefeld.de/rnaforester \\
\hline RNAGA [34] & ftp://ftp.ncifcrf.gov/pub/users/chen/rnaga.tar.Z \\
\hline RNAscf [7] & available upon request \\
\hline Stemloc [118] & http://biowiki.org \\
\hline SLASH $[97]$ & http://www.bioinf.au.dk/slash \\
\hline X2 [132] & http://tyrant.ucsc.edu/X2s \\
\hline
\end{tabular}


Tabela C.2: Programas disponíveis e servidores web para comparação estrutural e identificação de ncRNAs.

\begin{tabular}{|c|c|}
\hline Método & URL \\
\hline \multicolumn{2}{|l|}{$\begin{array}{l}\text { Comparação } \\
\text { estrutural }\end{array}$} \\
\hline MiGal [4] & http://igm.univ-mlv.fr/ allali/migal/ \\
\hline RAG database [92] & http://monod.biomath.nyu.edu/rna \\
\hline RNAdistance [117] & http://www.tbi.univie.ac.at/ ivo/RNA \\
\hline RNAMute [43] & http://www.cs.bgu.ac.il/ RNAMute/ \\
\hline RNApdist [19] & http://www.tbi.univie.ac.at/ ivo/RNA \\
\hline \multicolumn{2}{|l|}{$\begin{array}{l}\text { Identificação } \\
\text { de ncRNAs }\end{array}$} \\
\hline \multicolumn{2}{|l|}{ Gerais } \\
\hline NCRNASCAN [219] & http://selab.janelia.org/software \\
\hline RANDFOLD [20] & http://bioinformatics.psb.ugent.be/software.php \\
\hline RNAplfold/RNALfold [13] & http://www.tbi.univie.ac.at/ ivo/RNA \\
\hline ddbRNA $[61]$ & http://www.tigem.it/Research/Personal\%20Web\%20Page_files/dibernardo/links.htm \\
\hline Dynalign [272] & http://rna.urmc.rochester.edu \\
\hline EQRNA $[220,217]$ & http://selab.janelia.org/software \\
\hline MSARI [53] & http://theory.csail.mit.edu/MSARi \\
\hline Rfam database $[100,101]$ & http://rfam.wustl.edu \\
\hline RNAZ [281] & http://www.tbi.univie.ac.at/simwash/RNAz \\
\hline \multicolumn{2}{|l|}{ Treináveis } \\
\hline INFERNAL [76] & http://selab.janelia.org/software \\
\hline RNACAD [25] & http://www.cse.ucsc.edu/ mpbrown/rnacad \\
\hline RSEARCH [138] & http://selab.janelia.org/software \\
\hline \multicolumn{2}{|l|}{ Família-específicos } \\
\hline ARAGORN $[151]$ & http://bioinfo.thep.lu.se \\
\hline miralign [279] & http://166.111.201.26/miralign \\
\hline $\operatorname{mirScan}[156]$ & http://genes.mit.edu/mirscan \\
\hline miRseeker [149] & http://www.fruitfly.org/seq_tools/miRseeker.html \\
\hline ProMirII [190] & http://cbit.snu.ac.kr/ ProMiR2 \\
\hline RNAmicro $[110]$ & http://www.bioinf.uni-leipzig.de/Software \\
\hline snoscan $[163,236]$ & http://lowelab.ucsc.edu/snoscan \\
\hline snoGPS $[237,236]$ & http://lowelab.ucsc.edu/snoGPS \\
\hline tRNAscan-SE [162] & http://lowelab.cse.ucsc.edu/tRNAscan-SE \\
\hline
\end{tabular}





\section{Referências Bibliográficas}

[1] Abrahams, J. P., van den Berg, M., van Batenburg, E., And Pleij, C. Prediction of RNA secondary structure, including pseudoknotting, by computer simulation. Nucleic Acids Research 18, 10 (1990), 3035-3044.

[2] Aho, A. V., And Ullman, J. D. The Theory of Parsing, Translation, and Compiling, vol. 1: Parsing. Prentice-Hall, Inc., Englewood Cliffs,NJ, 1972.

[3] Akmaev, V. R., Kelley, S. T., And Stormo, G. D. Phylogenetically enhanced statistical tools for RNA structure prediction. Bioinformatics 16, 6 (2000), 501-512.

[4] Allali, J., And Sagot, M. F. A new distance for high level RNA secondary structure comparison. Transactions on Computational Biology and Bioinformatics 2, 1 (2005), 3-14.

[5] Altschul, S. F., And Gish, W. Local alignment statistics. Methods in Enzymology 266 (1996), 460-480.

[6] Artandi, S. E. Telomeres, telomerase, and human disease. New England Journal of Medicine 355, 12 (2006), 1195-1197.

[7] Bafna, V., Tang, H., And Zhang, S. Consensus folding of unaligned RNA sequences revisited. Journal of Computational Biology 13, 2 (2006), 283-295.

[8] Bafna, V., And Zhang, S. FastR: Fast database search tool for non-coding RNA. Proceedings of the 2004 IEEE Computational Systems Bioinformatics Conference (CSB2004) (2004).

[9] Bahl, A., Brunk, B., Coppel, R. L., Crabtree, J., Diskin, S. J., Fraunholz, M. J., Grant, G. R., Gupta, D., Huestis, R. L., Kissinger, J. C., Labo, P., Li, L., McWeeney, S. K., Milgram, A. J., Roos, D. S., Schug, J., And Stoeckert, C. J. J. PlasmoDB: the Plasmodium genome resource. Nucleic Acids Research 30, 1 (2002), 87-90. 
[10] Baldi, P., And Brunak, S. Bioinformatics: The Machine Learning Approach. MIT Press, 2001. Capítulo 11.

[11] Barash, D. Second eigenvalue of the Laplacian matrix for predicting RNA conformational switch by mutation. Bioinformatics 20, 12 (2004), 1861-1869.

[12] BAss, H. W. Telomere dynamics unique to meiotic prophase: formation and significance of the bouquet. Cellular and Molecular Life Sciences 60 (2003), 2319-2324.

[13] Bernhart, S. H., Hofacker, I. L., And Stadler, P. F. Local RNA base pairing probabilities in large sequences. Bioinformatics 22, 5 (2006), 614-615.

[14] Berry, A. E., Gardner, M. J., Caspers, G. J., Roos, D. S., and Berriman, M. Curation of the Plasmodium falciparum genome. Trends in Parasitology 20, 12 (2004), 548552.

[15] Bertsimas, D., And Tsitsiklis, J. Simulated annealing. Statiscal Science 8, 1 (1993), $10-15$.

[16] Blackburn, E. H. Telomerase, 1993. In: The RNA World. Cold Spring Harbor Laboratory Press.

[17] Blackburn, E. H. The end of the DNA line. Nature Structural Biology 7, 10 (2000), 847-850.

[18] Blencowe, B. J. Transcription: surprising role for an elusive small nuclear RNA. Current Biology 12 (2002), R147-R149.

[19] Bonhoeffer, S., McCaskill, J. S., Stadler, P. F., And Schuster, P. RNA multistructure landscapes - a study based on temperature dependent partition functions. European biophysics journal 22, 1 (1993), 13-24.

[20] Bonnet, E., Wuyts, J., Rouze, P., And de Peer, Y. V. Evidence that microRnA precursors, unlike other non-coding RNAs, have lower folding free energies than random sequences. Bioinformatics 20, 17 (2004), 2911-2917.

[21] Bottius, E., Bakhsis, N., And Scherf, A. Plasmodium falciparum telomerase: de novo telomere addition to telomeric and nontelomeric sequences and role in chromosome healing. Molecular and Cellular Biology 18, 2 (1998), 919-925.

[22] Bouthinon, D., And Soldano, H. A new method to predict the consensus secondary structure of a set of unaligned RNA sequences. Bioinformatics 15, 10 (1999), 785-798. 
[23] Broad Institute. http://www.broad.mit.edu/.

[24] Brown, J. W. The ribonuclease P database. Nucleic Acids Research 27, 1 (1999), 314.

[25] Brown, M. P. S. Small subunit ribosomal RNA modeling using stochastic context-free grammars. Proceedings of the International Conference on Intelligent Systems for Molecular Biology 8 (2000), 57-66.

[26] Brown, M. P. S., AND Wilson, C. RNA pseudoknot modeling using intersections of stochastic context free grammars with applications to database search. Pacif Symposium on Biocomputing (1996), 109-125.

[27] Brown, T. A. Genomes 2, cap. 13. Wiley-Liss, 2002.

[28] Cano, M. I., Dungan, J. M., Agabian, N., and Blackburn, E. H. Telomerase in kinetoplastid parasitic protozoa. Proceedings of the National Academy of Sciences 96, 7 (1999), $3616-3621$.

[29] Carlton, J. M., Angiuoli, S. V., Suh, B. B., Kooij, T. W., PerteaA, M., Silva, J. C., Ermolaeva, M. D., Allen, J. E., Selengut, J. D., Koo, H. L., Peterson, J. D., Pop, M., Kosack, D. S., Shumway, M. F., Bidwell, S. L., Shallom, S. J., van Aken, S. E., Riedmuller, S. B., Feldblyum, T. V., Cho, J. K., Quackenbush, J., Sedegah, M., Shoaibi, A., Cummings, L. M., Florens, L., Yates, J. R., Raine, J. D., Sinden, R. E., Harris, M. A., Cunningham, D. A., Preiser, P. R., Bergman, L. W., Vaidya, A. B., van Lin, L. H., Janse, C. J., Waters, A. P., Smith, H. O., White, O. R., Salzberg, S. L., Venter, J. C., Fraser, C. M., Hoffman, S. L., Gardner, M. J., And Carucci, D. J. Genome sequence and comparative analysis of the model rodent malaria parasite Plasmodium yoelii yoelii. Nature 419 (2002), 512-519.

[30] Cech, T. R. Beginning to understand the end of the chromossome. Cell 116 (2004), 273-279.

[31] Chakhparonian, M., And Wellinger, R. J. Telomere maintenence and DNA replication: how closely are these two connected? Trends in Genetics 19, 8 (2003), 439-446.

[32] Chan, C. Y., Lawrence, C. E., And Ding, Y. Structure clustering features on the Sfold web server. Bioinformatics 21, 20 (Chan2005), 3926-3928.

[33] Chapon, C., Cech, T. R., And Zaug, A. J. Polyadenylation of telomerase RNA in budding yeast. $R N A$ 3, 11 (1997), 1337-1351. 
[34] Chen, J. H., Le, S. Y., And Maizel, J. V. Prediction of common secondary structures of RNAs: a genetic algorithm approach. Nucleic Acids Research 28, 4 (2000), 991-999.

[35] Chen, J. L., Blasco, M. A., And Greider, C. W. Secondary structure of vertebrate telomerase RNA. Cell 100 (2000), 503-514.

[36] Chen, J. L., And Greider, C. W. Determinants in mammalian telomerase RNA that mediate enzyme processivity and cross-species incompatibility. The EMBO Journal 22, 2 (2003), 304-314.

[37] Chen, J. L., And Greider, C. W. Template boundary definition in mammalian telomerase. Genes \& Development 17, 22 (2003), 2747-2752.

[38] Chen, J. L., And Greider, C. W. An emerging consensus for telomerase RNA structure. Proceedings of the National Academy of Sciences 101, 41 (2004), 14683-14684.

[39] Chen, J. L., And Greider, C. W. Functional analysis of the pseudoknot structure in human telomerase RNA. Proceedings of the National Academy of Sciences 102, 23 (2005), $8080-8085$.

[40] Chen, S. J., And Dill, K. A. RNA folding energy landscapes. Proceedings of the National Academy of Sciences 97, 2 (2000), 646-651.

[41] Chiang, D., And Joshi, A. K. Formal grammars for estimating partition functions of double-stranded chain molecules. Proceedings of HLT 2002, San Diego, March (2002), 63-67.

[42] Chow, J. C., Yen, Z., Zieche, S. M., And Brown, C. J. Silencing of the mammalian X chromosome. Annual Review of Genomics and Human Genetics 6 (2005), 69-92.

[43] Churkin, A., And Barash, D. RNAmute: RNA secondary structure mutation analysis tool. BMC Bioinformatics 7, 221 (2006).

[44] Clote, P. An efficient algorithm to compute the landscape of locally optimal RNA secondary structures with respect to the Nussinov-Jacobson energy model. Journal of Computational Biology 12, 1 (2005), 83-101.

[45] Clote, P. RNALOSS: a web server for RNA locally optimal secondary structures. Nucleic Acids Research 33 (2005), 600-604.

[46] Clote, P., Ferre, F., Kranakis, E., And Krizanc, D. Structural RnA has lower folding energy than random RNA of the same dinucleotide frequency. $R N A 11$ (2005), 578-591. 
[47] Swat and crossmatch - sequence alignment tools. www.genome.washington.edu/uwgc/analysistools/swat.cfm.

[48] Cole, J. R., Chai, B., Marsh, T. L., Farris, R. J., Wang, Q., Kulam, S. A., Chandra, S., McGarell, D. M., Schmidt, T. M., Garrity, G. M., and Tiedje, J. M. The Ribosomal Database Project (RDP-II): previewing a new autoaligner that allows regular updates and the new prokaryotic taxonomy. Nucleic Acids Research 31, 1 (2003), 442-443.

[49] Corda, Y., Schramke, V., Longhese, M. P., Smokvina, T., Paciotti, V., Brevet, V., Gilson, E., AND GÉLI, V. Interaction between set1p and checkpoint protein mec3p in DNA repair and telomere functions. Nature Genetics 21 (1999), 204-208.

[50] Cordella, L. P., Foggia, P., Sansone, C., And Vento, M. Performance evaluation of the VF graph matching algorithm. Proc. of the 10th ICIAP, IEEE Computer Society Press 2 (1999), 1038-1041.

[51] Cormen, T. H., Leiserson, C. E., And Rivest, R. L. Introduction to Algorithms. Mit Press, 1990.

[52] Costa, F. F. Non-coding RNAs: new players in eukaryotic biology. Gene 357 (2005), 83-94.

[53] Coventry, A., Kleitman, D. J., And Berger, B. MSARI: multiple sequence alignments for statistical detection of RNA secondary structure. Proceedings of the National Academy of Sciences 101, 33 (2004), 12102-12107.

[54] Cunningham, D. D., And Collins, K. Biological and biochemical functions of RNA in the Tetrahymena telomerase holoenzyme. Molecular and Cellular Biology 25, 11 (2005), 44424454 .

[55] Cupal, J., Hofacker, I. L., and Stadler, P. F. Dynamic programming algorithm for the density of states of RNA secondary structures. Computer Science and Biology 96 (1996), 184-186.

[56] Dandjinou, A. T., Lévesque, N., Larose, S., Lucier, J. F., Elela, S. A., And Wellinger, R. J. A phylogenetically based secondary structure for the yeast telomerase RNA. Current Biology 14, 13 (2004), 1148-1158.

[57] Danilova, L. V., Pervouchine, D. D., Favorov, A. V., And Mironov, A. A. RnAKINETICS: a web server that models secondary structure kinetics of an elongating RNA. Journal of Bioinformatics and Computational Biology 4, 2 (2006), 589-596. 
[58] Dassanayake, R. S., Chandrasekharan, N. V., and Karunanayake, E. H. Transspliced leader RNA, 5S-rRNA genes and novel variant orphan spliced-leader of the lymphatic filarial nematode Wuchereria bancrofti, and a sensitive polymerase chain reaction based detection assay. Gene 269 (2001), 185-193.

[59] De Novoa, P. G., And Williams, K. P. The tmRNA website: reductive evolution of tmRNA in plastids and other endosymbionts. Nucleic Acids Research 32 (2004), D104-D108.

[60] del Portillo, H. A., Fernandez-Becerra, C., Bowman, S., Oliver, K., Preuss, M., Sanchez, C. P., Schneider, N. K., Villalobos, J. M., Rajandream, M. A., Harris, D., Silva, L. H. P., Barrell, B., And Lanzer, M. A superfamily of variant genes encoded in the subtelomeric region of Plasmodium vivax. Nature 410 (2001), 839-842.

[61] Di Bernardo, D., Down, T., And Hubbard, T. ddbRNA: detection of conserved secondary structures in multiple alignments. Bioinformatics 19, 13 (2003), 1606-1611.

[62] Ding, Y. Statistical and bayesian approaches to RNA secondary structure prediction. $R N A$ 12 (2006), 323-331.

[63] Ding, Y., Chan, C. Y., And Lawrence, C. E. Sfold web server for statistical folding and rational design of nucleic acids. Nucleic Acids Research 32, Web server issue (2004), W135-W141.

[64] Ding, Y., And Lawrence, C. E. A statistical sampling algorithm for RNA secondary structure prediction. Nucleic Acids Research 31, 24 (2003), 7280-7301.

[65] Dirks, R. M., And Pierce, N. A. A partition function algorithm for nucleic acids secondary structure including pseudoknots. Journal of Computational Chemistry 24, 13 (2003), 16641677.

[66] Dirks, R. M., And Pierce, N. A. An algorithm for computing nucleic acid base-pairing probabilities including pseudoknots. Journal of Computational Chemistry 25 (2004), 12951304.

[67] Do, C. B., Woods, D. A., And Batzoglou, S. CONTRAfold: RNA secondary structure prediction without physics-based models. Bioinformatics 22, 14 (2006), e90-e98.

[68] Dong, S., And Searls, D. B. Gene structure prediction by linguistic methods. Genomics 23 (1994), 540-551. 
[69] Dowell, R. D. RNA structural alignment using stochastic context-free grammars, 2004. Ph.D. Thesis.

[70] Dowell, R. D., ANd Eddy, S. R. Efficient pairwise RNA structure prediction and alignment using sequence alignment constraints. BMC Bioinformatics 2006, 7:400 7:400 (2006).

[71] Durbin, R., Eddy, S. R., Krogh, A., and Mitchison, G. Biological Sequence Analysis: Probabilistic Models of Proteins and Nucleic Acids. Cambridge University Press, 1998.

[72] Eddy, S. E. Maximum likelihood of extreme value distributions, 1997. http://selab.janelia.org/publications/Eddy97b/Eddy97b-techreport.pdf.

[73] Eddy, S. R. Hidden markov models. Current Opinion in Structural Biology 6 (1996), 361365.

[74] EDDy, S. R. Non-coding RNA genes and the modern RNA world. Nature Reviews 2 (2001), 919-929.

[75] Eddy, S. R. Computational genomics of noncoding RNA genes. Cell 109 (2002), 137-140.

[76] EDDY, S. R. A memory-efficient dynamic programming algorithm for optimal alignment of a sequence to an RNA secondary structure. BMC Bioinformatics 3, 1 (2002), 18.

[77] EDDY, S. R. How do RNA folding algorithms work? Nature Biotechnology 22, 11 (2004), $1457-1458$.

[78] EdDY, S. R. What is dynamic programming? Nature Biotechnology 22, 7 (2004), 909-910.

[79] EDdy, S. R. Where did the BLOSUM62 alignment score matrix come from? Nature Biotechnology 22, 8 (2004), 1035-1036.

[80] Eddy, S. R., ANd Durbin, R. RNA sequence analysis using covariance models. Nucleic Acids Research (1994), 2079-2088.

[81] Eichler, E. E., And SAnkoff, D. Structural dynamics of eukaryotic chromosome evolution. Science 301 (2003), 793-797.

[82] Ensembl Genome Browser. http://www.ensembl.org/.

[83] Ferre-D'Amare, A. R., Zhou, K., And Doudna, J. A. Crystal structure of a hepatitis delta virus ribozyme. Nature 395 (1998), 567-574. 
[84] Fichant, G. A., And Burks, C. Identifying potential tRNA genes in genomic DNA sequences. Journal of Molecular Biology 220 (1991), 659-671.

[85] Figueiredo, L. M., Rocha, E. P., Mancio-Silva, L., Prevost, C., HernandezVerdun, D., And Scherf, A. The unusually large Plasmodium telomerase reversetranscriptase localizes in a discrete compartment associated with the nucleolus. Nucleic Acids Research 33, 3 (2005), 1111-1122.

[86] Filipowicz, W. Imprinted expression of small nucleolar RNAs in brain: time for RNomics. Proceedings of the National Academy of Sciences 97, 26 (2000), 14035-14037.

[87] Flamm, C., Fontana, W., Hofacker, I. L., And Schuster, P. RNA folding at elementary step resolution. RNA 6 (2000), 325-338.

[88] Forstemann, K., And Lingner, J. Telomerase limits the extent of base pairing between template RNA and telomeric DNA. EMBO reports 6, 4 (2005), 361-366.

[89] Fragnet, L., Blasco, M. A., Klapper, W., and Rasschaert, D. The RNA subunit of telomerase is encoded by Marek's disease virus. Journal of Virology 77, 10 (2003), 5985-5996.

[90] G., H. D., D., T. J., AND J., G. T. Using CLUSTAL for multiple sequence alignments. Methods in Enzymology 266 (1996), 383-402.

[91] Gall, J. G. Beginning of the end: origins of the telomere concept, 1995. In: Telomeres. Cold Spring Harbor Laboratory Press.

[92] Gan, H. H., Fera, D., Zorn, J., Shiffeldrim, N., Tang, M., Laserson, U., Kim, N., AND SCHLICK, T. RAG: RNA-As-Graphs database - concepts, analysis, and features. Bioinformatics 20, 8 (2004), 1285-1291.

[93] Gardner, M. J., Hall, N., Fung, E., White, O., Berriman, M., Carlton, R. W., Pain, A., Nelson, K. E., Bowman, S., Paulsen, I. T., James, K., Eisen, J. A., Rutherford, K., Salzberg, S. L., Craig, A., Kyes, S., Chan, M. S., Nene, V., Shallom, S. J., Suh, B., Peterson, J., Angiuoli, S., Pertea, M., Allen, J., Selengut, J., Haft, D., Mather, M. W., Vaidya, A. B., Martin, D. M. A., Fairlamb, A. H., Fraunholz, M. J., Roos, D. S., Ralph, S. A., McFadden, G. I., Cummings, L. M., Subramanian, G. M., Mungall, C., Venter, J. C., Carucci, D. J., Hoffman, S. L., Newbold, C., Davis, R. W., Fraser, C. M., and Barrell, B. Genome sequence of the human malaria parasite Plasmodium falciparum. Nature 419 (2002), 498-511. 
[94] Genbank. http://www.ncbi.nlm.nih.gov/Genbank/.

[95] Gilbert, S. D., And Batey, R. T. Riboswitches: fold and function. Chemistry \& Biology 13 (2006), 805-807.

[96] Gorodkin, J., Heyer, L. J., And Stormo, G. D. Finding the most significant common sequence and structure motifs in a set of RNA sequences. Nucleic Acids Research 25, 18 (1997), 3724-3732.

[97] Gorodkin, J., Stricklin, S. L., and Stormo, G. D. Discovering common stem-loop motifs in unaligned RNA sequences. Nucleic Acids Research 29, 10 (2001), 2135-2144.

[98] Greider, C. Telomerase biochemistry and regulation, 1995. In: Telomeres. Cold Spring Harbor Laboratory Press.

[99] Griffiths-Jones, S. RALEE - RNA ALignment Editor in Emacs. Bioinformatics 21 (2005), 257-259.

[100] Griffiths-Jones, S., Bateman, A., Marshall, M., Khanna, A., And Eddy, S. R. Rfam: an RNA family database. Nucleic Acids Research 31, 1 (2003), 439-441.

[101] Griffiths-Jones, S., Moxon, S., Marshall, M., Khanna, A., Eddy, S. R., And Bateman, A. Rfam: annotating non-coding RNAs in complete genomes. Nucleic Acids Research 33 (2005), D121-D124.

[102] Gulko, B., And Haussler, D. Using multiple alignment and phylogenetic trees to detect RNA secondary structure. Pacific Symposium on Biocomputing (1996), 350-367.

[103] Gunasekera, A. M., Patankar, S., Schug, J., Eisen, G., Kissinger, J., Roos, D., AND Wirth, D. F. Widespread distribution of antisense transcripts in the Plasmodium falciparum genome. Molecular \& Biochemical Parasitology 136 (2004), 35-42.

[104] Haebel, P., Gutmann, S., And Ban, N. Dial tm for rescue: tmRnA engages ribosomes stalled on defective mRNAs. Current Opinion in Structural Biology 14 (2004), 58-65.

[105] Hall, N., And Carlton, J. Comparative genomics of malaria parasites. Current Opinion in Genetics 6 Development 15 (2005), 609-613.

[106] Hannon, G. J. RNA interference. Nature 418 (2002), 244-251. 
[107] Havgandd, J. H., Lyngso, R., Stormo, G. D., And Gorodkin, J. Pairwise local structural alignment of RNA sequences with sequence similarity less than $40 \%$. Bioinformatics 21, 9 (2005), 1815-1824.

[108] He, L., And Hannon, G. J. MicroRNAs: small RNAs with a big role in gene regulation. Nature Reviews Genetics 5, 7 (2004), 522-531.

[109] Henderson, E. Telomere DNA structure, 1995. In: Telomeres. Cold Spring Harbor Laboratory Press.

[110] Herbel, J., ANd Stadler, P. F. Hairpins in a haystack: recognizing microRNA precursors in comparative genomics data. Bioinformatics 22, 14 (2006), 197-202.

[111] Higgs, P. G. RNA secondary structure: physical and computational aspects. Quaterly Reviews of Biophysics 33, 3 (2000), 199-253.

[112] Hochsmann, M., Toller, T., Giegerich, R., And Kurtz, S. Local similarity in RNA secondary structures. Proceedings of the Computational Systems Bioinformatics (CSB 2003) (2003), 159-168.

[113] Hochsmann, M., Voss, B., And Giegerich, R. Pure multiple RNA secondary structure alignments: a progressive profile approach. IEEE Transactions on Computational Biology and Bioinformatics 1, 1 (2004), 53-62.

[114] Hofacker, I. L. Vienna RNA secondary structure server. Nucleic Acids Research 31, 13 (2003), 3429-3431.

[115] Hofacker, I. L., Benhart, S. H. F., And Stadler, P. F. Alignment of RNA base pairing probability matrices. Bioinformatics 20, 14 (2004), 2222-2227.

[116] Hofacker, I. L., Fekete, M., and Stadler, P. F. Secondary structure prediction for aligned RNA sequences. Journal of Molecular Biology 319 (2002), 1059-1066.

[117] Hofacker, I. L., Fontana, W., Stadler, P. F., Bonhoeffer, L. S., Tacker, M., AND Schuster, P. Fast folding and comparison of RNA secondary structures. Monatshefte fur Chemie 125 (1994), 167-188.

[118] Holmes, I. Accelerated probabilistic inference of RNA struture evolution. BMC Bioinformatics 6, 73 (2005). doi:10.1186/1471-2105-6-73. 
[119] Holmes, I., And Rubin, G. M. Pairwise RNA structure comparison with SCFGs. Pacif Symposium on Biocomputing (2002), 163-174.

[120] Huttenhofer, A., Schattner, P., And Polacek, N. Non-coding RNAs: hope or hype? Trends in Genetics 21, 5 (2005), 289-297.

[121] Imamura, T., Yamamoto, S., Ohgane, J., Hattori, N., Tanaka, S., and Shiota, K. Non-coding RNA directed DNA demethylation of Sphk1 CpG island. Biochemical and Biophysical Research Communications 322, 2 (2004), 593-600.

[122] INFERNAL User's Guide, 2005. ftp://ftp.genetics.wustl.edu/pub/eddy/software/ infernal/Userguide.pdf.

[123] Iribar, M. P., Tosi, L. R., ANd Cruz, A. K. A processed short transcript of Leishmania, ODD1. Molecular \& Biochemical Parasitology 127 (2003), 205-208.

[124] Ishit, N., Ozaki, K., Sato, H., Mizuno, H., Susumu, S., Takahashi, A., Miyamoto, Y., Ikegawa, S., Kamatani, N., Hori, M., Satoshi, S., Nakamura, Y., and Tanaka, T. Identification of a novel non-coding RNA, MIAT, that confers risk of myocardial infarction. Journal of Human Genetics (2006). doi:10.1007/s10038-006-0070-9.

[125] Plasmodium vivax Genome Project. http://www.tigr.org/tdb/e2k1/pva1/.

[126] Abbreviations and symbols for nucleic acids, polynucleotides and their constituents - Commission on Biochemical Nomenclature (CBN). http://www.mun.ca/biochem/courses/3107/symbols.html.

[127] Jacob, F., And Monod, J. Genetic regulatory mechanisms in the sysnthesis of proteins. Journal of Molecular Biology 3 (1961), 318-356.

[128] James, B. D., Olsen, G. J., And Pace, N. R. Phylogenetic comparative analysis of RNA secondary structure. Methods in Enzymology 180 (1989), 227-239.

[129] Ji, Y., Xu, X., And Stormo, G. D. A graph theoretical approach for predicting common RNA secondary structure motifs including psudoknots in unaligned sequences. Bioinformatics 20, 10 (2004), 1591-1602.

[130] Jiang, T., Lin, G., Ma, B., And Zhang, K. A general edit distance between RNA structures. Journal of Computational Biology 9 (2002), 371-388. 
[131] Jiang, T., Wang, L., And Zhang, K. Alignment of trees - an alternative to tree edit. Theoretical Computer Science 143 (1995), 137-148.

[132] JuAn, V., AND Wilson, C. RNA secondary structure prediction based on free energy and phylogenetic analysis. Journal of Molecular Biology 289 (1999), 935-947.

[133] Karlin, S., And Altschul, S. F. Methods for assessing the statistical significance of molecular sequence features by using general scoring schemes. Proceedings of the National Academy of Sciences 87 (1990), 2264-2268.

[134] Karlin, S., Dembo, A., and Kawabata, T. Statistical composition of high-scoring segments from molecular sequences. The Annals of Statistics 18, 2 (1990), 571-581.

[135] Kashimabara, A. Y., Vieira, D. C. G., Machado-lima, A., and Durham, A. M. Splice site prediction using stochastic regular grammars. To appear in Genetics and Molecular Research (2007).

[136] Keenan, R. J., Freymann, D. M., Stroud, R. M., and Walter, P. The signal recognition particle. Annual Review of Biochemistry 70 (2001), 755-775.

[137] Kim, N. W., Piatyszek, M. A., Prowse, K. R., Harley, C. B., West, M. D., Ho, P. L. C., Coviello, G. M., Wright, W. E., Weinrich, S. L., and Shay, J. W. Specific association of human telomerase activity with immortal cells and cancer. Science 266 (1994), 2011-2015.

[138] Klein, R. J., AND EDdy, S. R. RSEARCH: finding homologs of single structured RNA sequences. BMC Bioinformatics 4, 1 (2003), 44.

[139] Klein, R. J., Misulovin, Z., And Eddy, S. E. Noncoding RNA genes identified in AT-rich hyperthermophiles. Proceedings of the National Academy of Sciences 99, 11 (2002), 7542-7547.

[140] Knight, R., Birmingham, A., And Yarus, M. BayesFold: rational $2^{o}$ folds that combine thermodynamic, covariation, and chemical data for aligned RNA sequences. RNA 10 (2004), $1323-1336$.

[141] Knudsen, B., And Hein, J. RNA secondary structure prediction using stochastic contextfree grammars and evolutionary history. Bioinformatics 15, 6 (1999), 446-454.

[142] Knudsen, B., And Hein, J. Pfold: RNA secondary structure prediction using stochastic context-free grammars. Nucleic Acids Research 31, 13 (2003), 3423-3428. 
[143] Korf, I., Yandell, M., And Bedell, J. BLAST. O’Reilly, 2003.

[144] Krogh, A., Brown, M., Mian, I. S., Sjolander, K., And Haussler, D. Hidden markov models in computational biology - applications to protein modeling. Journal of Molecular Biology 235 (1994), 1501-1531.

[145] Kuwabara, T., Hsieh, J., Nakashima, K., Taira, K., and Gage, F. H. A small modulatory dsRNA specifies the fate of adult neural stem cells. Cell 116, 6 (2004), 779-793.

[146] Kwek, K. Y., Murphy, S., Furger, A., Thomas, B., O’Gorman, W., Kimura, H., Proudfoot, N. J., And Akoulitchev, A. U1 snRNA associates with TFIIH and regulates transcriptional initiation. Nature Structural Biology 9 (2002), 800-805.

[147] Lagos-Quintana, M., Rauhut, R., Lendeckel, W., and Tuschl, T. Identification of novel genes coding for small expressed RNAs. Science 294 (2001), 853-858.

[148] Lagos-Quintana, M., Rauhut, R., Yalcin, A., Meyer, J., Lendeckel, W., And Tuschl, T. Identification of tissue-specific microRNAs from mouse. Current Biology 12 (2002), 735-739.

[149] Lai, E. C., Tomancak, P., Williams, R. W., and Rubin, G. M. Computational identification of Drosophila microRNA genes. Genome Biology 4 (2003), R42.1-R42.20.

[150] Lanz, R. B., McKenna, N. J., Onate, S. A., Albrecht, U., Wong, J., Tsai, S. Y., Tsai, M. J., And O’Malley, B. W. A steroid receptor coactivator, SRA, functions as an RNA and is present in an SRC-1 complex. Cell 97, 1 (1999), 17-27.

[151] Laslett, D., And Canback, B. ARAGORN, a program to detect tRNA genes and tmRNA genes in nucleotide sequences. Nucleic Acids Researchs 32, 1 (2004), 11-16.

[152] Laslett, D., Canback, B., And Andersson, S. BRUCE: a program for the detection of transfer-messenger RNA genes in nucleotide sequences. Nucleic Acids Researchs 30, 15 (2002), $3449-3453$.

[153] Le, S. V., Chen, J. H., Currey, K. M., And Maizel, J. V. J. A program for predicting significant RNA secondary structures. Computer Applications in the Biosciences 4, 1 (1988), $153-159$.

[154] Lee, R. C., Feinbaum, R. L., and Ambros, V. The C. elegans heterochronic gene lin-4 encodes small RNAs with antisense complementary with lin-14. Cell 75 (1993), 843-854. 
[155] Leeper, T. C., And Varani, G. The structure of an enzyme-activating fragment of human telomerase RNA. RNA 11, 4 (2005), 394-403.

[156] Lim, L. P., Lau, N. C., Weinstein, E. G., Abdelhakim, A., Yekta, S., Rhoades, M. W., Burge, C. B., And BArtel, D. P. The microRnAs of Caenorhabditis elegans. Genes \&S Development 17 (2003), 991-1008.

[157] Lin, J., Ly, H., Hussain, A., Abraham, M., Pearl, S., Tzfati, Y., Parslow, T. G., AND Blackburn, E. H. A universal telomerase RNA core structure includes structured motifs required for binding the telomerase reverse transcriptase protein. Proceedings of the National Academy of Sciences 101, 41 (2004), 14713-14718.

[158] Lingner, J., Hendrick, L. L., And Cech, T. R. Telomerase RNAs of different ciliates have a common secondary structure and a permuted template. Genes $\&$ Development 8 (1994), 1984-1998.

[159] Liu, A. Y., Torchia, B. S., Migeon, B. R., And Siliciano, R. F. The human NTT gene: identification of a novel 17-kb noncoding nuclear RNA expressed in activated CD4+ T cells. Genomics 39, 2 (1997), 171-184.

[160] Liu, C., Bai, B., Skogerbo, G., Cai, L., Deng, W., Zhang, Y., Bu, D., Zhao, Y., And Chen, R. NONCODE: an integrated knowledge database of non-coding RNAs. Nucleic Acids Research 33 (2005), D112-D115.

[161] Liu, J., Gough, J., And Rost, B. Distinguishing protein-coding from non-coding RNAs through support vector machines. PLOS Genetics 2, 4 (2006), e29.

[162] Lowe, T. M., AND EDdy, S. R. tRNAscan-SE: a program for improved detection of transfer RNA genes in genomic sequence. Nucleic Acids Research 25, 5 (1997), 955-964.

[163] Lowe, T. M., ANd Eddy, S. R. A computational screen for methylation guide snoRNAs in yeast. Science 283 (1999), 1168-1171.

[164] Lowe, T. M. J. Combining new computational and traditional experimental methods to identify tRNA and snoRNA gene families. Master's thesis, Washington University, 1999.

[165] Luck, R., Graf, S., And Steger, G. ConStruct: a tool for thermodynamic controlled prediction of conserved structure. Nucleic Acids Research 27, 21 (1999), 4208-4217. 
[166] Lukiw, W. J., Handley, P., Wong, L., and Crapper Mclachlan, D. R. BC200 RNA in normal human neocortex, non-alzheimer dementia (NAD), and senile dementia of the alzheimer type (AD). Neurochemical Research 17, 6 (1992), 591-597.

[167] LundBlad, V. DNA ends: maintenance of chromosome termini versus repair of double strand breaks. Mutation Research 451 (2000), 227-240.

[168] Lustig, A. J. Telomerase RNA: a flexible RNA scaffold for telomerase biosynthesis. Current Biology 14 (2004), R565-R567.

[169] Lyngso, R. B., And Pedersen, C. N. RNA pseudoknot prediction in energy-based models. Journal of Computational Biology 7 (2000), 409-427.

[170] Machado-Lima, A. Laboratório de geração de classificadores de seqüências. Master's thesis, Universidade de São Paulo - IME, 2002.

[171] Malaria Foundation International - www.malaria.org.

[172] Martignetti, J. A., And Brosius, J. BC200 RNA: a neural RNA polymerase III product encoded by a monomeric Alu element. Proceedings of the National Academy of Sciences 90 (1993), 11563-11567.

[173] Martinez, W. L., And Martinez, A. R. Computational Statistics Handbook With Matlab. CRC Press, 2001.

[174] Mathews, D. H. Predicting a set of minimal free energy RNA secondary structures common to two sequences. Bioinformatics 21, 10 (2005), 2246-2253.

[175] Mathews, D. H., Disney, M. D., Childs, J. L., Schroeder, S. J., Zuker, M., And TURNER, D. H. Incorporating chemical modification constraints into a dynamic programming algorithm for prediction of RNA secondary structure. Proceedings of the National Academy of Sciences 101, 19 (2004), 7287-7292.

[176] Mathews, D. H., And Turner, D. H. Dynalign: an algorithm for finding the secondary structure common to two RNA sequences. Journal of Molecular Biology 317 (2002), 191-203.

[177] Mattick, J. S., And Makunin, I. V. Non-coding RNA. Human Molecular Genetics 15, 1 (2006), 17-29.

[178] MCCaskill, J. S. The equilibrium partition function and base pair binding probabilities for RNA secondary structure. Biopolymers 29 (1990), 1105-1119. 
[179] McCormick-Graham, M., And Romero, D. P. Ciliate telomerase RNA structutal features. Nucleic Acids Research 23, 7 (1995), 1091-1097.

[180] MCCormick-Graham, M., And Romero, D. P. A single telomerase RNA is sufficient for the synthesis of variable telomeric DNA repeats in ciliates of the genus Paramecium. Molecular And Cellular Biology 16, 4 (1996), 1871-1879.

[181] Meller, V. H., Gordadze, P. R., Park, Y., Chu, X., Stuckenholz, C., Kelley, R. L., And Kuroda, M. I. Ordered assembly of rox RNAs into MSL complexes on the dosage-compensated X chromosome in Drosophila. Current Biology 10 (2000), 136-143.

[182] Melnikova, L., And Georgiev, P. Drosophila telomeres: the non-telomerase alternative. Chromosome Research 13, 5 (2005), 431-441.

[183] Meyer, I. M., And Miklos, I. Co-transcriptional folding is encoded within RNA genes. BMC Molecular Biology 5, 10 (2004). doi:10.1186/1471-2199-5-10.

[184] Militello, K. T., Patel, V., Chessler, A. D., Fisher, J. K., Kasper, J. M., GunaseKERA, A., AND WiRTh, D. F. RNA polymerase II synthesizes antisense RNA in Plasmodium falciparum. RNA 11 (2005).

[185] Millar, J. K., Wilson-Annan, J. C., Anderson, S., Christie, S., Taylor, M. S., Semple, C. A., Devon, R. S., Clair, D. M., Muir, W. J., Blackwood, D. H., And Porteous, D. J. Disruption of two novel genes by a translocation co-segregating with schizophrenia. Human Molecular Genetics 9, 9 (2000), 1415-1423.

[186] Missal, K., Zhu, X., Rose, D., Deng, W., Skogerbo, G., Chen, R., And Stadler, P. F. Prediction of structured non-coding RNAs in the genomes of the nematodes Caenorhabditis elegans and Caenorhabditis briggsae. Journal of Experimental Zoology (Mol Dev Evol.) 306, 4 (2006), 379-392.

[187] Moulton, V. Tracking down noncoding RNAs. Proceedings of the National Academy of Sciences 102, 7 (2005), 2269-2270.

[188] Mount, D. W. Bioinformatics - Sequence and genome analysis. Cold Spring Harbor Laboratory Press, 2001.

[189] Nagai, K., Oubridge, C., Kuglstatter, A., Menichelli, E., Isel, C., And Jovine, L. Structure, function and evolution of the signal recognition particle. EMBO Journal 22 (2003), 3479-3485. 
[190] Nam, J. W., Kim, J., Kim, S. K., and Zhang, B. T. ProMIR II: a web server for the probabilistic prediction of clustered, nonclustered, conserved and nonconserved microRNAs. Nucleic Acids Research 34 (2006), 455-458.

[191] NCBI. National Center for Biotechnology Information. http: //www.ncbi.nlm.nih.gov.

[192] Ncbi-blast. http://www.ncbi.nlm.nih.gov/blast/.

[193] Notredame, C., Brien, E. A. O., And Higgins, D. G. RAGA: RNA sequence alignment by genetic algorithm. Nucleic Acids Research 25, 22 (1997), 4570-4580.

[194] Notredame, C., Higgins, D. G., And Heringa, J. T-Coffee: A novel method for fast and accurate multiple sequence alignment. Journal of Molecular Biology 302, 1 (2000), 205-217.

[195] Nussinov, R., Pieczenik, G., Griggs, J. R., and Kleitman, D. J. Algorithms for loop matchings. SIAM Journal on Applied Mathematics 35, 1 (1978), 68-82.

[196] O'Connor, C. M., Lai, C. K., And Collins, K. Two purified domains of telomerase reverse transcriptase reconstitute sequence-specific interactions with RNA. The Journal of Biological Chemistry 280(17):17533-9, 17 (2005), 17533-17539.

[197] Omer, A. D., Lowe, T. M., Russel, A. G., Ebhardt, H., Eddy, S. R., and Dennis, P. P. Homologs of small nucleolar RNAs in Archea. Science 288 (2000), 517-522.

[198] Osborne, R. J., And Thornton, C. A. RNA-dominant diseases. Human Molecular Genetics 15, 2 (2006), 162-169.

[199] Pavesi, A., Conterio, F., Bolchi, A., Dieci, G., and Ottonello, S. Identification of new eukaryotic tRNA genes in genomic DNA databases by a multistep weight matrix analysis of transcriptional control regions. Nucleic Acids Research 22, 7 (1994), 1247-1256.

[200] PCR Glossary - http://www.changbioscience.com/primo/pcr/eprimersdimmer.htm.

[201] Pedersen, J. S., Meyer, I. M., Forsberg, R., Simmonds, P., And Hein, J. A comparative method for finding and folding RNA secondary structures withing protein-coding regions. Nucleic Acids Research 32, 16 (2004), 4925-4936.

[202] Perriquet, O., Touzet, H., and Dauchet, M. Finding the common structure shared by two homologous RNAs. Bioinformatics 19, 1 (2003), 108-116. 
[203] P. falciparum gene models. http://www.plasmodb.org/download/release5.0/Pfalciparum/PfalciparumGeneModels_plasmoDB-5.0.gff.

[204] Piccinelli, P., Rosenblad, M. A., And Samuelsson, T. Identification and analysis of ribonuclease $\mathrm{P}$ and MRP RNA in a broad range of eukaryotes. Nucleic Acids Research 33, 14 (2005), 4485-4495.

[205] Pipas, J. M., And McMahon, J. E. Method for predicting RNA secondary structure. Proceedings of the National Academy of Sciences 72, 6 (1975), 2017-2021.

[206] Pirrit, L. A. Caracterização dos telômeros e da telomerase de Plasmodium falciparum. Tese de Doutorado. Universidade de São Paulo - ICB, 1999.

[207] Polesskaya, O. O., Haroutunian, V., Davis, K. L., Hernandez, I., and Sokolov, B. P. Novel putative nonprotein-coding RNA gene from 11q14 displays decreased expression in brains of patients with schizophrenia. Journal of Neuroscience Research 74 (2003), 111-122.

[208] Raj, D. K., Das, B. R., Dash, A. P., and Supakar, P. C. Identification of telomerase activity in gametocytes of Plasmodium falciparum. Biochemical and Biophysical Research Communications 309 (2003), 685-688.

[209] Ralph, S. A., Bischoff, E., Mittei, D., Sismeiro, O., Dillies, M. A., Guigon, G., Coppee, J. Y., David, P. H., And Scherf, A. Transcriptome analysis of antigenic variation in Plasmodium falciparum - var silencing is not dependent on antisense RNA. Genome Biology 6, 11 (2005), R93.

[210] Reeder, J., And Giegerich, R. Design, implementation and evaluation of a practical pseudoknot folding algorithm based on thermodynamics. BMC Bioinformatics 5, 104 (2004).

[211] Reeder, J., Hochsmann, M., Rehmsmeier, M., Voss, B., And Giegerich, R. Beyond mfold: recent advances in RNA bioinformatics. Journal of Biotechnology 124, 1 (2006), 41-55.

[212] Regalia, M., Rosenblad, M. A., and Samuelsson, T. Prediction of signal recognition particle RNA genes. Nucleic Acids Researc 30, 15 (2002), 3368-3377.

[213] Reis, E. M., Louro, R., Nakaya, H. I., and Verjovski-Almeida, S. As antisense RNA gets intronic. OMICS 9, 1 (2005), 2-12.

[214] Reis, E. M., Nakaya, H. I., Louro, R., Canavez, F. C., Flatschart, A. V., Almeida, G. T., Egidio, C. M., Paquola, A. C., Machado, A. A., Festa, F., Yamamoto, D., 
Alvarenga, R., da Silva, C. C., Brito, G. C., Simon, S. D., Moreira-Filho, C. A., Leite, K. R., Camara-lopes, L. H., Campos, F. S., Gimba, E., Vignal, G. M., El-Dorry, H., Sogayar, M. C., Barcinski, M. A., da Silva, A. M., And VerjovskiAlmeIDA, S. Antisense intronic non-coding RNA levels correlate to the degree of tumor differentiation in prostate cancer. Oncogene 23, 39 (2004), 6684-6692.

[215] Ren, J., Rastegari, B., Condon, A., And Hoos, H. HotKnots: Heuristic prediciton of RNA secondary structures including pseudoknots. RNA 11 (2005), 1419-1504.

[216] Rhodes, D., Fairall, L., Simonsson, T., Court, R., and Chapman, L. Telomere architecture. EMBO reports 3, 12 (2002), 1139-1145.

[217] Rivas, E. Evolutionary models for insertions and deletions in a probabilistic modeling framework. BMC Bioinformatics 6 (2005), 63 .

[218] Rivas, E., AND EDdy, S. R. A dynamic programming algorithm for RNA structure prediction including pseudoknots. Journal of Molecular Biology 285 (1999), 2053-2068.

[219] Rivas, E., ANd Eddy, S. R. Secondary structure alone is generally not statistically significant for the detection of noncoding RNAs. Bioinformatics 16, 7 (2000), 583-605.

[220] Rivas, E., ANd Eddy, S. R. Noncoding RNA gene detection using comparative sequence analysis. BMC Bioinformatics 2, 1 (2001), 8.

[221] Rogaev, E. I. Small RNAs in human brain development and disorders. Biochemistry (Moscow) 70, 12 (2005), 1404-1407.

[222] Romero, D. P., And Blackburn, E. H. A conserved secondary structure for telomerase RNA. Cell 67 (1991), 343-353.

[223] Rosenblad, M. A., Gorodkin, J., Knudsen, B., Zwieb, C., and Samuelsson, T. SRPDB: Signal Recognition Particle Database. Nucleic Acids Research 31, 1 (2003), 363-364.

[224] Rosenblad, M. A., Zwieb, C., And Samuelsson, T. Identification and comparative analysis of components from the signal recognition particle in protozoa and fungi. $B M C$ Genomics 5, 1 (2004), 5 .

[225] Ruan, J., Stormo, G. D., And Zhang, W. ILM: a web server for predicting RNA secondary structures with pseudoknots. Nucleic Acids Research 32, Web Server issue (2004), W146W149. 
[226] Ruan, J., Stormo, G. D., And Zhang, W. An iterated loop matching approach to the prediction of RNA secondary structures with pseudoknots. Bioinformatic 20, 1 (2004), 58-66.

[227] Sakakibara, Y. Grammatical inference in bioinformatics. IEEE Transactions on Pattern Analysis and Machine Intelligence 27, 7 (2005), 1051-1062.

[228] Sakakibara, Y., And Brown, M. The application of stochastic context-free grammars to folding, aligning and modeling homologous RNA sequences. Techn. Rep. UCSC-CRL-94-14.

[229] Sakakibara, Y., Brown, M., Hughey, R., Mian, I. S., Sjolander, K., Underwood, R. C., And Haussler, D. Recents Methods for RNA Modeling Using Stochastic ContextFree Grammars. In Proceedings of the Asilomar Conference on Combinatorial Pattern Matching (1994).

[230] Sakakibara, Y., Brown, M., Hughey, R., Mian, I. S., Sjolander, K., Underwood, R. C., And Haussler, D. Stochastic context-free grammars for tRNA modeling. Nucleic Acids Research (1994), 5112-5120.

[231] Sakakibara, Y., Brown, M., Underwood, R. C., Mian, I. S., and Haussler, D. Stochastic context-free grammars for modeling RNA. Techn.Rep. UCSC-CRL-93-16.

[232] Saldanha, R., Mohr, G., Belfort, M., And Lambowitz, A. M. Group I and group II introns. The FASEB Journal 7 (1993), 15-24.

[233] The Wellcome Trust Sanger Institute. http://www.sanger.ac.uk/.

[234] Sankoff, D. Simultaneous solution of the RNA folding, alignment and protosequence problems. SIAM Journal on Applied Mathematics 45, 5 (1985), 810-825.

[235] Schattner, P. Searching for RNA genes using base-composition statistics. Nucleic Acids Research 30, 9 (2002), 2076-2082.

[236] Schattner, P., Brooks, A. N., And Lowe, T. M. The tRNAscan-SE, snoscan and snoGPS web servers for the detection of tRNAs and snoRNAs. Nucleic Acids Researchs 33 (2005), 686-689.

[237] Schattner, P., Decatur, W. A., Davis, C. A., Ares, M. J., Fournier, M. J., And Lowe, T. M. Genome-wide searching for pseudouridylation guide snoRNAs: analysis of Saccharomyces cerevisiae genome. Nucleic Acids Researc 32, 14 (2004), 4281-4296. 
[238] Scherf, A., Figueiredo, L. M., And Freitas-Junior, L. H. Plasmodium telomeres: a pathogen's perspective. Current Opinion in Microbiology 4 (2001), 409-414.

[239] Scherthan, H. A bouquet makes ends meet. Molecular Cell Biology 2 (2001), 621-627.

[240] Schmitz, M., And Steger, G. Description of RNA folding by simulated annealing. Journal of Molecular Biology 255 (1996), 254-266.

[241] Schuster, P., Stadler, P. F., And Renner, A. RNA structures and folding: from conventional to new issues in structure predictions. Current Opinion in Structural Biology 7, 2 (1997), 229-235.

[242] Sczyrba, A., Kruger, J., Mersch, H., Kurtz, S., And Giegerich, R. RNA-related tools on the Bielefeld bioinformatics server. Nucleic Acids Research 31, 13 (2003), 3767-3770.

[243] Searls, D. The linguistics of DNA. American Scientist 80 (1992), 579-591.

[244] Searls, D. Linguistic approaches to biological sequences. Computer Applications in the Biosciences 13, 4 (1997), 333-344.

[245] Searls, D. Formal language theory and biological macromolecules. Series in Discrete Mathematics and Theoretical Computer Science 47 (1999), 117-140.

[246] Searls, D. B. The language of genes. Nature 420 (2002), 211-217.

[247] Shapiro, B. A., And Zhang, K. Comparing multiple RNA secondary structures using tree comparisons. Computer Applications in the Biosciences 6, 4 (1990), 309-318.

[248] Siebert, S., And Backofen, R. MARNA: multiple alignment and consensus structure prediction of RNAs based on sequence structure comparisons. Bioinformatics 21, 16 (2005), $3352-3359$.

[249] Sleutels, F., Zwart, R., And Barlow, D. P. The non-coding Air RNA is required for silencing autosomal imprinted genes. Nature 415, 6873 (2000), 810-813.

[250] Sperling, L., Dessen, P., Zagulski, M., Pearlman, R. E., Migdalski, A., Gromadka, R., Froissard, M., Keller, A. M., And Cohen, J. Random sequencing of Paramecium somatic DNA. Eukaryotic Cell 1, 3 (2002), 341-352.

[251] Sprinzl, M., Horn, C., Brown, M., Ioudovitch, A., And Steinberg, S. Compilation of tRNA sequences and sequences of tRNA genes. Nucleic Acids Research 26, 1 (1998), 148153. 
[252] Steffen, P., Voss, B., Rehmsmeier, M., Reeder, J., And Giegerich, R. RNAshapes: an integrated RNA analysis package based on abstract shapes. Bioinformatics 22, 4 (2006), $500-503$.

[253] Stoeckert, C. J. J., Fischer, S., Kissinger, J. C., Heiges, M., Aurrecoechea, C., Gajria, B., And Roos, D. S. PlasmoDB v5: new looks, new genomes. Trends in Parasitology (2006). doi:10.1016/j.pt.2006.09.005.

[254] Storz, G. An expandind universe of noncoding RNAs. Science 296 (2002), 1260-1263.

[255] Storz, G., Altuvia, S., and Wassarman, K. M. An abundance of RNA regulators. Annual Review of Biochemistry 74 (2005), 199-217.

[256] Stricklin, S. L. Noncoding RNA genes in Caenorhabditis elegans, 2006. Ph.D. Thesis.

[257] Stricklin, S. L., Griffiths-Jones, S., And Eddy, S. R. C. elegans Noncoding RNA Genes. In WormBook. ed. The C. elegans Research Community, WormBook, doi/10.1895/wormbook.1.7.1, http://www.wormbook.org, 2005.

[258] Tabaska, J. E., Cary, R. B., Gabow, H. N., and Stormo, G. D. An RNA folding method capable of identifying pseudoknots and base triples. Bioinformatics 14, 8 (1998), 691-699.

[259] Tam, W., Ben-Yehuda, D., And HaYward, W. bic, a novel gene activated by proviral insertions in avian leukosis virus-induced lymphomas, is likely to function through its noncoding RNA. Molecular and Cellular Biology 17, 3 (1997), 1490-1502.

[260] TAneda, A. Cofolga: a genetic algotithm for finding the common folding of two RNAs. Computational Biology and Chemistry 29 (2005), 111-119.

[261] ten Dam, E., van Belkum, A., And PleiJ, K. A conserved pseudoknot in telomerase RNA. Nucleic Acids Research 19, 24 (1991), 6951.

[262] The VFLib Graph Matching Library. http://amalfi.dis.unina.it/graph/db/vflib2.0/doc/vflib.html.

[263] The Institute for Genomic Research. http://www.tigr.org/.

[264] Tinoco, I. J., Uhlenbeck, O. C., And Levine, M. D. Estimation of secondary structure in ribonucleic acids. Nature 230, 5293 (1971), 362-367. 
[265] Torres-larios, A., Swinger, K. K., Krasilnikov, A. S., Pan, T., and Mondragon, A. Crystal structure of the RNA component of bacterial ribonuclease P. Nature 437, 7058 (2005), 584-587.

[266] Touzet, H., And Perriquet, O. CARNAC: folding families of related RNAs. Nucleic Acids Research 32 (2004), W142-W145.

[267] Turner, D. H., And Sugimoto, N. RNA structure prediction. Annual Review of Biophysics and Biophysical Chemistry 17 (1988), 167-192.

[268] Tzfati, Y., Knight, Z., Roy, J., And Blackburn, E. H. A novel pseudoknot element is essential for the action of a yeast telomerase. Genes \& Development 17, 14 (2003), 1779-1788.

[269] Ueda, C. T., And Roberts, R. W. Analysis of a long-range interaction between conserved domains of human telomerase RNA. RNA 10, 1 (2004), 139-147.

[270] Ullmann, J. R. An algorithm for subgraph isomorphism. Journal of the Assoc. for Computing Machinery 23 (1976), 31-42.

[271] Underwood, R. C. Stochastic Context-Free Grammars for Modeling Three Spliceosomal Small Nuclear Ribonucleic Acids. Master's thesis, Baskin Center for Computer Engineering and Information Sciences, University of California, 1994.

[272] Uzilov, A. V., Keegan, J. M., And Mathews, D. H. Detection of non-coding RNAs on the basis of predicted secondary structure formation free energy change. BMC Bioinformatics 7 (2006). doi:10.1186/1417-2105-7-173.

[273] VAladkhan, S. snRNAs as the catalysts of pre-mRNA splicing. Current Opinion in Chemical Biology 9 (2005), 603-608.

[274] van Zon, A., Mossink, M. H., Scheper, R. J., Sonneveld, P., And Wiemer, E. A. The vault complex. Cell Molecular Life Sciences 60 (2003), 1828-1837.

[275] Velleca, M. A., Wallace, M. C., And Merlie, J. P. A novel synapse-associated noncoding RNA. Molecular and Cellular Biology 14, 11 (1994), 7095-7104.

[276] Voss, B., Giegerich, R., And Rehmsmeier, M. Complete probabilistic analysis of RNA shapes. BMC Biology 4, 5 (2006).

[277] Wang, C., Ding, C., Meraz, R. F., And Holbrook, S. R. PSoL: a Positive Sample only Learning algorithm for finding ncRNA genes. Bioinformatics 22, 21 (2006), 2590-2596. 
[278] Wang, C., Le, S. Y., Ali, N., And Siddiqui, A. An RNA pseudoknot is an essential structural element of the internal ribosome entry site located within the hepatitis $\mathrm{C}$ virus 5' noncoding region. $R N A 1$ (1995), 526-537.

[279] Wang, X., Zhang, J., Li, F., Gu, J., He, T., Zhang, X., And Li, Y. MicroRnA identification based on sequence and structure alignment. Bioinformatics 21, 18 (2005), 36103614 .

[280] Washiet, S., AND Hofacker, I. L. Consensus folding of aligned sequences as a new measure for the detection of functional RNAs by comparative genomics. Journal of Molecular Biology 342 (2004), 19-30.

[281] Washietl, S., Hofacker, I. L., and Stadler, P. F. Fast and reliable prediction of noncoding RNAs. Proceedings of the National Academy of Sciences 102, 7 (2005), 2454-2459.

[282] Wassarman, K. M. RNA regulators of transcription. Nature Structural \&6 Molecular Biology 11,9 (2004), 803-804.

[283] Wassarman, K. M., Zhang, A., And Storz, G. Small RNAs in Escherichia coli. Trends in Microbiology 7 (1999), 37-45.

[284] Waterman, M. S., And Smith, T. F. RNA secondary structure: a complete mathematical analysis. Mathematical Biosciences 42 (1978), 257-266.

[285] Weinberg, Z., And Ruzzo, W. L. Exploiting conserved structure for faster annotation of non-coding RNAs without loss of accuracy. Bioinformatics 20, Suppl 1 (2004), i334-i341.

[286] Weinberg, Z., And Ruzzo, W. L. Sequence-based heuristics for faster annotation of noncoding RNA families. Bioinformatics 22, 1 (2006), 35-39.

[287] Weinert, T., And Lundblad, V. Forever hopeful relations: chromatin, telomeres and checkpoints. Nature genetics 21 (1999), 151-152.

[288] Westhof, E. Group I introns and RNA folding. Biochemical Society Transactions 30, 6 (2002), 1149-1152.

[289] Workman, C., And Krogh, A. No evidence that mRNAs have lower foldint free energies than random sequences with the same dinucleotide distribution. Nucleic Acids Research 27, 24 (1999), 4816-4822.

[290] Wu-blast. http://blast.wustl.edu/. 
[291] Wuchty, S., Fontana, W., Hofacker, I. L., and Schuster, P. Complete suboptimal folding of RNA and the stability of secondary structure. Biopolymers 49 (1999), 145-165.

[292] Yang, J. H., Zhang, X. C., Huang, Z. P., Zhou, H., Huang, M. B., Zhang, S., Chen, Y. Q., AND QU, L. H. snoSeeker: an advanced computational package for screening of guide and orphan snoRNA genes in the human genome. Nucleic Acids Researc (2006). doi:10.1093/nar/gkl672.

[293] Yang, Z., Zhu, Q., Luo, K., And Zhou, Q. The 7SK small nuclear RNA inhibits the CDK9/cyclin T1 kinase to control transcription. Nature 414 (2001), 317-322.

[294] Ye, A. J., And Romero, D. P. Phylogenetic relationships amongst tetrahymenine ciliates inferred by a comparison of telomerase RNAs. International Journal of Systematic and Evolutionary Microbiology 52 (2002), 2297-2302.

[295] Ying, X., Luo, H., Luo, J., And LI, W. RDfolder: a web server for prediction of RNA secondary structure. Nucleic Acids Research 32, Web Server issue (2004), W150-W153.

[296] Yu, Y. K., Wootton, J. C., And Altschul, S. F. The compositional adjustment of amino acid substitution matrices. Proceedings of the National Academy of Sciences 100, 26 (2003), 15688-15693.

[297] Zalfa, F., Giorgi, M., Primerano, B., Moro, A., Di Penta, A., Reis, S., Oostra, B., And BAGnI, C. The fragile X syndrome protein FMRP associates with BC1 RNA and regulates the translation of specific mRNAs at synapses. Cell 112 (2003), 317-327.

[298] Zappulla, D. C., And CeCh, T. R. Yeast telomerase RNA: a flexible scaffold for protein subunits. Proceedings of the National Academy of Sciences 101, 27 (2004), 10024-10029.

[299] Zuker, M. On finding all suboptimal foldings of an RNA molecule. Science 244 (1989), $48-52$.

[300] Zuker, M. Mfold web server for nucleic acid folding and hybridization prediction. Nucleic Acids Research 31, 13 (2003), 3406-3415.

[301] Zuker, M., Mathews, D. H., And Turner, D. H. Algorithms and thermodynamics for RNA secondary structure prediction: A practical guide. RNA Biochemistry and Biotechnology (1999), 11-43.

[302] Zuker, M., And Stiegler, P. Optimal computer folding of large RNA sequences using thermodynamics and auxiliary information. Nucleic Acids Research 9, 1 (1981), 133-148. 